Cecilia Pessoa Rodrigues

Interações entre células dendríticas, mastócitos e células tumorais.

Dissertação apresentada ao Programa de Pós-Graduação em Imunologia do Instituto de Ciências Biomédicas da Universidade de São Paulo para obtenção de Título de Mestre em Ciências 
Cecilia Pessoa Rodrigues

\section{Interações entre células dendríticas, mastócitos e células tumorais.}

Dissertação apresentada ao Programa de PósGraduação em Imunologia do Instituto de Ciências Biomédicas da Universidade de São Paulo para obtenção de Título de Mestre em Ciências Área de concentração: Imunologia

Orientador: Prof. Dr. José Alexandre Marzagão Barbuto

Versão Corrigida. A versão original eletrônica encontra-se disponível tanto na Bibliotrca do ICB quanto na Biblioteca Digital de Teses e Dissertações da USP (BDTD) 
DADOS DE CATALOGAÇÃo NA PUBLICAÇÃO (CIP)

Serviço de Biblioteca e Informação Biomédica do

Instituto de Ciências Biomédicas da Universidade de São Paulo

reprodução não autorizada pelo autor

Rodrigues, Cecilia Pessoa.

Interações entre células dendríticas, mastócitos e células tumorais / Cecilia Pessoa Rodrigues. -- São Paulo, 2015.

Orientador: Prof. Dr. José Alexandre Marzagão Barbuto.

Dissertação (Mestrado) - Universidade de São Paulo. Instituto de Ciências Biomédicas. Departamento de Imunologia. Área de concentração: Imunologia. Linha de pesquisa: Imunologia de Tumores.

Versão do título para o inglês: Dendritic, mast and tumor cells interaction.

1. Células Dendríticas 2. Mastócitos 3. Microambiente tumoral 4. PD-1. I. Barbuto,Prof. Dr. José Alexandre Marzagão II. Universidade de São Paulo. Instituto de Ciências Biomédicas. Programa de PósGraduação em Imunologia III. Título. 
UNIVERSIDADE DE SÃO PAULO

INSTITUTO DE CIÊNCIAS BIOMÉDICAS

Candidato(a):

Título da Dissertação

Orientador(a):

\section{Cecilia Pessoa Rodrigues.}

Interações entre células dendríticas, mastócitos e células tumorais.

A Comissão Julgadora dos trabalhos de Defesa da Dissertação de Mestrado, em sessão pública realizada a considerou

\section{( ) Aprovado(a) \\ ( ) Reprovado(a)}

Examinador(a): Assinatura:

Nome:

Instituição:

Examinador(a): Assinatura:

Nome:

Instituição:

Presidente: Assinatura:

Nome:

Instituição: 
São Paulo, 17 de maio de 2013.

\section{PARECER 1111/CEP}

A Comissão de Ética em Pesquisas em Seres Humanos do ICB, na sessão realizada no dia 08.05.013, APROvou o projeto intitulado: "Interações entre células dendríticas, mastócitos e células tumorais" do pesquisador JosÉ ALEXANDRE MARZAGÃo BARbuto e aluna Cecilia Pessoa Rodrigues ".

Cabe aos Pesquisadores executantes elaborar e apresentar a este Comitê, relatórios anuais (parciais ou final ), de acordo com a resolução 196/06 do Conselho Nacional da Saúde, item IX. 2 letra c. conforme modelo constante no site.icb.usp.br.

Ao pesquisador cabe também finalizar o processo junto à Plataforma Brasil quando do encerramento deste.

O primeiro relatório deverá ser encaminhado à Secretaria deste CEP em 08.05.2014.

Atenciosamente,

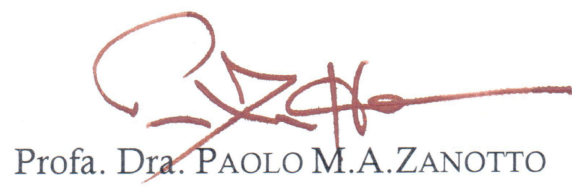

Coordenador da Comissão de Ética em

Pesquisas com Seres Humanos - ICB/USP 
Aos meus pais, Elda e Marino, por toda paciência e apoio. 


\section{Agradecimentos}

Aos meus pais pelo amor incondicional, por sempre garantir as possibilidades para eu seguir meus sonhos, até os mais impossíveis como ir pra lua! Obrigada, por me ensinar que com dedicação e muito trabalho tudo se torna possível, ok, quase tudo.

Aos meus familiares, principalmente minhas avós (in memoriam) e "tias", que em todos os momentos de minha formação educacional me apoiaram.

Ao meu orientador, Prof. Dr. José Alexandre Marzagão Barbuto, por ter concedido a oportunidade de conviver dois anos sob sua orientação, por ter acreditado na minha ideia, por compartilhar seus "delírios imunológicos" e, principalmente, por me mostrar que ainda existem pesquisadores movidos pela curiosidade e vontade de ajudar o próximo.

Aos professores Dra. Karina Salmazi, Dr. Alexandre Steiner, Dr. Niels Olsen pelas críticas e sugestões durante exame de qualificação.

Aos meus companheiros de laboratório, atuais e passados; Ana Carolina, Ariane, Bruna, Célia, Claudinha, Cristiano, Kleber, Karen, Isabella, Lucila, Maria, Mariana, Patty Bergami, Ricardo, Roberto, Rodrigo, Sarah, Salomão e Thiago, sempre dispostos a ajudar.

Em especial, agradeço, o Cristiano Jacob (Cris) e Roberto Gonzalez, que me acolheram assim que cheguei e me ensinaram a rotina do laboratório. À Ana Carolina Franco Ferreira (Ana), por todos os ensinamentos e discussões. Os colegas, Bruna Zelante, Mariana Pinho, Karen Steponavicius, Kleber Ferreira, Maria Alejandra Salomon e Rodrigo Ramos, por todas as discussões, conselhos e auxílios experimentais. Mas, acima disso agradeço por terem deixado um pouquinho de vocês em mim! Ao lado de vocês aprendi tanto questões acadêmicas, quanto pessoais.

Aos demais alunos do departamento, em especial a comissão organizadora do curso de verão.

Às minhas amigas, Lais (Somália), Muriel (Sarninha), Viviane (Pint), Manuela (Taki), Elaine (Ploc), Camila (Pinguim), Marcela (Parenta) e Carolina (Caru). Por sempre colocar meus pés no chão, por cada: "Para de ser besta, Dupexe", por escutar minhas lamúrias e conquistas.

Aos amigos, Jesus, Manuel, Talita (Talit), Talita (Tex), Maira, Mayra, Marina (Nina), Thiago e Letícia, pela torcida!

À todos os professores do departamento de Imunologia pelas aulas ministradas, disponibilização de laboratório e reagentes.

À todos os funcionários do departamento de Imunologia, por serem sempre solícitos e bem humorados, garantindo um ótimo ambiente de trabalho. Em especial, a secretária da PósGraduação, Maria Eni do Sacramento, por sempre responder as nossas dúvidas burocráticas e a Andrea Glatt por toda ajuda nos ensaios de citômetria de fluxo.

Ao banco de sangue do Hospital alemão Oswaldo Cruz, por fornecer as câmaras de leucorredução de doadores saudáveis. Agradeço também, os doadores que concordaram em ajudar a pesquisa. 
Aos funcionários do CEFAP-USP. Em especial, Fernando e Mario, por sempre dispor um horário na agenda para execução dos experimentos de cell sorting e microscopia confocal.

Aos alunos e funcionários do Nucel por todas as discussões.

Ao prof. Dr. Ramon Kaneno por todos os ensinamentos e por fornecer as células da linhagem de câncer colo-retal humano HCT-116

Ao prof. Dr. Joseph Butterfield por fornecer as células de mastocitoma humano.

À FAPESP e CNPq pelo apoio financeiro para o desenvolvimento deste trabalho.

Muito obrigada a todos. 
"Ávido de explicações e novas elucidações, o homem impõe respostas e encontra novas interrogações." 


\section{Resumo}

Rodrigues CP. Interações entre células dendríticas, mastócitos e células tumorais. [dissertação (Mestrado em Imunologia)]. São Paulo: Instituto de Ciências Biomédicas, Universidade de São Paulo; 2015.

O microambiente tumoral (TM) é fator que influencia muito a resposta imune contra tumores. Este é formado por células transformadas, células do sistema imune, componentes vasculares e células mesenquimais. Estas diferentes células podem tem papel benéfico, nocivo ou ambíguo na ação antitumoral, dependendo, novamente, de inúmeros fatores, que vão desde as interações celulares até às citocinas presentes no ambiente. Um exemplo desta ambivalência funcional são as células dendríticas (DCs). Estas, embora capazes de desencadear respostas efetoras efetivas quando são ativadas por sinais de perigo, no microambiente tumoral frequentemente não o fazem. Neste, as DCs são encontradas em um estado imaturo e, portanto, não só não induzem respostas antitumorais efetivas, como podem, até, contribuir para o escape tumoral ao sistema imune. Estudos recentes demonstram que mastócitos (MCs) são células recrutadas para o nicho tumoral e no câncer colo-retal (CCR) foi relatada uma correlação positiva entre o infiltrado de MCs e a progressão de pólipos para CCR. No entanto, não se sabe que efeitos tem a interação MCs-DCs no TM. Assim, o objetivo deste estudo foi investigar os efeitos desta interação sobre DCs. MC foram obtidos a partir da diferenciação in vitro de células $\mathrm{CD} 34^{+}$presentes no sangue humano ou da linhagem de mastocima HMC-1.1. A diferenciação in vitro de MC foi confirmada por citometria de fluxo, em que $91 \pm 2,9 \%$ eram

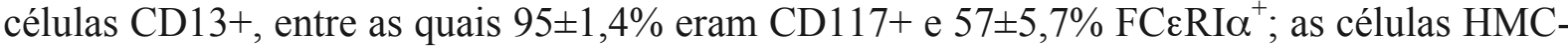
1.1 apresentavam fenótipo semelhante Os MCs diferenciados foram co-cultivados (MCT) ou não (MC) com células de uma linhagem de CCR humano (HCT-116). Após 24h, MCTs foram separadas por FACS, e MCT e MC foram co-cultivadas com iDCs derivadas de monócitos autólogos (iDC-MCT; iDC-MC). iDCs cultivadas separadamente foram usadas como controle. Após 2 dias, avaliou-se o imunofenótipo das DCs que apresentavam diminuição significativa da expressão de HLA-DR (iDC: $33.690 \pm 13.171$; MC: $7.093 \pm 910$; MCT: $8.145 \pm 2.680$ ) e de CD80 (iDC: $473 \pm 150$; MC: $336 \pm 94$; MCT : $247 \pm 38$ ) bem como aumento de PDL1 (iDC: $474 \pm 96$; MC: $623 \pm 104$; MCT: $247 \pm 38$ ). iDC-MC e iDC-MCT estimularam a expressão de FoxP3 por linfócitos T (alogênicos) e menor proliferação do que a induzida por iDCs. Linfócitos estimulados por iDC-MC e iDC-MCT produziam mais IL-10 e TGF- $\beta$ e suprimiram a resposta de linfócitos $\mathrm{T}$ naïve a PHA. Todas estas respostas foram mais intensas quando as células estimuladoras foram as iDC-MCT. Por outro lado, DCs cultivadas em contato com os produtos de secreção de MC (num sistema transwell) apresentaram imunofenótipo de DCs maduras, mesmo sem estímulo externo de maturação, e capacidade de estimular linfócitos T alogênicos equivalente a de iDCs controle. Por fim, as DCs co-cultivadas com HMC-1.1 produziram níveis elevados de indoleamina-2,3deoxigenase (IDO), o que foi bloqueado pelo tratamento das HMC-1.1 com anti-PD-1 ou pelo tratamento de DCs com anti-PD-L1 ou anti-PD-L2, mas não pelo bloqueio de receptores de histamina $\mathrm{H} 1$ e $\mathrm{H} 2$ em DCs. Estes resultados sugerem, portanto, que o infiltrado de MC pode contribuir para o desequilíbrio imunológico encontrado em tumores e que uma melhor caracterização de seu papel pode oferecer novos alvos para prognóstico do câncer ou para intervenções terapêuticas.

Palavras-chaves: Células dendríticas; Mastócitos; Microambiente tumoral; PD-1 


\begin{abstract}
Rodrigues CP. Interactions between dendritic cells, mast cells and tumor cells. [Masters thesis (Immunology)]. São Paulo: Instituto de Ciências Biomédicas, Universidade de São Paulo; 2015.
\end{abstract}

The tumor microenvironment (TM) is a factor that affects significantly the immune response against tumors. It is composed of transformed and immune cells, vascular components and mesenchymal cells. These may have beneficial, harmful or display a dual role in the antitumor reaction. One example of this ambivalence is the dendritic cell (DC). DCs, though able to initiate effective immune response, fail to do so in the TM, since, DCs in the TM are in an immature state (iDC), thus not only failing to induce an anti-tumor response, but even contributing to the tumor evasion. Recent studies demonstrate that cancer cells recruit mast cells (MCs) in early stages of tumor development and in colorectal cancer (CRC) it has been described a positive correlation between MCs infiltration and progression of polypus to CRC. However, the interactions of MCs and DCs in TM have not been elucidated. This study, thus, aims to evaluate MCs role upon DCs functions. MC were obtained from blood CD $34^{+}$after differentiation induced by a specific cytokine cocktail in vitro, MC differentiation was confirmed by flow cytometry, wherein $91 \pm 2,9 \%$ were CD13 cells, among them were $95 \pm 1,4 \% \mathrm{CD} 117^{+}$and $57 \pm 5,7 \% \mathrm{FC}_{\mathrm{RI}} \alpha^{+}$, quite similar to human mast cell lineage HMC-1.1. These were, then, co-cultured (MCT) or not (MC) with CRC cells. After 24h, MCs and MCTs were separated by FACS, and co-cultured with autologous monocyte-derived iDCs (MCTDC; MC-DC). After 2 days, we evaluated the immunephenotype of DCs. In the presence of MCs, DCs had decreased median fluorescent intensity of HLA-DR (iDC: $33.690 \pm 13.171$; MC: $7093 \pm 910$; MCT: $8145 \pm 2680$ ) and CD80 (iDC: $473 \pm 150$; MC: $336 \pm 94$; MCT: 247 \pm 38 ) and increased MFI of PD-L1 (iDC: $474 \pm 96$; MC: $623 \pm 104$; MCT: $247 \pm 38$ ). In addition, MC-DC and MCT-DC induced high levels of FoxP3 expression and down regulated allogeneic T-lymphocytes proliferation, but both were more intense in MCT-DCs. Furthermore, MCT-DC induced stable expression of FoxP3, associated to higher suppression ability and anti-inflammatory IL-10 and TGF- $\beta$ production. It is worth noting that MC secretion products (transwell system) induced a mature DCs surface phenotype, in the absence of other stimulus, and they induced allogeneic $\mathrm{T}$ cells proliferation as iDCs. Besides, DCs, co-cultured with MC, expressed higher levels of indoleamine-2,3,-deoxigenase (IDO), and this was blocked by treatment of HMC-1.1 with anti-PD-1 or by the treatment of DCs with anti-PD-L1 or PD-L2, but the IDO production remained unaffected by blockage of H1 and $\mathrm{H} 2$ histamine receptors on DCs. Therefore, we anticipate that MCs capable to infiltrate CCR may contribute to the immune disequilibrium found in the tumor and, thus, further characterization of their role in this setting may offer new targets for cancer prognosis or therapeutic interventions.

Keywords: Dendritic cells; Mast cells; Tumor microenvironment; PD-1 


\section{Lista de Figuras}

Figura 1. Análise da ausência de Micoplasma sp nas culturas celulares utilizadas no

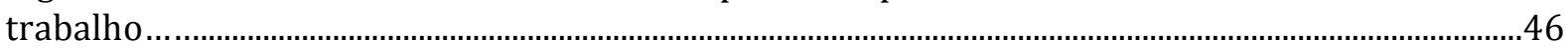

Figura 2. Validação da viabilidade, capacidade de diferenciação e maturação em meio IMDM10

Figura 3. Dot-Plots representativos da separação de células tronco CD34+ por seleção imunomagnética positiva

Figura 4. Fotografia representativa da progressão na diferenciação de CD34+ em MCs.

Figura 5. Fotografias representativas da morfologia de mastócitos (MC) diferenciados in vitro e linhagem de mastocitoma HMC-1.1.

Figura 6. Representação da estratégia de gate empregada para fenotipagem e análise das populações de MCs derivadas da diferenciação in vitro a partir de células CD34+

Figura 7. Comparação morfologia e imunofenotipica de MCs diferenciados in vitro a partir de células CD34+ (MCs) com linhagens de mastocitoma HMC-1.1 e HMC-1.2.

Figura 8. Análise da expressão da molécula CD66 e/a/c (EPICAM 1) pelas células HCT116

Figura 9. Estratégia de gate utilizada no sorting de Mastócitos e HCT-116.

Figura 10. Avaliação da pressão exercida pelo nozzle quanto a viabilidade de células HCT-116, após o sorting.

Figura 11. Avaliação da presença de MCs após o sorting e da interação destas com DCs autólogas

Figura 12. Avaliação do fenótipo após co-cultura em monolayer . .56

Figura 13. Representação da estratégia empregada para a análise dos marcadores em DC.

Figura 14. Gráficos do index intensidade Mediana de Fluorescência (MFI) das células positivas quanto as moléculas de superfície em células dendríticas imaturas (controle), co-cultivadas com mastócito em monolayer (iDC-MC) ou co-cultiva com mastócitos sensibilizados com a linhagem tumoral HCT-116 em monolayer (iDC-MCT)

Figura 15. Avaliação da expressão de moléculas de co-estimulo nas células DCs e MCs.

Figura 16. Avaliação das citocinas peresentes no sobrenadante após dois dias de cocultivo 
Figura 17. Representação gráfica do delineamento experimental.

Figura 18. Gráficos representativos do isolamento de linfócitos por seleção imunomagnética

Figura 19. Capacidade estimuladora de células dendríticas imaturas co-cultivadas ou não com mastócitos

Figura 20. Representação gráfica do resultado da diluição do CFSE

Figura 21. Representação gráfica da frequência de células CD3+ CFSE+/low CD4+ ou CD3+ CFSE+/low CD8+

Figura 22. Representação gráfica da frequência e da intensidade mediana de fluorescência (MFI) das células CD3+ CD4+ CD25+

Figura 23. Representação gráfica do delineamento experimental para a análise da expressão de FoxP3 nas células $\mathrm{T} \quad \mathrm{CD} 4+\mathrm{CD} 25+\quad$ co-cultivadas ou não com mastócitos

Figura 24. Avaliação da expressão de FoxP3 nas células CD3+CD4+CD25+ quando estes linfócitos foram co-cultivados ou não com iDC previamente co-cultivas com mastócitos (nos diferentes grupos experimentais).

Figura 25. Gráfico representativo da expressão de CD127 pelas células CD3+ CD4+ CD25+

Figura 26. Gráfico representativo da expressão de FoxP3 pelas células CD3+ CD4+ CD25+

Figura 27. Gráficos do index intensidade Mediana de Fluorescência (MFI) das células positivas quanto as moléculas de superfície em células dendríticas imaturas (controle), estimuladas com TNF- $\alpha$ (mDC) por 48 horas.

Figura 28. Quantificação das citocinas presentes no sobrenadante da co-cultura de linfócitos T alogênicos imunomagneticamente separados com iDC provenientes dos grupos experimentais

Figura 29. Avaliação da produção de IL-10 por linfócitos T co-cultivas com iDCs dos diferentes grupos experimentais.

Figura 30. Avaliação da produção de TGF- $\beta$ por linfócitos T co-cultivas com iDCs dos diferentes grupos experimentais.

Figura 31. Representação gráfica do delineamento experimental para análise de supressão da proliferação de linfócitos T CD4+ naïve

Figura 32. Avaliação da capacidade supressora dos linfócitos CD3+CD4+ CD25+ oriundos do cocultivo com iDC-MC.

Figura 33. Avaliação da capacidade supressora dos linfócitos CD3+CD4+ CD25+ oriundos do cocultivo com iDC-MCT. 
Figura 34. Representação gráfica da supressão promovida pelos linfócitos CD3+CD4+CD25+ cocultivadas com linfócitos T naïve e estimulados com PHA.

Figura 35. Gráficos do index intensidade Mediana de Fluorescência (MFI) das células positivas quanto as moléculas de superfície em células dendríticas imaturas (iDC) (controle), cocultivadas com mastócito em transwell (iDC/MC), co-cultiva com mastócitos sensibilizados com $\begin{array}{llllll}\text { a linhagem tumoral } & \text { HCT-116 em transwell } & \text { (iDC/MCT)... }\end{array}$

Figura 36. Gráficos do index intensidade Mediana de Fluorescência (MFI) das células positivas quanto as moléculas de superfície em células dendríticas imaturas (iDC) (controle), cocultivadas com mastócito em monolayer (iDC-MC) ou co-cultiva com mastócitos em transwell (iDC/MCT)

Figura 37. Quantificação das citocinas presentes no sobrenadante da cultura de iDC controle (iDC), estimulada com 20\% de sobrenadante de HCT-116 (HCT-116), 20\% do sobrenadante cocultura de mastócito com HCT-116 (SB Co-cultura), 20\% do sobrenadante de Mastócito (SB Mastócito), como controle observamos a presença das mesmas citocinas no sobrenadante de mastócito sem as células dendríticas (MC).

Figura 38. Capacidade estimuladora de células dendríticas imaturas co-cultivadas ou não com mastócitos.

Figura 39. Representação gráfica do resultado da diluição do CFSE.

Figura 40. Avaliação da expressão de FoxP3 nas células CD3+ CD4+ CD25+ quando estes linfócitos foram co-cultivados ou não com iDC previamente co-cultivas com mastócitos (iDC/MC) ou mastócitos sensibilizados (iDC/MCT).

Figura 41. Comparação da frequência de células CD3+CD4+CD25+FoxP3+ entre iDC cocultivadas com mastócito em monolayer (iDC-MC) contra co-cultivo em transwell (iDC/MC).

Figura 42. Avaliação da produção de IL-10 por linfócitos T co-cultivas com iDCs dos diferentes grupos experimentais.

Figura 43. Avaliação da produção de TGF- $\beta$ por linfócitos T co-cultivas com iDCs dos diferentes grupos experimentais.

Figura 44. Avaliação da capacidade supressora dos linfócitos CD3+CD4+ CD25+ oriundos do cocultivo com mastócito em sistema transwell

Figura 45. Avaliação da desgranulação de mastócitos após o co-cultivo em monolayer com células dendritícas.

Figura 46. Avaliação da desgranulação de mastócitos após o co-cultivo em monolayer com células dendritícas. . .89

Figura 47. Confirmação da dependência do contato celular para a geração de tDCs. . .90

Figura 48. Avaliação da expressão de PD-1 (CD279) na membrana de mastócitos diferenciados in vitro e da linhagem de mastocitoma humano HMC-1.1 
Figura 50. Análise da expressão de ID01 pelas células dendríticas co-cultivas com HMC-1.1.

Figura 51. Representação gráfica da análise da expressão de ID01 pelas células dendríticas cocultivas com HMC-1.1

Figura 52. Avaliação da produção de IDO nas iDCs após co-cultivo com HMC-1.1

Figura 53. Avaliação da produção de IDO nas iDCs após co-cultivo com HMC-1.1 quando bloqueado receptor histaminérgico 1 e 2 nas iDCs

Figura 54. Tratamento de HMC-1.1 com anti-PD-1 resulta na menor produção de TGF- $\beta$

Figura 55. Bloqueio do receptor de TGF- $\beta$ expresso pelas DCs, não altera a produção de IDO

Figura 56. Avaliação da produção de TNF- $\alpha$ em iDCs .98

Figura 57. Analise da expressão de STAT-3 nas iDCs co-cultivadas com HMC-1.1 99

Figura 58. Avaliação da proliferação de HCT-116 após co-cultivo com as linhagens de mastocitoma (HMC-1.1 ou HMC-1.2).... 100

Figura 59. Avaliação da expressão de CD117 na linhagem de CCR (HCT-116), após co-cultura em transwell com mastocitoma 


\section{Lista de Tabelas}

TABELA 1. FREQUÊNCIA DAS MOLÉCULAS DE SUPERFÍCIE NOS DIFERENTES GRUPOS DE CO-CULTIVO EM MONOLAYER.

TABELA 2. MFI DAS MOLÉCULAS DE SUPERFÍCIE NOS DIFERENTES GRUPOS DE CO-CULTIVO EM MONOLAYER ..........62

TABELA 3. FREQUÊNCIA DAS MOLÉCULAS DE SUPERFÍCIE NOS DIFERENTES GRUPOS DE CO-CULTIVO E TRANSWELL

TABELA 4. MFI DAS MOLÉCULAS DE SUPERFÍCIE NOS DIFERENTES GRUPOS DE CO-CULTIVO EM TRANSWELL 81 


\section{Lista de abreviaturas e siglas}

AACR

APCs

CCR

CCR7

CD

cDCs

CFSE

CLEC9A

CTLA-4

CTV

CNAs

DCs

DMSO

FGF2

FoxP3

GM-CSF

HCT-116

HLA-DR

HMC-1.1

HMC-1.2

iDC-MC

iDC/MC

iDCs

IDO

IFN

IL

INCA

IMDM

iTerg

LCs

MAPK

MC C

MC TC

MC TP

MCs

MCT

mDCs

MDSC

MFI

MHC- I

MHC- II

Mo-DCs

NFAT
Associação America para Pesquisa com Câncer

Células Apresentadoras de Antígenos

Câncer Colo-retal

$\mathrm{C}-\mathrm{C}$ receptor de quimiocina do tipo 7

"Cluster of differentiation"

Células dendríticas convencionais

Carboxifluoresceína succinimidyl éster

Lectina do tipo C pertencente a familia 9, membro A

Proteína 4 Associada a Linfócitos T Citotóxicos

Cell Trace Violeta

Células não aderêntes

Células dendríticas

Dimetilsulfóxido

Fator de crescimento de fibroblasto 2

Forhead Box P3 (Fator de transcrição de células T reguladoras)

Fator de Crescimento de Colônias de Granulócitos

Linhagem celular de câncer colo-retal humano

Antígeno Leucocitário Humano-DR

Linhagem celular de mastocitoma humano

Linhagem celular de mastocitoma humano

Células dendríticas co-cultivadas com mastócitos autólogos

Células dendríticas co-cultivadas com mastócitos em sistema transwell

Células dendríticas imaturas

Indoleamina 2,3 deoxigenase

Interferon

Interleucina

Instituto Câncer

"Iscove's Modified Dulbecco's Media"

Células T reguladoras induzidas

Células de Langerhans

Proteínas quinases ativadas por mitógenos

Mastócitos produtores de quimases

Mastócitos produtores de quimases e triptases

Mastócitos produtores de triptase

Mastócitos

Mastócito co-cultivado com células da linhagem tumoral HCT-116

Células dendríticas maduras

Célula mielóde supressora

Intensidade Mediana de Fluorescência

Complexo principal de Histocompatibilidade classe I

Complexo principal de Histocompatibilidade classe II

Células Dendríticas derivadas de monócitos

Fator Nuclear de ativação de linfócito T 
NFkB

NGF

NK

nTreg

OMS

PBMCs

PBS

pDCs

PDGF

PHA

SCF

SFB

STAT

tDC

TCR

TGF- $\beta$

Th

TNF- $\alpha$

Tr1

Tregs

VEGF
Fator Nuclear kB

Fator de crescimento de neural

"Natural Killer"

Células T reguladoras naturais

Organização Mundial da Saúde

Células Mononucleares do Sangue Periférico

Salina Tamponada com Fosfato

Células dendríticas plasmocitóides

Fator de crescimento derivado de plaquetas

Fitohemaglutinina A

Fator de crescimento de célula tronco

Soro Fetal Bovino

Transdutor de sinal e ativador de transcrição

Célula Dendtítica tolerogênica

Receptor de células $\mathrm{T}$

Fator de Crescimento e transformação beta

Linfócito $\mathrm{T}$ auxiliar

Fator de Necrose Tumoral alpha

Linfócitos T reguladores produtores de IL-10

Linfócitos $\mathrm{T}$ reguladores

Fator de crescimento endotelial 


\section{Sumário}

1 INTRODUÇÃO

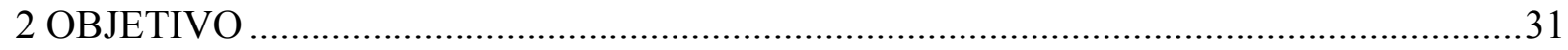

2.1 Metas específicas ..................................................................................................

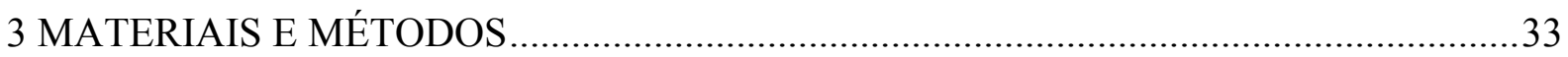

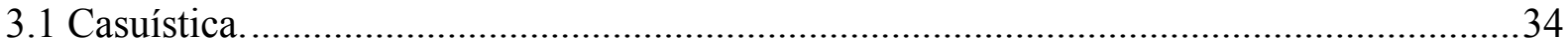

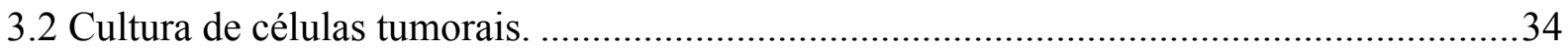

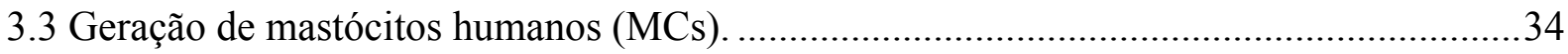

3.4 Imunofenotipagem de Mastócitos por citometria de fluxo.................................................35

3.5 Geração de células dendríticas humanas (DCs). …………………………………….......36

3.6 Co-cultura de células dendríticas e mastócitos em monolayer............................................37

3.7 Avaliação da viabilidade celular por MTT pós-sorting.......................................................37

3.8 Co-cultura de células dendríticas e mastócito com restrição de contato (Transwell). ........37

3.9 Imunofenótipo de células dendríticas por citometria de fluxo. .............................................38

3.10 Ensaio da proliferação de linfócitos $\mathrm{T}$ alogênicos co-cultivados com células dendríticas provenientes dos diferentes grupos experimentais. .............................................................38

3.11 Detecção de citocinas por ensaio de citometria por beads (CBA) ………………….........39

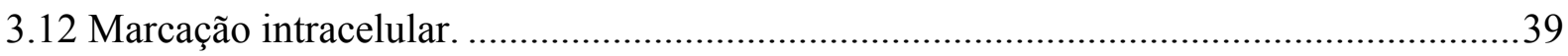

3.13 Ensaio de supressão da proliferação de linfócitos T alogênicos. .........................................41

3.14 Análise da liberação de grânulos por marcação de CD107a de membrana........................41

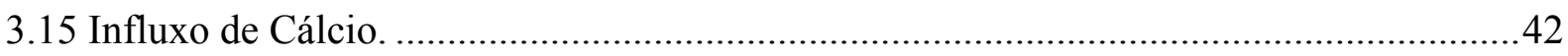

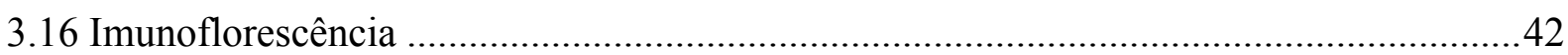

3.17 PCR quantitativo em tempo real (qPCR) para análise da expressão de indoleamina 2,3-

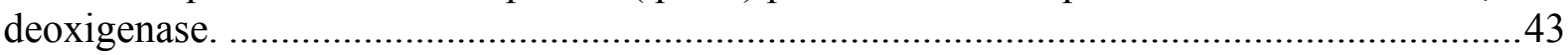

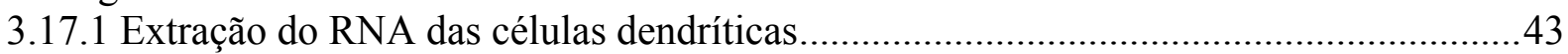

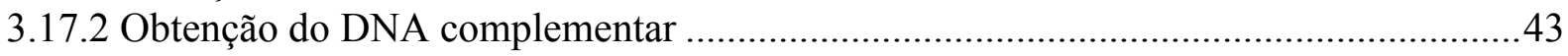

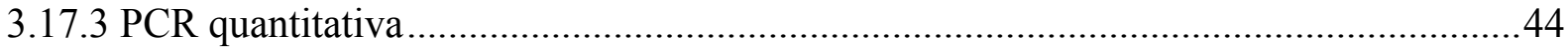

3.18 Marcação de Indoleamina 2,3-deoxigenase (IDO) por citometria de fluxo.......................44

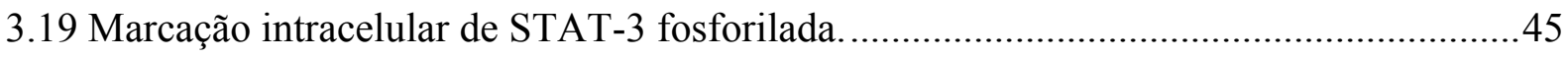

3.20 Avaliação de STAT-3 e pSTAT-3 por Western Blot. …………………………………....45

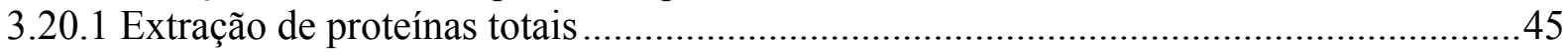

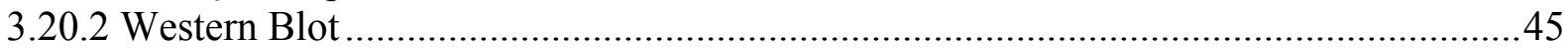

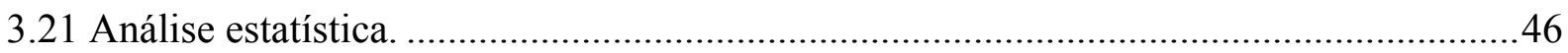

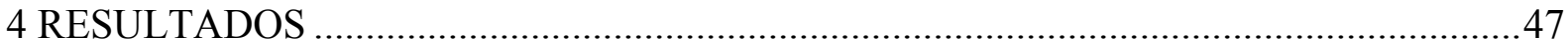

4.1 Padronizações e validação dos resultados ......................................................................48

4.1.1 Reação em cadeia da polimerase para detecção de contaminação por micoplasma.........48 
4.1.2 Avaliação da diferenciação de DC em meio de cultura IMDM-10 ................................48

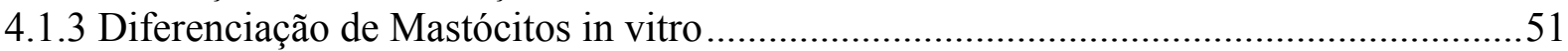

4.1.4 Avaliação morfologia e fenotípica das linhagens de mastocitoma HMC-1.1 e HMC-1.2

4.2 Sorting de HCT-116 e mastócitos diferenciados

4.3 Avaliação da presença de mastócitos após o sorting e da interação destas com células dendríticas autólogas.

4.4 Avaliação do fenótipo após co-cultura em monolayer.

4.5 Análise da produção de citocinas por células dendríticas co-cultivas com mastócitos......64

4.6 Avaliação da capacidade linfoestimuladora de células dendríticas co-cultivadas com mastócitos.

4.7 Análise da geração de células $\mathrm{CD}^{+} \mathrm{CD} 25^{+} \mathrm{FoxP} 3^{+}$(Tregs) por células dendríticas cocultivas com mastócitos.

4.8 Análise de citocinas presentes no sobrenadante e marcação intracelular de IL-10 e TGF- $\beta$ dos linfócitos $\mathrm{T}$ provenientes do co-cultivo com células dendríticas dos diferentes grupos experimentais.

4.9 Avaliação da supressão promovida por células $\mathrm{CD} 3^{+} \mathrm{CD} 4^{+} \mathrm{CD} 25^{+}$.

4.10 Co-cultura de células dendríticas e mastócito em um sistema com restrição de contato

(Transwell).

4.11 Análise da produção de citocinas por células dendríticas co-cultivas com $20 \%$ do sobrenadante de mastócito ou sobrenadante da co-cultura de mastócito com HCT-116.

4.12 Avaliação da capacidade linfoestimuladora de células dendríticas cultivadas com mastócitos em um sistema com restrição de contato (transwell).

4.13 Avaliação da produção de IL-10 e TGF- $\beta$ dos linfócitos T co-cultivados com células dendríticas provenientes da co-cultura com mastócitos em um sistema transwell. .87 4.15 Avaliação da desgranulação de mastócitos após o co-cultivo em monolayer com células dendríticas.

4.16 Avaliação da dependência do contato para a polarização de DCs tolerogênicas.

4.17 Avaliação do PD-1 expresso em mastócito como responsável para a indução de DCs tolerogênicas.

4.18 Quantificação relativa da expressão do gene IDO1 pelas células dendríticas co-cultivadas com linhagens de mastocitoma.

4.19 Avaliação da produção de TGF- $\beta$ de mastócitos após co-cultura com células dendríticas.

4.20 Tratamento prévio das células HMC-1.1 com anti-PD-1 impede a geração de DCs tolerogênicas.

4.21 Células tumorais. 


\section{INTRODUÇÃO}

O câncer é, atualmente, um problema de saúde pública tanto nos países desenvolvidos como nos países em desenvolvimento. Segundo dados da Organização Mundial da Saúde, estima-se que, até o ano de 2030, haja 27 milhões de novos casos da doença (OMS, 2012). No Brasil, as estimativas para o ano de 2014 apontam a ocorrência de, aproximadamente, 576.580 novos casos da doença, sendo que, desses, 32.600 entre homens e mulheres serão de câncer colorretal (CCR) (Inca, 2014). Tais dados indicam que o CCR ocupa o segundo lugar entre os tipos mais frequentes de câncer e a quarta causa mais comum de morte por essa doença (International Agency for Research on Cancer, 2014). O alto consumo de frutas, vegetais frescos, cereais e peixes, bem como a prática de atividades físicas estão associados a um baixo risco de desenvolvimento do CCR. Por outro lado, o consumo excessivo de carne vermelha, embutidos, bebidas alcoólicas, tabagismo e a obesidade ou o sobrepeso favorecem o desenvolvimento desse tipo de câncer (Acs, 2008; Inca, 2014; Wimberly, 2014). No entanto, além dos fatores externos, destaca-se a inflamação crônica no órgão-alvo, como agente adjuvante da carcinogênese (Coussens, Werb, 2001; Lynch et al., 1993; Rakoffnahoum, 2006; Taniguchi, Karin, 2014). Pacientes portadores de Doença de Crohn apresentam uma incidência 20 vezes maior de CCR e com vinte anos de antecedência média em relação àqueles livres dessa condição (Brackmann et al., 2009; Harpaz, Talbot, 1996; Triantafillidis, Nasioulas, Kosmidis, 2009). Nessa direção de estudos, sabe-se que condições de inflamação estão associadas à patogênese de vários tipos de câncer. Por exemplo, observase que camundongos que apresentam resposta inflamatória aguda intensa (AIRmax) são mais suscetíveis ao desenvolvimento de câncer de cólon quimicamente induzido, do que os animais com reação inflamatória discreta (AIRmin) (Di Pace, 2006).

Do ponto de vista celular, o sítio tumoral é um microambiente composto não só de células transformadas, ou seja, células independentes de mecanismos de ancoragem, de fatores de crescimento e de inibição, mas também por células não neoplásicas, como as células mesenquimais, componentes vasculares e células do sistema imune (Hanahan, Weinberg, 2011; Kerkar, Restifo, 2012; Rahir, Moser, 2012). As células e seus produtos compõem um microambiente dinâmico e complexo, no qual o sistema imune parece ter papel essencial e cuja compreensão, portanto, é essencial para o aprimoramento de abordagens terapêuticas eficazes (Hanahan, Weinberg, 2011; Sun, Nelson, 2012). 
Tumores sólidos humanos e murinos, geralmente, são infiltrados por componentes celulares do sistema imune, tais como linfócitos $\mathrm{T}$ e $\mathrm{B}$, células natural killer (NK), células dendríticas (DCs), macrófagos, eosinófilos, mastócitos, células mieloides imaturas e células mieloides supressoras (MDSC) (Benencia, Sprague, McGinty, Pate, Fricke, 2007, Kerkar, Restifo, 2012; Muccioli, 2012; Prizment, Anderson, Visvanathan, Folsom, 2011; Rahir Moser, 2012; Wikberg, Oldenborg, Palmqvist, 2013). A princípio, espera-se que as células do sistema imune desempenhem o papel previsto na hipótese da vigilância imunológica proposta por Paul Ehrlich no início do século XX e revista por Burnet (apud Klein, 2005), segundo a qual o sistema imune reconheceria e eliminaria células neoplásicas antes mesmo da formação de uma massa. Evidências que esta vigilância existe se encontram na ocorrência de regressão espontânea de tumores (Baker, 1976; Papac, 1996, 1998), na maior incidência de câncer em indivíduos imunodeficientes (Engels et al., 2008) e no aumento da sobrevida de pacientes tratados com anticorpos contra as moléculas CTLA-4 e PD-1 (Quezada, Peggs, 2013; Taube et al., 2014; Topalian, Drake, Pardoll, 2012; Zitvogel, Kroemer, 2012), ambas sabidamente capazes de inibir a resposta imune (Probst, McCoy, Okazaki, Honjo, Van den Broek, 2005; Youngnak et al., 2003).

Entretanto, aparentemente em contradição com o papel esperado para as células do sistema imune, estas, quando situadas no microambiente tumoral, geralmente, apresentam-se em um estado suprimido e funcionalmente comprometidas (Gabrilovich, 2006; Je-in Youn, 2008; Rahir, Moser, 2012; Tran, 2012). O que pode ser explicado, em parte, pelo fato de que a carcinogênese pode ser associada à inflamação crônica, em que células do sistema imune persistem no local de inflamação provocando lesões teciduais, angiogênese desregulada e remodelação tecidual anormal (Brackmann et al., 2009; Heijmans, Büller, Muncan, Van den Brink, 2012; Lisa et al., 2001; Shea-Donohue, Stiltz, Zhao, Notari, 2010).

Dentre as células do sistema imune envolvidas com a remodelação tecidual, estão os mastócitos, fato evidenciado pelo trabalho de Coussens e Werb (2002), que demonstrou a produção de mMCP-6 (triptase) como necessária para ativação de fibroblastos da derme. $\mathrm{O}$ mesmo trabalho mostrou, ainda, que a presença de mastócitos está intimamente relacionada com a presença de $\alpha-1$ colágeno no tecido. Ademais, mastócitos são produtores de diferentes fatores de crescimento, incluindo fator de crescimento de neural (NGF), fator de crescimento derivado de plaquetas (PDGF), fator de crescimento endotelial (VEGF) e fator de crescimento de fibroblastos-2 (FGF2) (J. Liu et al., 2011), todos eles associados à remodelação tecidual. 
Os mastócitos foram descobertos no mesentério de sapos em 1863 por Dr. Von Recklingahusen, no entanto, somente em 1878 receberam o nome de "Mastzellen", do Alemão, "Mast”, que significa "engorda" e "zellen”, célula, por Paul Ehrlich (Ehrlich, 1878) (apud Beaven, 2009; Vyas, Krishnaswamy, 2005).

Os mastócitos são caracterizados como células derivadas de precursores hematopoiéticos da medula óssea, que migram ainda imaturos do sangue para tecidos periféricos, em que completam sua maturação (Maltby, Khazaie, McNagny, 2009). De maneira geral, em humanos, estas células são classificadas com base nos conteúdos intracelulares de serino-proteases, sendo, assim, denominados como mastócitos produtores de triptase (MC TP), mastócito produtores de quimase (MC C) ou capazes de produzir ambas (MC TC). Sendo que MC TP são, comumente, encontrados em mucosa e os MC TC em tecidos conjuntivos (Moon et al., 2010). No entanto, diferente dos roedores, em humanos, não existe uma delimitação anatômica exata dos subtipos de mastócitos, uma vez que o fenótipo dessa célula, bem como sua maturação são diretamente dependentes dos fatores do microambiente no qual estão inseridas, então, tanto seu fenótipo quanto funções não são fixas, e podem variar em resposta às citocinas e aos fatores de crescimento (Jensen et al., 2014; Krow-Lucal, Kim, Burt, McCune, 2014).

De modo geral, os mastócitos residem próximos aos vasos sanguíneos, aos nervos e às superfícies de mucosas, e são consideradas células de resposta rápida frente a agressões teciduais (Grimbaldeston, Finlay-Jones, Hart, 2006; J. Liu et al., 2011). Todavia, recentemente, foram descritos como sendo capazes de induzir a diferenciação de macrófagos para o padrão M2, de maneira dependente de IL-10, gerando a tolerância imune frente a bactérias em um modelo murino de infecção urinária por E. Coli (Chan, St John, Abraham, 2013), sugerindo um possível papel supressor de mastócitos.

Este viés imunossupressor de mastócitos torna-se interessante ao considerarmos os trabalhos que apontam estas células como um dos primeiros e mais persistentes tipos celulares encontrados no infiltrado tumoral, estando presentes na periferia de vários tumores em desenvolvimento, tais como pólipos adenomatosos, displasias epiteliais, melanomas e alguns carcinomas, como mamário e CCR (Blatner et al., 2010; Gulubova et al., 2012; Heijmans et al., 2012; Maltby et al., 2009; Shea-Donohue et al., 2010; Theoharides, Conti, 2004). Embora os trabalhos quanto à ação dos mastócitos no nicho tumoral sejam relativamente recentes, o primeiro relato do infiltrado de mastócitos em tumores sólidos ocorreu em 1891 por 
Westphal, em que foi observado aumento de células metacoradas em volta de diversos tipos de tumores sólidos (apud Maltby et al., 2009). No entanto, sua específica função nesse contexto ainda não foi determinada.

Em 1983, Poole e Zetter observaram que a migração de mastócitos em direção ao sítio tumoral ocorria de maneira específica. Nesse estudo, foi demonstrado que essas células quando em suspensão migram em direção aos sobrenadantes de diferentes linhagens de células tumorais humanas e murinas, mas o mesmo não acontece quando o sobrenadante era proveniente da cultura de células não tumorais (Poole, Zetter, 1983). Após alguns anos, foi sugerido que esta migração preferencial ocorria, pois células tumorais são capazes de produzir fatores de células tronco (SCF), sendo este o principal responsável pelo recrutamento de mastócitos para a região tumoral. Nesse mesmo estudo, desenvolvido por Huang et al., foi relatada a transferência do receptor c-kit (CD117) presente nos mastócitos para as células tumorais, permitindo que as células tumorais se utilizem da via c-kit/SCF, de maneira parácrina (Huang et al., 2008).

Em mastócitos, a via c-kit/SCF é capaz de provocar sua ativação, levando à liberação de três classes de mediadores: aqueles pré-formados (e armazenados em grânulos), mediadores lipídicos, sintetizados de novo, e mediadores proteicos (citocinas e quimiocinas). No microambiente tumoral, todos estes mediadores podem participar do processo de formação e manutenção de um microambiente favorável à doença e à formação de metástases (Aoki, Pawankar, Niimi, Kawana, 2003; Gilfillan, Tkaczyk, 2006; Huang et al., 2008; Murdoch, Muthana, Coffelt, Lewis, 2008; Rodriguez Faba et al., 2012; Theoharides, Kempuraj, Tagen, Conti, Kalogeromitros, 2007). Além do mais, embora sem terem sua função exatamente definida, receptores histaminérgicos estão presentes em diversas células tumorais, abrindo a possibilidade de que os mastócitos influenciem, diretamente, também, o crescimento das células neoplásicas (Dyduch, Kaczmarczyk, Okoń, 2012).

Paralelamente, quando mastócitos são ativados via c-kit/SCF, acionam os fatores nucleares NF-kB e NFAT, o que resulta na secreção de citocinas pró-inflamatórias como IL1ß, IL-6, TNF- $\alpha$ e IL-8 (Aoki et al., 2003; Soucek et al., 2007). Tais citocinas podem contribuir para a progressão da doença, pois garantem um ambiente inflamatório propício para o desenvolvimento tumoral. Isto pode ser observado, por exemplo, no trabalho de Lesina et al. (Lesina et al., 2011), em que a presença da citocina IL-6 no sítio tumoral resultou na ativação de STAT-3, o que culminou na progressão de neoplasias pancreáticas intraepiteliais. 
Por outro lado, ilustrando ainda mais a dependência das diversas interações entre células e moléculas no microambiente no qual ocorre uma resposta, Ribatti et al. (Crivellato, Nico, Ribatti, 2008) observaram que triptase e sulfato de condrocitina sintetizados pelo infiltrado de mastócitos foram capazes de promover ações antitumorais em camundongos, principalmente pela contenção da proliferação de células tumorais. Em humanos, Gooch et al. (Gooch, Lee, Yee, 1998) demonstraram que a citocina IL-4, produzida por mastócitos presentes no infiltrado tumoral, foi capaz de induzir apoptose das células malignas. Nessa mesma linha, foi demonstrado que a produção de IL-5 por mastócitos era associada com a presença e permanência de eosinófilos no microambiente tumoral (Prizment et al., 2011), sendo que, ao menos em modelo murino de fibrossarcoma, os eosinófilos demonstraram importante ação efetora contra as células tumorais (Simson et al., 2007). Além disso, foi demonstrado que o TNF- $\alpha$ produzido por mastócitos parece ser capaz de aumentar a proliferação de linfócitos T (Nakae et al., 2005), bem como induzir a migração de DCs para os locais com lesões e ativação dessas células (Jawdat, Rowden, Marshall, 2012; Suto et al., 2006). Nestas linhas, Guermonprez et al. demonstraram que, na presença de ácido úrico, os mastócitos secretam FLT3L, sendo este essencial tanto para a mobilização de DCs quanto para a ativação de linfócitos T, durante a infecção por Plasmodium (Guermonprez et al., 2013); demonstrando, assim, a possível relação entre mastócitos e DCs in vivo.

O primeiro relato da existência das DCs foi descrito por Paul Langerhans em 1868, sendo células presentes na camada basal da epiderme, compostas por longos e ramificados prolongamentos semelhante aos dendrítos neuronais. Assim, ao considerar a distribuição anatômica e morfologia das células, Paul Langerhans considerou-as como um subtipo de neurônio (apud Stoitzner, 2010). Apenas em 1973, com os trabalhos de Steinman, estas células foram consideradas um novo tipo celular pertencente ao sistema imune (Cohn, Steinman, 1973; Mellman, Fitch, 2012, Nussenzweig, 2011; 2007; Rowley, Steinman MR, 2003).

Atualmente, estas células são reconhecidas como as células apresentadoras de antígeno (APCs) mais eficazes (Steinman MR, 2003), isto, pois, nos tecidos, estas costumam estar em um estado denominado "imaturo". Nestas condições, as DCs exercem o papel de "monitoramento" do microambiente no qual estão inseridas, uma vez que possuem uma alta capacidade endocítica e fagocítica, resultando na grande eficiência da captura de antígenos. Mas, quando "imaturas", estas células expressam baixas quantidades de moléculas co- 
estimuladoras e citocinas inflamatórias, portanto, não são capazes de ativar os linfócitos $\mathrm{T}$ para um viés imunogênico, mas sim de tolerância ao que se é "apresentado". No entanto, após desequilíbrio homeostático, ou seja, um sinal de "perigo", tanto endógeno quanto exógeno, as DCs sofrerem um processo denominado "maturação". Este processo de ativação das DCs resulta em uma série de modificações fenotípicas e funcionais (Banchereau et al., 2000; Guermonprez, Valladeau, Zitvogel, Théry, Amigorena, 2002; Savina, 2007).

De modo geral, após a maturação, as DCs sofrem alterações quanto à captação, ao processamento e à apresentação de antígenos presentes no microambiente; ou seja, ocorre a diminuição da endocitose, aumento da expressão da molécula principal de histocompatibilidade (MHC) de classe II na membrana celular; pois o transporte, a internalização e a degradação (processo de reciclagem) desta molécula é diminuído durante a maturação. Com isto, as DCs passam a "expor" os antígenos provenientes dos agentes patogênicos ou danosos presentes no local de perigo de forma "estável". Ademais, durante o processo de "maturação" das DCs, ocorre o aumento da expressão de moléculas coestimuladoras, como CD86, CD80 e CD40, permitindo, assim, que as DCs se tornem capazes de promover o "segundo sinal" de ativação de linfócitos T, aumentado, desta forma, a capacidade de apresentação de antígenos pelas DCs. Portanto, estas células são consideradas as únicas células capazes de ativar os linfócitos $\mathrm{T}$ nä̈ve e iniciar a resposta imune adaptativa (Banchereau, Steinman, 1998; Bugeon, Dallman, 2000; Caux et al., 1994; Celia et al., 1996; Guermonprez et al., 2002).

No entanto, para que ocorra a promoção da resposta imune, as DCs precisam interagir com os linfócitos T. logo, durante o processo de maturação, as citocinas inflamatórias, o aumento da expressão da molécula CCR7 (DCs), e os mediadores inflamatórios presentes no microambiente geram estímulo para a migração das DCs do tecido inflamado para os órgãos linfoides secundários, especificamente, para a área de linfócitos $\mathrm{T}$, em que, nestas condições de ativação ("maduras", mDC), são capazes de interagir com os linfócitos T, engatilhando, assim, uma resposta imune imunogênica. Além disso, as mDC podem recrutar outras DCs e linfócitos $\mathrm{T}$ por meio da produção de citocinas e quimiocinas (Clatworthy et al., 2014; Förster, Davalos-Misslitz, Rot, 2008; Randolph, Angeli, Swartz, 2005).

Do ponto de vista funcional e ontogênico, as DCs constituem uma população heterogênea tanto em camundongos quanto em humanos, principalmente pela gama de marcadores moleculares de superfície e os diferentes estados de maturação e ativação (Collin, 
McGovern, Haniffa, 2013). Embora seja controverso, o sistema de divisão é, basicamente, constituído por quatro subtipos celulares: DCs mieloides convencionais ou clássicas (cDC) $\left(\mathrm{BDCA}^{+}{ }^{\text {ou }} \mathrm{BDCA}^{+}{ }^{+}\right.$) (Satpathy et al., 2012), DCs plasmocitoides $\left(\mathrm{CD} 11 \mathrm{c}^{+} \mathrm{CD} 123^{+} \mathrm{CD} 303^{+}\right.$) (pDC) (Colonna, Trinchieri, Liu, 2004; Reizis, Colonna, 2011), células de Langerhans $\left(\mathrm{CD}_{1} \mathrm{a}^{+}\right.$Langerina $\left.{ }^{+}\right)$(LCs) (Toebak et al., 2009) e DCs derivadas de monócitos $\left(\mathrm{CD} 14{ }^{\text {low }} \mathrm{CD} 11 \mathrm{c}^{+}\right)$(mo-DCs) (Amigorena, Segura, 2013; Lanzavecchia,Sallusto, 1994; Naik Shortman, 2007).

As cDCs são altamente especializadas na captura e no processamento antigênico, possuem meia-vida de, aproximadamente, 5 dias e são continuamente repostas pela medula óssea (Liu et al., 2007). Estas células são encontradas tanto na circulação quanto em tecidos e são, classicamente, divididas em dois compartimentos: cDCs XCR $1^{+} \mathrm{BDCA} 3^{+} \mathrm{CLEC} 9 \mathrm{~A}^{+}$, homólogas às células (DCs) $\mathrm{CD} \alpha^{+}$murinas, portanto, células assaz eficientes para apresentação cruzada (Amigorena, Guermonprez, 2005; Amigorena, Durand, Segura, 2013) e

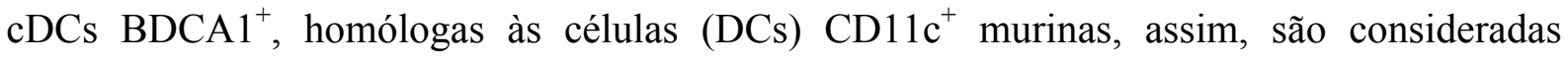
células com baixa capacidade de realizar apresentação cruzada, mas eficientes quanto à apresentação de antígeno via MHC classe II (Collin et al., 2013; Dudziak et al., 2007).

Em contrates com cDCs, as pDCs não possuem dendritos, são células esféricas semelhantes aos plasmócitos e fundamentais para a resposta frente a estímulos virais (agonistas de TLR-7 e TLR-9), sendo que, após exposição deste agonistas, as pDCs são capazes de produzir grandes quantidades de interferon do tipo I, por exemplo, IFN- $\alpha$. Curiosamente, no entanto, quando comparadas com cDCs, as pDCs possuem menor capacidade de ativar os linfócitos T (Reizis et al., 2011).

Embora as DCs sejam encontradas na circulação ou nos tecidos, a frequência dos subtipos descritos é baixa, o que dificulta o estudo destas células (Guermonprez et al., 2002). Felizmente, seus percussores, como CD34+ (Caux et al., 1997; Caux, Dezutter-Dambuyant, Schmitt, Banchereau, 1992) e monócitos CD14 (Lanzavecchia, Sallusto, 1994), são, facilmente, obtidos da corrente sanguínea, o que torna possível a diferenciação in vitro das DCs. Assim, DCs mieloides podem ser geradas pela adição do fator estimulante de colônias de granulócitos macrófagos (GM-CSF) e TNF- $\alpha$, no caso de células $\mathrm{CD}^{+} 4^{+}$ou pela adição de GM-CSF e IL-4 no caso de monócitos. As DCs geradas por estes protocolos possuem características de DCs imaturas, estas podem ser induzidas à maturação com a adição de citocinas inflamatórias, como TNF- $\alpha$, ligantes de molécula de co-estímulo, como, por 
exemplo, CD40-L ou ligantes dos receptores de reconhecimento padrão do sistema inato, como, por exemplo, o LPS, sabidamente um agonista de TLR-4. O processo de maturação por estes estímulos pode ser evidenciada, dentre outros fatores, pelo aumento da expressão de moléculas co-estimuladoras (Caux et. al, 2012; Verhasselt et al., 1997).

No entanto, vale ressaltar, que, embora seja crucial, o aumento da expressão de moléculas co-estimuladoras nas DCs, para a ativação de linfócitos $\mathrm{T}$ nä̈ve, ainda se faz necessário mais um "sinal". Sinal este provido in situ pelas APCs que interagem com os linfócitos T, como, por exemplo, as citocinas (Guermonprez et al., 2002). De maneira geral, postula-se que a produção de IL-12 pelas DCs favorece o desenvolvimento de linfócitos Th1, enquanto a presença de IL-4/IL-13 favorece uma reposta, predominantemente, mediada por linfócitos Th2. TGF- $\beta$, em adição de IL-6, parece favorecer o desenvolvimento de linfócitos Th17, caracterizados pela produção de IL-17 importantes para a manutenção da inflamação (Mosmann et al., 1986; Nakayamada et al., 2012; Zhou et al., 2009). Por outro lado, a presença de TGF- $\beta$ e IL-10 parece favorecer a indução de linfócitos T reguladores (Tregs), caracterizados, dentre outros marcadores, pela expressão do fator de transcrição FoxP3 (do Inglês, forkhead box P3) (Abbas, Bluestone 2003; Jonuleit, Schmitt, 2003; Samanta et al., 2008; Tran, 2011).

As Tregs possuem papel fundamental para a homeostase do organismo, estas células são subdivididas em dois subtipos: Tregs naturais (nTreg) ou Tregs induzidas (iTreg). As nTreg são diferenciadas no timo e possuem, principalmente, a função de suprimir respostas imune autorreativas, para tal não necessitam “instrução" periférica de APCs, como DCs. Por outro lado, as iTregs são, geralmente, diferenciadas na periferia, um dos mecanismos de indução das iTres pode ser consequência da interação de DCs, não ativadas, com linfócitos T (Abbas, Bluestone, 2003; Jonuleit, Schmitt, 2003). De modo simplificado, existem dois tipos de iTregs: Th3 e Tr1; distinguidas pelas citocinas por elas produzidas (Jonuleit, Schmitt, 2003). Th3 são células que secretam, preferencialmente, TGF- $\beta$, assim, parecem possuir um papel importante para a tolerância oral (Weiner, 2001). O outro subtipo de linfócitos iTregs são as células T reguladoras do tipo $1(\mathrm{Tr} 1)$, estas células produzem, preferencialmente, IL10, na ausência de IL-4 (Bacchetta et al., 2002; Roncarolo, Bacchetta, Bordignon, Narula, Levings, 2001). De modo geral, os subtipos de iTregs parecem ser importante para a regulação do sistema imune, sendo ambos essenciais para a tolerância periférica, regulação de tecidos inflamados e reparo tecidual após inflamação (Jonuleit, Schmitt, 2003). 
O estudo das DCs, portanto, mostra que estas células possuem um papel fundamental no desencadeamento, na manutenção e no término da resposta imune frente a um sinal de perigo. Assim, tais fenômenos não poderiam ser diferentes nos casos de tumores, evidenciados, principalmente, pela indução da resposta antitumoral em modelos de vacinação com DCs carregadas com antígenos associados aos tumores (Banchereau et al., 2001; Banchereau, Palucka, 2013; Banchereau, Steinman, 2007).

Intrigantemente, as DCs estão presentes em diversos tipos de tumores e, embora a presença e migração de DCs para o sítio tumoral pudessem ser vantajosas para a eventual eliminação do tumor pela resposta imune (Banchereau, Palucka, 2013; Smith et al., 2012; Banchereau, Steinman, 2007), foi demonstrado em camundongos e humanos que diversos fatores presentes no microambiente tumoral, entre os quais o VEGF, a IL-4, a IL-6 e a IL-10, as mantêm em um estado imaturo (Baleeiro et al., 2008; Benencia et al., 2012; Fricke, Gabrilovich, 2006; Harizi et al., 2002; Kerkar, Restifo, 2012; Vicari et al., 2002; Yang et al., 2010), assim, polarizando a resposta imune, principalmente à tolerância dos antígenos e não ativação imunogênica de linfócitos T. Devido, dentre outros fatores, pela baixa expressão de moléculas de co-estímulo, produção de citocinas anti-inflamatórias e produção da enzima indoleamina 2,3-dioxigenase (IDO) (Holmgaard, Zamarin, Munn, Wolchok, Allison, 2013; Zamanakou, Germenis, Karanikas, 2007). A presença de iDCs no sítio tumoral acabaria, portanto, contribuindo para o perfil imunossupressor do microambiente tumoral (Fricke, Gabrilovich, 2006).

Portanto, considerando o microambiente tumoral como fator fundamental na indução de imunidade contra tumores, a presença frequente de mastócitos nesse, principalmente em tumores associados à inflamação, e os trabalhos que relatam a capacidade imunossupressora de mastócitos. O presente trabalho se propõe a investigar, em seres humanos, os efeitos dos mastócitos sobre o fenótipo e a função de DCs, células essenciais para o início da resposta imune. Procurando, assim, contribuir para a compreensão da interação de mastócitos e DCs no microambiente tumoral como um possível mecanismo de indução das DCs para um viés tolerogênico. 
2 OBJETIVO 


\section{OBJETIVO}

Com base na dualidade da ação encontrada na literatura e nas diferenças de mastócitos inerentes a espécies, humanos e camundongos, o presente trabalho foi formulado com o intuito de avaliar os efeitos de mastócitos humanos sobre o fenótipo e a função de DCs autólogas derivadas de monócitos.

\subsection{Metas específicas}

$\checkmark$ Gerar e caracterizar mastócitos humanos a partir de precursores mieloides (CD34) presentes no sangue periférico;

$\checkmark$ Sensibilizar os mastócitos gerados com células de CCR da linhagem HCT-116;

$\checkmark$ Avaliar o imunofenótipo de DCs co-cultivadas diretamente com mastócitos (sensibilizados com células tumorais ou não) em um sistema de cultura monolayer ou em transwell;

$\checkmark$ Avaliar a produção de citocinas e da capacidade de aloestimulação de linfócitos T estimulados com DCs expostas ou não aos mastócitos. 
3 MATERIAIS E MÉTODOS 


\section{MATERIAIS E MÉTODOS}

\subsection{Casuística.}

As amostras de sangue necessárias para a diferenciação de mastócitos células dendríticas e linfócitos neste estudo foram obtidas do Banco de Sangue do Hospital Alemão Oswaldo Cruz, a partir de câmaras de leucorredução de plaquetaférese, de doadores saudáveis, após assinatura do Termo de Consentimento Livre e Esclarecido, sendo que a casuística foi composta por 30 doadores saudáveis.

3.2 Cultura de células tumorais.

Células de câncer colorretal humano, HCT-116, cedidas pelo prof. Dr. Ramon Kaneno, do Instituto de Biociências de Botucatu, da Universidade Estadual Paulista Júlio de Mesquita Filho (UNESP),SP; oriundas do Laboratório de Imunologia de Tumores Departamento de Patologia da Universidade de Pittsburgh, PA. Foram mantidas em cultura em meio de cultura constituído por Iscove Modified Dulbeco's Medium (IMDM) suplementado com $10 \%$ de soro fetal bovino (IMDM-10) a $37^{\circ} \mathrm{C}$, sob saturação de $5 \%$ de $\mathrm{CO}_{2}$ até completar a monocamada de células aderentes.

\subsection{Geração de mastócitos humanos (MCs).}

Para obtenção de MCs humanos, foi realizado o protocolo propostos por Saito et al. (Saito, Kato, Matsumoto, Okayama, 2006). Brevemente, MCs foram gerados a partir de células $\mathrm{CD} 34^{+}$de sangue periférico de doadores saudáveis, selecionadas a partir de câmaras de leucorredução de plaquetaférese, em que foram utilizados, aproximadamente, $10 \mathrm{~mL}$ de produto de câmara de leucorredução de doadores de plaquetas, estes foram diluídos 1:2 em salina tamponada com fosfato (PBS) e colocado sobre $12 \mathrm{~mL}$ de Ficoll-Paque para obtenção de células mononucleares. O material foi centrifugado a $900 \mathrm{~g}$ por 30 minutos e sem breque. Posteriormente, a camada de células mononucleares formada foi retirada, colocada em outro tubo cônico e acrescido RPMI- 1640, para nova centrifugação a 600 g por 10 minutos. As células foram lavadas por mais 2 vezes a 400 e $200 \mathrm{~g}$. As células mononucleares foram, então, submetidas à seleção positiva por beads magnéticas anti-CD34 (Progenitor cell isolation kit ${ }^{\odot}$ Miltenyi Biotec), após seleção, as células $\mathrm{CD}^{+} 4^{+}$foram mantidas em $0,3 \mu \mathrm{L}$ de meio metilcelulose, METHOCULT/SF${ }^{\mathrm{BIT}}$ (StemCell Inc.) acrescido de $2,1 \mathrm{~mL}$ de IMDM suplementado com SCF (100 $\mu \mathrm{g} / \mathrm{mL})$, IL-6 $(2 \mu \mathrm{g} / \mathrm{mL})$, IL-3 $(2,5 \mu \mathrm{g} / \mathrm{mL})$, penicilina-estreptomicina (10 
$\mathrm{U} / \mathrm{mL}$ e $10 \mathrm{mg} / \mathrm{mL}$, respectivamente) e 2-mercaptoetanol $\left(5,5 \times 10^{-2} \mathrm{M}\right)$. As células foram mantidas nestas condições durante duas semanas. Na segunda semana, foram acrescentados mais $0,3 \mu \mathrm{L} /$ poço de um novo meio de cultura, este era constituído por meio metil-celulose, METHOCULT/SF ${ }^{\mathrm{BIT}}$, IMDM suplementado com SCF $(100 \mu \mathrm{g} / \mathrm{mL})$, IL-6 $(2 \mu \mathrm{g} / \mathrm{mL})$ penicilina-estreptomicina $(10 \mathrm{U} / \mathrm{mL}$ e $10 \mathrm{mg} / \mathrm{mL}$, respectivamente) e 2-mercaptoetanol (5,5 x $\left.10^{-2} \mathrm{M}\right)$. Na quarta semana de cultura, os poços foram suplementados com $1 \mathrm{~mL}$ de IMDM suplementado com SCF (100 $\mu \mathrm{g} / \mathrm{mL})$, IL-6 $(2 \mu \mathrm{g} / \mathrm{mL})$, penicilina-estreptomicina (10 U/mL e $10 \mathrm{mg} / \mathrm{mL}$, respectivamente), 2-mercaptoetanol $\left(5,5 \times 10^{-2} \mathrm{M}\right)$ e $100 \mu \mathrm{L}$ de solução comercial, contendo insulina, transferrina e selênio (cat \#51300-044, Gibco BRL). Após 42 dias, foi possível observar o aparecimento de colônias de mastócitos, as células foram ressuspensas em PBS e centrifugadas a 600 g por 10 minutos, à temperatura ambiente. O sobrenadante foi descartado e o pellet ressuspendido em $20 \mathrm{~mL}$ de meio IMDM suplementado com SCF (100 $\mu \mathrm{g} / \mathrm{mL})$, IL-6 (2 $\mu \mathrm{g} / \mathrm{mL})$, penicilina-estreptomicina (10 U/mL e $10 \mathrm{mg} / \mathrm{mL}$, respectivamente), 2-mercaptoetanol $\left(5,5 \times 10^{-2} \mathrm{M}\right) 200 \mu \mathrm{L}$ de PBS-BSA $(1 \%)$ e $200 \mu \mathrm{L}$ solução comercial, contendo insulina, transferrina e selênio (cat \# 51300-044, Gibco BRL), assim, foram mantidas em placa de 12 alvéolos por mais uma semana. Interessantemente, por se tratar de células não aderentes à metodologia de plaquear as células em diferentes placas durante a diferenciação, resultou em um maior enriquecimento da cultura. Após 50 dias de cultura, foi realizada, por citometria de fluxo, a caracterização fenotípica das células, sendo que foi determinando a expressão das seguintes moléculas de membrana: FcદRI $\alpha$, CD33, CD13 e CD117. Confirmada a diferenciação, os MCs foram mantidos em cultura em placas de 6 alvéolos com meio IMDM-10 suplementado com SCF $(10 \mu \mathrm{g} / \mathrm{mL})$, em estufa a $37^{\circ} \mathrm{C}$ e saturação de $5 \%$ de $\mathrm{CO}_{2}$.

\subsection{Imunofenotipagem de Mastócitos por citometria de fluxo.}

Após diferenciação de MCs, estes foram corados com azul de toluidina para confirmação da presença de grânulos intracelulares. Confirmada a presença dos grânulos, $1 \times 10^{5} \mathrm{MCs}$ foram colocados em tubos cônicos de $1,5 \mathrm{~mL}$, e centrifugados por 30 segundos a $12.000 \mathrm{~g}$, a $4^{\circ} \mathrm{C}$. Então, foram adicionados aos tubos os anticorpos específicos nas concentrações apropriadas para os marcadores de interesse: CD13 (marcador do comprometimento mieloide), CD33 (marcador de célula mieloide), CD117/c-Kit (Receptor de SCF), FceRIa (Receptor de alta afinidade de IgE) e PD-1 (Proteína de programação para morte-1). Posteriormente, os tubos foram incubados por 20 minutos a $4^{\circ} \mathrm{C}$, com restrição de luz. Transcorrido o tempo, os tubos foram centrifugados e as células foram lavadas três vezes 
com $300 \mu \mathrm{L} /$ tubo de tampão para citometria (PBS - p.H=7,2, contendo $0,5 \%$ de soro albumina bovina e $0,02 \%$ de azida sódica).

Após estas lavagens, as células foram ressuspendidas em $200 \mu \mathrm{L}$ de tampão para citometria e analisadas no citômetro (FACScantoII ${ }^{\circledR} \mathrm{BD}$ ), utilizando-se o software FlowJo versão 8.7.2 (Three Star) para análise.

3.5 Geração de células dendríticas humanas (DCs).

Foram utilizados, aproximadamente, $10 \mathrm{~mL}$ de produto de câmara de leucorredução de doadores de plaquetas. Este foi diluído 1:2 em PBS e colocado sobre $12 \mathrm{~mL}$ de Ficoll-Paque para obtenção de células mononucleares. O material foi centrifugado a $900 \mathrm{~g}$ por 30 minutos sem breque. Posteriormente, a camada de células mononucleares formada foi retirada, colocada em outro tubo com RPMI- 1640, para nova centrifugação a 600g por 10 minutos. As células foram lavadas por mais 2 vezes a 400 e 200g. O pellet final foi coletado, e as células foram quantificadas e ressuspensas em meio de congelamento, sendo este composto por $90 \%$ SFB e $10 \%$ de DMSO, para posterior utilização em ensaios de co-cultura.

Para os ensaios de co-cultura com MCs autólogos, as células mononucleares foram descongeladas e ressuspendidas em meio IMDM-10, incubadas em estufa por 5 minutos, após, foram colocadas sobre $6 \mathrm{~mL}$ de Ficoll com o intuito de eliminar as células que não sobreviveram ao processo de congelamento. Assim, foram centrifugadas a $900 \mathrm{~g}$ por 30 minutos sem break, após, foram lavadas e isoladas usando o mesmo protocolo descrito acima, sendo que, no final do processo, as células foram ressuspendidas em meio IMDM-10 e colocadas em cultura, na concentração de $5 \times 10^{6}$ células $/ \mathrm{mL}$.

As células foram mantidas em estufa a $37{ }^{\circ} \mathrm{C}$ com saturação de $5 \%$ de $\mathrm{CO}_{2}$, por tempo overnight, para aderência em placas de plástico. Após esse período, as células não aderentes (CNAs) foram removidas e as células aderentes foram cultivadas por 7 dias em meio de cultura IMDM-10, contendo $50 \mathrm{ng} / \mathrm{mL}$ de GM-CSF (PeproTech Inc.) e 50ng/mL de IL-4 (PeproTech Inc.), em estufa, sob saturação de $5 \%$ de $\mathrm{CO}_{2}$ a $37^{\circ} \mathrm{C}$. No quinto dia de cultura, as células foram estimuladas para maturação com TNF- $\alpha$ na concentração de $50 \mathrm{ng} / \mathrm{mL}$ (PeproTech Inc.) ou foram plaqueados MCs autólogos (co-cultura sistema monolayer; representado pelo sinal “-”) ou sistema transwell (representado pelo sinal “/”), respeitando a proporção de 5 DCs : 1 MC. 
Assim, após dois dias de estímulo ou co-cultivo, as células foram removidas das placas, lavadas e sua viabilidade testada por Azul de Trypan 0,4\%. As células viáveis foram quantificadas e ressuspendidas com volume de meio estabelecido para os ensaios subsequentes.

3.6 Co-cultura de células dendríticas e mastócitos em monolayer.

Esse ensaio foi elaborado com o objetivo de analisar a interação célula-célula de MCs e DCs. Para tal, MCs gerados a partir do sangue periférico (descrito anteriormente) foram divididos em dois grupos experimentais, o primeiro grupo não sofreu nenhum tratamento (MCs), enquanto o segundo grupo foi cultivado com células da linhagem tumoral HCT-116 (MCT) previamente coradas com corante CFSE (InvitroGen ${ }^{\circledR}$ Molecular probe $^{\circledR}$ ), tal sistema respeitou a proporção de $1 \mathrm{MC}: 10 \mathrm{HCT}-116^{\mathrm{CFSE}}$ durante 24 horas. Transcorrido o período de co-cultura, as células da linhagem HCT-116 coradas com CFSE foram isoladas pela técnica de sorting em citômetro de fluxo (FACSAria ${ }^{\circ} \mathrm{BD}$ ). Os MCs sensibilizados com a linhagem tumoral (MCT) resultantes foram plaqueados com DCs imaturas (iDC) autólogas, sendo que a co-cultura respeitou a proporção de $1 \mathrm{MCT}$ : $5 \mathrm{iDCs}$, tal co-cultura foi mantida em meio IMDM-10 em estufa sob saturação de $5 \%$ de $\mathrm{CO}_{2}$ a $37^{\circ} \mathrm{C}$ por 2 dias. Posteriormente, as células foram removidas e analisadas quanto ao imunofenótipo e à capacidade linfoestimuladora das iDC.

\subsection{Avaliação da viabilidade celular por MTT pós-sorting.}

A avaliação da viabilidade celular das células expostas à separação por FACS-Aria (sorting) foi determinada pelo ensaio de microcitotoxicidade. Para tal, células sabidamente $\mathrm{CFSE}^{+}$(HCT-116) foram resuspendidas em R-10 e distribuídas em placas de fundo chato de 96 poços $\left(2 \times 10^{5}\right.$ células $\left./ \mathrm{ml}\right)$, assim, foram incubadas por 24 horas para a aderência celular. Em seguida, foi adicionado $100 \mu 1$ da solução de MTT (1 mg/ml; Sigma) e mantidas por mais 4 horas em estufa a $37{ }^{\circ} \mathrm{C}$. Após, foi removido o sobrenadante e os cristais de formazana solubilizados com $100 \mu \mathrm{l}$ de DMSO. Por fim, foi determinada a viabilidade celular pela densidade óptica adquirida em espectrofotômetro (VERSAmax tunable) a $540 \mathrm{~nm}$.

3.8 Co-cultura de células dendríticas e mastócito com restrição de contato (Transwell).

Com o intuito de avaliar a atividade dos produtos solúveis secretados pelos MCs sobre as DCs, utilizamos placas transwell de polietileno (Costar ${ }^{\circ}$ Corning) apresentando membranas com tamanho de poro de $0,4 \mu \mathrm{m}$ e diâmetro de membrana igual a $6,5 \mathrm{~mm}$. Nesse modelo, as 
DCs foram mantidas nos poços inferiores e os MCs (alogênicos) nos poços superiores separados pela membrana. As células foram co-cultivadas por 48 horas, em meio de cultura IMDM-10. Posteriormente, as células foram removidas e analisadas quanto ao imunofenótipo e à capacidade linfoestimuladora.

3.9 Imunofenótipo de células dendríticas por citometria de fluxo.

Após a co-cultura de MCs e DCs, as células foram retiradas dos poços e analisado o fenótipo apenas das células CD11 $\mathrm{c}^{+}$. Para tal, no mínimo, $2 \times 10^{5}$ células foram colocadas em tubos cônicos de $1,5 \mathrm{~mL}$, centrifugados por 30 segundo a $12.000 \mathrm{~g}$, a $4^{\circ} \mathrm{C}$. Então, foram adicionados aos tubos os anticorpos específicos, previamente titulados, para os marcadores de interesse: CD1a, CD11c, CD14, CD40, CD80, CD83, CD86, CCR7, PD-L1 e HLA-DR. Posteriormente, os tubos foram incubados por 20 minutos a $4^{\circ} \mathrm{C}$ com restrição de luz. Transcorrido o tempo, os tubos foram centrifugados e as células lavadas três vezes com 300 $\mu \mathrm{L} /$ tubo de tampão para citometria (PBS $-\mathrm{p} . \mathrm{H}=7,2$, contendo $0,5 \%$ de soro albumina bovina e $0,02 \%$ de azida sódica).

Após estas lavagens, as células foram ressuspendidas em $200 \mu \mathrm{L}$ de tampão para citometria e analisadas em citômetro (FACScantoII ${ }^{\circ} \mathrm{BD}$ ), utilizando-se o software FlowJo versão 8.7.2 (Three Star) para posterior análise.

3.10 Ensaio da proliferação de linfócitos T alogênicos co-cultivados com células dendríticas provenientes dos diferentes grupos experimentais.

Foram utilizados, aproximadamente, $10 \mathrm{~mL}$ de produto de câmara de leucorredução de doadores de plaquetas. Este foi diluído 1:2 em PBS e colocado sobre $12 \mathrm{~mL}$ de Ficoll-Paque para obtenção de células mononucleares. O material foi centrifugado a $900 \mathrm{~g}$ por 30 minutos, a $18^{\circ} \mathrm{C}$ sem breque. Posteriormente, a camada de células mononucleares formada foi retirada, colocada em outro tubo com RPMI- 1640, para nova centrifugação a 600g por 10 minutos. As células foram lavadas por mais 2 vezes a 400 e $200 \mathrm{~g}$. Após, as células foram plaqueadas em incubadas em estufa a $37^{\circ} \mathrm{C}$ sob saturação de $5 \%$ de $\mathrm{CO}_{2}$ por 2 horas. Após a aderência das células, as CNAs foram removidas e ressuspensas em meio de congelamento, contendo $90 \%$ SFB e $10 \%$ de DMSO.

Assim, para execução dos ensaios, as células foram descongeladas e incubadas em estufa por 5 minutos, após, foram colocadas sobre $6 \mathrm{~mL}$ de Ficoll com o intuito de eliminar as células que não sobreviveram ao processo de congelamento, assim, foram centrifugadas a 
900g por 30 minutos sem break, após, foram lavadas e isoladas usando o mesmo protocolo descrito acima. As células viáveis foram, então, separadas por separação imunomagnética (beads), em que o produto final era apenas $\mathrm{CD}^{+}$(Miltenyi Biotec Inc.). Em seguida, os linfócitos $\mathrm{T}$ foram incubados em tampão PBS-BSA $0,1 \%$ contendo $5 \mathrm{mM}$ de CFSE (Molecular probe ${ }^{\odot}$,InvitroGen). A incubação ocorreu a $37^{\circ} \mathrm{C}$, no escuro, por 10 minutos, após, foram acrescentado 2-5\% mL de IMDM-10 e incubados a $4^{\circ} \mathrm{C}$ por 5 minutos. Decorrido o tempo de incubação, as células foram lavadas 2 vezes em PBS (1x). Esses linfócitos T foram, então, co-cultivados com iDCs alogênicas sensibilizadas ou não com MCs (de todos os grupos experimentais) por um período de 5 dias, respeitamos a proporção de 10 linfócitos T: 1 iDC. Ao final da cultura, analisamos expressão de CD3, CD4, CD8 e CD25 presentes na membrana dos linfócitos e a diluição do corante CFSE destes. Para tal, utilizamos citômetro de fluxo (FACSCantoII ${ }^{\circ} \mathrm{BD}$ ), e software FlowJo versão 8.7.2 (Three Star) para posterior análise.

3.11 Detecção de citocinas por ensaio de citometria por beads (CBA).

Após 48 horas de co-cultura, os sobrenadantes de MC, MCT e iDCs foram avaliados por CBA quanto à presença das citocinas IL-6, IL-1 $\beta$, IL-10 e IL-8 (BD ${ }^{\odot}$ cat\# 552932). Em, em outro momento, verificamos a presença das citocinas IL-4, IL-6, IL-10, IL-17A, TNF$\alpha$, IL-12 e IFN- $\gamma\left(\mathrm{BD}^{\odot}\right.$ cat\#560484) após 5 dias da cultura de linfócito T alogêneicos com iDC provenientes das co-culturas com MCs. Brevemente, os sobrenadantes e os padrões de citocinas do kit foram incubados com microesferas de captura recobertas com anticorpos específicos para as respectivas citocinas e com o anticorpo de detecção marcado com ficoeritrina $(\mathrm{PE})$. Após as incubações de 3 horas no escuro à temperatura ambiente, foi acrescido $1 \mathrm{~mL}$ da solução de lavagem e o material centrifugado por 5 minutos a $200 \mathrm{~g}$. O sobrenadante foi desprezado e o botão ressuspendido em $300 \mu \mathrm{L}$ da solução de lavagem, por fim, a detecção das citocinas foi realizada em citômetro de fluxo (FACSCantoII ${ }^{\odot}$ BD). Os resultados analisados com auxílio do software BD FCAP Array v3.0.1.

3.12 Marcação intracelular.

Linfócitos T foram marcados para FoxP3, TGF- $\beta$ e IL-10; DCs foram marcadas para TNF- $\alpha$ e MCs para TGF- $\beta$.

Linfócitos foram removidos da placa após 5 dias de co-cultivo com os diferentes grupos experimentais de DCs. Assim, a suspensão foi centrifugada a $12.0000 \mathrm{rpm}$ por 30 
segundos, o sobrenadante descartado e no pellet foram adicionados $100 \mu \mathrm{L}$ de tampão PBSBSA $0,5 \%$, anti-CD3, anti-CD4 e anti-CD25, foram, então, mantidas por 20 minutos a $4^{\circ} \mathrm{C}$ no escuro. Transcorrido o tempo de marcação, as células foram lavadas com $500 \mu \mathrm{L}$ de tampão PBS-BSA 0,5\% e permeabilizadas utilizando o kit FoxP3/Transcription Factor Staining Buffer Set (Affymetrix $^{\circledR}$, e-Bioscience ${ }^{\circledR}$ ), portanto, para os processos de fixação e permebilização, seguimos as recomendações do fabricante. A frequência de IL-10 e TGF- $\beta$ produzido pelas células $\mathrm{T}$ foi analisada utilizando o ensaio proposto pelo kit Protein Transport Inhibitor assay (BD bioscience ${ }^{\odot}$, USA). Para tal, BD GolgiPlug ${ }^{\mathrm{TM}}$ (Brefeldina-A) foi adicionada na cultura e, após 6 horas de tratamento, as células foram removidas da placa e marcadas com anti-CD4, anti-CD25 (BD bioscience ${ }^{\complement}$, USA) e marcador de viabilidade (Live and dead, Life Technologies), assim, foram mantidas por 20 minutos a $4^{\circ} \mathrm{C}$ no escuro. Transcorrido o tempo de marcação, as células foram lavadas com $500 \mu \mathrm{L}$ de tampão PBSBSA $0,5 \%$. Após lavagem, as células foram fixadas e mantidas a $4^{\circ} \mathrm{C}$ por 24 horas. Transcorrido o tempo, as células foram ressuspendidas no tampão BD Perm/Wash (tampão de permeabilizarão e lavagem), e marcadas com anti-IL-10 e anti-TGF- $\beta$ (BD bioscience ${ }^{\circledR}$, USA).

As DCs $\left(\mathrm{CD} 11 \mathrm{c}^{+}\right)$e os $\mathrm{MCs}\left(\mathrm{CD} 117^{+}\right)$, após co-cultivo de 16 horas, foram removidos da placa e avaliada a produção de TNF- $\alpha$ e TGF- $\beta$, respectivamente. Para a detecção de TNF$\alpha$, as células foram tratadas com Brefeldina-A por 15 horas, enquanto, para TGF- $\beta$, o tratamento foi de 6 horas. Para ambas as marcações, as células foram removidas após 16 horas totais de co-cultivo e marcadas com anti-CD11c, anti-CD117 (BD bioscience ${ }^{\complement}$, USA) e marcador de viabilidade (Live and dead, Life Technologies), assim foram mantidas por 20 minutos a $4^{\circ} \mathrm{C}$ no escuro. Transcorrido o tempo de marcação, as células foram lavadas com $500 \mu \mathrm{L}$ de tampão PBS-BSA 0,5\%. Após lavagem, as células foram fixadas (BD Cytofix/Cytoperm $\left.{ }^{T M}\right)$, após fixação, foram lavadas duas vezes e mantidas em tampão PBSBSA $0,5 \%$, a $4^{\circ} \mathrm{C}$ por 24 horas. Transcorrido o tempo, as células foram ressuspendidas no tampão BD Perm/Wash e marcadas com anti-TNF- $\alpha$ ou anti-TGF- $\beta$.

Para análise, foram adquiridos, no mínimo, 20.000 eventos/gate, utilizando o citômetro de fluxo FACScantoII ${ }^{\circ}$ BD (Becton Dickinson, USA) e as analyses foram feitas utilizando o software FlowJo versão 8.7.2 (Three Star). 
3.13 Ensaio de supressão da proliferação de linfócitos T alogênicos.

Células dendríticas foram geradas e co-cultivadas com MCs - descrito acima - após dois dias de co-cultivo as células foram removidas da cultura e quantificadas, assim, replaquedas com linfócitos $\mathrm{CD}^{+}$alogênicos, previamente separados por beads, permaneceram nestas condições por 5 dias. Transcorrido o tempo de co-cultivo, as células foram removidas, quantificadas e isoladas por separação imunomagnética, sendo obtidas as células $\mathrm{CD} 3^{+} \mathrm{CD} 4^{+} \mathrm{CD} 25^{+}$(seleção negativa para $\mathrm{CD} 4^{+}$e positiva para $\mathrm{CD} 25^{+}$). Estas células foram, então, plaqueadas junto com Linfócitos $\mathrm{T}$ naïve alogênicos isolados por separação imunomagnética, previamente corados com Cell Trace Violeta (CTV), 2,5 mM (Molecular probe ${ }^{\mathscr{O}}$ InvitroGen). Tal co-cultura respeitou a proporção de 1 linfócito $\mathrm{T} \mathrm{CD}^{+} \mathrm{CD} 25^{+}$ (efetor): 1 linfócito $\mathrm{T} \mathrm{CD}^{+}$naïve (alvo) ou 1 linfócito $\mathrm{T} \mathrm{CD} 4^{+} \mathrm{CD} 25^{+}$(efetor): 5 linfócito $\mathrm{T}$ $\mathrm{CD}^{+}$nä̈ve (alvo).

Com o intuito de estimular os linfócitos e, assim, averiguar se as células $\mathrm{T}$ $\mathrm{CD} 4^{+} \mathrm{CD} 25^{+}$provenientes do co-cultivo com iDC-MC ou iDC/MC seriam capazes de suprimir a proliferação de linfócitos T nä̈ve, estimulamos as células com 1\% volume/volume de fitohemaglutinina (PHA). Após 3 dias de cultivo, as células foram removidas da placa e transferidas para tubos de microcentrifugação (eppendorf) e lavadas três vezes com 300 $\mu \mathrm{L} /$ tubo de tampão para citometria (PBS - p.H=7,2, contendo $0,5 \%$ de soro albumina bovina e $0,02 \%$ de azida sódica). Após estas lavagens, as células foram ressuspendidas em $200 \mu \mathrm{L}$ de tampão para citometria e a diluição do CTV foi analisadas em citômetro de fluxo FACScantoII ${ }^{\odot}$ BD), utilizando o software FlowJo versão 8.7.2 (Three Star) para análise.

\subsection{Análise da liberação de grânulos por marcação de CD107a de membrana.}

A mobilização do CD107a para a superfície das células da linhagem de mastocitoma humano, HMC-1.1, foi avaliada após a cultura in vitro de HMC-1.1 na ausência ou presença de estímulo de desgranulação, sendo este PMA (controle positivo) ou após co-cultivo com iDCs. Para tal, as células foram lavadas três vezes com IMDM e ressuspensas em meio de cultura IMDM-10. A viabilidade das células foi avaliada utilizando corante de exclusão de azul de Trypan blue para discriminar entre células vivas e mortas. A concentração celular foi ajustada para $2 \times 10^{6}$ células $/ \mathrm{mL}$ em meio de cultura celular contendo os estímulos citados, brefeldina A (1 $\mu \mathrm{L} / \mathrm{mL}$, BD Pharmingen) e anti-CD107a (BD Pharmingen). As células foram 
cultivadas em placas de 96 poços de fundo arredondado (Corning ${ }^{\odot}$ Constar) a $37^{\circ} \mathrm{C}$ com saturação de $5 \%$ de $\mathrm{CO}_{2}$. Depois de 12 horas de incubação, as células foram removidas e marcadas com anti-CD117 a $4^{\circ} \mathrm{C}$ durante 20 minutos. Assim, foram centrifugadas a $12.000 \mathrm{~g}$ por 30 segundos e analisada a mobilização de CD107a por citometria de fluxo (FACScantoII ${ }^{\circledR}$ BD), para análise dos resultados, utilizamos o software FlowJo versão 8.7.2 (Three Star).

\subsection{Influxo de Cálcio.}

Células da linhagem de mastocitoma humano (HMC-1.1) foram suspendidas em tampão PBS-BSA 0,5\% (10 células/100 $\mu \mathrm{L})$, e adicionados $1 \mu \mathrm{M}$ de Fluo-4AM (Molecular Probes $^{\circledR}$, Life Technologies). Após, as células foram mantidas em "banho-Maria" a $28^{\circ} \mathrm{C}$ por 30 minutos. Transcorrido o tempo de incubação, as células foram lavadas com $5 \mathrm{~mL}$ de tampão PBS-BSA $0,5 \%$ por duas vezes e resuspendidas em tampão de $\mathrm{Ca} 2^{+}\left(10^{6}\right.$ células $\left./ \mathrm{mL}\right)$.

Após marcação, as células HMC-1.1 foram adquiridas em um FACSCanto II $^{\circledR}$ BD por 60 segundos, em seguida, foram desafiadas com os diferentes estímulos, sendo IMDM-10 o controle negativo de desgranulação e ionomicina, o controle positivo de desgranulação, assim que desafiadas, as células foram prontamente adquiridas por mais 240 segundos. Os dados foram analisados utilizando a opção kinetics do software FlowJo versão 8.7.2 (Three Star).

\subsection{Imunoflorescência}

DCs foram retiradas da placa de cultura e centrifugadas por 10 minutos a $300 \mathrm{~g}$, após o pellet de células, foi ressuspendido em $500 \mu \mathrm{L}$ ( $10^{7}$ células) de PBS-BSA 0,5\% pré-aquecido e acrescidos $1,1 \mu \mathrm{L}$ do Cell Trace Orage $(10 \mathrm{mM})$ (Molecular probe ${ }^{\complement}$ InvitroGen), assim, as células foram mantidas por 15 minutos a $37^{\circ} \mathrm{C}$ com restrição à luz. Decorrido o tempo, as células foram lavadas com $10 \mathrm{~mL}$ de IMDM e mantidas à temperatura ambiente por 30 minutos. Após, as células foram ressuspendidas em IMDM-10 e plaqueadas em placa de petri (60 x $15 \mathrm{~mm}$ ), depois de 1 hora, as células foram desafiadas com MCTs autólogos previamente marcadas com anti-FCeRI $\alpha$ e filmadas por 1 horas.

Células da linhagem HMC-1.1 foram lavadas com $300 \mu \mathrm{L}$ do tampão PBS-BSA 0,5\% duas vezes, após lavagem, as células foram marcadas com anti-CD13 e anti-PD-1, e mantidas a $4^{\circ} \mathrm{C}$ por 20 minutos. Transcorrido o tempo, foi adicionado $1 \mathrm{~mL}$ do tampão PBS-BSA $0,5 \%$ e a suspensão foi centrifugada a $12.000 \mathrm{rpm}$ por 30 segundos. Assim, após centrifugação, as células foram resuspendidas em $100 \mu \mathrm{L}$ de Prolong ${ }^{\mathrm{R}}$, este é composto também pelo corante 
DAPI responsável pela marcação nuclear, então, $10 \mu \mathrm{L}$ da suspensão foram transferidos para uma lâmina de microscopia. Sobre a lâmina, foi colocada uma lamínula devidamente higienizada. As imagens foram obtidas em Microscópio confocal multifótons (Zeiss LSM-780 NLO).

3.17 PCR quantitativo em tempo real (qPCR) para análise da expressão de indoleamina 2,3deoxigenase.

\subsubsection{Extração do RNA das células dendríticas}

Após 24 horas de co-cultivado dos mastócitos (HMC.1.1) com iDCS, aproximadamente, $2 \times 10^{5}$ células dendríticas $\left(\mathrm{CD} 11 \mathrm{c}^{+}\right)$foram separadas por separação imunomagnéticas e submetidas ao protocolo de extração de RNA pela metodologia de Trizol; em que as células foram resuspendidas em $1 \mathrm{~mL}$ de Trizol, após adição do reagente, homogeneizamos a suspensão por flush com auxílio de pipetas de $1000 \mu \mathrm{L}$, depois, as amostras permaneceram à temperatura ambiente (TA) por 5 minutos.

Transcorrido o tempo, foram adicionados $200 \mu \mathrm{L}$ de clorofórmio, assim, as amostras foram submetidas à agitação vigorosa por 15 segundos e mantidas a TA por 3 minutos. Em seguida, as células foram centrifugadas a $12.000 \mathrm{~g}$ por 15 minutos, sendo a temperatura da centrífuga igual a $4^{\circ} \mathrm{C}$. Após centrifugação, foi coletada apenas a porção incolor da amostra.

Esta porção foi, então, transferida para um novo microtubo de $1 \mathrm{~mL}$ e adicionados 500 $\mu \mathrm{L}$ de álcool isopropílico. Em seguida, o tubo foi vertido 3 vezes e incubado à temperatura ambiente por 15 minutos. Após, a amostra foi centrifugada a 12.000 g por 10 minutos, sendo a temperatura da microcentrífuga igual a $4^{\circ} \mathrm{C}$.

Então, o sobrenadante foi removido e o pellet suspenso em etanol 75\% (diluído em água DEPEC) e centrifugada a $7.500 \mathrm{~g}$ por 5 minutos. Em seguida, as amostras foram incubadas à temperatura ambiente até secagem do pellet, enfim, foram quantificadas pelo espectrofotômetro NanoDrop ND-1000 a $260 \mathrm{~nm}$.

\subsubsection{Obtenção do DNA complementar}

Para obtenção do cDNA (DNA complementar), 1,2 $\mu \mathrm{g}$ do RNA extraído foi submetido à transcrição reversa num volume final de $19 \mu \mathrm{L}$, usando a enzima transcriptase reversa SuperScriptTM III (Invitrogen) (200 U/mL). O RNA foi diluído em água RNAout, e, nesta diluição, foram adicionados $1 \mu \mathrm{L}$ de oligo(dT) primer $(0,5 \mu \mathrm{g} / \mu \mathrm{L}), 4 \mu \mathrm{L}$ de tampão $(5 \mathrm{X}), 2 \mu \mathrm{L}$ 
de mix de dNTPs $(2,5 \mathrm{mM}), 1 \mu \mathrm{L}$ de DTT $(0,1 \mathrm{M})$ e $1 \mu \mathrm{L}$ da enzima transcriptase reversa. A reação foi incubada a $70^{\circ} \mathrm{C}$ por 5 minutos, $25^{\circ} \mathrm{C}$ por 10 minutos. Nesta etapa, adicionamos 8 $\mu \mathrm{L}$ MIX por amostra, $42^{\circ} \mathrm{C}$ por 1 hora e 15 minutos, $70^{\circ} \mathrm{C}$ por 15 minutos, por fim, $4{ }^{\circ} \mathrm{C}$ (hold).

\subsubsection{PCR quantitativa}

Pares de oligonucleotídeos iniciadores exônicos, para os genes IDO1 (F: GTGCAGGCCAAAGCAGCG/R: CCGCAGGCCAGCATCACCT) e $\beta$-actina (F: CAGGCACCAGGGCGTGATGG/R:CGATGCCGTGCTCGATGGGG) foram desenhados com base em sequências referências depositadas no NCB (http://www.ncbi.nlm.nih.gov) com o auxílio do website Primer Bank (http://pga.mgh.harvard.edu/primerbank/índex.html). As reações da qPCR das amostras de células dendríticas $\left(\mathrm{CD} 11 \mathrm{c}^{+}\right)$ocorreu da seguinte maneira: primeiramente, foram adicionados 6,25 $\mu \mathrm{L}$ de SYBR Green PCR Master Mix (Applied), 4,25 $\mu \mathrm{L}$ de água RNAout, $0,375 \mu \mathrm{L}$ de cada iniciador $(10 \mathrm{pmol} / \mu \mathrm{L})$ e $1 \mu \mathrm{L}$ de cDNA (na diluição 1:50). As condições para a reação foram: $95^{\circ} \mathrm{C}$ por 10 minutos para a ativação da enzima AmpliTaq Gold DNA Polimerase presente no SYBR mix, 40 ciclos de desnaturação a $95^{\circ} \mathrm{C}$ por 15 segundos e anelamento e extensão a $60^{\circ} \mathrm{C}$ por 1 minuto, seguido da curva de dissociação $\left(95^{\circ} \mathrm{C}\right.$ por 1 minuto, $60^{\circ} \mathrm{C}$ por 30 segundos e $95^{\circ} \mathrm{C}$ por 30 segundos). A reação de qPCR foi realizada no equipamento Stratagene Mx3000P QPCR System e a aquisição dos resultados pelo software MxProTM 3.0. A expressão relativa dos gene-alvo foi analisada pelo método do $2^{-\Delta \Delta \mathrm{CT}}$, na qual o $\mathrm{CT}=$ valor limiar de fluorescência; $\Delta \mathrm{CT}=\mathrm{CT}$ do gene-alvo $-\mathrm{CT}$ dos genes house-keepings ( $\beta$-actina); $\Delta \Delta \mathrm{CT}=\Delta \mathrm{CT}$ do gene-alvo nas amostras - $\Delta \mathrm{CT}$ do

gene-alvo nos controles (iDCs sem tratamento). Por fim, calculamos o valor de $2^{-\Delta \Delta \mathrm{Ct}}$, por conseguinte, obtivemos a expressão relativa de determinado gene de interesse.

3.18 Marcação de Indoleamina 2,3-deoxigenase (IDO) por citometria de fluxo.

As células (DCs e MCs) foram removidas de cultura após 16 horas de co-cultivo, lavadas duas vezes com tampão PBS-BSA 0,5\%, e, então, foi adicionado marcador de viabilidade celular (Live and dead $^{\complement}$ Life Technologies), anti-CD11c e anti-CD117 (BD Bioscience, EUA). Em seguida, as células foram permeabilizadas (segundo procotolo usado para avaliação FoxP3). Após permeabilização, as células foram lavadas por duas vezes com PBS-BSA $0,5 \%$ e adicionados soro de camundongo ( $2 \%$ volume/volume) e, após 15 minutos, foi adicionado anti-IDO ( $1 \mu \mathrm{g} / 10^{6}$ células, Abcam, EUA ). As células foram mantidas por 40 minutos, a $37^{\circ} \mathrm{C}$, em câmara úmida. Transcorrido o tempo, as células foram lavadas com PBS 
e foi adicionado anticorpo secundário conjugado com Alexa 633 (anticorpo de cabra anticamundongo, eBiosciences). Depois de mais 40 minutos de incubação, as células foram centrifugadas a 12.000 g por 30 segundos e analisadas em citômetro FACScantoII ${ }^{\circledR}$ BD, utilizando o software FlowJo versão 8.7.2 (Three Star).

3.19 Marcação intracelular de STAT-3 fosforilada.

Após 24 horas de co-cultivo (iDC e MC), as células foram removidas da placa e submetidas à fixação, para tal, as células foram ressuspendidas em BD Cytofix/Cytoperm ${ }^{T M}$ Buffer (BD Pharmigen ${ }^{\mathrm{TM}}$ ) e incubadas a $4^{\circ} \mathrm{C}$ por 30 minutos. Em seguida, as células foram lavadas com PBS e, então, permeabilizadas com $90 \%$ metanol gelado e mantidas a $-20{ }^{\circ} \mathrm{C}$. Após 40 minutos, a suspensão foi centrifugada e as células ressuspendidas em PBS, e marcadas com anticorpo primário anti-STAT-3 fosforilado (pSTAT-3) (Tyr 705) e incubadas por 20 minutos a $4^{\circ} \mathrm{C}$. Após, as células foram lavadas com $300 \mu \mathrm{L}$ de PBS e ressuspendidas em tampão PBS-BSA 0,5\% com formaldeído $2 \%$.

Os dados foram obtidos em citômetro FACSCantoII ${ }^{\odot} \mathrm{BD}$, em que foram adquiridos, no mínimo, 30.000 eventos por amostra, para a análise utilizando-se o software FlowJo versão 8.7.2 (Three Star).

\subsection{Avaliação de STAT-3 e pSTAT-3 por Western Blot.}

\subsubsection{Extração de proteínas totais}

Para a extração de proteínas, o pellet de células foi lavado com PBS suplementado com Fluoreto de Sódio (Naf) (500 mM), cocktail de inibidores de fosfatase (PiC), ortovanadato de sódio e fluoreto de fenilmetilsulfonilo (PMSF). Assim, foram centrifugados a $500 \mathrm{~g}$ por 5 minutos. Transcorrido o tempo, o sobrenadante foi retirado e acrescido tampão RIPA, sendo este o volume três vezes maior que o pellet, suplementado com os inibidores da fosfatase, ETDA $(2 \mathrm{mM})$ e EGTA. As amostras foram mantidas em freezer $-80^{\circ} \mathrm{C}$. A concentração proteica das amostras foi determinada, posteriormente, pelo ensaio colorimétrico baseado na redução de $\mathrm{Cu} 2^{+}$para $\mathrm{Cu}^{+}$por proteína em meio alcalino, para tal, o teste utiliza o ácido bicinconínico (BCA) (Pierce ${ }^{\mathrm{TM}}$ BCA Protein Assay Kit, Thermo Fisher).

\subsubsection{Western Blot}

Após quantificação $20 \mu \mathrm{g}$ da amostra, foi adicionado em gel SDS-PAGE a 10\% no final da corrida em tampão de corrida, as proteínas foram transferidas por transferência úmida 
(400V por 2 hora) para uma membrana de difluoreto de polivinilo (PVDF), previamente ativada pelo tratamento com $100 \%$ de metanol. Após transferência, a membrana foi lavada uma vez com água miliQ por 5 minutos, depois, com tampão TBST (20 mM Tris-Base e 01\% Tween20) sob agitação constante por 15 minutos à temperatura ambiente. Após três lavagens, para o bloqueio da membrana, foi adicionado $5 \%$ de leite desnatado dissolvido em água MiliQ (solução de bloqueio), mantida à temperatura ambiente por 1 hora e com agitação constante. Decorrido o tempo de bloqueio, a membrana foi lavada por mais três vezes com TBST nas mesmas condições citadas. Em seguida, a membrana foi incubada overnight com o anti-STAT-3 (1:5.000), anti-pSTAT-3 (1:5.000) ou $\beta$-actina (1:30.000), a $4^{\circ} \mathrm{C}$, sob agitação constante. Depois disso, o anticorpo primário foi retirado e a membrana foi lavada com TBST por 15 minutos sob agitação constante. Após três lavagens, a membrana foi incubada com anticorpo secundário $(1: 10.000)$ conjugado à peroxidase e diluído em solução de bloqueio. Depois de 1 hora de incubação, a membrana foi lavada três vezes com TBST por 15 minutos sob agitação constante. Em seguida, incubada por 5 minutos com a solução reveladora West Pico (Thermo Fisher), para posterior revelação no aparelho GBox.

\subsection{Análise estatística.}

A análise estatística dos dados foi realizada por análise de variância (ANOVA), seguida do teste de Tukey para comparações múltiplas quando a amostra for paramétrica ou análise por Kruskal-Wallis, seguida pelo método de Dunn quando a amostra não for paramétrica, ou pelo teste $\mathrm{T}$ de Student não paramétrico (indicado no ensaio), sendo consideradas significantes as diferenças cujas probabilidades de erro forem menores que 5\% $(\mathrm{p}<0.05)$. 
4 RESULTADOS 


\section{RESULTADOS}

\subsection{Padronizações e validação dos resultados}

\subsubsection{Reação em cadeia da polimerase para detecção de contaminação por micoplasma.}

Micoplasma (Mollicutes) são bactérias capazes de infectar plantas, insetos e animais, aquelas podem representar um problema para a pesquisa, pois são capazes de infectar linhagens celulares e, com isso, causar diminuição dos nutrientes presentes no meio de cultura; assim, podem interferir no metabolismo das células estudadas, o que pode resultar em alterações dos resultados (Miller et al., 2003).

Portanto, tanto a linhagem HCT-116, câncer colorretal humano, bem como as linhagens HMC-1.1 e HMC-1.2, mastocitoma humano foram submetidas a um protocolo de PCR para amplificação do gene da subunidade $16 \mathrm{~S}$ do RNA ribossomal de micoplasma, ureaplasma e spiroplasma. Foram utilizados os genes GPO3 $\left(5^{\text {ee }}\right.$ GGGAGCAAACAGGATTAGATACCCT-3 $3^{\text {ee }}$-forward) e MGSO $\quad\left(5^{\text {ee }}\right.$-TGCACC ATCTGTCACTCTGTTAACCTC-3e- reverse), sendo o produto esperado de $270 \mathrm{pb}$. Como esperado, as células não estavam infectadas com o Micoplasma sp., o que pode validar nossos resultados em relação à linhagens (Figura 1).

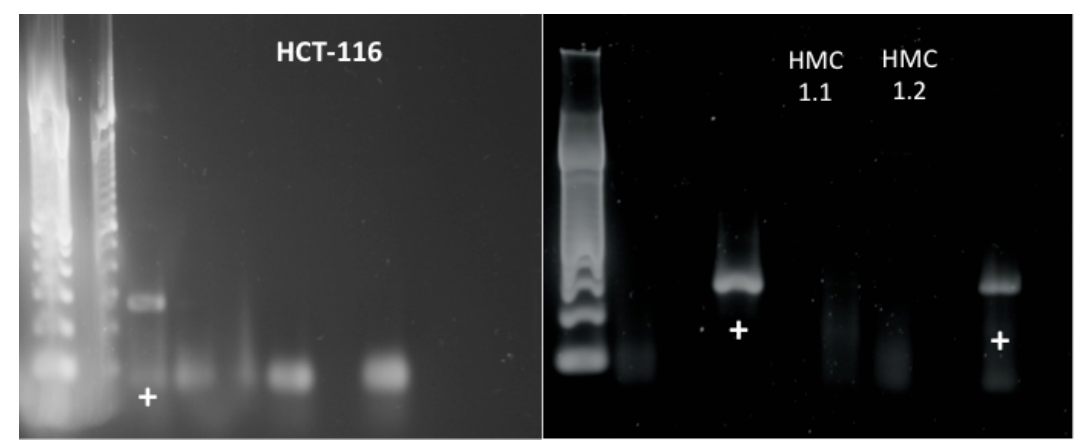

Figura 1. Análise da ausência de Micoplasma sp nas culturas celulares utilizadas no trabalho. Figura demonstrativa da PCR para análise da subunidade 16S do RNA ribossomal de micoplasma, ureaplasma e spiroplasma. Para tal, foram utilizados os genes GPO3 (forward) e MGSO (reverse), sendo o produto esperado (quando infectado) de $270 \mathrm{pb}$, esses representados pelo sinal de + . Logo, podemos notar que, nos poços referentes à linhagem de CCR (HCT-116) e de mastocitomas (HMC-1.1 e HMC-1.2), não há o aparecimento da banda.

\subsubsection{Avaliação da diferenciação de DC em meio de cultura IMDM-10}

As células dendríticas (DCs) são as principais células apresentadoras de antígeno (APC), assim, uma das principais funções das DCs é responder prontamente a mudanças do 
microambiente. Com o intuito de averiguar se mudança do meio de cultura para IMDM-10 e não R10 (comumente utilizado pelo grupo) poderia alterar a diferenciação de monócitos em DCs, bem como a maturação destas células, nosso primeiro passo foi descongelar PBMCs e diferenciá-las na presença de ambos os meios de cultura.

Ambos, R-10 e IMDM-10, foram capazes de sustentar a diferenciação de monócitos em DCs, sendo esta analisada pela marcação com azul de Trypan $0,4 \%$ e corante comercial Live and dead (Life Technologie ${ }^{\odot}$ ), além da expressão de HLA-DR, CD11c, CD1a, CCR7, CD40, CD123, CD83, CD80, CD86, PDL1 e CD14 (dados não mostrados). No quinto dia de cultura, foram adicionados $5 \mu \mathrm{L}$ de TNF- $\alpha(50 \mathrm{ng} / \mathrm{mL})$ e, depois de dois dias, analisamos a expressão dos mesmos marcadores com o intuito de validar a maturação destas células, bem como, sua viabilidade. Conforme o esperado, tanto as células imaturas (iDC) quanto as maduras (mDC) estavam viáveis ao fim da cultura $(84,6 \pm 1,2 \%$ iDC e $86,8 \pm 2,6 \%$, Life and $\operatorname{dead}^{\text {neg }}$ ) (Figura 2A), portanto, mesmo depois do congelamento e da manutenção em IMDM10, as DCs permaneceram viáveis durante todo o período de cultura. Após, analisamos se a diferenciação e maturação também ocorreu em meio IMDM-10. Como demonstrado na Figura 2B ao fim da cultura, obtivemos células iDC e mDC (após estímulo), evidenciado pelo aumento significativo da frequência das moléculas HLA-DR $(91,7 \pm 7,1 \%$ vs $97,4 \pm 3,4 \%)$, $\operatorname{CCR} 7(63,5 \pm 13,7 \%$ vs $81,5 \pm 4,4 \%)$ e $\operatorname{CD} 83(7,2 \pm 6,5 \%$ vs $29,3 \pm 3,6 \%)$, associado à diminuição também significativa de CD123 (19,6 \pm 9,8\% vs 6,4 \pm 6,7\%), PD-L1 (43,8 \pm $21,3 \%$ vs $33 \pm 5,5 \%)$ e CD14 (41,4 $\pm 5,5 \%$ vs 8,3 \pm 7,6\%) em mDC. Quanto à intensidade de fluorescência, observamos aumento significativo de CD86 (10,4 \pm 0,5\% vs 28,7 $\pm 12,8 \%$ ) e uma tendência de aumento da molécula CD80, validando, assim, os aspectos de maturação das DC, e confirma que o cultivo em IMDM-10 é capaz de sustentar tanto a diferenciação quanto a maturação destas células. 


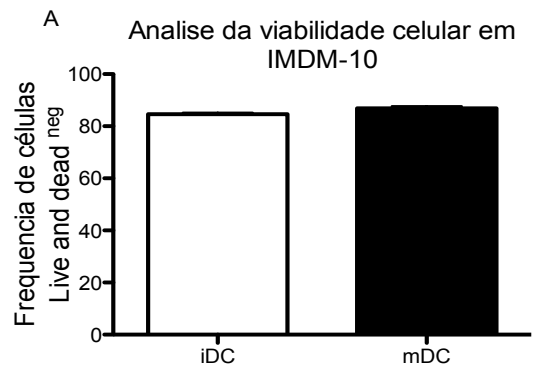

Padronização diferenciação e maturação de mo-DC em meio IMDM-10\%
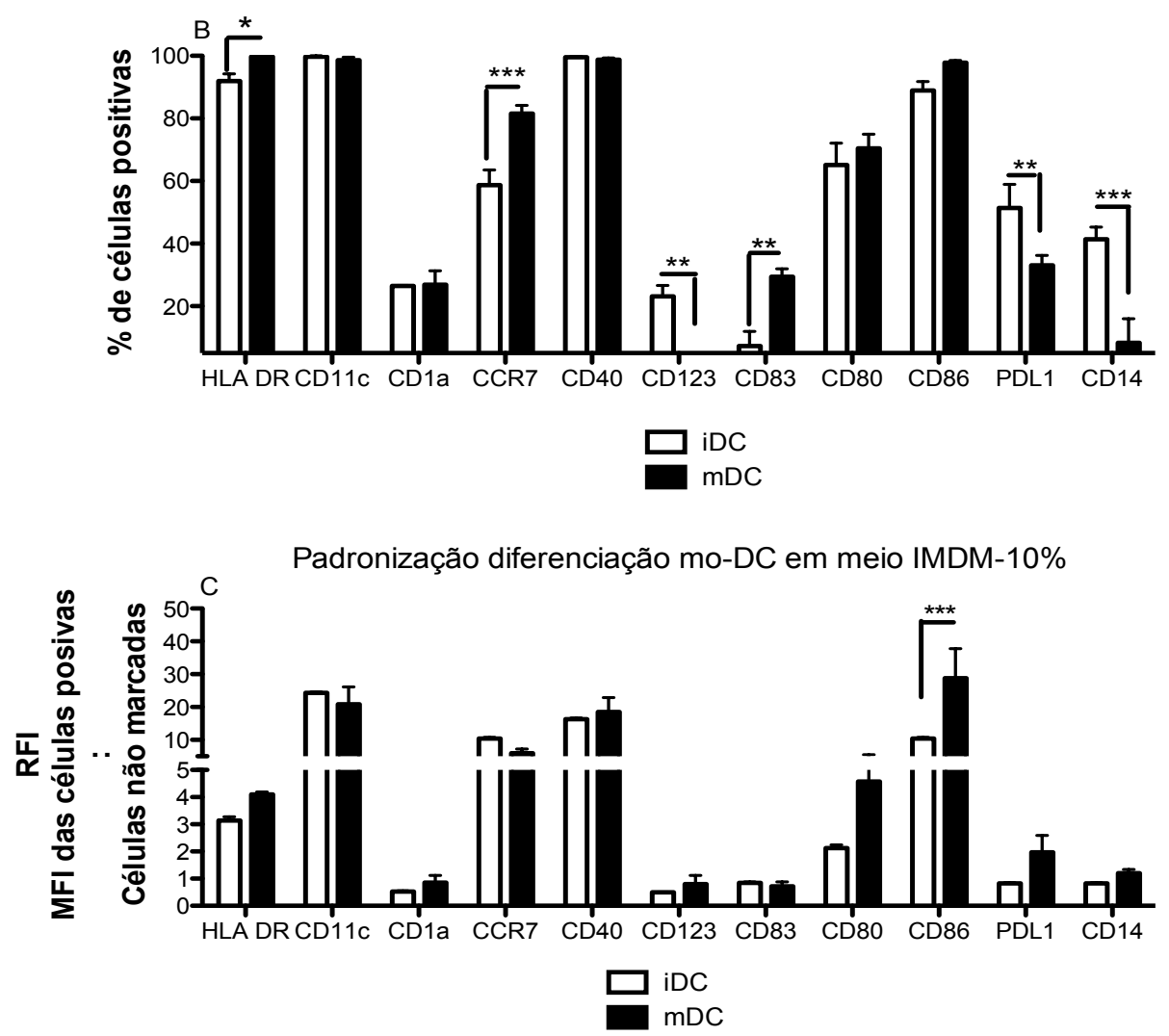

Figura 2. Validação da viabilidade, capacidade de diferenciação e maturação em meio IMDM-10. Células mononucleares do sangue de paciente foram separadas por gradiente de Ficoll, em seguida, plaqueadas para aderência (overnight). Em seguida, as células não aderentes foram retiradas e as células aderentes estimuladas com GM-CSF (50 ng/mL) e IL-4 (50 ng/mL). Após 5 dias, as células foram estimuladas com $50 \mathrm{ng} / \mathrm{mL}$ de TNF$\alpha$ para sua maturação (mDC) ou mantidas no estado imaturo (iDC). Depois de 2 dias analisamos a viabilidade de ambas as células bem como a expressão dos marcadores. Em (A) demonstramos a viabilidade celular de iDC e mDC. Em (B) observamos a frequência de expressão de moléculas associadas à diferenciação e maturação de DCs derivadas in vitro a partir de monócitos presentes no sangue periférico tanto em iDC, quanto mDC; (C) Representação gráfica do índice de fluorescência relativa, sendo este calculado pela razão do MFI das células positivas pelo MFI das células não marcadas. Para análise estatística, foi utilizado ANOVA, seguida pelo teste de Tukey, sendo considerado significativo quando $\mathrm{p}<0,05\left(^{*}\right), \mathrm{p}<0,01(* *)$ e $p<0,001(* * *)$. Dados referentes a três experimentos independentes. 


\subsubsection{Diferenciação de Mastócitos in vitro}

Células mononucleares obtidas a partir do sangue periférico de doadores (plaquetoferese) foram quantificadas e separadas. Estas passaram por separação por coluna magnética, em que foram isoladas apenas as células $\mathrm{CD} 34^{+}$, esta separação teve pureza de, aproximadamente, $40 \%$ de eventos totais (Figura 3 ).
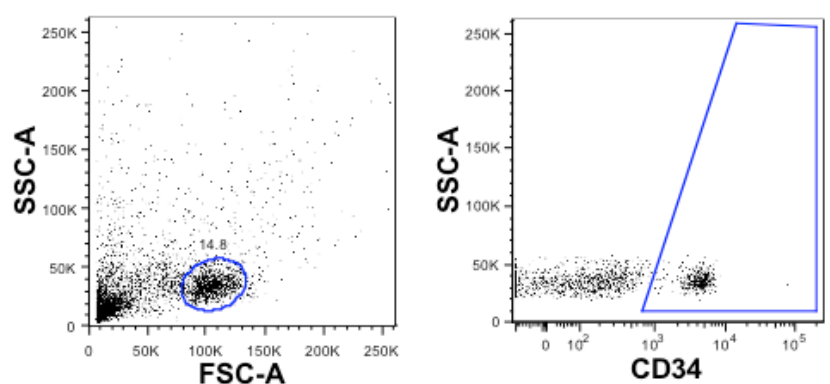

Figura 3. Dot-Plots representativos da separação de células tronco $\mathrm{CD}^{+}{ }^{+}$por seleção imunomagnética positiva. Análise de tamanho e granulosidade (FSC vs SSC) das células presentes na suspensão obtidas após separação imunomagnética, bem como a expressão de $\mathrm{CD} 34^{+}( \pm 40 \%)$, foram adquiridos, no mínimo, 30.000 eventos dentro do gate indicado em SSC-A versus FSC-A (n=3).

As células resultantes da separação foram, então, submetidas ao processo de diferenciação proposto por Saito et al. (Saito et al., 2006). Como esperado, após 56 dias de cultivo, pudemos obter uma cultura enriquecida de MCs (Figura 4), evidenciada pela coloração de grânulos intracelulares após tratamento com azul de toluidina, tais grânulos não foram observados em células não diferenciadas (PBMC totais) (Figura 5). 

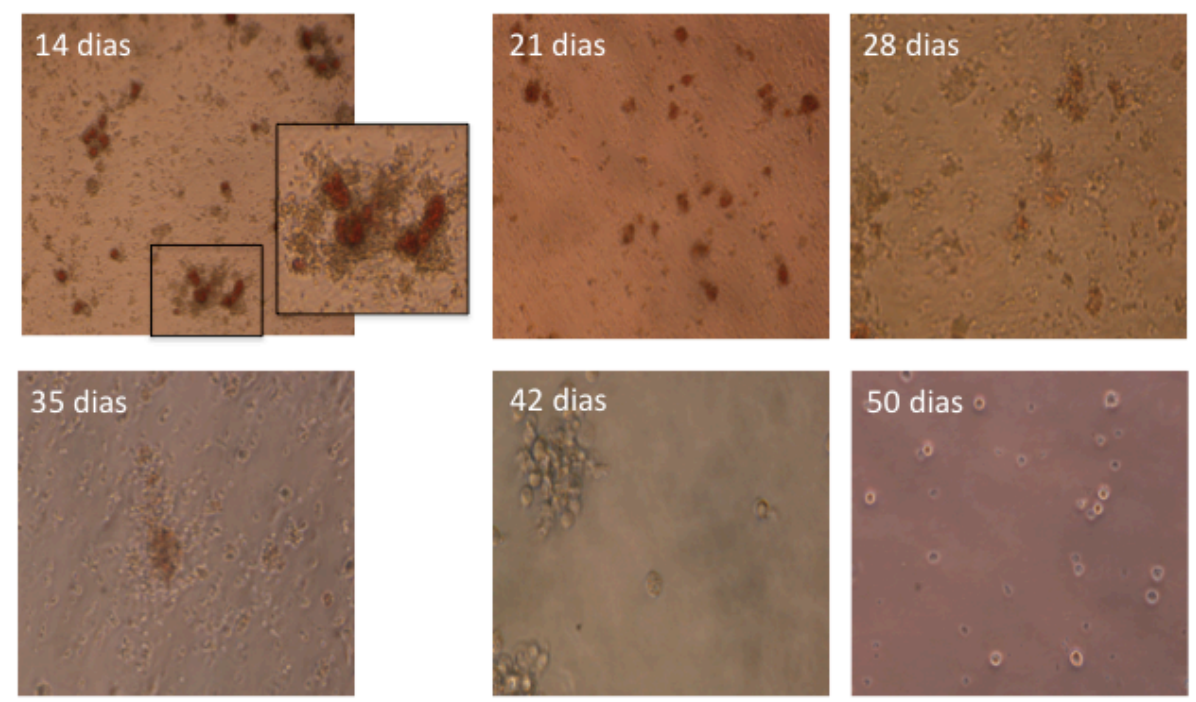

$10 x$

Figura 4. Fotografia representativa da progressão na diferenciação de $\mathrm{CD}^{+} 4^{+}$em $\mathrm{MCs}$. Cada foto representa as populações presentes nos respectivos dias de cultivo. Inicialmente, podemos observar a formação de colônias após 14 dias de cultivo,sendo que estas permaneceram presentes até o $28^{\text {th }}$ dia de cultura. Após 35 dias de cultivo, observamos a desagregação das colônias e, após uma semana, o aparecimento de células maiores e granulosas, estas células foram retiradas das placas, centrifugadas a $650 \mathrm{~g}$ por 10 minutos e ressuspendidas em $1 \mathrm{~mL}$ de IMDM suplementado com $100 \mu \mathrm{L}$ de PBS-BSA 10\%, $100 \mu \mathrm{L}$ de insulina-transferrina-selênio (solução estoque), IL-6 $(50 \mu \mathrm{g} / \mathrm{mL})$ e SCF $(100 \mu \mathrm{g} / \mathrm{mL})$, e replaquedas em placas de 6 seis poços. Após oito dias, pudemos observar ausência de colônias celulares e a presença de células com características morfológicas semelhantes à de MCs.

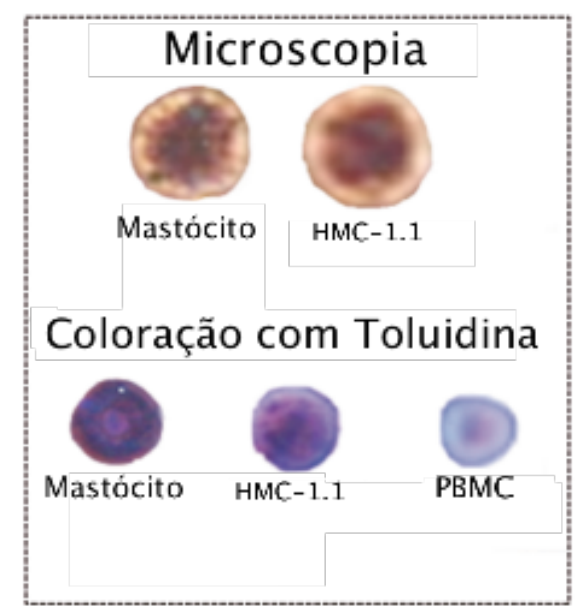

Figura 5. Fotografias representativas da morfologia de mastócitos (MC) diferenciados in vitro e linhagem de mastocitoma HMC-1.1, abaixo, demonstração da marcação de grânulos intracelulares por azul de toluidina. Conforme demonstrado na figura, por microscopia de fase (convencional), pudemos observar a presença de grânulos intracelulares tanto na cultura de células diferenciadas in vitro quanto na linhagem de mastocitoma humano. Ainda, com o intuito de verificar a presença de grânulos intracelulares, após 50 dias de cultura, as células foram marcadas com azul de Toluidina, como apresentado nas fotografias superiores, podemos observar a presença destes nas células diferenciadas in vitro, no entanto, não observamos o mesmo em PBMC (fotografias inferiores) aumento de 40x e 10x, respectivamente. 
Além disso, por citometria de fluxo, observamos que a maioria das células perdeu as características de células $\mathrm{CD}^{+} 4^{+}$e passou a expressar CD13 $(91,40 \pm 2,9 \%)$ em sua membrana, sendo esta uma molécula de superfície capaz de caracterizá-las como células do compartimento mieloide. Dentre as células CD13 positivas, 95,85 $\pm 1,4 \%$ eram, também, positivas para CD117 (c-kit/SCF-R) e 57,58 $\pm 5,77 \%$ eram positivas para FCERI $\alpha$ (receptor de alta afinidade de $\operatorname{IgE}$ ) demonstrando que a diferenciação ocorreu com sucesso. Além disso, dentre as células CD13 ${ }^{+}, 99,12 \pm 0,6 \%$ expressavam CD33 (Figura 6).

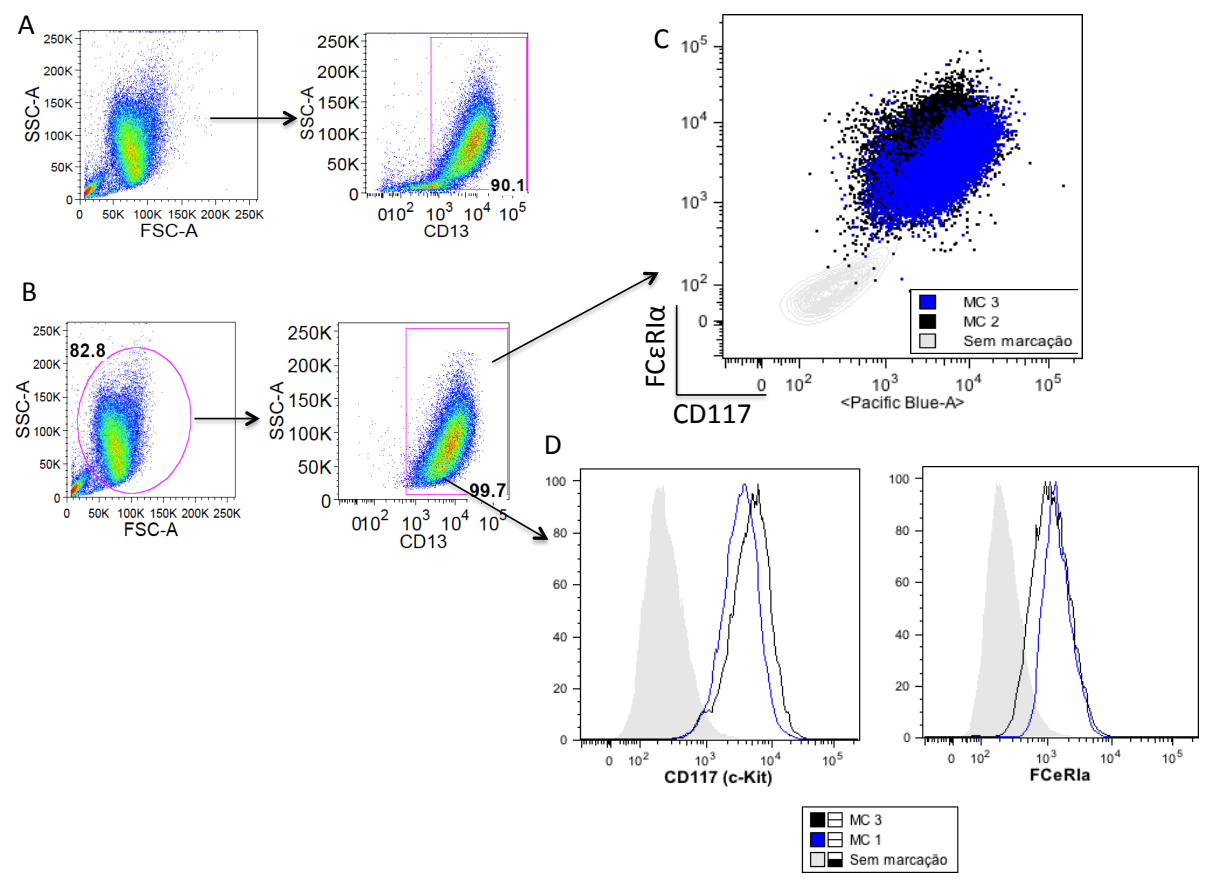

Figura 6. Representação da estratégia de gate empregada para fenotipagem e análise das populações de MCs derivadas da diferenciação in vitro a partir de células $\mathbf{C D}^{+} 4^{+}$. Células $\mathrm{CD} 34^{+}$foram isoladas por separação imunomagnética positiva e cultivadas por 56 dias, respeitando as 5 condições de cultivo descritas em 3.1.2., após 8 semanas, uma alíquota de $10^{5}$ células foi analisada por citometria de fluxo (A). Na análise de todos os eventos presentes na cultura, observamos que $90 \%$ das células eram comprometidas com o compartimento mieloide. (B) Selecionada a população de interesse, para tal, respeitamos os padrões de tamanho e granulosidade. Após, analisamos a expressão de CD13 presente na membrana das células, assim, pudemos perceber que mais de $99 \%$ das células estavam comprometidas com a diferenciação mieloide. Após, verificamos a expressão das moléculas FCERI $\alpha$ e CD117/c-Kit (C) Dot-plots, e (D) histogramas referentes a dois doadores diferentes (preto e azul). 


\subsubsection{Avaliação morfologia e fenotípica das linhagens de mastocitoma HMC-1.1 e HMC-1.2}

A diferenciação de mastócitos, mesmo bem-sucedida como descrito acima, é uma técnica que exige, no mínimo, 50 dias para obtenção de uma cultura enriquecida, sendo assim, desde seu isolamento em 1988, são utilizadas, na literatura, linhagens de leucemia mastocística (mastocitoma) como maneira alternativa à diferenciação, com o intuito de dinamizar o estudo da biologia de MCs. Essas linhagens crescem na ausência da adição de SCF (fator de crescimento de células tronco) e possuem uma única translocação cromossômica (10:16) (q2?2;q13q22), em cultura, estas células não são aderentes e formam pequenos agregados celulares (Butterfield, Weiler, Dewald, Gleich, 1988).

Nossa primeira observação quanto à comparação de $\mathrm{MCs}$ diferenciados com a linhagem HMC-1.1 e HMC-1.2 foi que ambas possuem características morfológicas semelhantes (Figura 7). Além disso, fez se necessária a avaliação das moléculas de superfície das linhagens e das células derivadas de células CD34 ${ }^{+}$.

Como demonstrado na Figura 7B, não observamos diferença quanto à importante molécula de diferenciação CD117. No entanto, notamos que a linhagem HMC-1.2 possui um perfil de MCs mais imaturo do que o diferenciado a partir de células $\mathrm{CD}^{+} 4^{+}$e da linhagem HMC-1.1, evidenciado pela alta expressão de c-Kit e baixa expressão do receptor de alta afinidade de $\operatorname{IgE}(\mathrm{FC} \varepsilon \mathrm{RI} \alpha)(10,09 \pm 3,01 \%)$ contra 46,14 $\pm 6,32 \%$ em HMC-1.1 e 57,58 \pm 5,78\% MCs, além de baixa expressão de CD33 (Siglec-3, detectado em mastócitos teciduais), sendo 28,30 \pm 4,60\% em HMC-1.2 contra 81,94 \pm 9,34\% (HMC-1.1) e 95,85 $\pm 1,42 \%$ (MCs), ainda notamos que as células HMC-1.1 parecem ser mais maturas que HMC-1.2, uma vez que expressam níveis maiores de FCeRI $\alpha$. Portanto, estas linhagens, em especial HMC-1.1, foram exploradas adiante em alguns experimentos pontuais. 


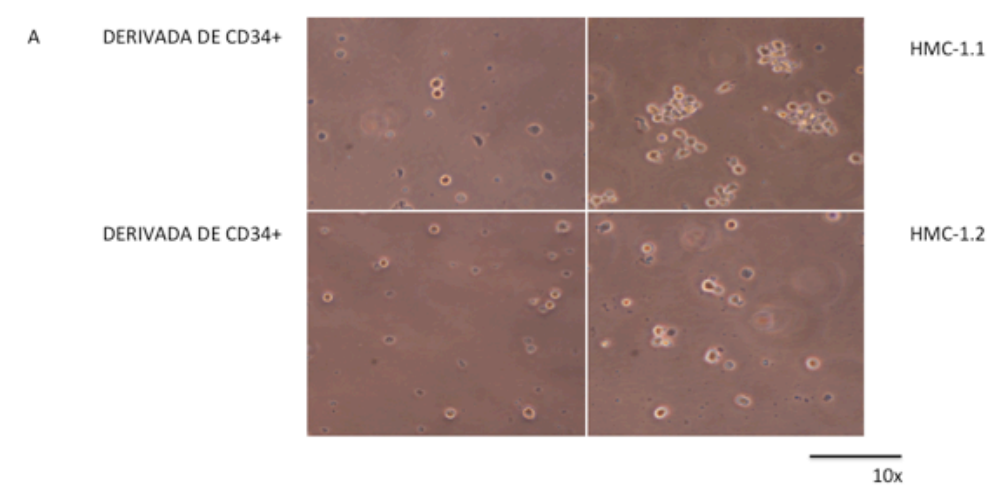

\section{B}
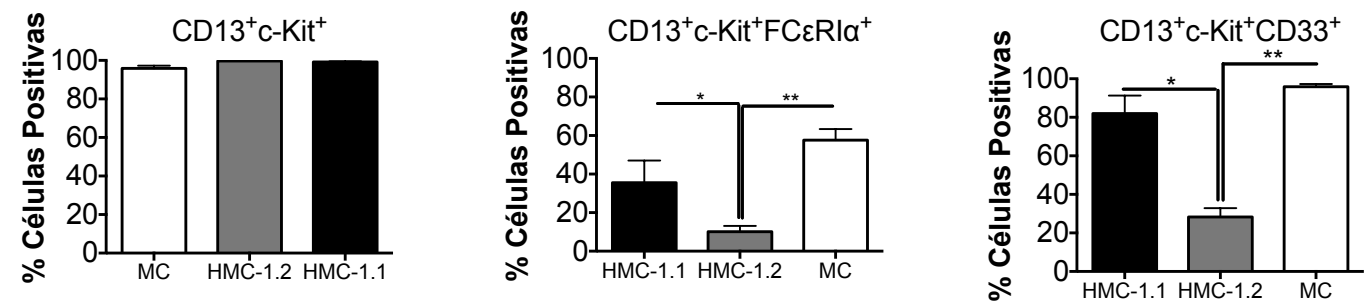

Figura 7. Comparação morfologia e imunofenotípica de MCs diferenciados in vitro a partir de células CD34+ (MCs) com linhagens de mastocitoma HMC-1.1 e HMC-1.2. (A) Fotos demonstrativas de culturas derivadas in vitro e linhagens de mastocitoma em que podemos observar semelhança morfologia entre as células. (B) Comparação da frequência de expressão das moléculas de membrana das células, quanto à análise estatística, foi utilizada a ANOVA seguida pelo teste de Tukey, sendo que $\mathrm{p}<0,05$ (*), p<0,01 (**) e p<0,001 (***); (MCs n=15, HMC.1-1 n=5 e HMC-1.2 n=5,). Foram adquiridos, no mínimo, 50.000 eventos dentro do gate de CD13 ${ }^{+}$

\subsection{Sorting de HCT-116 e mastócitos diferenciados}

Primeiramente, com o intuito de separar os MCs provenientes da co-cultura com a linhagem tumoral HCT-116, analisamos a expressão de CD66 e/a/c (EPICAM-1), marcador expresso pelas células tumorais, mas não por MCs. No entanto, contrariando nossas expectativas, a molécula CD66 e/a/c não era expressa em 100\% das células tumorais (Figura 8), assim, impossibilitando o uso deste anticorpo para a separação por FACS.

Assim, como alternativa, células da linhagem de câncer colorretal humano, HCT-116, foram coradas com CFSE ( $5 \mathrm{mM}$ ) e plaqueadas em garrafas de $25 \mathrm{~cm}^{3}$, após 4 horas, tempo necessário para a adesão celular, as células foram co-cultivadas com MC, sendo a proporção respeitada de 10 HCT-116 : 1 MC. Depois de 24 horas de cultura, as células não aderentes foram retiradas e centrifugadas. Após centrifugação, as células foram ressuspendidas em IMDM contendo $2 \%$ de SFB e filtradas em filtro de $70 \mu \mathrm{m}$ para evitar agregados celulares. 

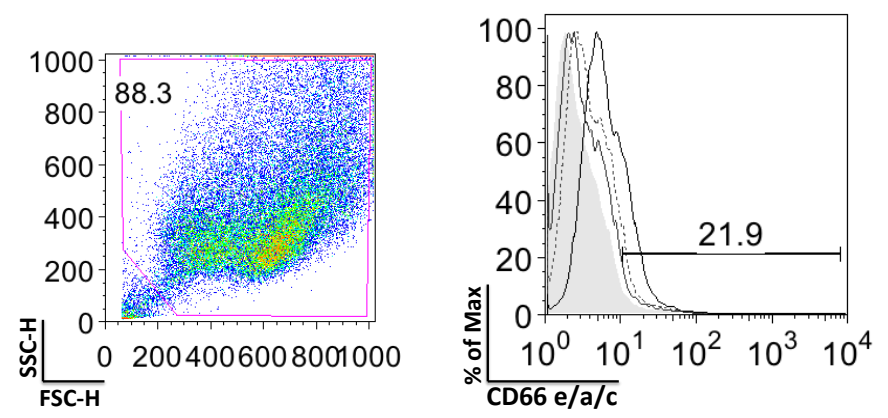

Figura 8. Análise da expressão da molécula CD66 e/a/c (EPICAM 1) pelas células HCT-116. Células HCT116 foram coradas com diferentes concentrações de anti-CD66 e/a/c, sendo a linha tracejada equivalente a $2 \mu \mathrm{L}$, linha cinza $4 \mu \mathrm{L}$ e linha preta $8 \mu \mathrm{L}$.

A suspensão celular foi separada por Facs-Aria, como estratégia de gate, foram eliminados os doublets e separadas as células CFSE (FITC) positivas das negativas (Figura 9A), assim, pudemos separar os mastócitos (não marcados) e HCT-116 (CFSE ${ }^{+}$) que perderam a adesão. Como controle de experimento, o tubo de células marcadas e não marcadas foram reanalisadas, assim, confirmamos a pureza de $95 \pm 5,0 \%$ de células não marcadas (Figura 9B).
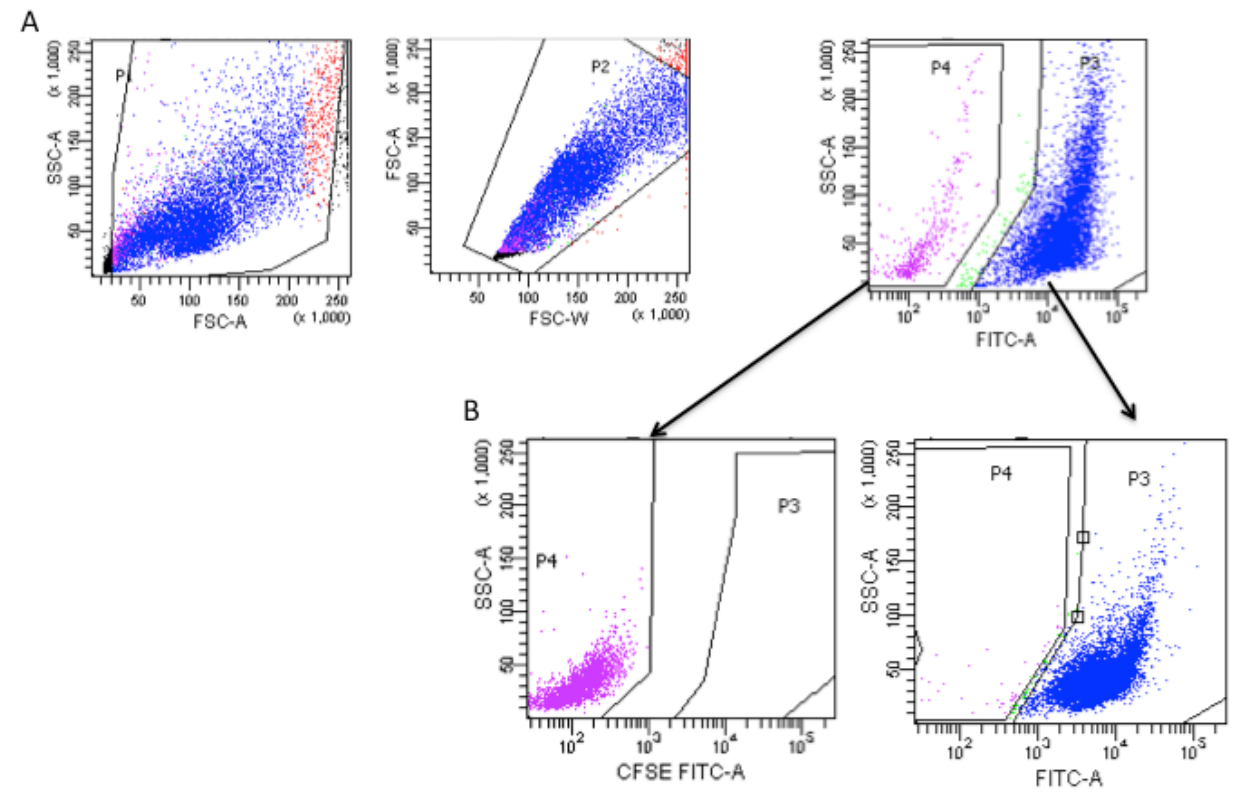

CFSE

Figura 9. Estratégia de gate utilizada no sorting de Mastócitos e HCT-116. Células HCT-116 pré-coradas com CFSE (FITC) foram co-cultivadas com não corados por 24 horas, após período de cultura, as células não aderentes foram removidas e analisadas em citômetro FACS-ARIA. Em (A), demonstramos as populações presentes na suspensão de células, sendo azul as células FITC positiva, em geral, HCT-116, e, em roxo, as células não marcadas, em geral, MCs. Quanto à estratégia de análise, primeiramente, selecionamos os gate referentes às células (P1), após, excluímos as células duplas pela análise de FSC-W versus FSC-A (P2). Por fim, 
foram definidas duas populações distintas, P3 e P4. Estas populações celulares foram, então, separadas. Em (B), exibimos o produto da separação (pós-sorting) da fração de células não marcadas e marcadas.

Com o intuito de averiguar se o nozzle escolhido - $85 \mu \mathrm{m}$ - não causava diminuição da viabilidade das células após o sorting, as células fluorescentes em FITC, em geral, HCT-116, foram plaqueadas na concentração de $2 \times 10^{4}$ células $/ 100 \mu \mathrm{L}$ em placas de 96 poços, após 4 horas, as células foram marcadas com $100 \mu \mathrm{L}$ de MTT $(1 \mathrm{mg} / \mathrm{mL})$, permaneceram nesta condições por 2 horas, assim, pudemos inferir que, mesmo após a separação das células, estas continuavam viáveis (Figura 10). O mesmo não foi realizado para os MCs (células não marcadas), uma vez que não obtivemos células suficientes para tal ensaio, no entanto, considerando que as células tumorais são, em média, maiores do que os MCs, torna-se possível assumir que a pressão exercida pelo nozzle também não foi capaz de alterar a viabilidade celular de MCs.

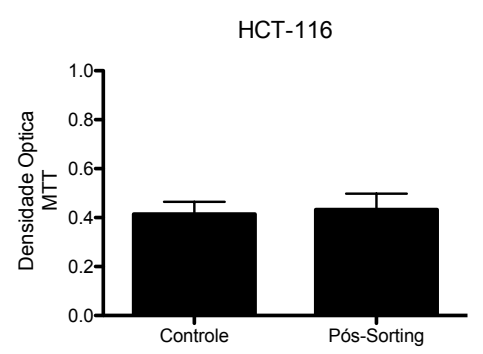

Figura 10. Avaliação da pressão exercida pelo nozzle quanto à viabilidade de células HCT-116, após o sorting. Com o intuito de averiguar se o nozzle escolhido - $85 \mu \mathrm{m}$ - não causava diminuição da viabilidade das células após o sorting, as células fluorescentes em FITC, em geral, HCT-116, foram plaqueadas na concentração de $2 \times 10^{4}$ células $/ 100 \mu \mathrm{L}$ em placas de 96 poços, após 4 horas, as células foram marcadas com $100 \mu \mathrm{L}$ de MTT $(1 \mathrm{mg} / \mathrm{mL})$, permaneceram nestas condições por 2 horas, o gráfico representa a viabilidade celular expressa em densidade óptica das células HCT-116, em controle, são HCT-116 que não foram sortidas.

4.3 Avaliação da presença de mastócitos após o sorting e da interação destas com células dendríticas autólogas.

Com o intuito de confirmar a separação de MCs pós-sorting, bem como, a interação destas com DCs autólogas, as células não marcadas, separadas acima, foram, então, marcadas com o receptor de alta afinidade para IgE (FITC) e co-cultivadas com iDC autólogas, previamente coradas com corante vermelho (PE), após 5 minutos de co-cultura, tanto a marcação quanto a interação celular foram analisadas por microscopia confocal (Zeiss LSM780 NLO) (Figura 11A). Inicialmente, observamos que a separação celular por FACS foi capaz de manter a viabilidade e pureza dos MCs, uma vez que estes expressavam FCeRI $\alpha$ e se 
movimentavam pela placa de petri, notamos, ainda, que MCs e DCs pareciam interagir, com tempo médio 1'17', (Figura 11B).
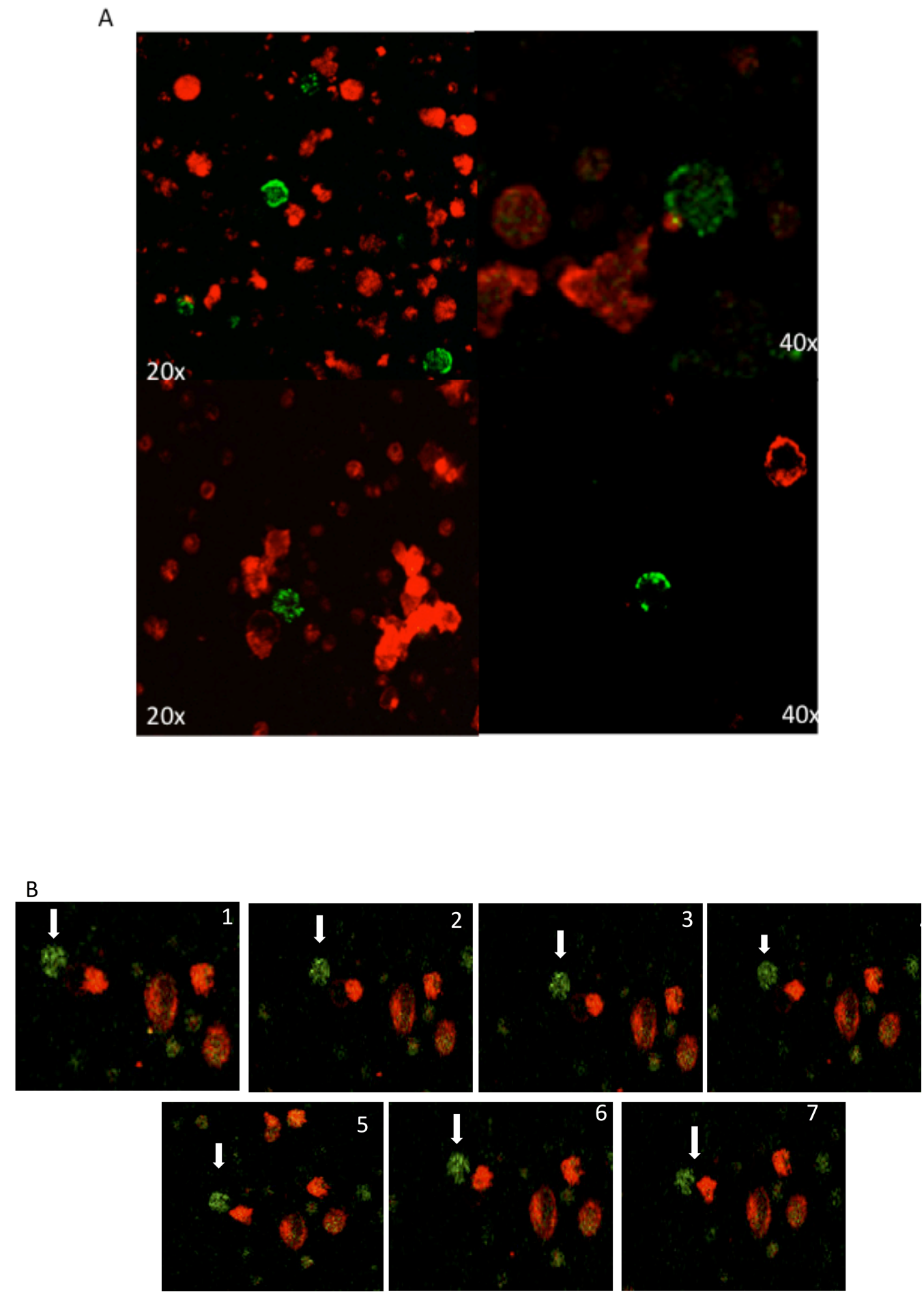

CORANTE LARANJA (CULTURA não enriquecida de DC) FCeRla (Mastócito)

Figura 11. Avaliação da presença de MCs após o sorting e da interação destas com DCs autólogas. Em (A) as células que não eram positivas para CFSE foram marcadas com anticorpo FCeRIa, como mostrado na figura, as células separadas que não eram fluorescentes expressavam FCeRI $\alpha$, demonstrando que nossa separação 
ocorreu com sucesso. (B) Representação da interação de DCs autólogas (em vermelho) e MC (verde) durante 1 hora de filmagem.

\subsection{Avaliação do fenótipo após co-cultura em monolayer.}

Nesta etapa do estudo, avaliamos a dinâmica da expressão das moléculas de superfície durante a maturação de DCs co-cultivadas em monolayer com MCs autólogos (iDC-MC) ou MCTs autólogos (iDC-MCT). Para tal, PBMC autólogas aos MCs foram descongeladas; e seguido o protocolo de diferenciação in vitro descrito no item 3.5. Após 5 dias de cultura, pudemos observar que grande parte da cultura apresentava morfologia semelhante a DCs (Figura 12B), no quinto dia de diferenciação, foram removidas da placa e, então, replaquedas e co-cultivadas com MCs autólogos (iDC-MC) ou sensibilizados com HCT-116 (iDC-MCT), sendo respeitada a proporção de 5 DCs: 1MC, após dois dias de cultura, notamos DCs e MCs que pareciam interagir (Figura 12C).

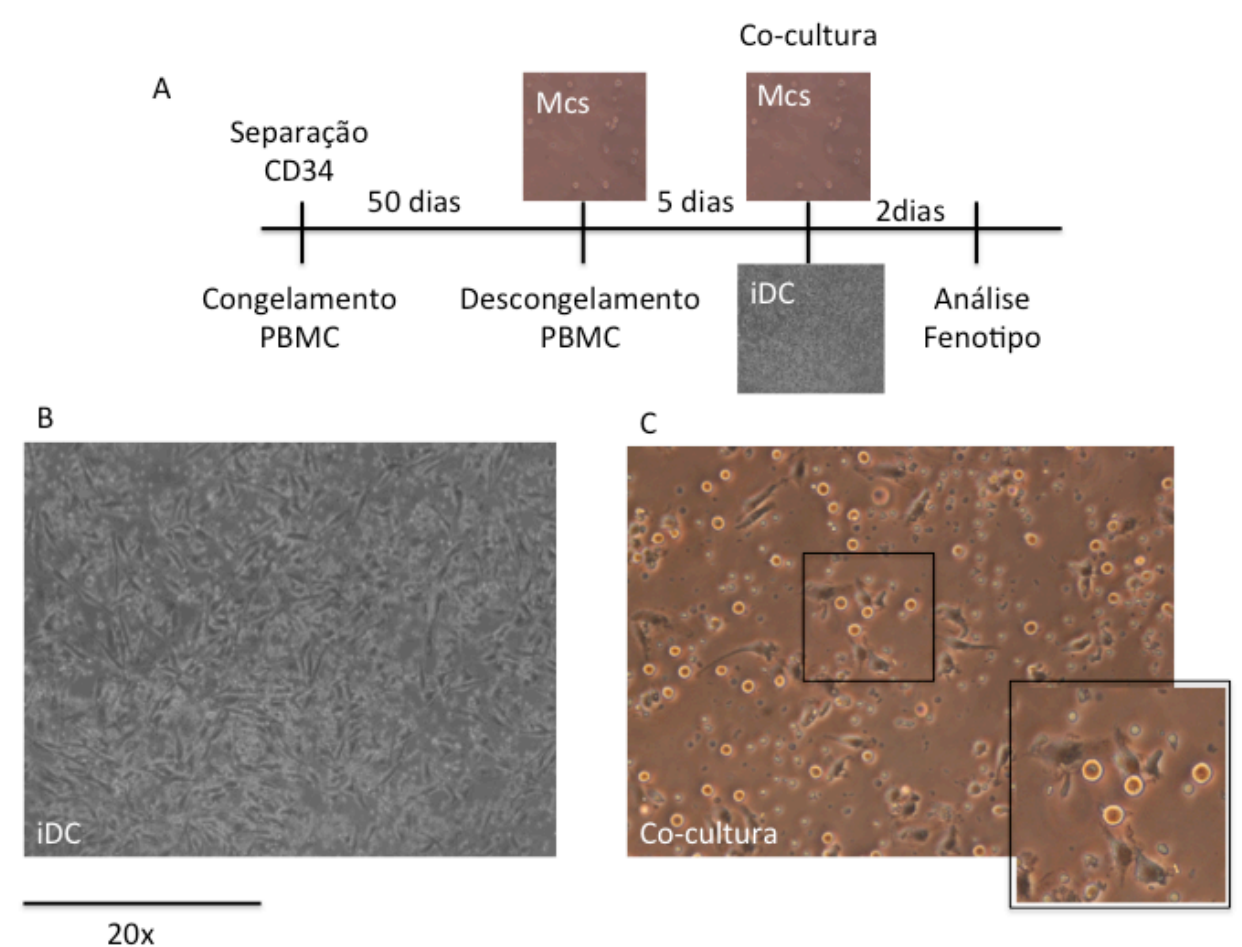

Figura 12. Avaliação do fenótipo após co-cultura em monolayer. (A) Esquema representativo do delineamento experimental. Em (B), demonstramos a morfologia das iDCs presentes no 5 dia de cultura e (C) representação fotográfica da co-cultura em monolayer de iDC com MCs (MCs) após dois dias de cultivo. No detalhe, sugerimos uma possível interação entre as células.

Depois de dois dias de co-cultivo, as células foram removidas da placa para análise dos marcadores de superfície, para tal, foram adquiridos 50.000 eventos presentes na co- 
cultura dos diferentes grupos, após, foram selecionados apenas os eventos único (singlets), seguidos pela análise dos parâmetros de tamanho e granulosidade, por fim, selecionamos as células pela expressão de CD11c (marcador expresso por DC, mas não por MC) (Figura 13), dentro desta população, analisamos a expressão dos outros marcadores de interesse.

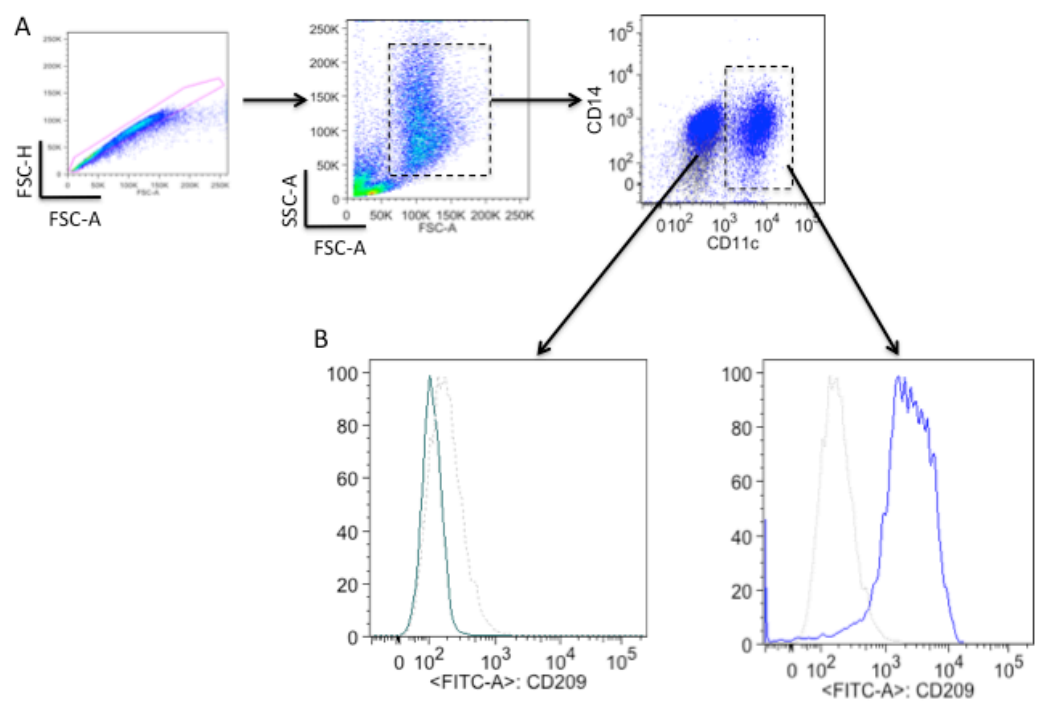

Figura 13. Representação da estratégia empregada para a análise dos marcadores em DC. Após dois dias de co-cultivo (DCs e MCs), as células foram removidas da placa, e o seu fenótipo analisado por citometria de fluxo. Para tal, foram adquiridas, no mínimo, 50.000 eventos totais (A), quanto à estratégia de análise, primeiramente, excluímos as células duplas pelos parâmetros de FSC-A vs FSC-H, seguido pela escolha da população pelos parâmetros de tamanho e granulosidade, após, pela análise da expressão de CD11c e não de CD14. Sendo a população representada por CD11 $\mathrm{c}^{\text {neg }}$ (principalmente MCs) e CD11 ${ }^{+}$(iDCs) (B). Com o intuito avaliar a confiabilidade da escolha dos gates, analisamos a expressão de CD209 nas populações CD11 $\mathrm{c}^{\text {neg }} \mathrm{e}$ CD11 $\mathrm{c}^{+}$, conforme esperado, apenas as células positivas para CD11c expressavam, também, CD209, assim, validando a escolha dos gates.

O estudo dos marcadores fenotípicos demonstrou uma similaridade da frequência de $\mathrm{HLA}^{-D R^{+}}$e CD209 ${ }^{+}$dentro da população CD11c ${ }^{+}$, mas CD209 (DC-SIGN) não foi expresso

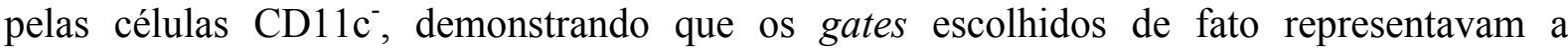
população DCs (Figura 13B).

Em nossos resultados, observamos que, quando compradas com iDCs, iDC-MC expressam menos CD83 (marcador de ativação) e CD1a (DC derivadas de monócito in vitro), quanto ao grupo iDC-MCT, a diminuição da frequência CD1a foi mantida, mas não a diminuição da expressão de CD83. Vale notar que o grupo iDC-MCT demonstrou maior frequência de células $\mathrm{CD} 11 \mathrm{c}^{+} \mathrm{PD}-\mathrm{L}^{+}{ }^{+}$e $\mathrm{CCR} 7^{+}$. Ainda, o aumento da frequência de células $\mathrm{CCR}^{+}$, além de diferente do expresso por iDC, foi também significativamente maior se comparado ao grupo iDC-MC. Embora não significativo, notamos, também, menor frequência 
de células CD11c positivas para CD86 (co-estimuladora), CD80 (co-estimuladora) e CD40 (co-estimuladora) nos grupos iDC-MC e iDC-MCT (Tabela 1).

Tabela 1. Frequência das moléculas de superfície nos diferentes grupos de co-cultivo em monolayer. Para a análise de significância estatística, foi utilizada a análise de variância one-way ANOVA seguida por Tukey, sendo $\mathrm{p}<0,05(* / \#)$, quando diferente de iDC $(*)$ e (\#) de iDC-MC.

\begin{tabular}{|c|c|c|c|}
\hline Células & iDC & iDC-MC & iDC-MCT \\
\hline HLA-DR & $97,19 \pm 3,95$ & $94,91 \pm 5,09$ & $93,72 \pm 6,64$ \\
\hline CD1a & $45,27 \pm 17,68$ & $12,43 \pm 6,94\left({ }^{*}\right)$ & $15,48 \pm 7,65\left(^{*}\right)$ \\
\hline CD209 & $89,36 \pm 8,18$ & $76,78 \pm 8,82$ & $84,10 \pm 14,98$ \\
\hline CD83 & $29,77 \pm 15,35$ & $6,640 \pm 3,58(*)$ & $23,93 \pm 8,89$ \\
\hline CD80 & $49,90 \pm 16,13$ & $32,68 \pm 10,19$ & $42,82 \pm 12,86$ \\
\hline CD86 & $79,65 \pm 18,45$ & $71,41 \pm 15,69$ & $77,76 \pm 13,56$ \\
\hline CD40 & $91,20 \pm 5,95$ & $89,90 \pm 4,79$ & $88,67 \pm 7,29$ \\
\hline CCR7 & $68,48 \pm 8,75$ & $58,70 \pm 7,59$ & $84,10 \pm 5,14$ (*/\#\#) \\
\hline PD-L1 & $70,95 \pm 14.07$ & $73,61 \pm 2,44$ & $89,24 \pm 6,56\left(^{*}\right)$ \\
\hline
\end{tabular}

Em relação à MFI (intensidade mediana de fluorescência), para as mesmas moléculas avaliadas, optamos em normatizar os valores usados como referência os valores de MFI obtidos do grupo-controle iDC (valores originais estão representados na Tabela 2). Nesta padronização, notamos que a co-cultura (iDC-MC) não alterou a intensidade de CD1a, garantindo que o co-cultivo não foi capaz de alterar o comprometimento das DCs derivadas de monócitos, no entanto, observamos uma diminuição significativa da expressão de HLADR (molécula principal de histocompatibilidade classe II) e CD80 (co-estímulo), associado a uma tendência à diminuição da intensidade de CD40 (co-estímulo) e CD209 (Lectina do tipoC). Paralelamente, notamos aumento da expressão de CD274/PDL1 (co-inibitória) (Figura 14) e uma tendência de aumento da expressão da molécula CCR7 (quimiorreceptor, relacionada à migração aos linfonodos). 
Tabela 2. MFI das moléculas de superfície nos diferentes grupos de co-cultivo em monolayer. Para a análise de significância estatística, foi utilizada a análise de variância one-way ANOVA seguida por Tukey, sendo $\mathrm{p}<0,05(*)$, quando diferente de iDC $(*)$.

\begin{tabular}{|c|c|c|c|}
\multicolumn{4}{c}{ iDC } \\
Moléculas & iDC-MC & iDC-MCT \\
\hline HLA-DR & $33690 \pm 13171$ & $7093 \pm 910\left(^{*}\right)$ & $8145 \pm 2680\left(^{*}\right)$ \\
\hline CD1a & $757 \pm 341$ & $615,2 \pm 132,4$ & $710 \pm 287$ \\
\hline CD209 & $1873 \pm 976,2$ & $1263 \pm 417,8$ & $1028 \pm 446,7$ \\
\hline CD83 & $299,6 \pm 114,5$ & $387,3 \pm 178,9$ & $236,7 \pm 146,3$ \\
\hline CD80 & $473,6 \pm 149,9$ & $336,5 \pm 94,32$ & $247 \pm 38,17\left(^{*}\right)$ \\
\hline CD86 & $888,7 \pm 384,2$ & $714,3 \pm 210,4$ & $1250 \pm 1281$ \\
\hline CD40 & $1823 \pm 803,3$ & $1216 \pm 386,6$ & $880,5 \pm 138,1$ \\
\hline CCR7 & $548,1 \pm 218,2$ & $678,9 \pm 98$ & $612,3 \pm 2086$ \\
\hline PD-L1 & $473,7 \pm 95,79$ & $622,8 \pm 103,8$ & $405,7 \pm 145,5$ \\
\hline
\end{tabular}

Quanto ao grupo de iDC-MCT, a intensidade de CDla também se manteve, bem como, a diminuição significativa da molécula HLA-DR. No entanto, notamos que a diminuição da intensidade referente às moléculas CD80, CD209 e CD40 se intensificaram, e, embora não significativo, observamos uma diminuição relativa da intensidade do CD83 (marcador de ativação de DCs). Quanto ao aumento da molécula PD-L1, este não foi observado em iDC-MCT, no entanto, vale destacar que houve um aumento na frequência de células positivas para este marcador no grupo em questão (Tabela 1). Curiosamente, tanto em iDC-MC quanto em iDC-MCT não observamos nenhuma variação da intensidade da molécula CD86 (co-estímulo).

Portanto, considerando o imunofenótipo observado, sugerimos que tanto com iDC-MC quanto iDC-MCT parecem respeitar um perfil de DCs tolerogênicas (tDCs). 

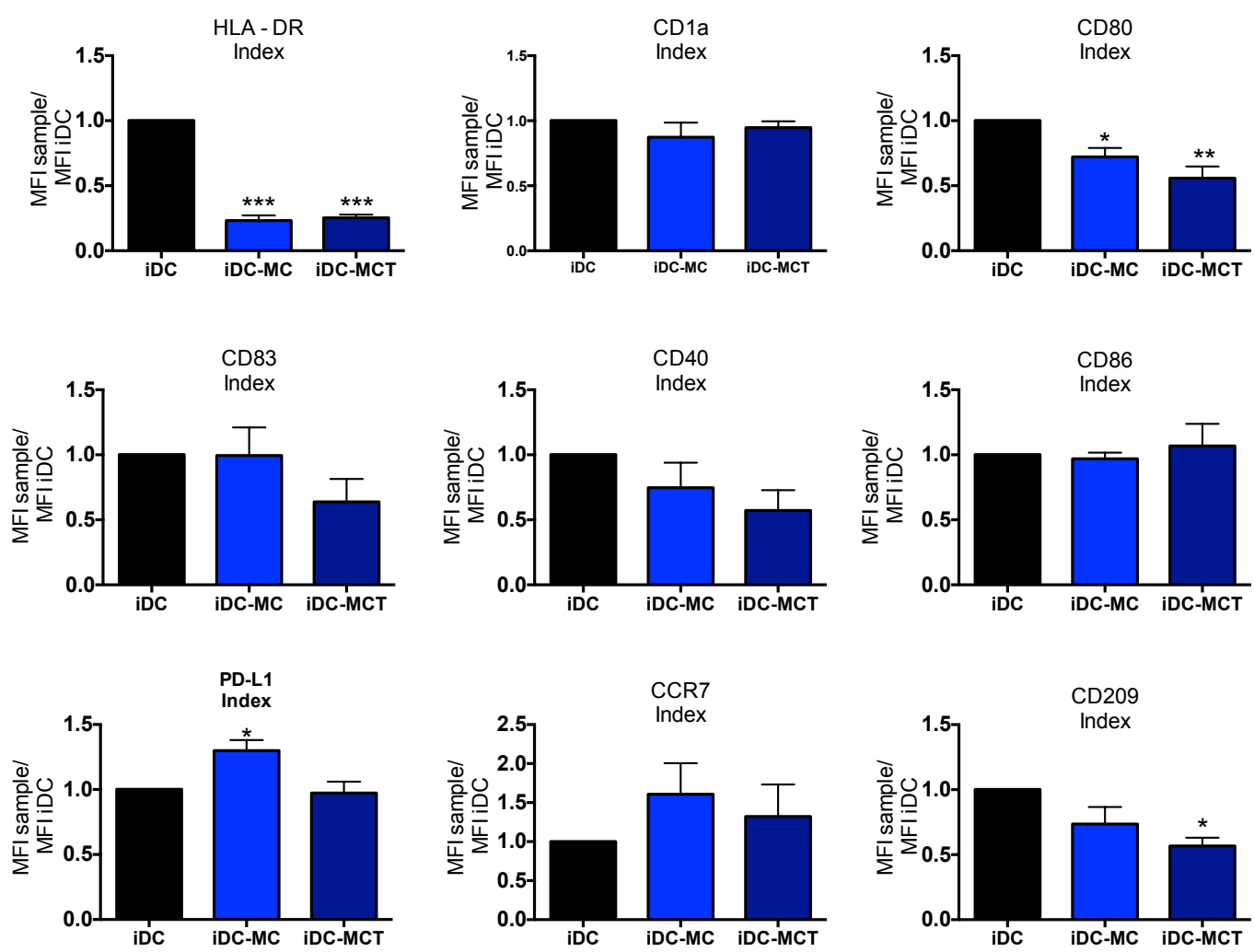

Figura 14. Gráficos do índex intensidade Mediana de Fluorescência (MFI) das células positivas quanto às moléculas de superfície em células dendríticas imaturas (controle), co-cultivadas com mastócito em monolayer (iDC-MC) ou co-cultiva com mastócitos sensibilizados com a linhagem tumoral HCT-116 em monolayer (iDC-MCT). (A) No quinto dia de cultura, as iDCs foram retiradas das placas, e replaquedas com MCs (iDC-MC), MCTs (iDC-MCT) ou mantidas em cultura (iDC). Após dois dias de cultivo, as células foram fenotipadas e analisadas comparativamente quanto ao índice da intensidade mediana de fluorescência, sendo este o resultado da razão da MFI obtido no grupo experimental pelo valor de iDC (controle); iDC, n=5; iDC-MC $\mathrm{n}=5$; iDC-MCT; $\mathrm{n}=5$, para análise estatística, foi utilizado o teste de one-way ANOVA, seguido pelo pós-teste de Tukey, sendo $\mathrm{p}<0,05(*), \mathrm{p}<0,01(* *)$ e $\mathrm{p}<0,001(* * *)$.

Embora tenhamos analisados os marcadores dentro de células $\mathrm{CD} 11 \mathrm{c}^{+}$, molécula não expressa em MCs, com o intuito de validar a modulação das moléculas de co-estímulo e, principalmente, os resultados da proliferação (adiante), analisamos a presença de CD80, CD86 e CD40 em células CD11 (vermelho) e CD11 ${ }^{+}$(azul). Conforme exibido na Figura 15, somente as células positivas para CD11c (DCs) (azul), expressavam as moléculas de coestímulo, demonstrando que os fenômenos encontrados correspondiam, de fato, apenas às DCs. 

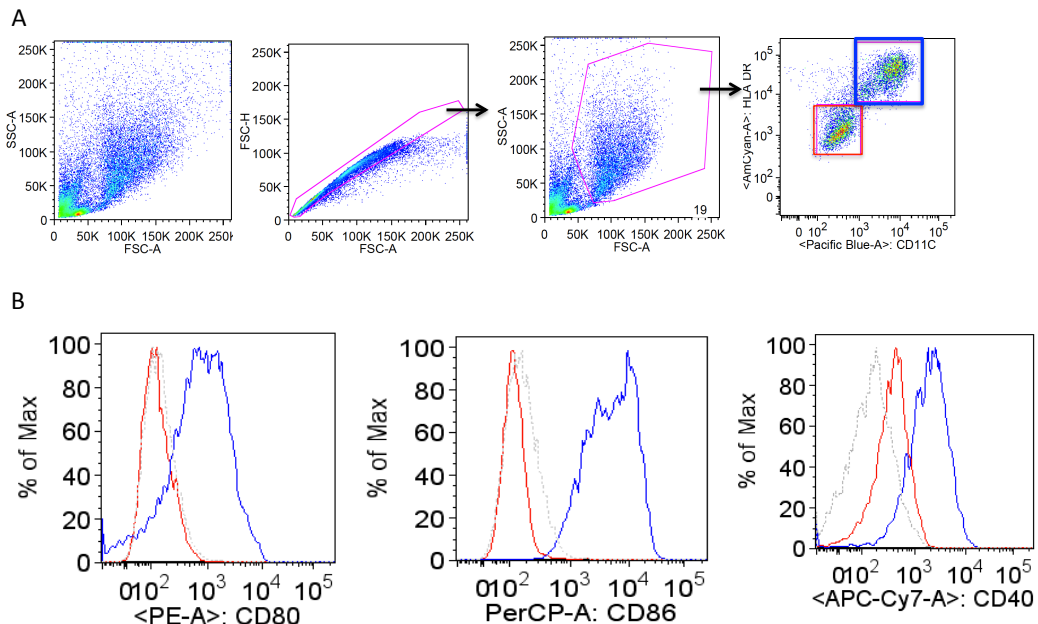

Figura 15. Avaliação da expressão de moléculas de co-estímulo nas células DCs e MCs. Após dois dias de co-cultivo (DCs e MCs), as células foram removidas da placa, e o seu fenótipo analisado por citometria de fluxo. Para tal, foram adquiridos, no mínimo, 50.000 eventos totais (A), quanto à estratégia de análise, primeiramente, excluímos as células duplas pelos parâmetros de FSC-A versus FSC-H, seguido pela escolha da população de interesse baseado em tamanho e granulosidade, após análise da expressão de CD11c e HLA-DR, sendo esta

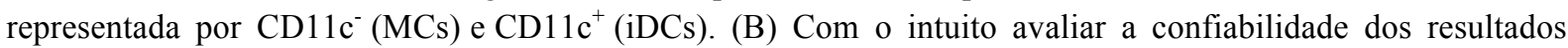
relativos à expressão das moléculas de co-estímulo, avaliamos a intensidade de fluorescência de CD80, CD86 e CD40 nas populações CD11 HLA-DR ${ }^{+}$(vermelho) e CD11 $\mathrm{c}^{+} \mathrm{HLA}_{\mathrm{L}} \mathrm{DR}^{+}$(azul), demonstrando, assim, que as moléculas de co-estímulo eram somente expressas nas DCs $\left(\mathrm{CD} 11 \mathrm{c}^{+} \mathrm{HLA}_{-} \mathrm{DR}^{+}\right)$.

4.5 Análise da produção de citocinas por células dendríticas co-cultivas com mastócitos.

Os sobrenadantes obtidos da co-cultura de iDC com MCs ou MCT foram submetidos à avaliação quanto à presença de citocinas inflamatórias por ensaio baseado na captura de beads (CBA). Primeiramente, avaliamos a presença das citocinas IL-8, IL-6 e IL-10 presentes nas co-culturas de iDC-MC ou iDC-MCT. Quanto à produção de IL-8, não notamos nenhuma diferença, observamos, no entanto, menor produção de IL-6 no sobrenadante do co-cultivo de iDCs tanto com MC quanto MCT (iDC=1941 $\pm 878,8$; iDC-MC = 133,9 $\pm 108,4$; iDC-MCT $=75,95 \pm 57,08 ; \mathrm{ng} / \mathrm{mL}$ ), sugerindo que o co-cultivo poderia resultar na diminuição da inflamação. Em contrapartida, não observamos maior produção de IL-10 (Figura 16). 
IL-8 IL-6

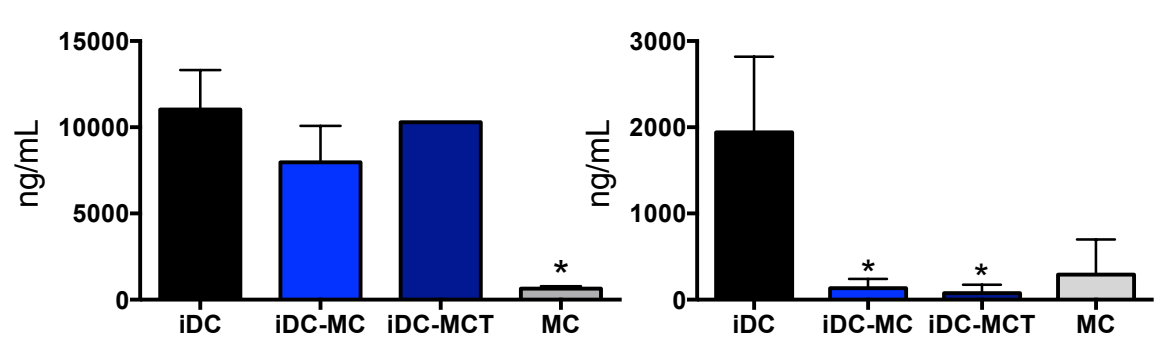

IL-10

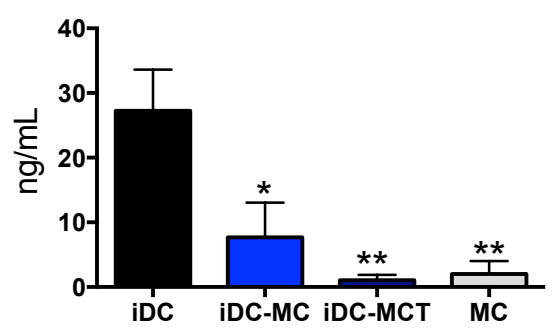

Figura 16. Avaliação das citocinas peresentes no sobrenadante após dois dias de co-cultivo. O sobrenadante após dois dias de co-cultivo de Mastócitos ou mastócitos "sensibilizados" com a linhagem tumoral HCT-116 (iDC-MC ou iDC-MCT, respectivamente) foi removido da placa, centrifugado e submetido ao processo de marcação de citocinas inflamatórias baseado na captura de beads (CBA). Como controle, analisamos as citocinas presentes no sobrenadante de DCs imaturas (iDC) e mastócitos (MC) mantidas em cultura por 2 dias. iDC ( $\mathrm{n}=4$ ); iDC-MC ( $n=4)$; iDC-MCT ( $n=4)$, para análise estatística, foi utilizado o teste de one-way ANOVA, seguido pelo pós-teste de Tukey, sendo $\mathrm{p}<0,05(*), \mathrm{p}<0,01(* *)$ e $\mathrm{p}<0,001(* * *)$.

4.6 Avaliação da capacidade linfoestimuladora de células dendríticas co-cultivadas com mastócitos.

Com o intuito de avaliar a capacidade estimuladora de iDCs, iDC-MC e iDC-MCT, células mononucleares não aderentes (CNAs) de doadores saudáveis não relacionados foram submetidas à separação imunomagnética por beads para o isolamento de linfócitos $\mathrm{T}\left(\mathrm{CD}^{+}\right)$ (Figura 17). A avaliação da eficiência do isolamento foi realizada por citometria de fluxo, sendo a pureza igual ( $\pm 95 \%)$ (Figura 18$)$. Para os experimentos de proliferação alogênica, células $\mathrm{CD}^{+}$foram marcadas com CFSE e co-cultivadas com DCs oriundas dos diferentes tratamentos. Assim, as iDCs foram retiradas após sete dias de cultivo, sendo que, do quinto ao sétimo, as células foram co-cultivadas com MCs ou MCTs. As células foram, então, contabilizadas e utilizadas como estimuladoras de células $\mathrm{T}$ (marcadas com CFSE); foi respeitada a proporção de 1 iDC: 10 Linfócitos T. 


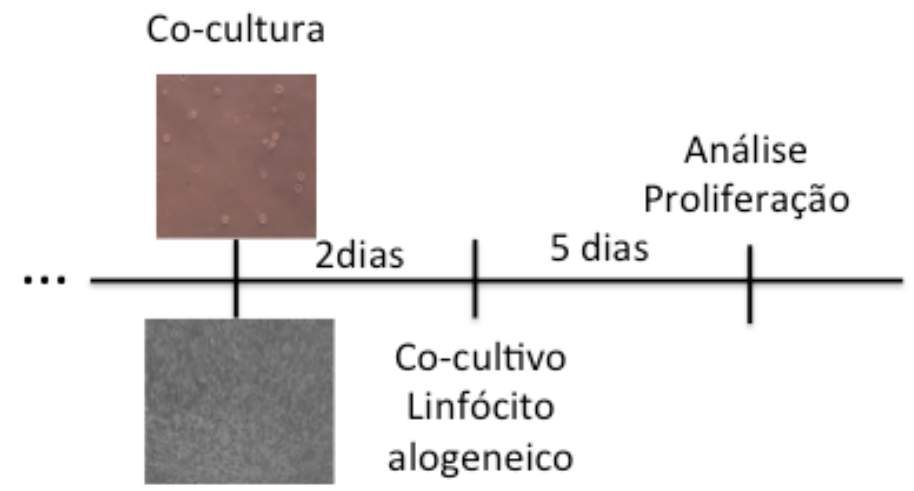

Figura 17. Representação gráfica do delineamento experimental. Após 2 dias de co-cultivo de DC com MCs (5:1), as células foram retiradas da placa, quantificadas e postas em co-cultura com linfócito $\mathrm{T}$ separado previamente por seleção imunomagnética (1:10). As células permaneceram em cultura por 5 dias. Transcorrido o tempo de cultivo, as células foram marcadas extracelularmente com anti-CD3, anti-CD4, anti-CD25 e anti-CD8.
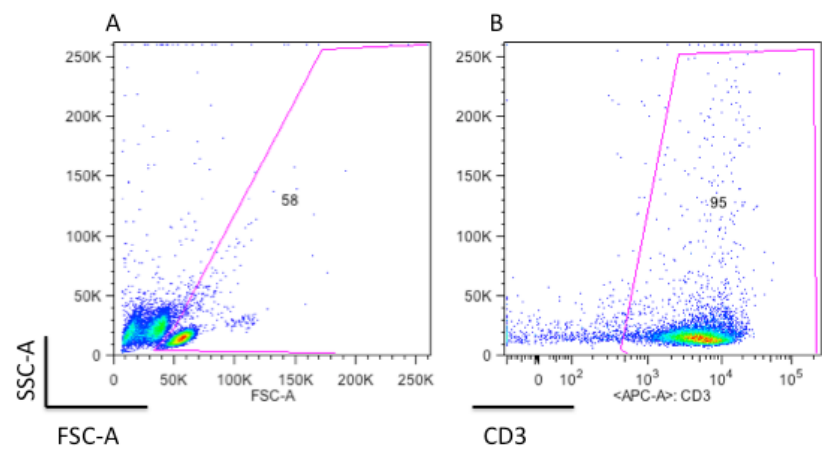

Figura 18. Gráficos representativos do isolamento de linfócitos por seleção imunomagnética. (A) Células presentes após processo de isolamento; (B) Análise da expressão de CD3 ( $\pm 95 \%$ ).

Corroborando com o fenótipo observado, as iDC-MC e iDC-MCT demonstraram menor capacidade de estimular a proliferação de linfócitos $\mathrm{CD}^{+}$, sendo que consideramos a diluição do corante como parâmetro de proliferação. Observamos que as iDC foram capazes de estimular $64,76 \pm 4,76 \%$ dos linfócitos T, enquanto iDC-MC estimularam apenas 42,58 \pm $5,84 \%$ e iDC-MCT $32,71 \pm 4,15 \%$ (Figura 19 ). 
A
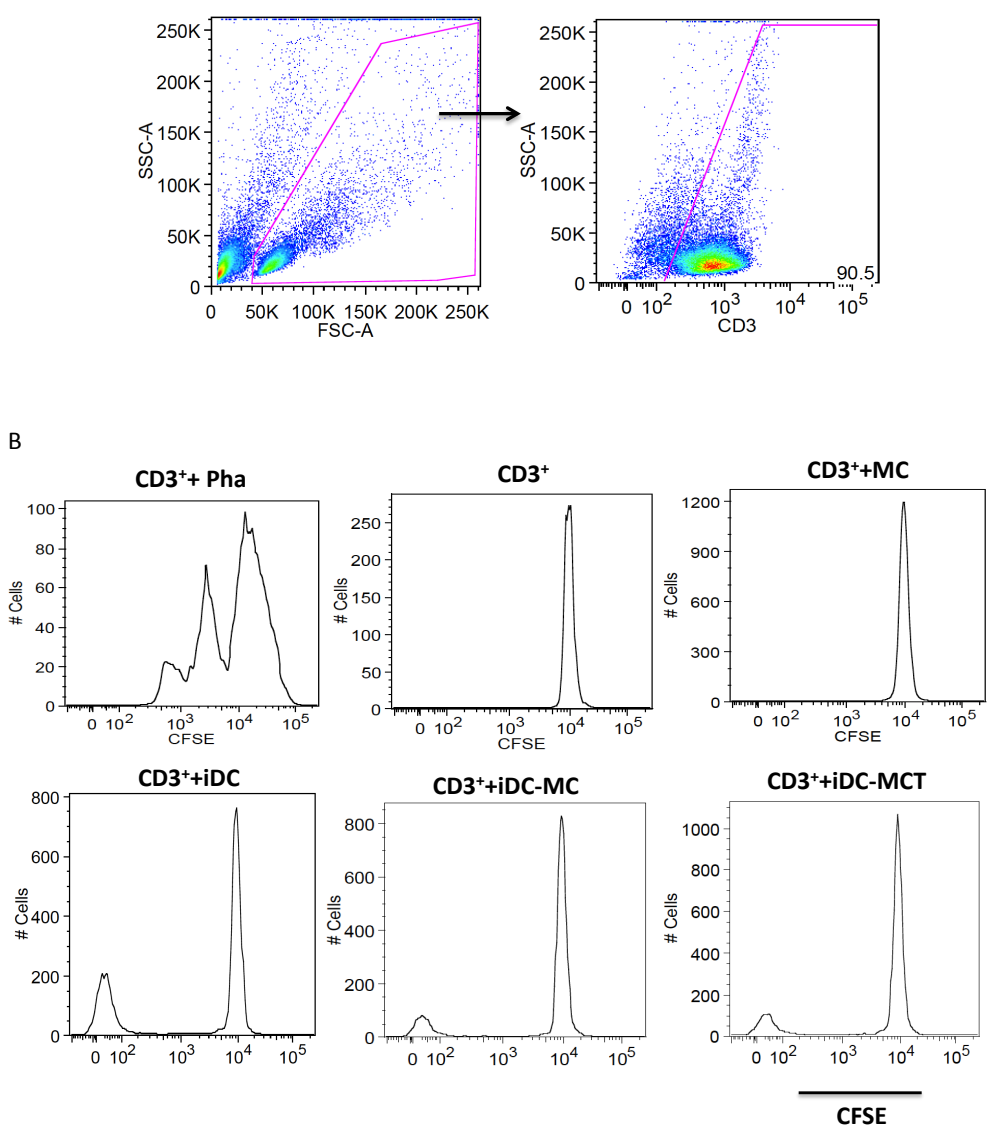

Figura 19. Capacidade estimuladora de células dendríticas imaturas co-cultivadas ou não com mastócitos. Representação em histograma da capacidade de proliferação, em que, na abscissa, está expresso o índice da fluorescência do CFSE. (A) demonstração da estratégia de análise, em que somente as células $\mathrm{CD}^{+}$foram escolhidas, nesta população, foi analisada a diluição do CFSE (B) esquerda para direita, grupo de estímulo positivo, sendo este feito com $1 \%$ volume/volume de fito-hemaglutinina-A (PHA), seguido pelo controle negativo (linfócitos cultivados apenas com meio de cultura), ao lado, linfócitos co-cultivados com MCs. Abaixo, estão exibidos os grupos experimentais.

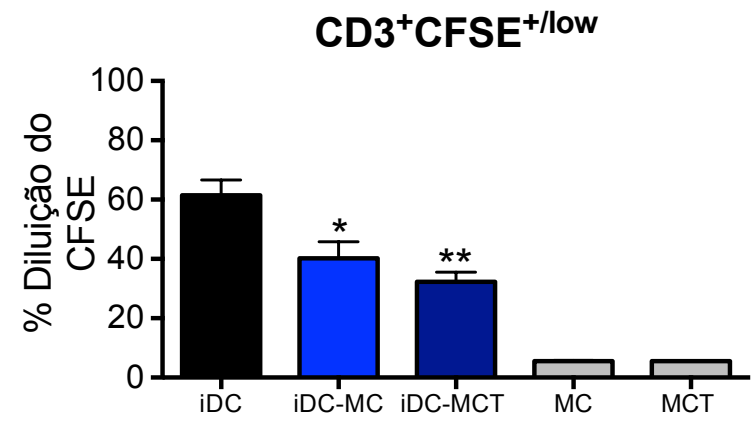

Figura 20. Representação gráfica do resultado da diluição do CFSE. Após cinco dias de co-cultura, as células foram removidas da placa e a diluição do corante $\mathrm{CFSE}$ das células $\mathrm{CD}^{+}$foi analisada por citometria de fluxo; PHA; n=8; SE; n=8; iDC; iDC-MC; n=8; iDC-MCT;n=5; n=8; MC n=3; MCT; n=3. Para análise estatística, foi utilizado o teste de ANOVA, seguido pelo pós-teste de Tukey, sendo $\mathrm{p}<0,05\left(^{*}\right), \mathrm{p}<0,01(* *)$ e $\mathrm{p}<0,001(* * *)$ 
Embora não tenhamos observado diferenças quanto à expressão de CD4 e CD8, bem como, alteração na relação destes subtipos (Figura 21) dentre as células que proliferaram, notamos que a molécula CD25 (cadeia $\alpha$ do recptor de IL-2), classicamente relacionada com a proliferação de linfócitos $\mathrm{T}$, mostrou-se mais expressa em linfócitos $\mathrm{T}$ co-cultivados com iDC-MCT. Isto, ao analisamos o índex de expressão desta molécula, definido como o produto da frequência pela MFI, e o grupo iDC-MC demonstrou uma tendência de aumento da mesma molécula (Figura 22). No entanto, em ambos os grupos, tal aumento não refletiu em maior proliferação de linfócitos (Figura 19 e 20).
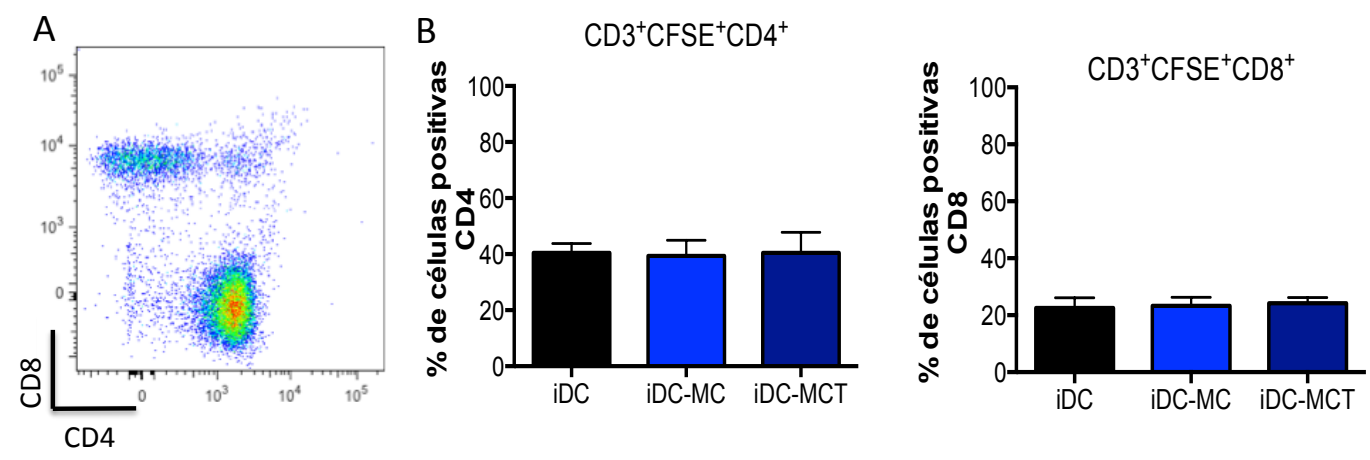

Figura 21. Representação gráfica da frequência de células $\mathrm{CD3}^{+} \mathrm{CFSE}^{+/ l o w} \mathrm{CD}^{+}$ou $\mathrm{CD3}^{+} \mathrm{CFSE}^{+/ l o w} \mathrm{CD8}^{+}$. (A) Dot-Plot demonstrativo da frequência de células $\mathrm{CD} 4$ e CD8, (B) frequência da população $\mathrm{CD} 4+$ que proliferou, ao lado, frequência da população CD8+ que proliferou (iDC; $n=8$; iDC-MC; $n=8$; iDC-MCT; $n=5$; para análise estatística, foi utilizado o teste de ANOVA, seguido pelo pós-teste de Tukey, sendo $\mathrm{p}<0,05(*)$, $\mathrm{p}<0,01(* *)$ e $\mathrm{p}<0,001(* * *)$.

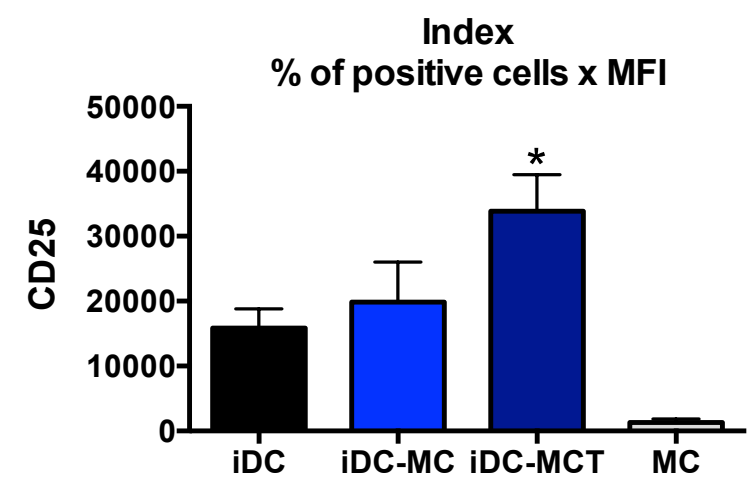

Figura 22. Representação gráfica da frequência e da intensidade mediana de fluorescência (MFI) das células $\mathbf{C D 3}^{+} \mathbf{C D 4}^{+} \mathbf{C D 2 5}^{+}$. (iDC; $n=6 ; \mathrm{MC} ; n=5 ; \mathrm{MCT} ; \mathrm{n}=5$ ). Para análise estatística, foi utilizado o teste de oneway ANOVA, seguido pelo pós-teste de Tukey, sendo $\mathrm{p}<0,05(*)$. 
4.7 Análise da geração de células $\mathrm{CD}^{+} \mathrm{CD} 25^{+} \mathrm{FoxP}^{+}$(Tregs) por células dendríticas cocultivas com mastócitos.

Por apresentarem deficiência na estimulação de linfócitos, associada à maior expressão de CD25, avaliamos a capacidade de iDCs provenientes da co-cultura em monolayer com $\mathrm{MC}$ ou $\mathrm{MCT}$ quanto à geração de células $\mathrm{CD} 4^{+} \mathrm{CD} 25^{+} \mathrm{FoxP} 3^{+}$(Tregs), células capazes de criar um microambiente supressor. Assim, tanto iDC-MCs quanto iDC-MCTs foram retiradas das placas após 2 dias de co-cultivo, contabilizadas e utilizadas como estimuladoras de linfócitos $\mathrm{T} \mathrm{CD}^{+}$na proporção de $1 \mathrm{DC}$ : 10 linfócitos T (Figura 23).

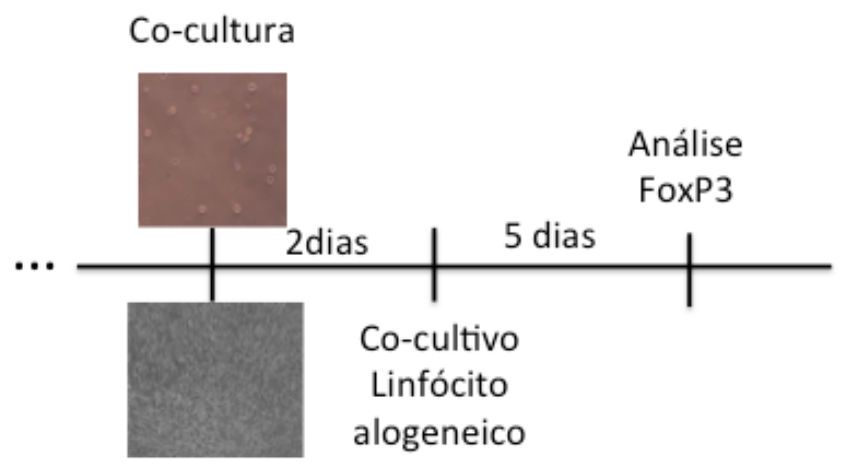

Figura 23. Representação gráfica do delineamento experimental para a análise da expressão de FoxP3 nas células T CD4+CD25+ co-cultivadas ou não com mastócitos. Após 2 dias co-cultivo de DC com MCs (5:1), as células foram retiradas da placa, quantificadas e postas em co-cultura com linfócito $\mathrm{T}$ separados previamente por seleção imunomagnética (1:10). As células permaneceram em cultura por 5 dias. Transcorrido o tempo de cultivo, as células foram marcadas extracelularmente com CD4 e CD25, após, foram fixadas e permeabilizadas para marcação intracelular de FoxP3.

Nossos resultados indicam que, dentre as células $\mathrm{CD} 4{ }^{+} \mathrm{CD} 25^{+}$oriundas do co-cultivo de iDC (controle experimental), apenas 11,38 \pm 9,90\% expressavam FoxP3 contra 60,04 \pm $10,01 \%$ quando co-cultivadas com iDC-MC e 65,08 $\pm 12,91 \%$ quando co-cultivadas com iDC-MCT (Figura 23). 
A
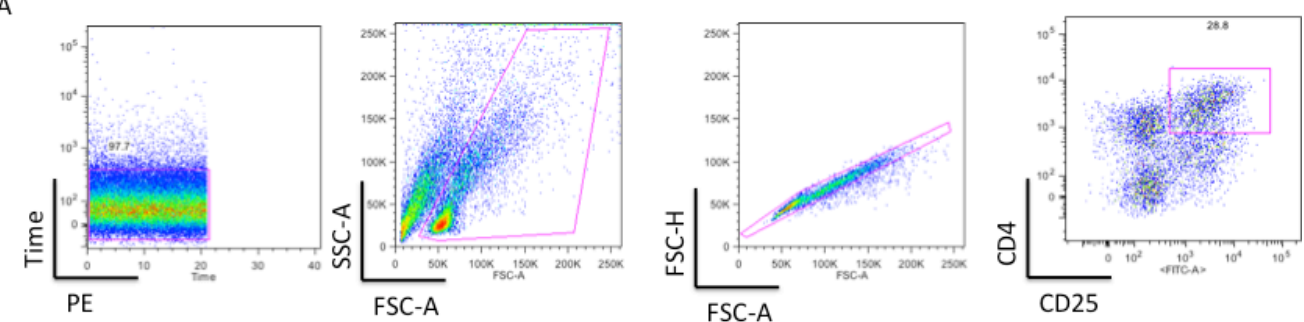

$\mathrm{CD}^{+} \mathrm{CD}^{+}{ }^{+} \mathrm{CD} 25^{+} \mathrm{FoxP} 3^{+}$
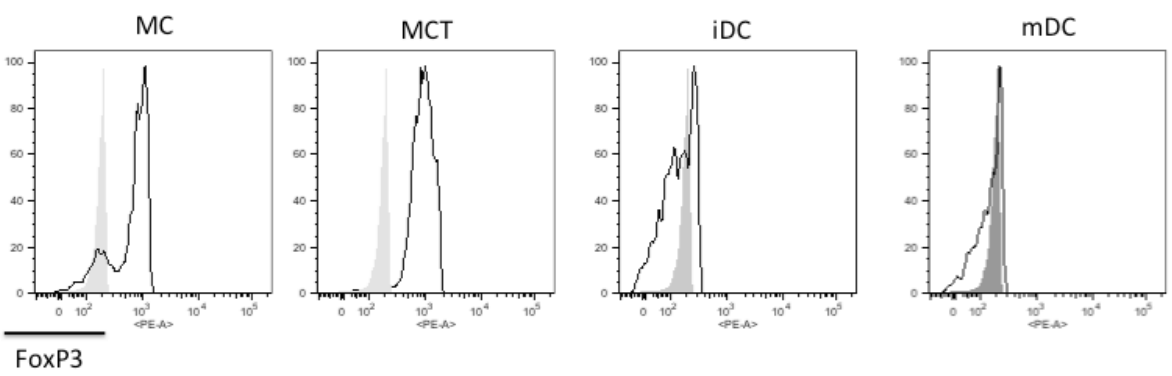

B

$\mathrm{CD}^{+} \mathrm{CD} 25^{+} \mathrm{FOXP} 3^{+}$

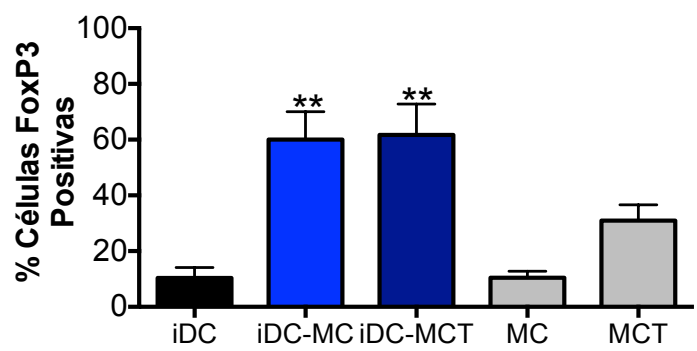

Figura 24. Avaliação da expressão de FoxP3 nas células CD3+CD4+CD25+ quando estes linfócitos foram co-cultivados ou não com iDC previamente co-cultivas com mastócitos (nos diferentes grupos experimentais). Linfócitos $\mathrm{T}$ alogênicos foram isolados por seleção imunomagnética e co-cultivados com iDC, iDC previamente co-cultivadas com mastócitos (iDC-MCs), iDCs cultivadas com mastócitos sensibilizados com HCT-116 (iDC-MCT), cultivados apenas com mastócitos (MC) ou com mastócitos sensibilizados com a linhagem tumoral HCT-116 (MCT). (A) Primeiramente, demonstramos a estratégia de análise estabelecida, sendo que, primeiro, avaliamos a alteração do laser azul (time versus PE), e foram selecionados apenas os eventos que exibiram uma distribuição homogenia. Após, selecionamos as células por seu tamanho e sua granulosidade (FSC versus SSC), sendo escolhida a população referente aos linfócitos, depois, foram excluídos os eventos duplos, pelo gate FSC-A versus FSC-H. Apenas dentro dos eventos únicos analisamos a expressão das moléculas CD4+ e CD25+, sendo selecionadas apenas as células duplo positivas para estes marcadores. Por último, analisamos a frequência de FoxP3 dentre as células duplo positivas; sendo representado, nos histogramas, em que cinza se refere ao grupo FMO e a linha preta, à intensidade nos diferentes grupos. (B) Representação gráfica da frequência de FoxP3 dentre as células $\mathrm{CD} 4{ }^{+} \mathrm{CD} 25^{+}$; (iDC; $\mathrm{n}=6$; iDC-MC; $\mathrm{n}=6$; iDCMCT; $\mathrm{n}=5 ; \mathrm{MC} ; \mathrm{n}=9 ; \mathrm{MCT} ; \mathrm{n}=1$ ), para análise estatística, foi utilizado o teste de ANOVA, seguido pelo pósteste de Tukey, sendo $\mathrm{p}<0,01(* *)$.

Vale realçar que células $\mathrm{T}$ ativadas são capazes de aumentar a expressão do fator de transcrição FoxP3, o que poderia invalidar a hipótese de indução de células Treg. No entanto, observamos que o cultivo parece não alterar a expressão de CD127 (Receptor $\alpha$ de IL-7), 
assim, sugerindo que estes linfócitos T estavam igualmente ativados (em relação ao controle) (Figura 25).
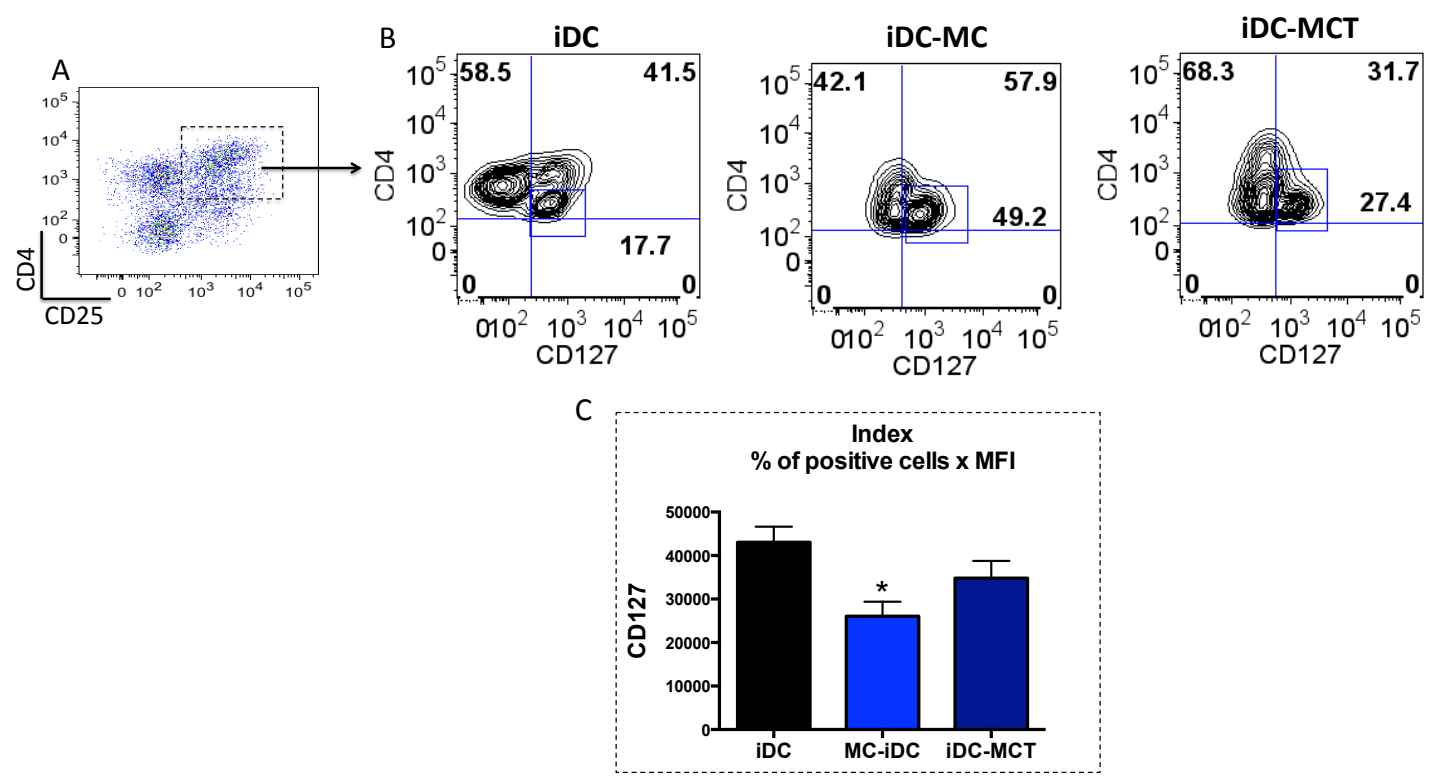

Figura 25. Gráfico representativo da expressão de $\mathrm{CD} 127$ pelas células $\mathrm{CD}^{+} \mathrm{CD}^{+} \mathrm{CD}^{2} 5^{+}$. Linfócitos $\mathrm{T}$ alogênicos foram isolados por seleção imunomagnética e co-cultivados com iDC previamente co-cultivadas com mastócitos (iDC-MC), mastócitos sensibilizados com HCT-116 (iDC-MCT) ou iDC. Primeiramente, avaliamos a alteração do laser azul (time versus PE), e foram selecionados apenas os eventos que exibiram uma distribuição homogenia. Após, selecionamos as células por seu tamanho e sua granulosidade (FSC versus SSC), sendo escolhida a população referente aos linfócitos, depois, foram excluídos os eventos duplos, pelo gate FSCA versus FSC-H. Apenas dentro dos eventos únicos, analisamos a expressão das moléculas CD4+ e CD25+, sendo selecionadas apenas as células duplo positiva para estes marcadores (A). Por último, analisamos a frequência de CD127 dentre as células duplo positivas (B), e, em C, apresentamos o índex que leva em consideração frequência e o MFI do CD127 (iDC; n=3; MC; n=3; MCT; n=3); para análise estatística, foi utilizado o teste de ANOVA, seguido pelo pós-teste de Tukey, sendo $\mathrm{p}<0,05\left(^{*}\right), \mathrm{p}<0,01(* *)$ e $\mathrm{p}<0,001(* * *)$.

Ainda, com o intuito de verificar se tal fenômeno era dependente do estado imaturo das DCs, adicionamos TNF- $\alpha$ na co-cultura - com o intuito de ativar as DCs -, nestes grupos, observamos que, em iDC-MC, a adição desta citocina interrompeu o comprometimento da expressão de FoxP3 nos linfócitos $(10,37 \pm 4,981 \%)$, no entanto, mesmo com a adição de TNF- $\alpha$, iDC-MCT, ainda induziram maior expressão de FoxP3 $(40,83 \% \pm 21,52)$ nas células $\mathrm{CD} 4{ }^{+} \mathrm{CD} 25^{+}$(Figura 26), sugerindo que as iDC-MCT induzem a expressão de FoxP3 (linfócitos) de maneira estável. 


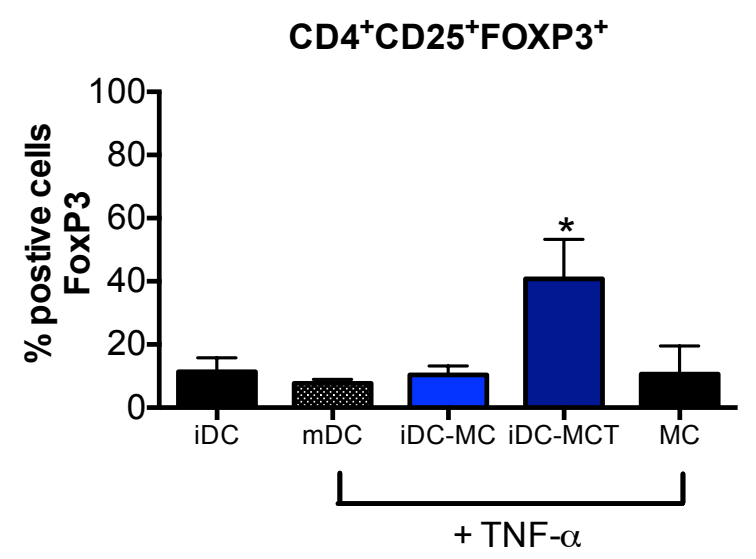

Figura 26. Gráfico representativo da expressão de $\mathrm{FoxP3}$ pelas células $\mathrm{CD}^{+} \mathrm{CD}^{+} \mathrm{CD}^{2} 5^{+}$. Linfócitos $\mathrm{T}$ alogênicos foram isolados por seleção imunomagnética e co-cultivados com iDC controle, $\mathrm{mDC}$ (estimuladas com $50 \mathrm{ng} / \mathrm{mL}$ de TNF- $\alpha$ ), iDC-MC estimuladas com TNF- $\alpha$, iDC-MCT estimuladas com TNF- $\alpha$ ou mastócitos cultivados com linfócitos T e estimulados com TNF- $\alpha$ (MC). Primeiramente, avaliamos a alteração do laser azul (time versus $\mathrm{PE}$ ), e foram selecionados apenas os eventos que exibiram uma distribuição homogênica. Após, selecionamos as células por seu tamanho e sua granulosidade (FSC vs SSC), sendo escolhida a população referente aos linfócitos, depois, foram excluídos os eventos duplos, pelo gate FSC-A versus FSC-H. Apenas dentro dos eventos únicos, analisamos a expressão das moléculas CD4+ e CD25+, sendo selecionadas apenas as células duplo positiva para estes marcadores. Como parâmetro de controle, utilizamos a intensidade de fluorescência do grupo FMO (não apresentado). iDC, $\mathrm{n}=2 ; \mathrm{mDC}, \mathrm{n}=2$; iDC-MC, $\mathrm{n}=2$; iDC-MCT, n=2; MC, $\mathrm{n}=2$. Para análise estatística, foi utilizado o teste de ANOVA, seguido pelo pós-teste de Tukey, sendo $\mathrm{p}<0,05\left(^{*}\right)$.

A adição de TNF- $\alpha$, no entanto, não recuperaram a expressão de HLA-DR, CD40 e CD209 das iDC-MC ou iDC-MCT. Mas, nota-se que o grupo iDC-MC após estímulo foi capaz de expressar CD86, CD1a e PD-L1 estatisticamente igual ao grupo de DCs maduras (iDC tratadas com TNF- $\alpha, \mathrm{mDC}$ ), mas isso não foi observado no grupo iDC-MCT (Figura 26); Neste grupo, observamos que, em comparação às mDCs, iDC-MCT estimuladas com TNF- $\alpha$, expressam significativamente menos HLA-DR, CD80, CD86, CD40 e CD209, associado ao aumento de PD-L1 e CD1a; assim, corroborando a maior estabilidade "tolerogênica" das DCs cultivadas com MCT. 

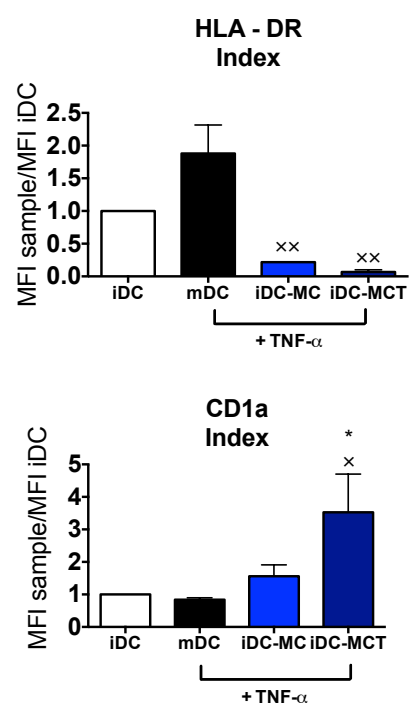
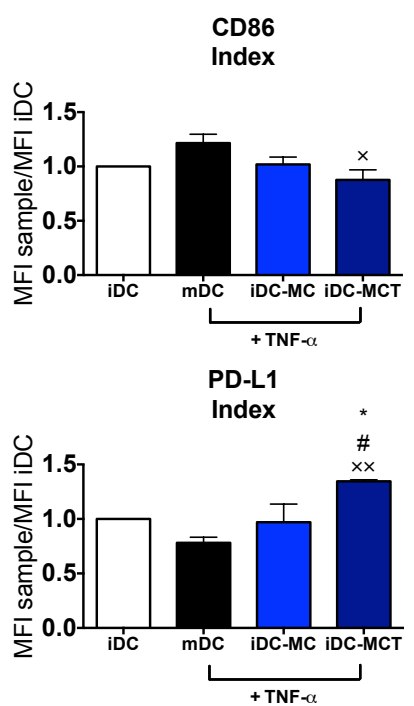
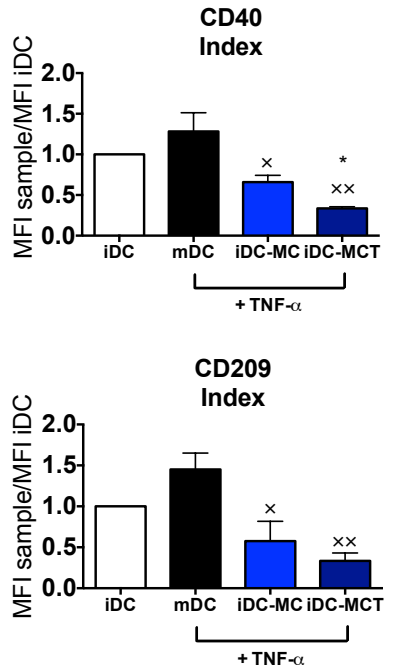

Figura 27. Gráficos do índex intensidade Mediana de Fluorescência (MFI) das células positivas quanto às moléculas de superfície em células dendríticas imaturas (controle), estimuladas com TNF- $\alpha$ (mDC) por 48 horas, co-cultivadas com mastócito em monolayer (iDC-MC), co-cultiva com mastócitos sensibilizados com a linhagem tumoral HCT-116 em monolayer (iDC-MCT), após cinco dias, foi adicionado $50 \mathrm{ng} / \mathrm{mL}$ de TNF- $\alpha$ (A) em cinco dias de cultura, as iDCs foram retiradas das placas, e replaquedas com MCs ou não. Após dois dias de cultivo, as células foram desafiadas com $50 \mathrm{ng} / \mathrm{mL}$ de TNF- $\alpha$, após 48 horas de adição, as células foram fenotipadas e analisadas comparativamente quanto à expressão de moléculas de superfície, iDC $(\mathrm{n}=5)$; $\mathrm{mDC}$ $(n=5)$, iDC-MC $(n=3)$; iDC-MCT $(n=3)$, para análise estatística, foi utilizado o teste de one-way ANOVA, seguido pelo pós-teste de Tukey, sendo $\mathrm{p}<0,05$ ( $\mathrm{x} / \# / *), \mathrm{p}<0,01$ ( $\mathrm{xx}$ ) e $\mathrm{p}<0,001$ ( $\mathrm{xxx}$ ). (*) quando diferente de iDC, (\#) se diferente de iDC-MC e $\mathrm{x}$ diferente de $\mathrm{mDC}$.

4.8 Análise de citocinas presentes no sobrenadante e marcação intracelular de IL-10 e TGF- $\beta$ dos linfócitos $\mathrm{T}$ provenientes do co-cultivo com células dendríticas dos diferentes grupos experimentais.

Em virtude dos fenômenos encontrados quanto ao aumento da expressão $\mathrm{FoxP}^{+} \mathrm{em}$ células $\mathrm{CD}^{+} \mathrm{CD}^{+} \mathrm{CD} 25^{+}$, nos perguntamos se as interações celulares e mediadores presentes na co-cultura poderiam modular o padrão de citocinas secretadas pelos linfócitos $\mathrm{T}$ alogênicos. Para tal, analisamos o sobrenadante de cinco dias de co-cultivo - DCs provenientes do diferentes grupos experimentais e linfócitos - , quanto à presença de IL-2, IFN- $\gamma$, IL-4, IL-6 e IL-10. Primeiramente, observamos que o grupo iDC-MC demonstrou significativa diminuição de IL-2 quando comparado com o grupo de iDC controle, sugerindo maior consumo desta citocina (Figura 27), sem resultar na maior proliferação, corroborando a hipótese de indução de Tregs. Em contrapartida, não observamos menor quantidade desta citocina no grupo iDC-MCT, no entanto, ainda assim, a presença desta citocina não resultou na proliferação de linfócitos T (Figura 20). Curiosamente, notamos que a adição de TNF- $\alpha$ à cultura - estímulo para maturação de DC - foi capaz de anular ou atenuar o fenômeno de indução de Treg no grupo iDC-MC devido à menor expressão de FoxP3 (descrita acima), bem 
como a maior produção de IL-2, mas isso não ocorreu no grupo iDC-MCT, corroborando com a hipótese de que o contato prévio dos MCs com a linhagem tumoral resultou na indução de FoxP3 mais estável (dados não apresentados).

Ainda em relação às citocinas, produzidas por linfócitos, notamos que, no sobrenadante da cultura de linfócitos, o grupo da co-cultura de iDC-MC e iDC-MCT resultou no aumento de IL-6, sendo iDC-MC $\pm 157,6$ pg/mL e $\pm 206,6$ pg/mL em iDC-MCT contra $\pm 22,40 \mathrm{pg} / \mathrm{mL}$ do grupo iDC. Embora não significativo, observamos uma tendência de aumento na presença de IFN- $\gamma$, e, coerentemente com este resultado, nota-se a diminuição significativa da presença de IL-4 (Figura 28).

IL-2

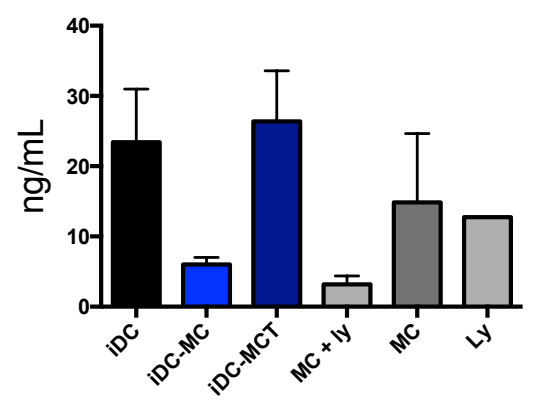

IL-4

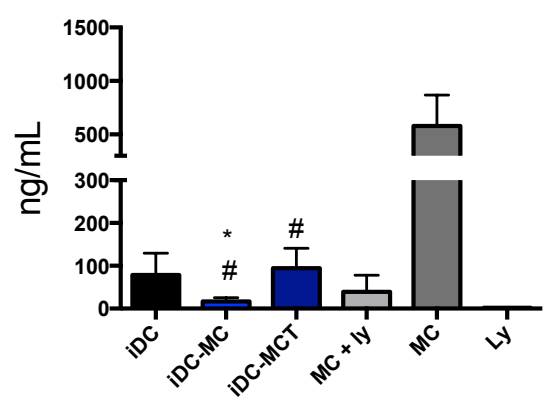

IFN- $\gamma$

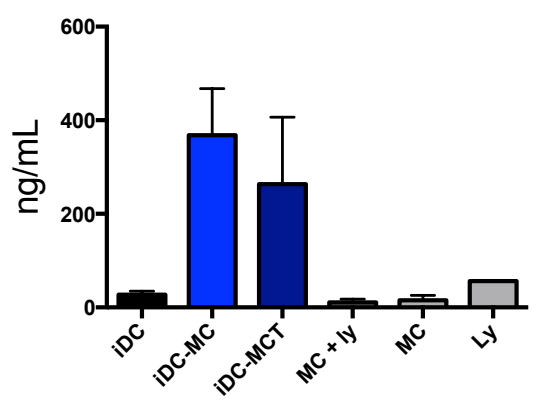

IL-6

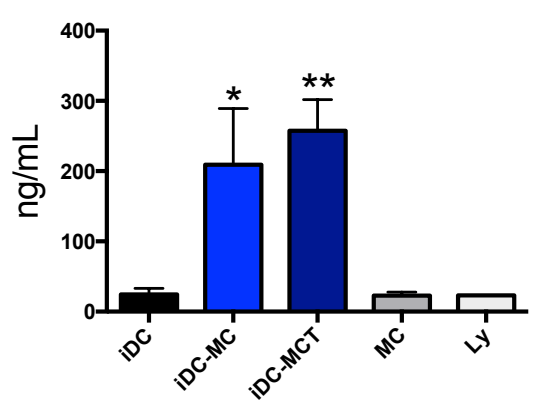

Figura 28. Quantificação das citocinas presentes no sobrenadante da co-cultura de linfócitos $T$ alogênicos imunomagneticamente separados com iDC provenientes dos grupos experimentais. O sobrenadante da cocultura de linfócitos T cultivado com iDC, iDC co-cultivada com mastócito (iDC-MC), iDC co-cultivada com MCT (iDC-MCT) e mastócito (MC + Ly), ou o sobrenadante da cultura de mastócito (MC) ou linfócitos T (Ly) foi retirado após cinco dias de cultura e analisada por citometria de fluxo (CBA) a presença das citocinas IL-2, IFN- $\gamma$, IL4 e IL-6; (iDC, n=7; iDC-MC, n=3; iDC-MCT, n=5; MC, $n=3$; MC + ly; $n=3 ;$ Ly; $n=2$ ), para análise estatística, foi utilizado o teste de ANOVA, seguido pelo pós-teste de Tukey, sendo $\mathrm{p}<0,05(*), \mathrm{p}<0,01(* *)$ e $\mathrm{p}<0,001(* * *)$, sendo * diferente de iDC e \# de MC.

Infelizmente, não foi possível detectar no sobrenadante das culturas níveis aceitáveis de IL-10. No entanto, considerando a hipótese do aumento de células Treg e sabendo que 
estas são potentes produtoras de IL-10, nos perguntamos se esta citocina não poderia ser consumida rapidamente pelas células em cultura e por isso não detectadas no sobrenadante, sendo assim, com o intuito de verificar a produção de IL-10 por linfócitos co-cultivados com iDC-MC ou iDC-MCT, realizamos ensaio de marcação de intracelular desta citocina (em linfócito). Para tal, iDC-MC ou iDC-MCT foram co-cultivas com linfócitos T alogênicos respeitando a proporção 1 DC: 10 Linfócitos T, tal co-cultura permaneceu por 5 dias. No quinto dia de cultura, as células foram tratadas com brefeldina $\mathrm{A}(1 \mu \mathrm{L} / \mathrm{mL})$ para bloqueio da liberação de vesículas. Após $6 \mathrm{~h}$ de tratamento, as células foram removidas, quantificadas e marcadas.

Conforme esperado, notamos que apenas $15,74 \pm 11,59 \%$ das células $\mathrm{CD} 4{ }^{+} \mathrm{CD} 25^{+} \mathrm{FoxP}^{+}$provenientes do co-cultivo com iDC produziam IL-10, enquanto, no grupo de iDC-MC, os linfócitos apresentaram a frequência de 53,30 \pm 7,10 e, em iDC-MCT, $80,83 \pm 2,13 \%$, sugerindo que o co-cultivo com MCs parece induzir as iDCs para um perfil mais tolerogênico, sendo este mais efetivo quando os MCs foram expostos previamente à linhagem tumoral HCT-116 (iDC-MCT). Ainda em relação à produção de IL-10, observamos que, quando co-cultivamos iDCs expostas à linhagem de mastocitoma (HMC-1.1) com linfócitos T, este também expressaram altos níveis de IL-10 (71,35 $\pm 1,76 \%$ ) (Figura 29). 

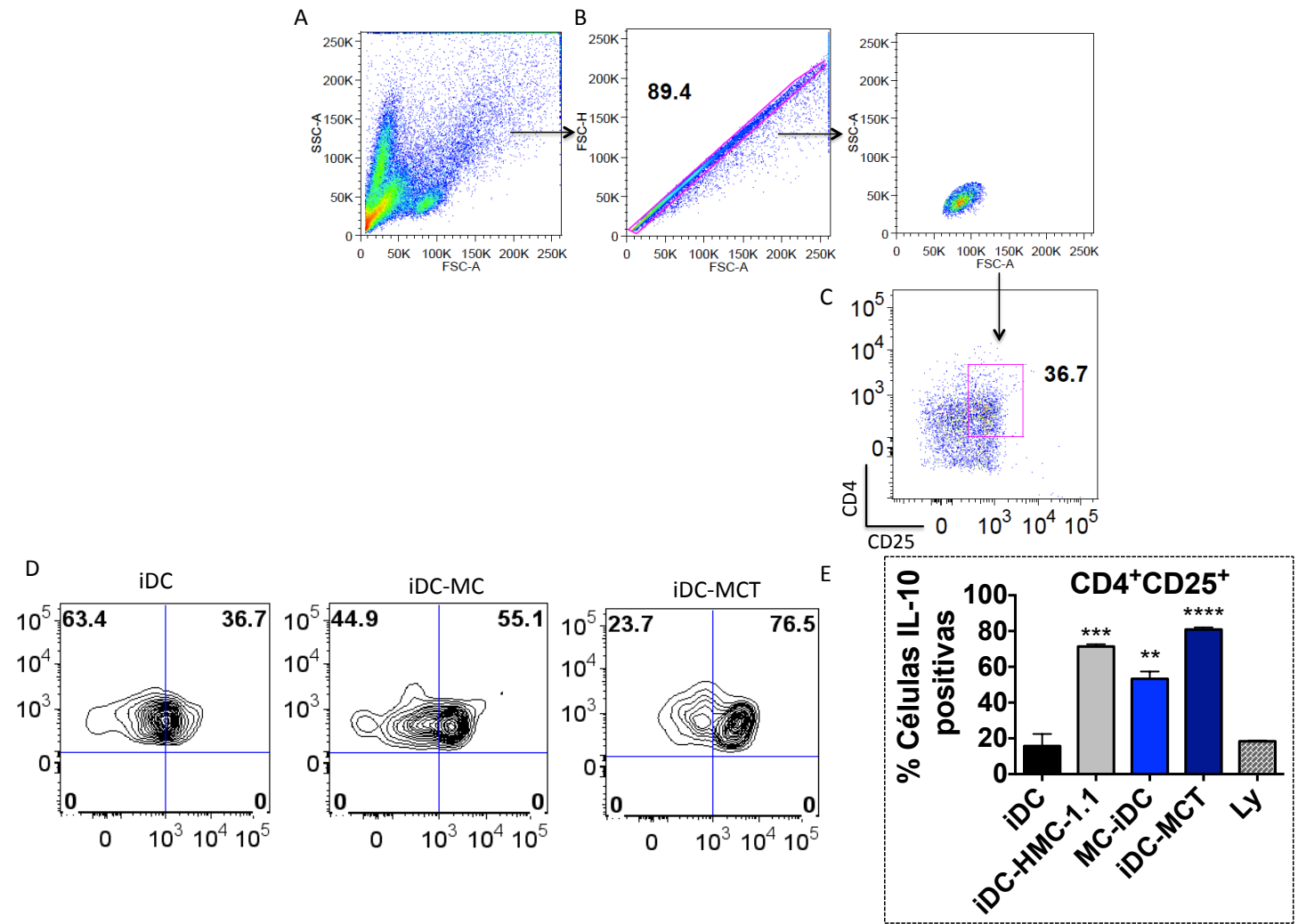

Figura 29. Avaliação da produção de IL-10 por linfócitos T co-cultivas com iDCs dos diferentes grupos experimentais. (A) Estratégia de análise utilizada para avaliação da presença intracelular de IL-10, primeiramente, foram isolados os eventos duplos pelo gate de FSC-A versus FSC-H (B), após as células com tamanho e granulosidade referentes a linfócitos, foram selecionadas e, nesta população, foi avaliada a presença de células positivas para CD4 e CD25 (C). Assim, apenas na população duplo-positiva analisamos a frequência de células também positivas para IL-10, foi utilizado o isótopo-controle do anticorpo como parâmetro de marcação negativa e desenho do gate. (E) Representação gráficas dos resultados obtidos, sendo utilizado o teste de ANOVA seguido pelo pós-teste Tukey, em que * $\mathrm{p}^{*}<0,05, * *=\mathrm{p}<0,01, * * *=\mathrm{p}<0,001$ e $* * * *=\mathrm{p}<0,0001$. iDC, $n=4$; iDC-MC, $n=4$; iDC-MCT, $n=3$.

Além da produção de IL-10, foi também verificada a capacidade de síntese de TGF- $\beta$ por linfócitos T, observamos, assim, que a expressão do TGF- $\beta$ no grupo iDC era equivalente a $34,11 \pm 12,61 \%$ contra $74,57 \pm 15,83$ em iDC-MC e $87,50 \pm 0,21 \%$ em MCT. Embora tenhamos notado um aumento significativo deste fator de crescimento, ao compararmos os linfócitos T co-cultivados com iDC contra os co-cultivados tanto com iDC-MC quanto iDCMCT, notamos, no entanto, que mesmo sem estímulo, os linfócitos $\mathrm{T}$ expressavam grande quantidade de TGF- $\beta$ em seu citoplasma (Figura 30), impossibilitando, assim, a conclusão de que seja um aumento mastócito-dependente. Portanto, tais dados sugerem que o co-cultivo em monolayer de MCs com iDCs pode gerar linfócitos Treg induzido com perfil Tr1. 
A

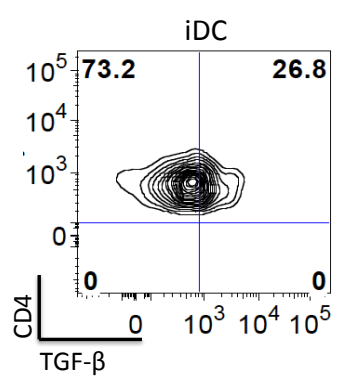

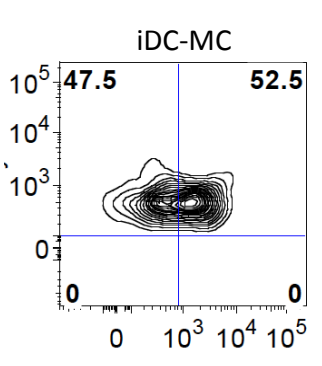

B

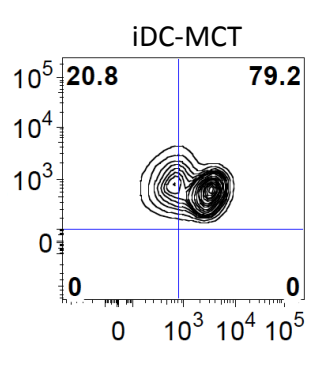

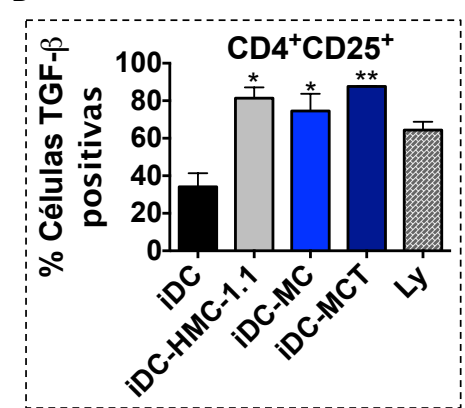

Figura 30. Avaliação da produção de TGF- $\beta$ por linfócitos T co-cultivas com iDCs dos diferentes grupos experimentais. Estratégia de análise utilizada para avaliação da presença intracelular de TGF- $\beta$, primeiramente, foram isolados os eventos duplos pelo gate de FSC-A versus FSC-H, após, as células com tamanho e granulosidade referentes a linfócitos foram selecionadas e, nesta população, foi avaliada a presença de células positivas para CD4 e CD25. Assim, apenas na população duplo-positiva, analisamos a frequência de células também positivas para TGF- $\beta$, foi utilizado o isótopo-controle do anticorpo como parâmetro de marcação negativa e desenho do gate. Representação gráficas dos resultados obtidos, sendo utilizado o teste de ANOVA seguido pelo pós-teste Tukey, em que $*=\mathrm{p}<0,05, * *=\mathrm{p}<0,01, * * *=\mathrm{p}<0,001 \mathrm{e}^{* * * *}=\mathrm{p}<0,0001$. iDC, $\mathrm{n}=4$; iDC-MC, n=4; iDC-MCT, $\mathrm{n}=3$.

\subsection{Avaliação da supressão promovida por células $\mathrm{CD} 3^{+} \mathrm{CD} 4^{+} \mathrm{CD} 25^{+}$.}

Após observação de que iDCs provenientes da co-cultura com MCs e MCTs têm maior habilidade em gerar células $\mathrm{CD} 4^{+} \mathrm{CD} 25^{+} \mathrm{Foxp} 3^{+}$que iDCs controle, associado à menor expressão de CD127, proliferação de linfócitos T alogênicos, e maior produção de IL-10 e TGF- $\beta$, se fez necessário avaliar se tais células geradas na co-cultura possuíam funções que as caracterizassem como pertencentes à população de Treg. Desse modo, avaliamos se estas células eram capazes de suprimir a proliferação de linfócitos $\mathrm{T} \mathrm{CD}^{+}$nä̈ve estimuladas com PHA, tal dado sustentaria a hipótese de que células FoxP3 ${ }^{+}$são, de fato, Treg.

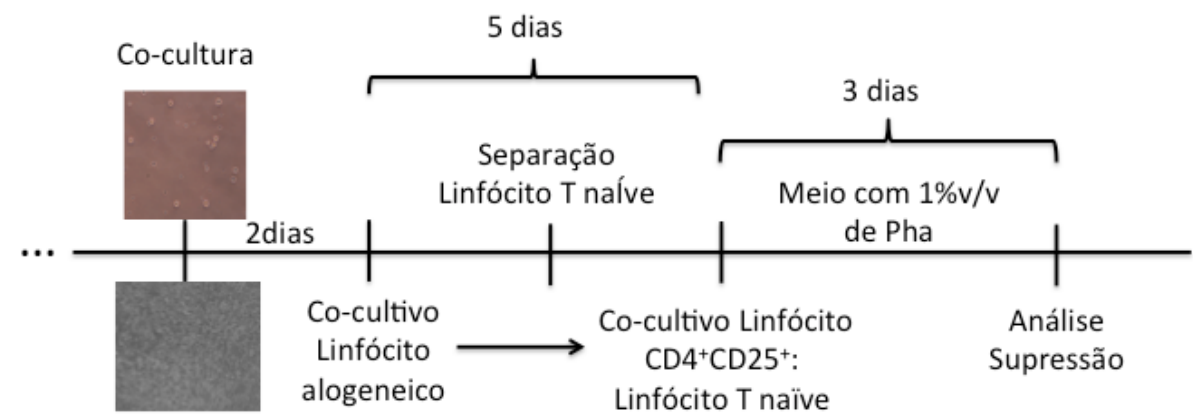

Figura 31. Representação gráfica do delineamento experimental para análise de supressão da proliferação de linfócitos T CD4 ${ }^{+}$nä̈ve. Após 2 dias co-cultivo de DC com MCs (5:1), as células foram retiradas da placa, quantificadas e postas em co-cultura com linfócito $\mathrm{T}$ separados previamente por seleção imunomagnética (1:10). As células permaneceram em cultura por 5 dias. Transcorrido o tempo de cultivo, as células $\mathrm{CD} 4{ }^{+} \mathrm{CD} 25^{+}$foram isoladas e co-cultivas com linfócitos T Naïve, previamente coradas com cell tracer violeta (CTV), as células foram estimuladas com PHA e, após 3 dias de co-cultivo, analisamos a diluição do CT. 
Assim, células $\mathrm{CD}^{+} \mathrm{CD} 25^{+}$geradas nas co-culturas de iDC com linfócitos $\mathrm{T}$ alogênicos foram isoladas por beads magnéticas e co-cultivadas por 3 dias em contato com linfócitos $\mathrm{T}$ naïve (alogênicos) previamente corados com Cell Trace violeta (CTV) e sob ativação por PHA. No terceiro dia de cultura, os linfócitos foram removidos da placa e a diluição do corante nas células-alvo (Linfócito $\mathrm{TCD}^{+}$naïve) foi avaliada por citometria de fluxo, sendo o delineamento experimental empregado demonstrado na Figura 31.

Assim, nossos dados revelaram que as células $\mathrm{CD}^{+} \mathrm{CD} 4{ }^{+} \mathrm{CD} 25^{+}$geradas em cocultura com iDC-MC ou iDC-MCT são capazes de suprimir a proliferação das células-alvo (linfócitos T naïve). Ainda, nossos resultados indicam que a supressão foi realmente induzida pelas células $\mathrm{CD} 3^{+} \mathrm{CD} 4^{+} \mathrm{CD} 25^{+}$, pois, ao modificar a proporção das células efetoras, ou seja, ao modificarmos a proporção para $1 \mathrm{CD}^{+} \mathrm{CD} 4^{+} \mathrm{CD} 25^{+}$(efetoras): 5 células-alvo, observamos aumento da proliferação das células-alvo (Figura 32).
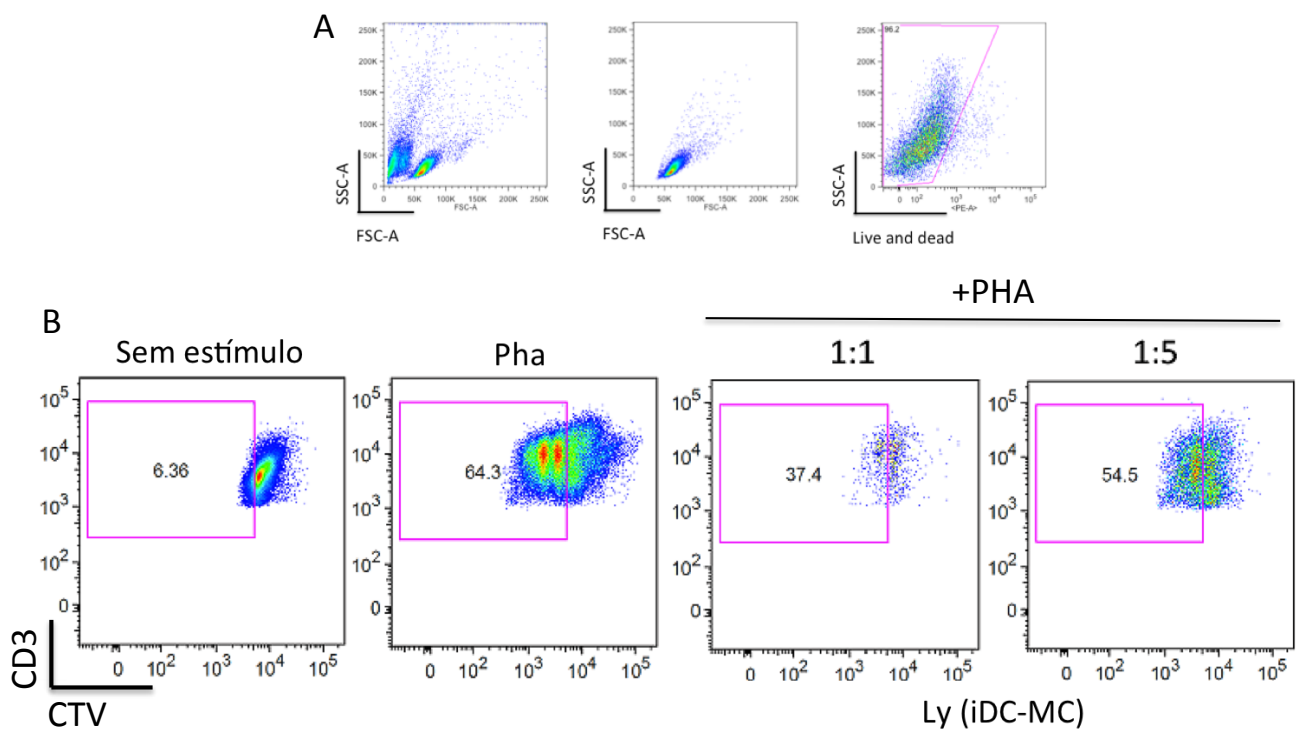

Figura 32. Avaliação da capacidade supressora dos linfócitos $\mathrm{CD3}^{+} \mathrm{CD}^{+} \mathrm{CD}^{+}$oriundos do co-cultivo com iDC-MC. Linfócitos T alogênicos foram co-cultivados por 5 dias com DCs provenientes do co-cultivo MC. Transcorrido o tempo de estímulo, foram isolados por separação imunomagnética as células CD4+CD25+, estas foram, então, co-cultivadas com Linfócitos T CD4+ naïve previamente corados com Cell Tracer Violeta e estimulados com PHA (1\% volume/volume). Em (A), mostramos a estratégia utilizada para definição celular alvo, para tal, consideramos, primeiramente, o tamanho e a granulosidade referente a linfócitos e células vivas (exclusão das células positivas para Live and dead). Assim, apenas dentro das células vivas e $\mathrm{CTV}^{+} \mathrm{CD}^{+}$, analisamos a diluição do corante. 
Além disso, nota-se que as células $\mathrm{CD} 3^{+} \mathrm{CD} 4{ }^{+} \mathrm{CD} 25^{+}$provenientes do co-cultivo de linfócitos com iDCs (lyiDC) não demonstraram função supressora, independente da concentração de células efetoras utilizadas (Figura 33).
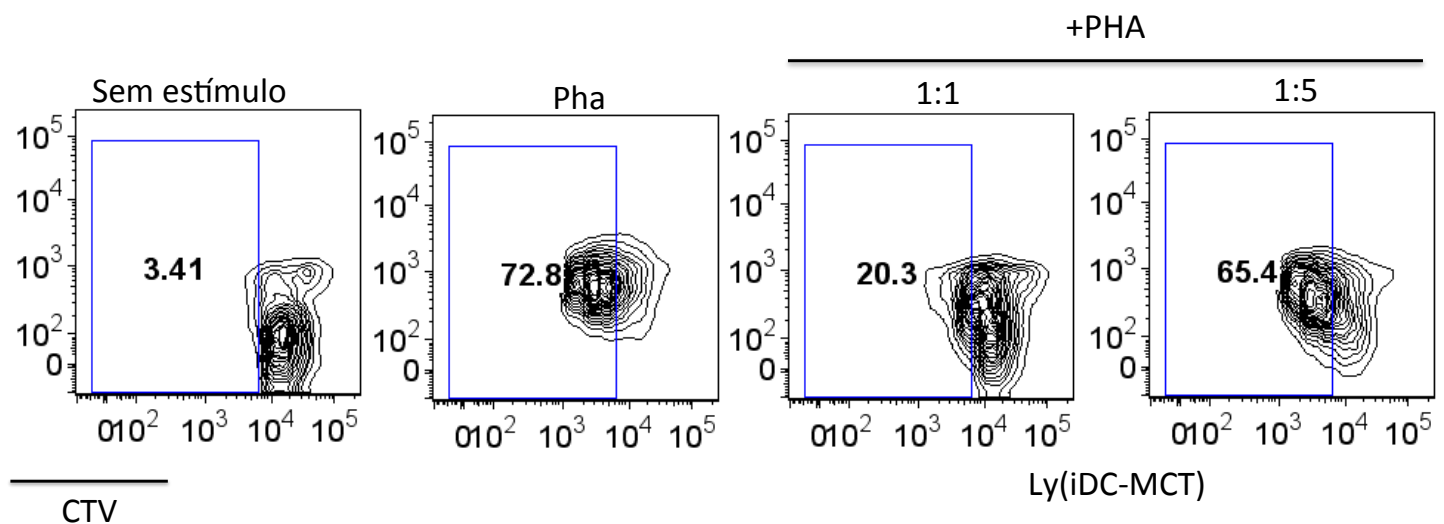

Figura 33. Avaliação da capacidade supressora dos linfócitos $\mathrm{CD}^{+} \mathrm{CD}^{+} \mathrm{CD25}{ }^{+}$oriundos do co-cultivo com iDC-MCT. Linfócitos T alogênicos foram co-cultivados por 5 dias com DCs provenientes do co-cultivo MCT. Transcorrido o tempo de estímulo, foram isolados por separação imunomagnética as células CD4+CD25+, estas foram, então, co-cultivadas com Linfócitos T CD4+ naïve previamente corados com Cell Trace Violeta e estimulados com PHA (1\% volume/volume). Como estratégia de gate, consideramos, primeiramente, o tamanho e a granulosidade referente a linfócitos e células vivas (exclusão das células positivas para Live and dead). Assim, apenas dentro das células vivas e $\mathrm{CTV}^{+} \mathrm{CD}^{+}$, analisamos a diluição do corante.
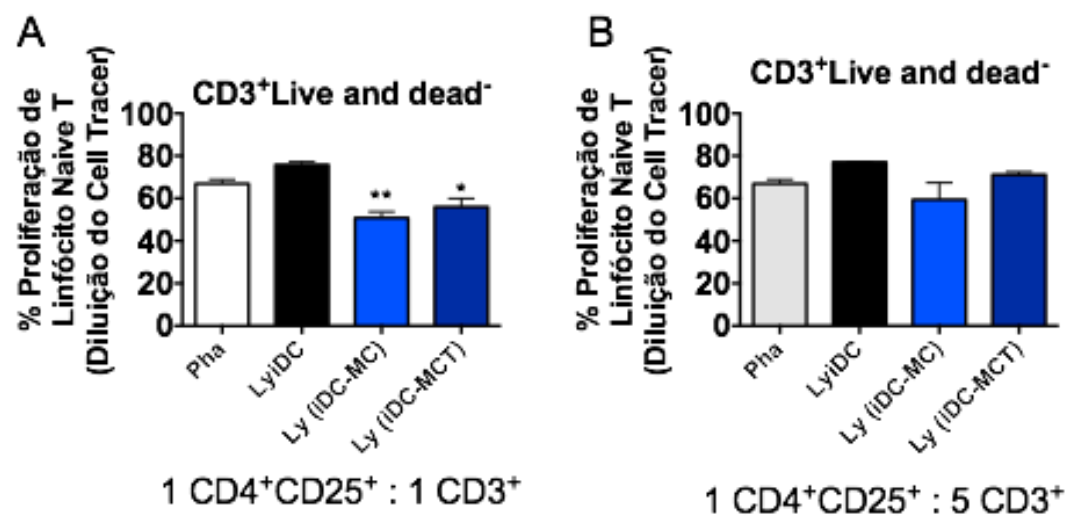

Figura 34. Representação gráfica da supressão promovida pelos linfócitos CD3+CD4+CD25+ cocultivadas com linfócitos $T$ nä̈ve e estimulados com PHA. (A) Dados referentes quando respeitada a proporção de 1 linfócito $\mathrm{T}$ nä̈ve para 1 linfócitos $\mathrm{CD} 3+\mathrm{CD} 4+\mathrm{CD} 25+$ oriundos dois diferentes grupos experimentais. (B) Dados referentes quando respeitada a proporção de 5 linfócito $\mathrm{T}$ nä̈ve para 1 linfócitos $\mathrm{CD} 3+\mathrm{CD} 4+\mathrm{CD} 25+$ oriundos de dois diferentes grupos experimentais, mostrando, assim, o efeito células dependente. iDC;n=4; MC;n=3; MCT; $n=4$; para análise estatística, foi utilizado o teste de ANOVA, seguido pelo pós-teste de Tukey, sendo $\mathrm{p}<0,05(*), \mathrm{p}<0,01(* *)$ e $\mathrm{p}<0,001(* * *)$. 
4.10 Co-cultura de células dendríticas e mastócito em um sistema com restrição de contato (Transwell).

Conforme demonstrado nos experimentos anteriores, notamos que a presença de MCs sensibilizados ou não com células tumorais parece modular as DCs para um perfil tolerogênico (tDCs). Estas, por sua vez, foram capazes de induzir a polarização dos linfócitos $\mathrm{T}$ para o perfil regulador. Com intuito de verificar a importância do contato celular quanto à modulação das DCs, mantivemos o protocolo de diferenciação de ambas as células, bem como, o tempo de co-cultura. No entanto, utilizamos um sistema de cultura com restrição de contato (transwell), em que MCs foram plaqueados nos compartimentos superiores e as DCs aderidas no compartimento inferior.

Após dois dias de co-cultivos, observamos que, nestas condições, diferentemente dos resultados obtidos em monolayer, os mediadores produzidos pelos MCs parecem modular o fenótipo das DCs para um perfil de maior ativação. Em que, ao considerar a frequência das moléculas de interesse, notamos uma diminuição significativa da expressão de PD-L1 pelas DCs, tanto iDC/MC quanto iDC/MCT (Tabela 3).

Tabela 3. Frequência das moléculas de superfície nos diferentes grupos de co-cultivo em transwell. Para a análise de significância estatística, foi utilizada a análise de variância one-way ANOVA seguida por Tukey, sendo $* * *=\mathrm{p}<0,001$ e diferente de iDC.

\begin{tabular}{|c|c|c|c|}
\multicolumn{2}{c}{ iDC } & iDC/MC & iDC/MCT \\
\hline Moléculas & \multicolumn{1}{c|}{ idulas } \\
\hline HLA-DR & $97,19 \pm 3,95$ & $99,20 \pm 1,12$ & $98,35 \pm 2,19$ \\
\hline CD1a & $45,27 \pm 17,68$ & $32,50 \pm 5,63$ & $34,81 \pm 12,29$ \\
\hline CD209 & $89,36 \pm 8,18$ & $82,39 \pm 14,98$ & $71,23 \pm 27,26$ \\
\hline CD83 & $29,77 \pm 15,35$ & $10,17 \pm 2,18$ & $26,01 \pm 11,87$ \\
\hline CD80 & $49,90 \pm 16,13$ & $47,03 \pm 5,35$ & $43,05 \pm 0,49$ \\
\hline CD86 & $79,65 \pm 18,45$ & $92,93 \pm 11,09$ & $89,10 \pm 17,15$ \\
\hline CD40 & $91,20 \pm 5,95$ & $83,8 \pm 10,83$ & $75,85 \pm 21,71$ \\
\hline CCR7 & $68,48 \pm 8,75$ & $58,41 \pm 15,23$ & $49,66 \pm 23,39$ \\
\hline PD-L1 & $70,95 \pm 14.07$ & $13,11 \pm 3,56(* * *)$ & $17,17 \pm 11,38(* * *)$ \\
\hline
\end{tabular}

Vale ressaltar que, assim como o perfil tolerogênico, o de ativação das DCs após cultura em transwell foi mais evidente ao observamos o índex da MFI (dados originais demonstrados na Tabela 4), neste, notamos que os mediadores produzidos por MCs ou MCTs resultou no aumento significativo da expressão de CD86 e CD83 (Figura 35). 
Tabela 4. MFI das moléculas de superfície nos diferentes grupos de co-cultivo em transwell. Para a análise de significância estatística, foi utilizada a análise de variância one-way ANOVA seguida por Tukey, sendo $*=\mathrm{p}<0,05$ e $* * *=\mathrm{p}<0,001$ e diferente de iDC.

\begin{tabular}{|c|c|c|c|}
\multicolumn{4}{c}{ iDC } \\
Moléculas & iDC/MC & iDC/MCT \\
\hline HLA-DR & $33690 \pm 13171$ & $34335 \pm 11458$ & $44313 \pm 11830\left(^{*}\right)$ \\
\hline CD1a & $757 \pm 341$ & $453,2 \pm 49,50$ & $463,3 \pm 92,98$ \\
\hline CD209 & $1873 \pm 976,2$ & $2880 \pm 732,1$ & $2619 \pm 104,2$ \\
\hline CD83 & $299,6 \pm 114,5$ & $1401 \pm 199,9\left(^{* * *}\right)$ & $1838 \pm 696,5$ \\
\hline CD80 & $473,6 \pm 149,9$ & $714,4 \pm 107,8$ & $613,0 \pm 154,1$ \\
\hline CD86 & $888,7 \pm 384,2$ & $20340 \pm 3906\left(^{* * *}\right)$ & $22581 \pm 9544\left(^{* * *}\right)$ \\
\hline CD40 & $1823 \pm 803,3$ & $2743 \pm 445,3$ & $2788 \pm 999,1$ \\
\hline CCR7 & $548,1 \pm 218,2$ & $699,5 \pm 165,9$ & $595,6 \pm 260,8$ \\
\hline PD-L1 & $473,7 \pm 95,79$ & $324,9 \pm 36,72$ & $395,3 \pm 124,1$ \\
\hline
\end{tabular}
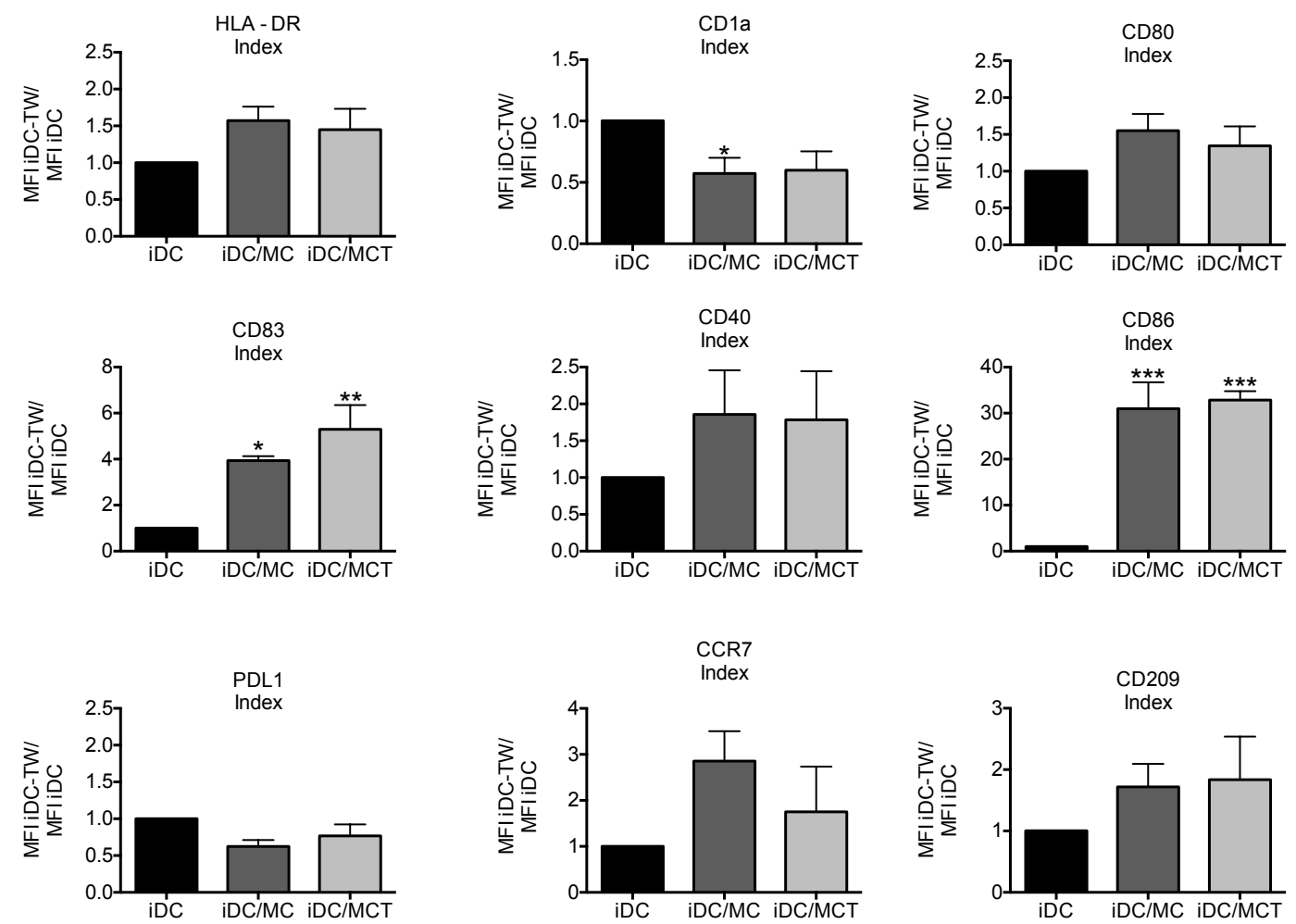

Figura 35. Gráficos do índex intensidade Mediana de Fluorescência (MFI) das células positivas quanto às moléculas de superfície em células dendríticas imaturas (iDC) (controle), co-cultivadas com mastócito em transwell (iDC/MC), co-cultiva com mastócitos sensibilizados com a linhagem tumoral HCT-116 em transwell (iDC/MCT). (A) No quinto dia de cultura, as iDCs foram retiradas das placas, e replaquedas com MCs ou não. Após dois dias de cultivo, as células foram fenotipadas e analisadas comparativamente quanto à frequência de moléculas de superfície, sendo o $\mathrm{iDC}(\mathrm{n}=5)$; $\mathrm{iDC} / \mathrm{MC}(\mathrm{n}=5)$; iDC/MCT $(\mathrm{n}=5)$ para análise estatística foi utilizado o teste de one-way ANOVA, seguido pelo pós-teste de Tukey, sendo $\mathrm{p}<0,05(*), \mathrm{p}<0,01$ $(* *)$ e $\mathrm{p}<0,001(* * *)$. 
Intrigantemente, notamos interessantes diferenças entre iDCs co-cultivadas com MCs em transwell ou com contato celular (monolayer), principalmente em relação a moléculas relacionadas ao co-estímulo e maturação de DCs, como, por exemplo, CD80 e CD86, sendo que estas foram mais expressas no grupo que não teve contato celular. Além disso, nos chama a atenção o aumento significativo de HLA-DR no grupo iDC/MC, em relação ao iDC-MC, e da molécula CD209 (Figura 36), sugerindo, assim, que as iDC/MC, provavelmente, possuem uma melhor capacidade linfoestimuladora e menor capacidade de geração de Tregs do que iDC-MC.
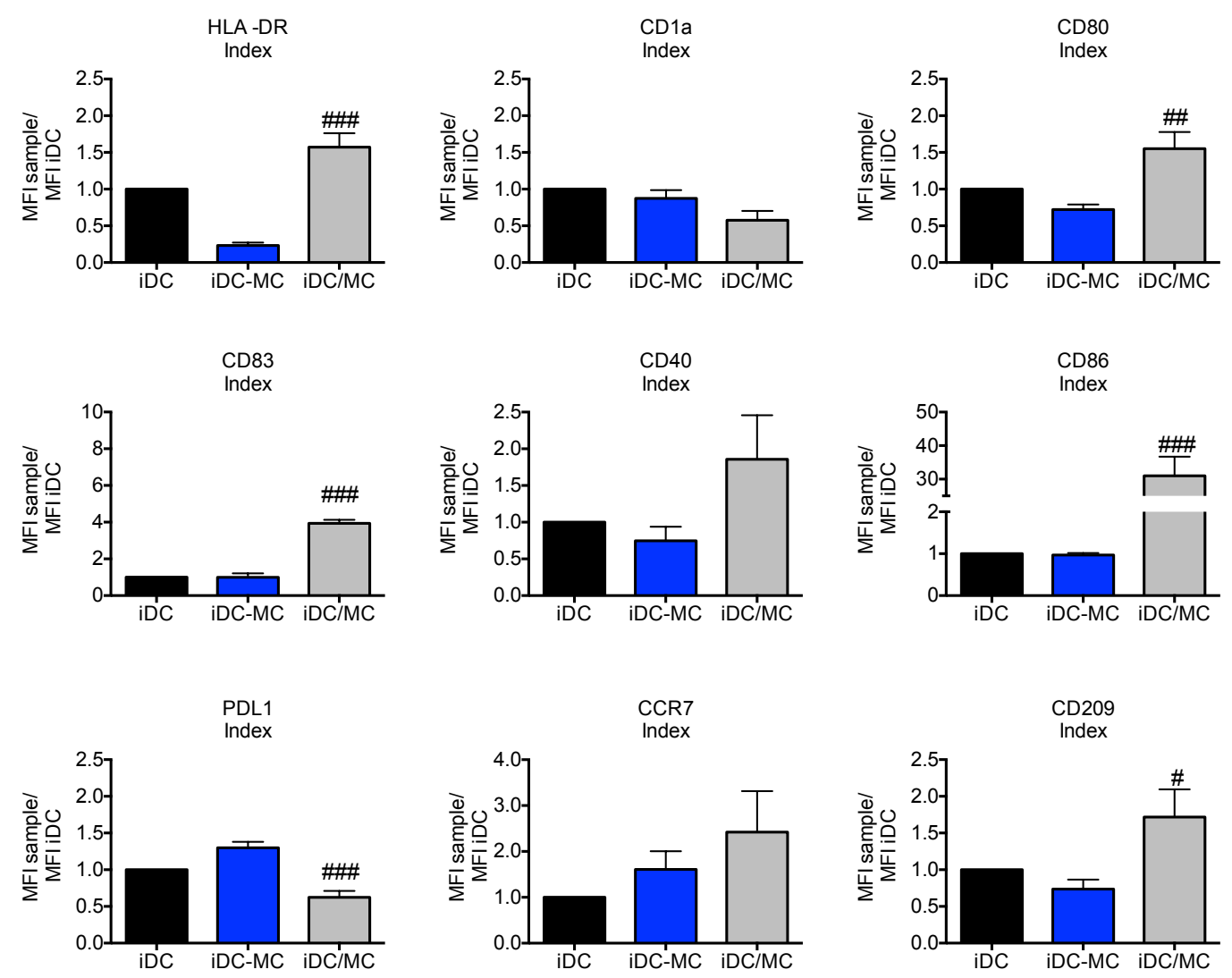

Figura 36. Gráficos do índex intensidade Mediana de Fluorescência (MFI) das células positivas quanto às moléculas de superfície em células dendríticas imaturas (iDC) (controle), co-cultivadas com mastócito em monolayer (iDC-MC) ou co-cultiva com mastócitos em transwell (iDC/MCT). (A) No quinto dia de cultura, as iDCs foram retiradas das placas, e replaquedas com MCs ou não. Após dois dias de cultivo, as células foram fenotipadas e analisadas comparativamente quanto à frequência de moléculas de superfície, sendo o iDC ( $n=5)$; iDC-MC ( $=5)$; iDC/MC $(n=5)$, para análise estatística, foi utilizado o teste de one-way ANOVA, seguido pelo pós-teste de Tukey, sendo $\mathrm{p}<0,05$ (\#), $\mathrm{p}<0,01$ (\#\#) e $\mathrm{p}<0,001$ (\#\#\#), em que \# representa diferença estatística entre iDC-MC e iDC-MCT. 
4.11 Análise da produção de citocinas por células dendríticas co-cultivas com $20 \%$ do sobrenadante de mastócito ou sobrenadante da co-cultura de mastócito com HCT-116.

Outro aspecto levado em consideração para a avaliação do estado de ativação das DCs foi a análise das citocinas presentes no sobrenadante após a co-cultura de dois dias. Assim, iDCs foram cultivadas com $20 \%$ do sobrenadante da cultura de HCT-116 (controle tumoral) (HCT-116), 20\% do sobrenadante da co-cultura de MCs com HCT-116 (SB Co-cultura) e $20 \%$ do sobrenadantes da cultura de MCs (SB Mastócito), como controle, analisamos as citocinas presentes no sobrenadante da cultura de mastócitos (MC). Após dois dias, o sobrenadante foi removido e analisada a presença de citocinas relacionadas à inflamação. Quanto à IL-8, supreendentemente, notamos que iDCs cultivadas na presença do sobrenadante da co-cultura de MCs com tumor (iDC + SB Co-cultura) foi significativamente menor do que nos outros grupos, ainda notamos que, nesta condição, as iDCs tinham uma tendência de aumento da produção de IL-6 e TNF- $\alpha$. Por outro lado, observamos que iDCs co-cultivadas com sobrenadante de MCs demonstraram uma tendência do aumento de IL-6 e um aumento significativo de IL-10. 

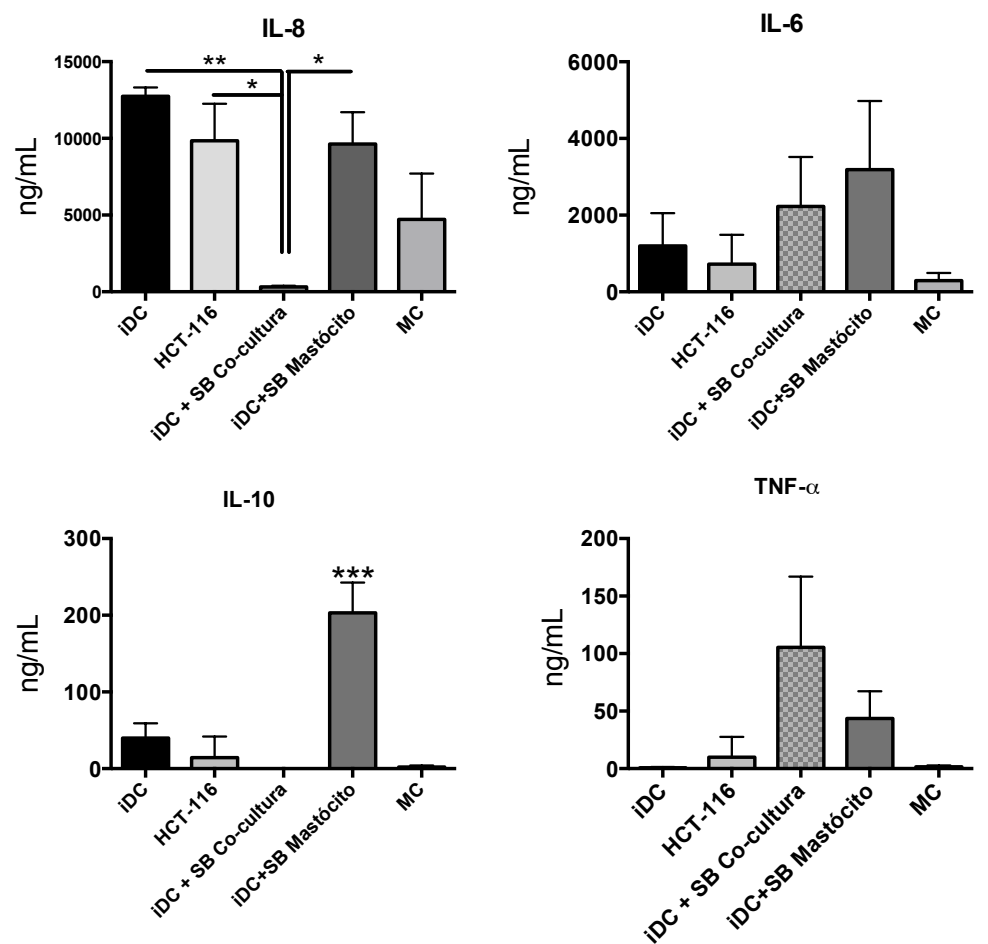

Figura 37. Quantificação das citocinas presentes no sobrenadante da cultura de iDC controle (iDC), estimulada com 20\% de sobrenadante de HCT-116 (HCT-116), 20\% do sobrenadante co-cultura de mastócito com HCT-116 (SB Co-cultura), 20\% do sobrenadante de Mastócito (SB Mastócito), como controle, observamos a presença das mesmas citocinas no sobrenadante de mastócito sem as células dendríticas (MC). Após cinco dias em cultura as iDCs, foram estimuladas com os diferentes sobrenadantes, e, após dois dias, analisamos a presença das citocinas IL-8, IL-1 $\beta$, IL-10 e IL-6 no sobrenadante das culturas ( $\mathrm{n}=4$ para todos os grupos experimentais), para análise estatística, foi utilizado o teste de ANOVA, seguido pelo pósteste de Tukey, sendo $\mathrm{p}<0,05(*), \mathrm{p}<0,01(* *)$ e $\mathrm{p}<0,001(* * *)$.

4.12 Avaliação da capacidade linfoestimuladora de células dendríticas cultivadas com mastócitos em um sistema com restrição de contato (transwell).

Embora o cultivo de iDC com sobrenadante de MCs tenha resultado no aumento de IL-10, observamos que o fenótipo das iDCs cultivadas com MCs em transwell apresentaram fenótipo de maior imunogenicidade, pois notamos o aumento da expressão de moléculas associadas à apresentação de antígenos e ativação de linfócitos. Portanto, analisamos se este fenótipo de maior ativação poderia refletir no aumento da capacidade das DCs em estimular linfócitos $\mathrm{T}$ alogenênicos.

Diferente do observado quando linfócitos foram co-cultivados com iDC-MC ou iDCMCT, não notamos diferenças significativas na capacidade linfoestimuladora das iDC em relação à iDC/MC ou iDC/MCT. No entanto, apesar do fenótipo de ativação, provavelmente, devido ao aumento da presença de IL-10, a capacidade linfoproliferativa exercida tanto por 
iDC/MC quanto por iDC/MCT não foi maior do que a estimulada pelas iDCs (Figuras 38 e 39).

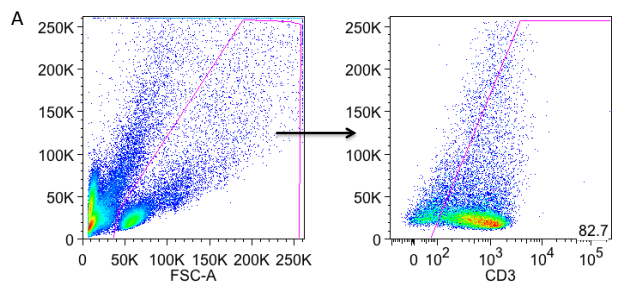

B
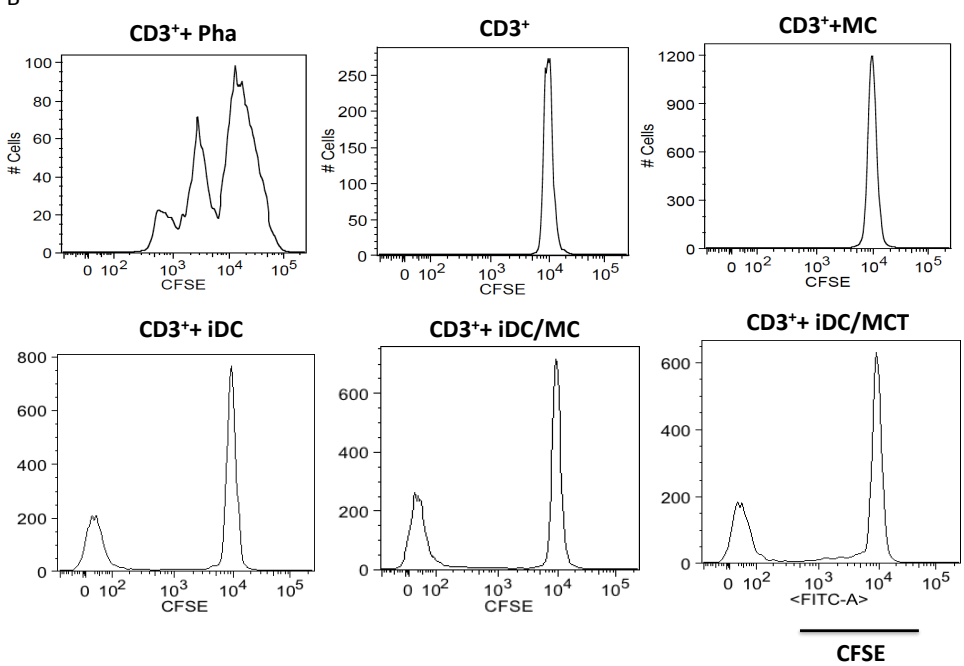

Figura 38. Capacidade estimuladora de células dendríticas imaturas co-cultivadas ou não com mastócitos. Representação em histograma da capacidade de proliferação, em que, na abscissa, está expresso o índice da fluorescência do CFSE. (A) demonstração da estratégia de análise, em que somente as células $\mathrm{CD}^{+}$foram escolhidas, nesta população, foi analisada a diluição do CFSE (B) esquerda para direita, grupo de estímulo positivo, sendo este feito com $1 \%$ volume/volume de fito-hemaglutinina-A (PHA), seguido pelo controle negativo (linfócitos cultivados apenas com meio de cultura), ao lado, linfócitos co-cultivados com MC. Abaixo, estão exibidos os grupos experimentais.

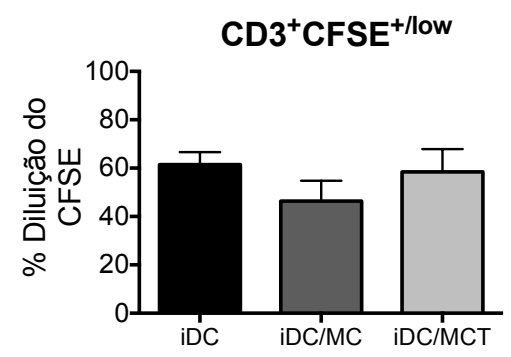

Figura 39. Representação gráfica do resultado da diluição do CFSE. Após cinco dias de co-cultura, as células foram removidas da placa e a diluição do corante CFSE das células $\mathrm{CD} 3+$ foi analisada por citometria de fluxo; PHA; $\mathrm{n}=8$; SE; $\mathrm{n}=8$; iDC; $\mathrm{n}=8$; MC $\mathrm{n}=3 ; \mathrm{MCT} ; \mathrm{n}=3$; iDC-MC; $\mathrm{n}=8$; iDC-MCT; $\mathrm{n}=5$. Para análise estatística, foi utilizado o teste de ANOVA, seguido pelo pós-teste de Tukey, sendo $\mathrm{p}<0,05\left(^{*}\right), \mathrm{p}<0,01\left(^{* *}\right)$ e $\mathrm{p}<0,001(* * *)$. 
Com o intuito de verificar se, de fato, o contato entre DCs e MC era necessário para a indução de um perfil tolerogênico das DCs, analisamos se as iDCs cultivadas com MCs no sistema transwell seria capaz de induzir a expressão de FoxP3. Conforme o esperado, uma vez que observamos aumento de moléculas associadas à maturação das DCs e o aumento das citocinas inflamatórias como IL-6 e TNF- $\alpha$. Notamos que as DCs provenientes do cultivo em transwell, apesar de demonstrarem um discreto aumento da expressão de FoxP3 em linfócitos $\mathrm{T}$ alogenênicos, este aumento não foi significativamente diferente dos obtidos em iDC sem estímulo (Figura 40).
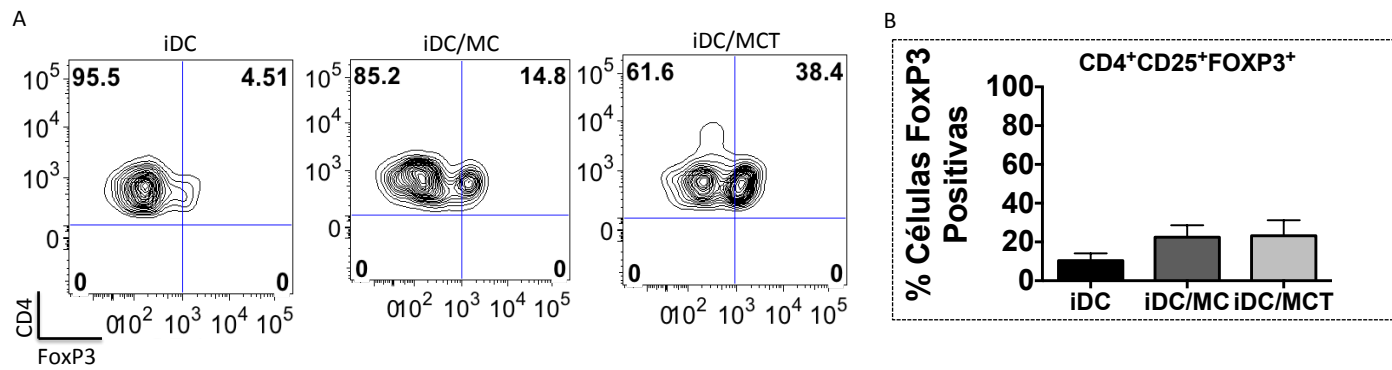

Figura 40. Avaliação da expressão de $\mathrm{FoxP3}$ nas células $\mathrm{CD}^{+} \mathrm{CD}^{+} \mathrm{CD}^{+} 5^{+}$quando estes linfócitos foram co-cultivados ou não com iDC previamente co-cultivas com mastócitos (iDC/MC) ou mastócitos sensibilizados (iDC/MCT). Linfócitos $T$ alogênicos foram isolados por seleção imunomagnética e cocultivados com iDC, iDC co-cultivadas com mastócito (iDC/MC) ou mastócitos sensibilizados com HCT116 (iDC/MCT), sendo ambas as co-culturas em sistema transwell (restrito aos mediadores produzidos por MC). Como estratégia de análise, primeiro, avaliamos a alteração do laser azul (time versus PE), e foram selecionados apenas o eventos que exibiram uma distribuição homogenia. Após, selecionamos as células por seu tamanho e sua granulosidade (FSC versus SSC), sendo escolhida a população referente aos linfócitos, depois, foram excluídos os eventos duplos, pelo gate FSC-A versus FSC-H. Apenas dentro dos eventos únicos, analisamos a frequência dos linfócitos duplo positivos para $\mathrm{CD} 4+$ e $\mathrm{CD} 25+$. Esta população foi, então, selecionada, e, assim, apenas nas células duplo positivas, analisamos a frequência de FoxP3. Está representada em (A). (B) Representação gráfica da frequência de FoxP3 dentre as células $\mathrm{CD}^{+} \mathrm{CD} 25^{+}$; (iDC; n=6; iDC/MC; $\mathrm{n}=5$; iDC/MCT; $\mathrm{n}=3$ ), para análise estatística, foi utilizado o teste de ANOVA, seguido pelo pós-teste de Tukey.

Interessantemente, ao compararmos a capacidade de indução da expressão de FoxP3 entre os co-cultivos, ou seja, com contato (iDC-MC) e sem contato (iDC/MC), observamos que iDC-MC possui uma maior função tolerogênica do que iDC/MC (Figura 38), inferido, até o presente momento, pela menor capacidade linfoestimuladora e maior indução de FoxP3 exercida por iDC-MC, mas não observada em iDC/MC; sugerindo, assim, que o contato entre MC e iDC pode modular as DCs para um viés "supressor". 

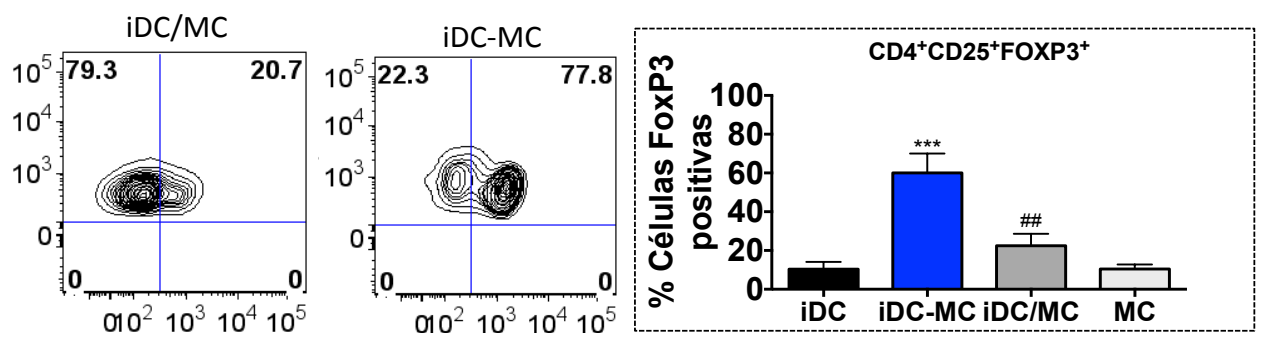

Figura 41. Comparação da frequência de células CD3+CD4+CD25+FoxP3+ entre iDC co-cultivadas com mastócito em monolayer (iDC-MC) contra co-cultivo em transwell (iDC/MC). Linfócitos T alogênicos foram isolados por seleção imunomagnética e co-cultivados com iDC, iDC co-cultivadas com mastócito em monolayer (iDC-MC) ou transwell (iDC/MC). Como estratégia de análise, primeiro, avaliamos a alteração do laser azul (time versus $\mathrm{PE}$ ), e foram selecionados apenas o eventos que exibiram uma distribuição homogenia. Após, selecionamos as células por seu tamanho e sua granulosidade (FSC versus SSC), sendo escolhida a população referente aos linfócitos, depois, foram excluídos os eventos duplos, pelo gate FSC-A versus FSC-H. Apenas dentro dos eventos únicos analisamos a frequência dos linfócitos duplo positivos para CD4+ e CD25+. Esta população foi então selecionada, e, assim, apenas nas células duplo positivas analisamos a frequência de FoxP3. Está representada em (A). (B) Representação gráfica da frequência de FoxP3 dentre as células $\mathrm{CD}^{+} \mathrm{CD} 25^{+}$; (iDC; $\mathrm{n}=6 ; \mathrm{iDC} / \mathrm{MC} ; \mathrm{n}=5 ; \mathrm{iDC} / \mathrm{MCT} ; \mathrm{n}=3$ ), para análise estatística, foi utilizado o teste de ANOVA, seguido pelo pós-teste de Tukey, sendo $\mathrm{p}<0,05(*), \mathrm{p}<0,01(* *)$ e $\mathrm{p}<0,001(* * *)$. Considerando * quando diferente de iDC e \# diferença entre os co-cultivos.

4.13 Avaliação da produção de IL-10 e TGF- $\beta$ dos linfócitos T co-cultivados com células dendríticas provenientes da co-cultura com mastócitos em um sistema transwell.

Com o intento de averiguar se o aumento de IL-10 e TGF- $\beta$ observado após co-cultivo de linfócitos T com iDC-MC e iDC-MCT era dependente de mediadores solúveis produzido por MCs ou MCT, mantivemos o protocolo de co-cultivo de MCs e DCs, no entanto, em sistema transwell, assim, após 2 dias de cultivo em transwell, tanto iDCs co-cultivadas com $\mathrm{MC}(\mathrm{iDC} / \mathrm{MC})$ quanto $\mathrm{MCT}(\mathrm{iDC} / \mathrm{MCT})$ foram retiradas da placa e plaqueadas na presença de linfócitos $\mathrm{T}$ alogenênicos (doadores não familiares) permaneceram em cultura por 5 dias. Transcorridos os dias de cultivo, os linfócitos foram removidos da cultura e marcados com anti-CD4; anti-CD25; anti-IL-10 e anti-TGF- $\beta$. Associado a não alteração da capacidade linfoestimuladora apresentada tanto por iDC/MC quanto iDC/MCT, observamos que estas não foram capazes de induzir aumento significativo de IL-10, apesar disso, nota-se, em iDC/MCT, uma tendência de aumento desta citocina, sugerindo que o cultivo prévio com tumor pode auxiliar na promoção de um ambiente imunossupressor via interação MC, DCs e linfócitos T. No entanto, ao unirmos este achado ao fato de que iDC/MCTs não foram capazes de este estimular a expressão de FoxP3 em linfócitos T, sugere-se que a polarização para um perfil Tr1 observado nos experimentos anteriores ocorre, principalmente, devido a contato célula-célula e não depende apenas de mediadores solúveis. 

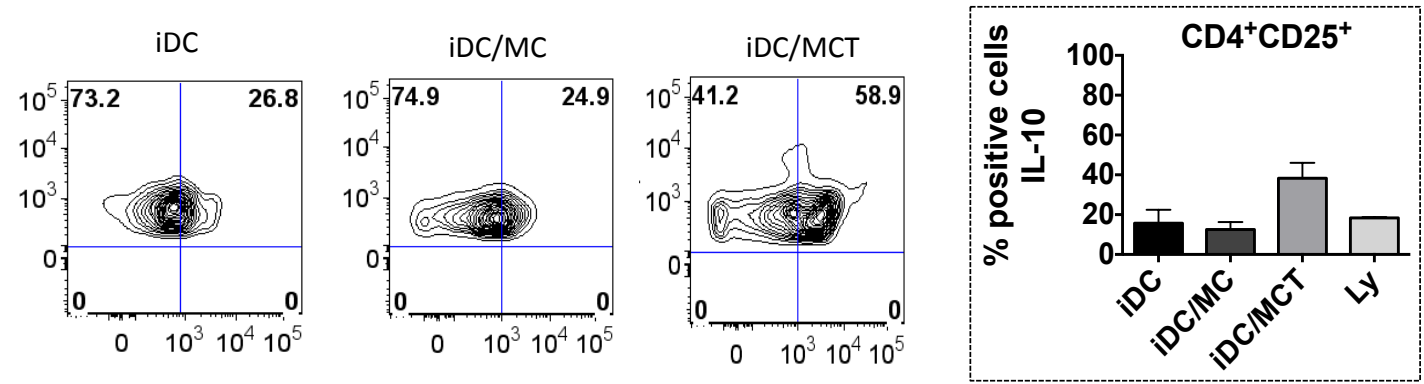

Figura 42. Avaliação da produção de IL-10 por linfócitos T co-cultivas com iDCs dos diferentes grupos experimentais. Estratégia de análise utilizada para avaliação da presença intracelular de IL-10, primeiramente, foram isolados os eventos duplos pelo gate de FSC-A versus FSC-H, após, as células com tamanho e granulosidade referentes a linfócitos foram selecionadas e, nesta população, foi avaliada a presença de células positivas para CD4 e CD25. Assim, apenas na população duplo-positiva, analisamos a frequência de células também positivas para IL-10, foi utilizado o isótopo-controle do anticorpo como parâmetro de marcação negativa e desenho do gate. Representação gráficas dos resultados obtidos, sendo utilizado o teste de ANOVA seguido pelo pós-teste Tukey, em que $*=p<0,05, * *=p<0,01, * * *=p<0,001$ e $* * * *=p<0,0001$. iDC, $n=3$; $\mathrm{iDC} / \mathrm{MC}, \mathrm{n}=3$; iDC/MCT, $\mathrm{n}=3$.

Ainda, observamos que os níveis de TGF- $\beta$ em linfócitos não estimulados estavam altos, impossibilitando, assim, a conclusão de que o co-cultivo tanto com iDC/MC quanto iDC/MCT desencadeiam o aumento da produção deste fator de crescimento (Figura 42). No entanto, observamos que linfócitos cultivados com iDCs sintetizaram menos TGF- $\beta$, por outro lado, ao compararmos iDC com as iDC/MCT, notamos que iDC/MCT estimularam maior produção de TGF- $\beta$ em linfócitos T; demonstrando, assim, a importância da interação tumoral com MCs para a promoção de um ambiente imunossupressor.
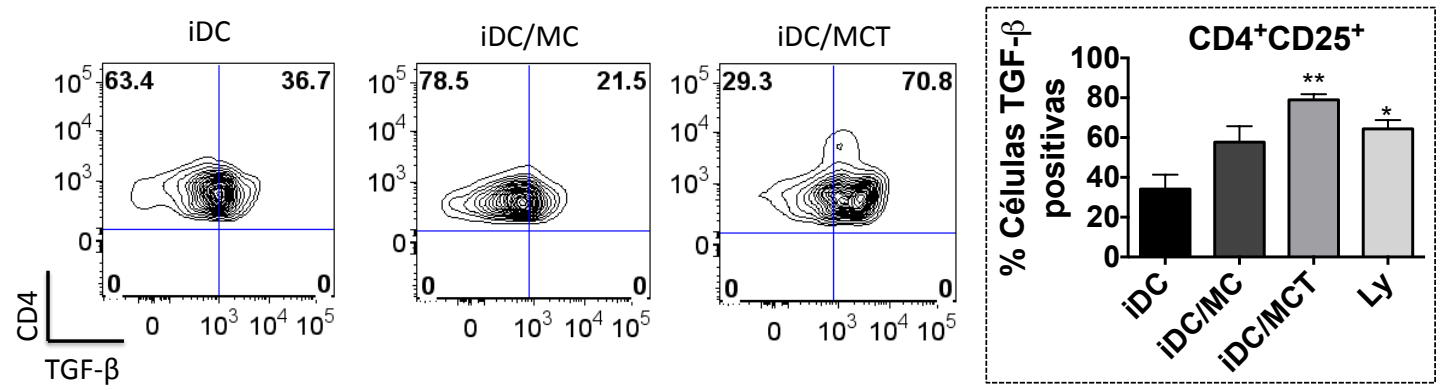

Figura 43. Avaliação da produção de TGF- $\beta$ por linfócitos $T$ co-cultivas com iDCs dos diferentes grupos experimentais. Estratégia de análise utilizada para avaliação da presença intracelular de TGF- $\beta$, primeiramente, foram isolados os eventos duplos pelo gate de FSC-A versus FSC-H, após, as células com tamanho e granulosidade referentes a linfócitos foram selecionadas e, nesta população, foi avaliada a presença de células positivas para CD4 e CD25. Assim, apenas na população duplo-positiva, analisamos a frequência de células também positivas para TGF- $\beta$, foi utilizado o isótopo-controle do anticorpo como parâmetro de marcação negativa e desenho do gate. Representação gráfica dos resultados obtidos, sendo utilizado o teste de ANOVA seguido pelo pós-teste Tukey, em que $*=p<0,05, * *=p<0,01, * * *=p<0,001$ e $* * * *=p<0,0001$. iDC, $n=3$; iDC/MC, n=3; iDC/MCT, n=3. 
4.14 Avaliação da capacidade supressora de linfócitos T CD4+CD25+ oriundos do co-cultivo com iDC previamente cultivadas com mastócito em um sistema transwell.

Embora nossos resultados anteriores demonstrassem que tanto iDC/MC quanto iDC/MCT não estimularam o aumento significativo da expressão de FoxP3 e IL-10 em linfócitos; nos perguntamos se o discreto aumento de ambos, principalmente em iDC/MCT, associado à manutenção da síntese de TGF- $\beta$ seriam suficientes para a supressão da proliferação de linfócitos T naïve. Para tal, mantivemos o protocolo de supressão, no entanto, com linfócitos $\mathrm{T} \mathrm{CD}^{+} \mathrm{CD} 25^{+}$provenientes do co-cultivo com iDC/MC ou iDC/MCT. Tal ensaio revelou que o aumento discreto de IL-10, e a alta produção de TGF- $\beta$ previamente observada não foram suficientes para a polarização de linfócitos $\mathrm{T}$ capazes de suprimir a proliferação de linfócitos $\mathrm{TCD}^{+}$naïve estimulados com PHA (Figura 44). Portanto, confirmando a hipótese de que a geração de tDCs descrita nos ensaios em monolayer não são dependentes, apenas, dos mediadores solúveis produzido/liberado por MCs.
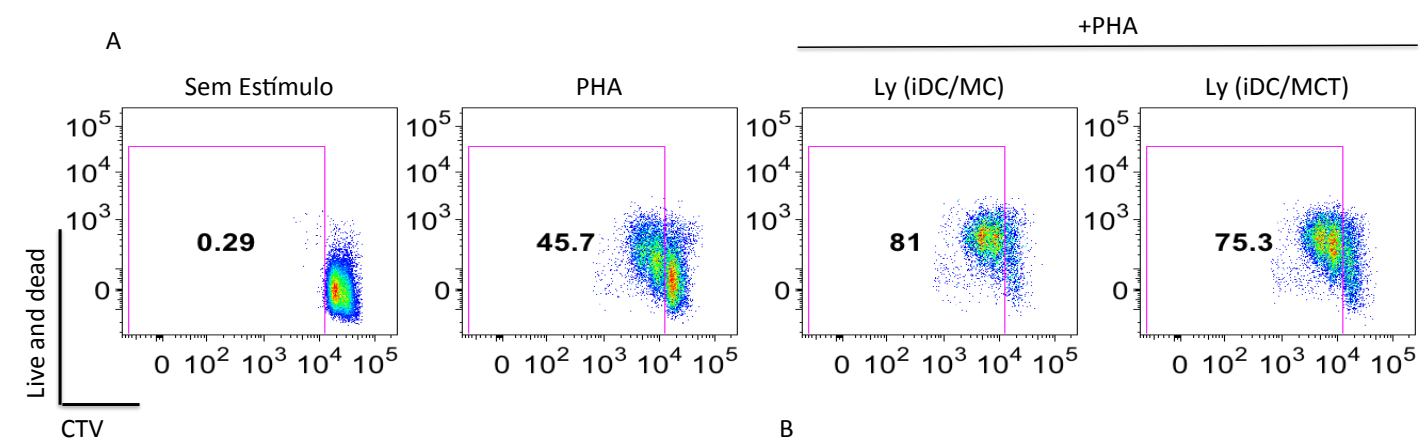

B

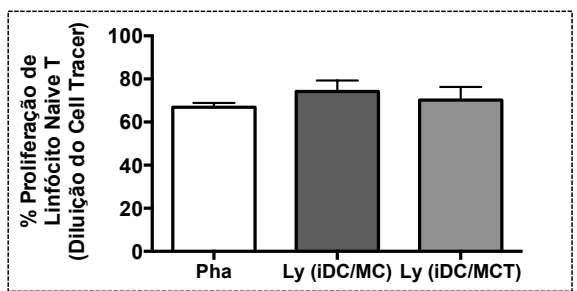

Figura 44. Avaliação da capacidade supressora dos linfócitos $\mathrm{CD}^{+} \mathrm{CD} 4^{+} \mathrm{CD}^{2} 5^{+}$oriundos do co-cultivo com mastócito em sistema transwell. Linfócitos $\mathrm{T}$ alogênicos foram co-cultivados por 5 dias com DCs provenientes do co-cultivo em transwell com MC (iDC/MC) ou MCT (iDC/MCT). Transcorrido o tempo de estímulo, os linfócitos $\mathrm{CD} 4{ }^{+} \mathrm{CD} 25^{+}$foram isolados por separação imunomagnéticas, estas foram, então, cocultivadas com Linfócitos $\mathrm{T} \mathrm{CD}^{+}$nä̈ve, também isolados por separação imunomagnética e corados com Cell Trace Violeta (CTV). Assim, ambos os linfócitos foram cultivados por três dias e estimulados com PHA (1\% volume/volume). Como estratégia de análise para definição de gates, consideramos, primeiramente, o tamanho e a granulosidade referente a linfócitos e células vivas (exclusão das células positivas para Live and dead). Assim, apenas dentro das células vivas (Live and dead') e $\mathrm{CTV}^{+}$analisamos a diluição do corante (A). Em (B), representação gráfica da supressão promovida pelos linfócitos CD3+CD4+CD25+ co-cultivadas com linfócitos T naïve e estimulados com PHA. Dados referentes quando respeitada a proporção de 1 linfócito $\mathrm{T}$ naïve para 1 linfócito $\mathrm{CD} 3+\mathrm{CD} 4+\mathrm{CD} 25+$ oriundo dos dois diferentes grupos experimentais. PHA, $\mathrm{n}=3$; iDC/MC, $\mathrm{n}=3$; iDC/MCT, $n=4$; para análise estatística, foi utilizado o teste de ANOVA, seguido pelo pós-teste de Tukey, sendo $\mathrm{p}<0,05(*), \mathrm{p}<0,01(* *)$ e $\mathrm{p}<0,001(* * *)$. 


\subsection{Avaliação da desgranulação de mastócitos após o co-cultivo em monolayer com células dendríticas.}

Embora nossos resultados sugiram a não dependência dos mediadores de MCs para a geração de tDCs, bem como, a polarização de linfócitos T para um viés supressor, vale advir que foi utilizado um sistema que não permitiu o contato celular (transwell), por assim o ser, até o presente momento, analisamos o efeito de mediadores solúveis produzidos por MCs, mas não se o contato de MCs e DCs poderia culminar na desgranulação de MCs propriamente dita. Logo, com o intuito de confirmar a necessidade da interação celular para a geração de tDCs, mas não de mediadores pré-formados produzidos por MCs, avaliamos se, durante o cocultivo em monolayer, ocorria a desgranulação de MCs.

Resultados indiretos de desgranulação nos indicaram que, durante o co-cultivo, não houve desgranulação, pois não observamos o aumento da expressão de CD107a na membrana de mastócito, indicando a não liberação de vesículas durante 24 horas de co-cultivo (Figura 45).

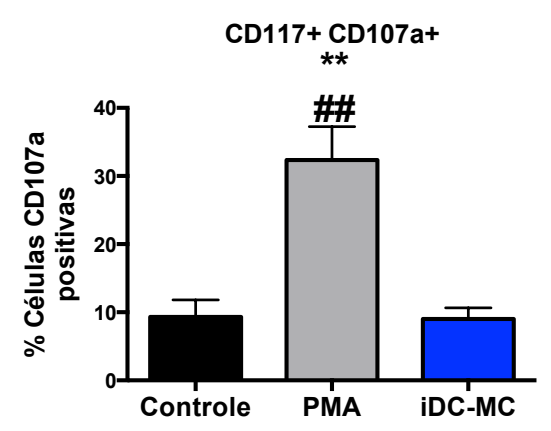

Figura 45. Avaliação da desgranulação de mastócitos após o co-cultivo em monolayer com células dendríticas. Com o intuito de averiguar se o co-cultivo entre MC e iDC poderia promover a desgranulação de mastócitos, as células de linhagem de mastocitoma humano HMC-1.1 foram utilizadas, assim, estas foram mantidas em cultura em IMDM-10 sem nenhum estímulo (controle), estimuladas com $100 \mathrm{ng} / \mathrm{uL}$ de PMA, sendo este o controle positivo de desgranulação, ou co-cultivadas com iDCs (iDC-MC), no meio de cultura, fora adicionado $1 \mathrm{uL} / \mathrm{mL}$ de Brefeldina $\mathrm{A}$ e $2 \mathrm{uL} / 10^{5}$ células do anticorpo CD107a conjugado com PE. Após 16 horas, a frequência de células $\mathrm{CD} 117^{+} \mathrm{CD} 107 \mathrm{a}^{+}$foi analisada por citometria de fluxo. Controle, $\mathrm{n}=4$; PMA, n=5; iDC$\mathrm{MC}, \mathrm{n}=4$. Para análise estatística, foi utilizado ANOVA, seguido pelo pós-teste de Tukey, $\mathrm{p}<0,01(* *),{ }^{*}$ quando diferente de iDC e \# iDC-MC.

Contudo, a expressão de CD107a de membrana é uma medida indireta de desgranulação celular, assim, se fez necessária a confirmação deste fenômeno por outros experimentos; considerando, então, a via de transdução do sinal necessária para a desgranulação de MCs. Assim, levando em conta o processo de desgranulação, em que, de maneira geral, após a dimerização do FCعRIa, podem participam três vias intracelulares 
distintas, sendo a primeira a ativação transiente de Lyn (proteína tirosina quinase, PTK), que, por sua vez, culmina na fosforilação de ITAMs (sequências de ativação baseadas na tirosina do imunorreceptor), paralelamente à ativação da Lyn, a dimerização de FCERI $\alpha$ também resulta na ativação de outra PTK, a Syk. Esta, por sua vez, se liga aos ITAMs fosforilados do receptor resultando na fosforilação da fosfolipase $\mathrm{C} \gamma$ (PLC $\gamma$ ). Nestas condições, a PLC $\gamma$ hidrolisa fosfatidilinositol 4,5 bifosfato $\left(\mathrm{PI}_{4}, 5 \mathrm{P}_{2}\right)$, gerando, assim, inositol-1,4,5 trifosfato $\left(\mathrm{IP}_{3}\right)$ e diacilglicerol (DAG), sendo que o primeiro é responsável pela liberação de $\mathrm{Ca}^{2+}$ dos reservatórios intracelulares e o segundo ativa a proteína quinase $\mathrm{C}(\mathrm{PKC})$. Ainda, a dimerização do FCeRI $\alpha$ resulta na ativação da quinase Fyn, esta, de modo geral, coopera para o aumento de $\mathrm{Ca}^{2+}$ intracelular. Paralelamente à esfingosina quinase (SK) citosólica, também é recrutada para a membrana plasmática após estímulo dos MCs. A SK, por sua vez, resulta na síntese de esfingosina-1-fosfato (S1P), responsável, também, pelo aumento do influxo de $\mathrm{Ca}^{2+}$. Portanto, dentro outros fatores, acredita-se que as etapas tardias das vias de desgranulação de MCs resulta no aumento do $\mathrm{Ca}^{2+}$ intracelular (Pearce, 1985). Sendo assim, células HMC-1.1 foram coradas com Fluo-4AM (Life Technologies ${ }^{\circledR}$ ) e desafiadas com meio de cultura (controle de negativo, HMC-1.1), ionomicina, controle positivo do influxo de $\mathrm{Ca}^{2+}$ (HMC-1.1+ION) ou iDCs. Corroborando a baixa expressão de CD107a, nossos dados revelaram que o co-cultivo com iDCs não resultou no aumento do $\mathrm{Ca}^{2+}$ intracelular, independente da concentração de iDCs (Figura 46), confirmando, assim, que a interação MCs e iDCs não resulta na desgranulação de MCs. 


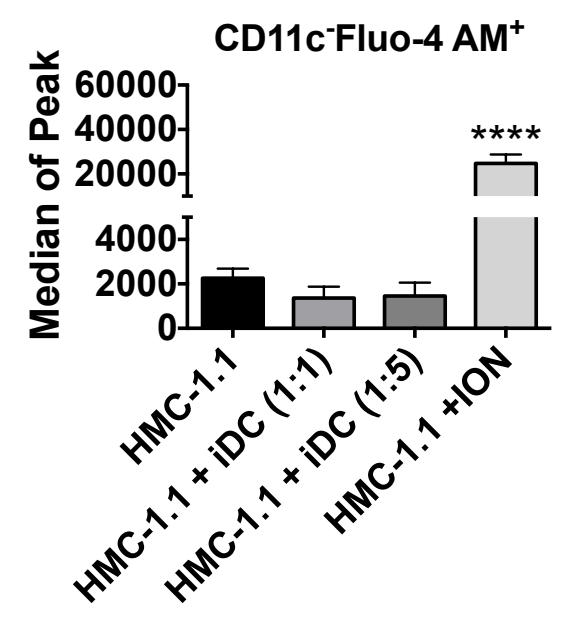

Figura 46. Avaliação da desgranulação de mastócitos após o co-cultivo em monolayer com células dendríticas. Considerando o influxo de cálcio uma etapa necessária para a desgranulação de mastócitos, células da linhagem de mastocitoma humano (HMC-1.1) foram marcadas com o corantes Fluo-4 AM e mantidas em tampão de $\mathrm{Ca}^{2+}(1 \mathrm{X})$, estas foram, então, analisadas em um citômetro FACSCanto $\mathrm{BD}^{\odot}$, assim, foram selecionadas as $\mathrm{CD} 11 \mathrm{c}^{-}$Fluo-4AM(FITC) ${ }^{+}$, após 60 segundos de aquisição de eventos, as células foram desafiadas com iDC na proporção de 1:1 (HMC-1.1 + iDC (1:1)) ou 1:5 (HMC-1.1 + iDC (1:5)), respectivamente. Como controle de desgranulação positivo, as células HMC-1.1 foram desafiadas com 200ng/mL de ionomicina (ION), após, foram adquiridos 240 segundos. HMC-1.1, n=8; HMC-1.1 + iDC (1:1), $\mathrm{n}=3$; HMC-1.1 + iDC (1:5), n=3; HMC-1.1 + ION, n=3. Para análise estatística, foi utilizado ANOVA, seguido pelo pós-teste de Tukey, $\mathrm{p}<0,0001(* * * *)$.

4.16 Avaliação da dependência do contato para a polarização de DCs tolerogênicas.

A compilação dos resultados apresentados, até o momento, indica a dependência do contato para a geração tDCs, assim, com o intuito de confirmar tal dependência, modificamos a proporção de $1 \mathrm{MC}$ para $10 \mathrm{iDCs}$.

Com isso, verificamos a dependência da interação para a geração de tDCs, pois, ao aumentarmos a quantidade de iDCs, notamos o aumento de HLA-DR, CD80 e CD209, associado à diminuição de PD-L1 e CCR7 (Figura 47); assim, demonstrando que o contato parece ser fundamental para a geração de tDCs. 

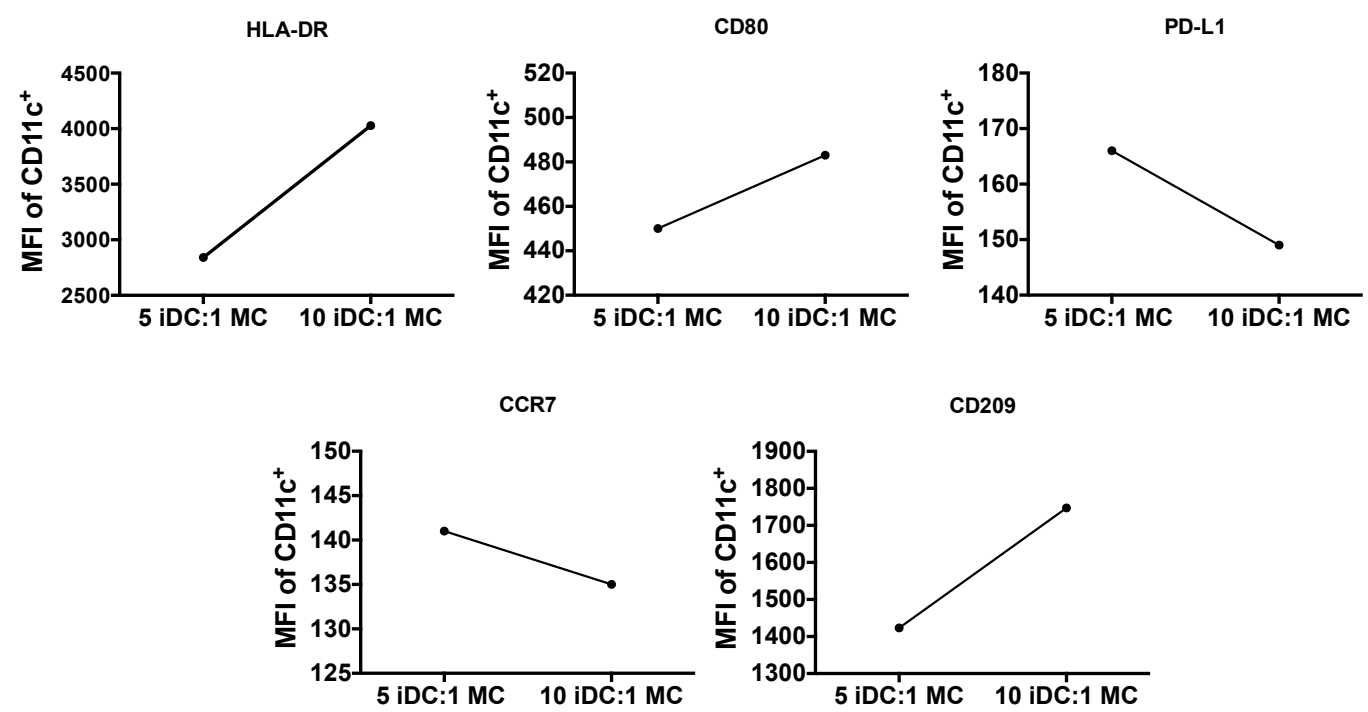

Figura 47. Confirmação da dependência do contato celular para a geração de tDCs. MCs diferenciados in vitro foram co-cultivados com iDCs autólogas em diferentes proporções, assim, podemos notar que, com o aumento de iDCs, mas mantendo o número de $\mathrm{MCs}$, tem-se o aumento de moléculas relacionadas à ativação de linfócitos T, ao passo que observamos a diminuição de PD-L1 e CCR7, em relação ao grupo 5 iDCs: 1 MC, n=1.

4.17 Avaliação do PD-1 expresso em mastócito como responsável para a indução de DCs tolerogênicas.

Como a interação célula-célula parece ser necessária para a indução de tDCs, constituímos a hipótese de que uma molécula de superfície presente em MCs poderia ser responsável pela geração de tDC. Assim, ao considerar o aumento de PD-L1 nas iDC-MC e iDC-MCT, bem como sua diminuição em iDC/MC e iDC/MCT, nos questionamos se a ligação de PD-L1 com seu ligante PD-1 poderia resultar na geração de tDCs.

Assim, inicialmente, avaliamos a expressão de PD-1 nos MCs derivados in vitro e na linhagem HMC-1.1. Conforme apresentado na Figura 48, ambas as células expressam PD-1 em sua membrana. De maneira similar, confirmamos a expressão de PD-1 nas células HMC1.1 por microscopia confocal (Figura 49). 
A

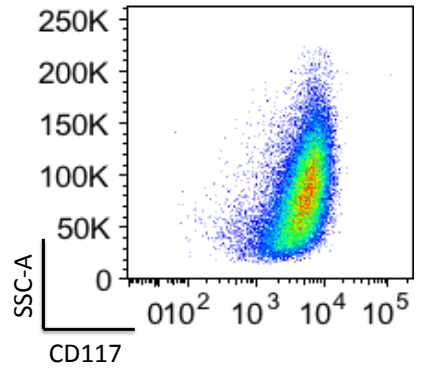

B

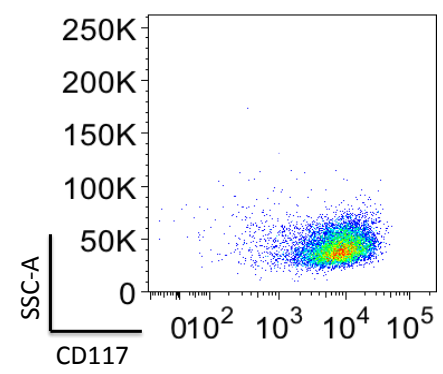

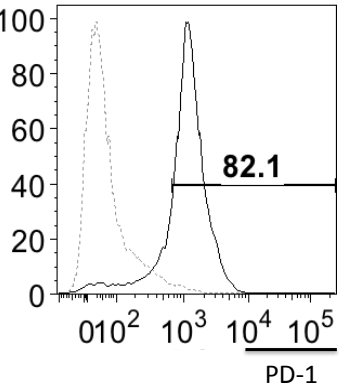

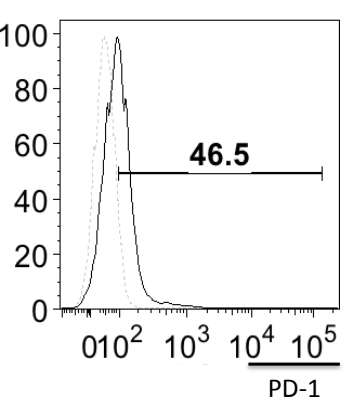

C

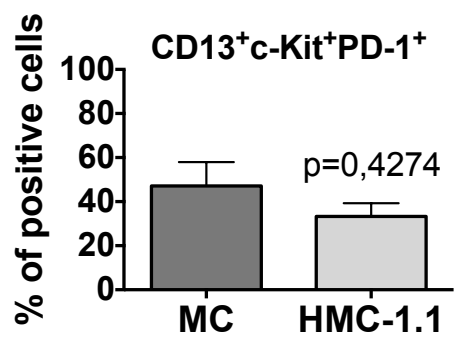

Figura 48. Avaliação da expressão de PD-1 (CD279) na membrana de mastócitos diferenciados in vitro e da linhagem de mastocitoma humano HMC-1.1. Como estratégia de análise, primeiramente, foram selecionados apenas os eventos únicos pelo gate de FSC-A versus FSC-H, então, apenas as células com tamanho e granulosidade referentes aos MC foram selecionadas (FSC-A versus SSC-A), nesta população, foram excluídas as células mortas (Live and dead ${ }^{+}$) e apenas nas células vivas analisamos a frequência de células CD117 $7^{+}$, correspondente a mais de $95 \%$ dos eventos, assim, analisamos a expressão de PD-1 em tanto em MCs (A) quanto em HMC-1.1 (B). (C) Representação gráfica dos dados obtidos. MC, n=6; HMC-1.1, n=3. Para análise estatística, foi utilizado o teste T de Student não paramétrico.
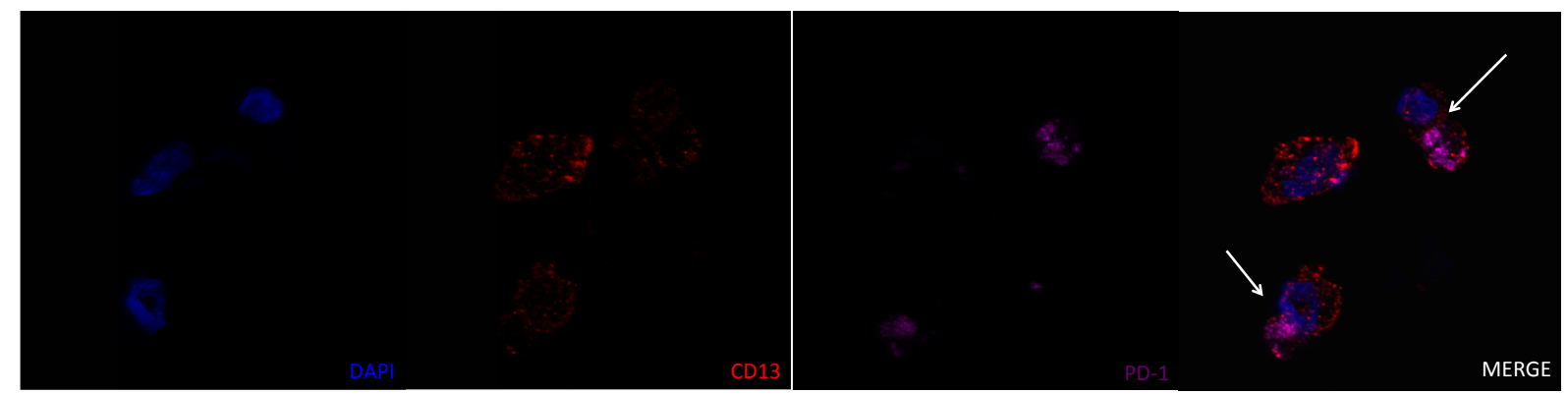

Figura 49. Avaliação da expressão de PD-1 (CD279) na membrana de HMC-1.1. Células de mastocitoma (HMC-1.1) foram coradas com anti-CD13 conjugado com PE, anti-PD-1 conjugado ao APC e, após marcação, as células foram fixadas e coradas com DAPI.

4.18 Quantificação relativa da expressão do gene IDO1 pelas células dendríticas co-cultivadas com linhagens de mastocitoma.

Sabendo que o sobrenadante de MC foi capaz de aumentar a produção de IL-10 (Figura 37) e esta não foi suficientemente capaz de polarizar as DCs para um perfil tolerogênico; perguntamo-nos se as células iDC-MC poderiam ser mais competentes quanto à produção de indoleamina-2,3, deoxigenase (IDO), uma vez que esta enzima possui grande importância tanto para a geração de tDCs quanto para a indução de linfócitos T reguladores. 
Assim, com o fito de avaliar se iDC-MC, de fato, sintetizava maiores quantidade de IDO, primeiramente, avaliamos a expressão relativa do gene IDO1 em relação a um gene constitutivo $\beta$-actina. Assim, após 16 horas de co-cultivo, o período de estimulação foi baseado nos estudos de Taylor et al. (Taylor e Feng, 1991), as células foram removidas da cultura e separadas por coluna imunomagnética em que apenas as células CD11 $\mathrm{c}^{+}$tiveram seu RNA extraído, quantificado e utilizado como template do cDNA. Conforme esperado, notamos que, após o co-cultivo com HMC-1.1, as iDCs demonstraram amplificação do gene IDOI.

Curiosamente, no entanto, quando as HMC-1.1 foram previamente tratadas com antiPD-1, notamos a não amplificação do gene (Figura 50 e 51).

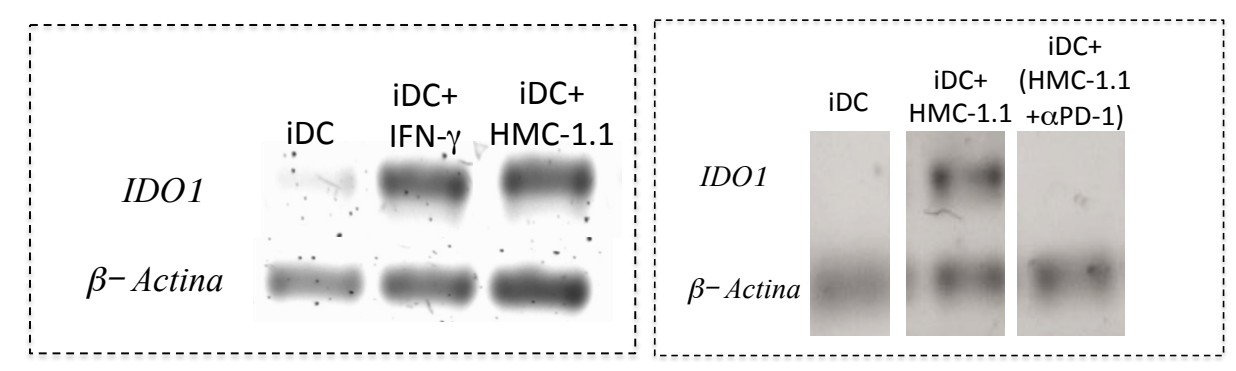

Figura 50. Análise da expressão de IDO1 pelas células dendríticas co-cultivas com HMC-1.1. À esquerda, exibimos foto demonstrativa do gel de agarose $0,6 \%$, em que foram aplicados o produto da qPCR de amostras referentes ao controle negativo (iDC), controle positivos (iDC tratadas com IFN- $\gamma$ 0,1 mg/mL) e grupo experimental (iDC co-cultivadas com HMC-1.1 por 16 horas). Assim, podemos observar que as amostras positivas e grupo experimental demonstraram amplificação do gene $I D O 1$, responsável pela transcrição da enzima indoleamina-2,3, deoxigenase. Ao lado, exibimos foto demonstrativa do gel de agarose $0,6 \%$, em que foram aplicados o produto da qPCR de amostras referentes ao controle negativo (iDC), e iDC co-cultivadas com HMC-1.1 (iDC + HMC-1.1) ou iDC cultivadas com HMC-1.1 previamente tratados com anti-PD1 ((iDC + (HMC-1.1+ $\alpha$ PD-1)), assim, observamos que o bloqueio de PD-1 resulta no desaparecimento da banda referente à amplificação do gene IDOI. 

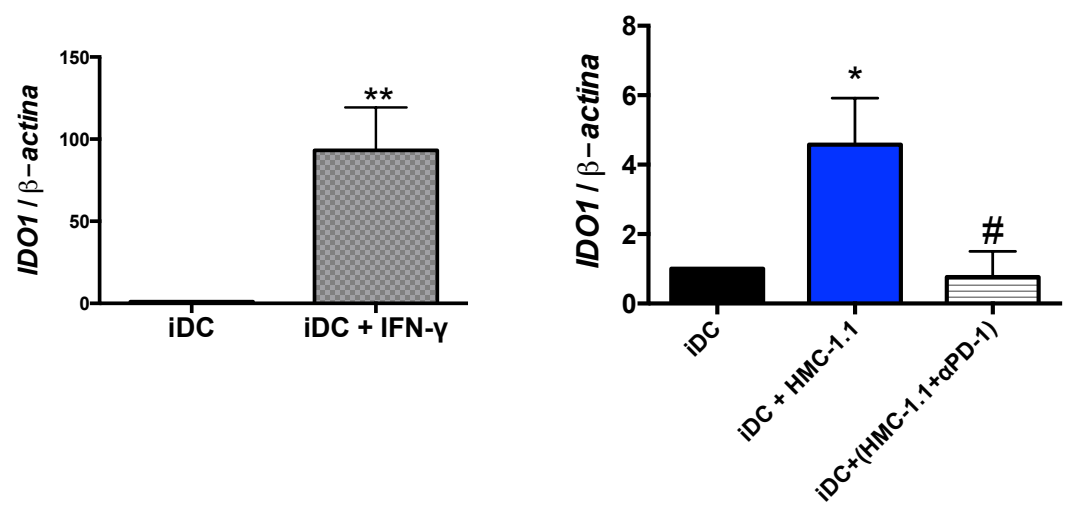

Figura 51. Representação gráfica da análise da expressão de IDO1 pelas células dendríticas co-cultivas com HMC-1.1. À esquerda, exibimos a expressão relativa de IDO1 em iDC e iDC estimuladas com $0,1 \mu \mathrm{g} / \mu \mathrm{L}$ (controle positivo), ao lado, exibimos o gráfico referente à expressão relativa de IDO1 em iDC, iDC cocultivadas com HMC-1.1 (iDC + HMC-1.1) e iDC co-cultivadas com HMC-1.1 tratado com anti-PD-1 (iDC+(HMC-1.1+ $\alpha \mathrm{PD}-1)$. Para análise estatística, foi utilizado ANOVA, seguido pelo pós-teste de Tukey, $\mathrm{p}<0,05(* / \#)$, * se diferente de iDC e \# se diferente de iDC+ HMC-1.1. iDC, $\mathrm{n}=6$; iDC + HMC-1.1, $\mathrm{n}=6$; $\mathrm{iDC}+(\mathrm{HMC}-1.1+\alpha \mathrm{PD}-1, \mathrm{n}=4$.

Em outro momento, verificamos se o aumento da expressão de IDOI também repercutiu no aumento da síntese de IDO, conforme o esperado, após o tratamento das iDCs com IFN- $\gamma$ - controle positivo para a produção desta enzima -, observamos um aumento significativo da produção de IDO, corroborando com o aumento do gene IDOI. Ainda, conforme esperado, nota-se, também, que iDCs co-cultivadas com células HMC-1.1 expressavam uma alta produção desta enzima (Figura 52A e B).

Além disso, se considerarmos que o bloqueio de PD-1 expresso pelas células HMC1.1 resultou na diminuição do gene $I D O 1$, nos questionamos se o bloqueio de PD-1 em HMC1.1, bem como seus ligantes expressos pelas DCs (PD-L1 e PD-L2) poderiam resultar na diminuição da produção da IDO pelas células $\mathrm{CD} 11 \mathrm{c}^{+}$. Assim, corroborando com o resultado da expressão genética, notamos uma diminuição significativa da produção desta enzima quando HMC-1.1 foram tratadas com anti-PD-1; No entanto, ainda não sabemos ao certo qual ligante seria o principal responsável pela geração de DCs produtoras de IDO, uma vez que, ao bloquearmos tanto PD-L1 quanto PD-L2 nas iDCs, notamos a diminuição da produção de IDO. Todavia, vale ressaltar que a interação com PD-1/PD-L2 parece ser mais comprometida com a geração de iDCs produtoras de IDO do que a interação PD-1/PD-L1 (Figura 52C). 


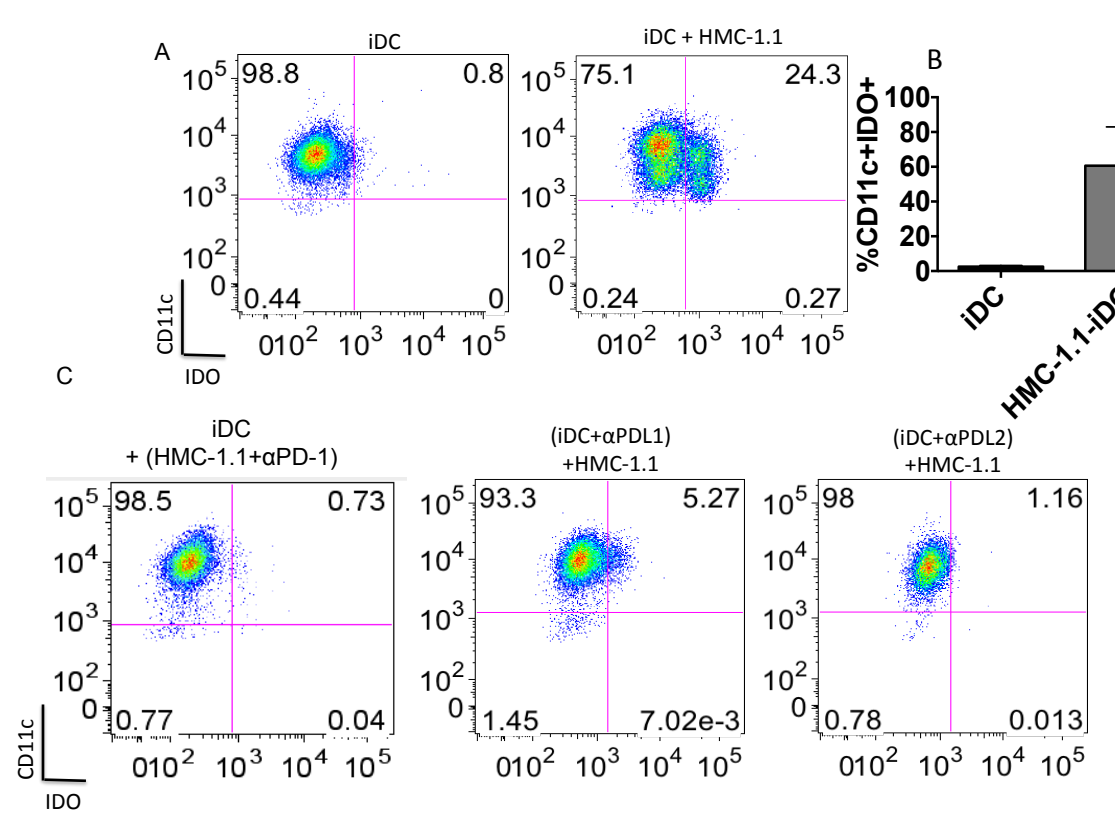

D

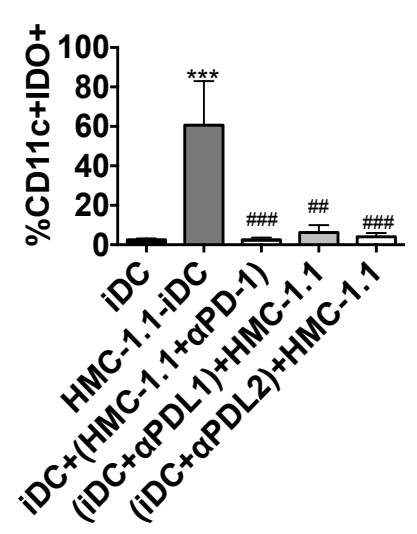

Figura 52. Avaliação da produção de IDO nas iDCs após co-cultivo com HMC-1.1. Com o intuito de averiguar o aumento da produção de IDO iDCs, foram co-cultivas com HMC-1.1 por 16h. Como estratégia de análise, primeiramente, selecionamos os eventos únicos (FSC-A versus FSC-H), após, foram excluídas as células mortas (exclusão das células Live and dead ${ }^{+}$) e, assim, apenas nas células vivas, analisamos a frequência de CD11c+ (DCs) e CD117 (MC), portanto, para a análise da presença de IDO, analisamos apenas as células CD11c+. Em (A), podemos observar a presença de IDO em iDC (à esquerda) e, à direita, após co-cultivo com HMC-1.1. (B) Representação gráfica dos dados obtidos. (C) Análise da produção de IDO em células CD11c+ após co-cultivo com HMC-1.1 previamente tratados com anti-PD-1 (iDC + (HMC-1.1+ $\alpha$ PD-1), iDCs bloqueadas com anti-PDL1 ((iDC $+\alpha$ PDL1)+HMC-1.1) ou bloqueadas com anti-PDL2 ((iDC $+\alpha$ PDL2)+HMC1.1). (D) Representação gráfica dos resultados obtidos. Para análise estatística, foi utilizado ANOVA, seguido pelo pós-teste de Tukey, $\mathrm{p}<0,05(* / \#)$, * se diferente de iDC e \# se diferente de iDC+ HMC-1.1. iDC, $\mathrm{n}=5$; iDC $+($ HMC-1.1 $+\alpha$ PD-1), (iDC $+\alpha$ PDL1) + HMC-1.1, $\mathrm{n}=5 ;(\mathrm{iDC}+\alpha \mathrm{PDL} 2)+\mathrm{HMC}-1.1, \mathrm{n}=5$.

Além disso, embora as células HMC-1.1 não sejam potentes produtoras de histamina (Guhl, Babina, Neou, Zuberbier, Artuc, 2010), com o intuito de excluir a participação desta, como responsável pelo fenômeno observado, antes do co-cultivo com HMC-1.1, as iDCs foram tratadas com $50 \mu \mathrm{M}$ de cloridrato de olopatadina (bloqueador do receptor 1 de histmanina, anti-H1) ou $50 \mu \mathrm{M}$ de cimetina (bloqueador do receptor 2 de histamina, anti-H2) (Zhai et al., 2013). Como o bloqueio dos receptores histaminérgicos não alterou significativamente a expressão gênica de IDOI nem a produção de IDO, concluímos que a histamina, de fato, não parece exercer um papel importante na geração de células

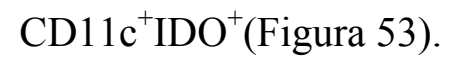



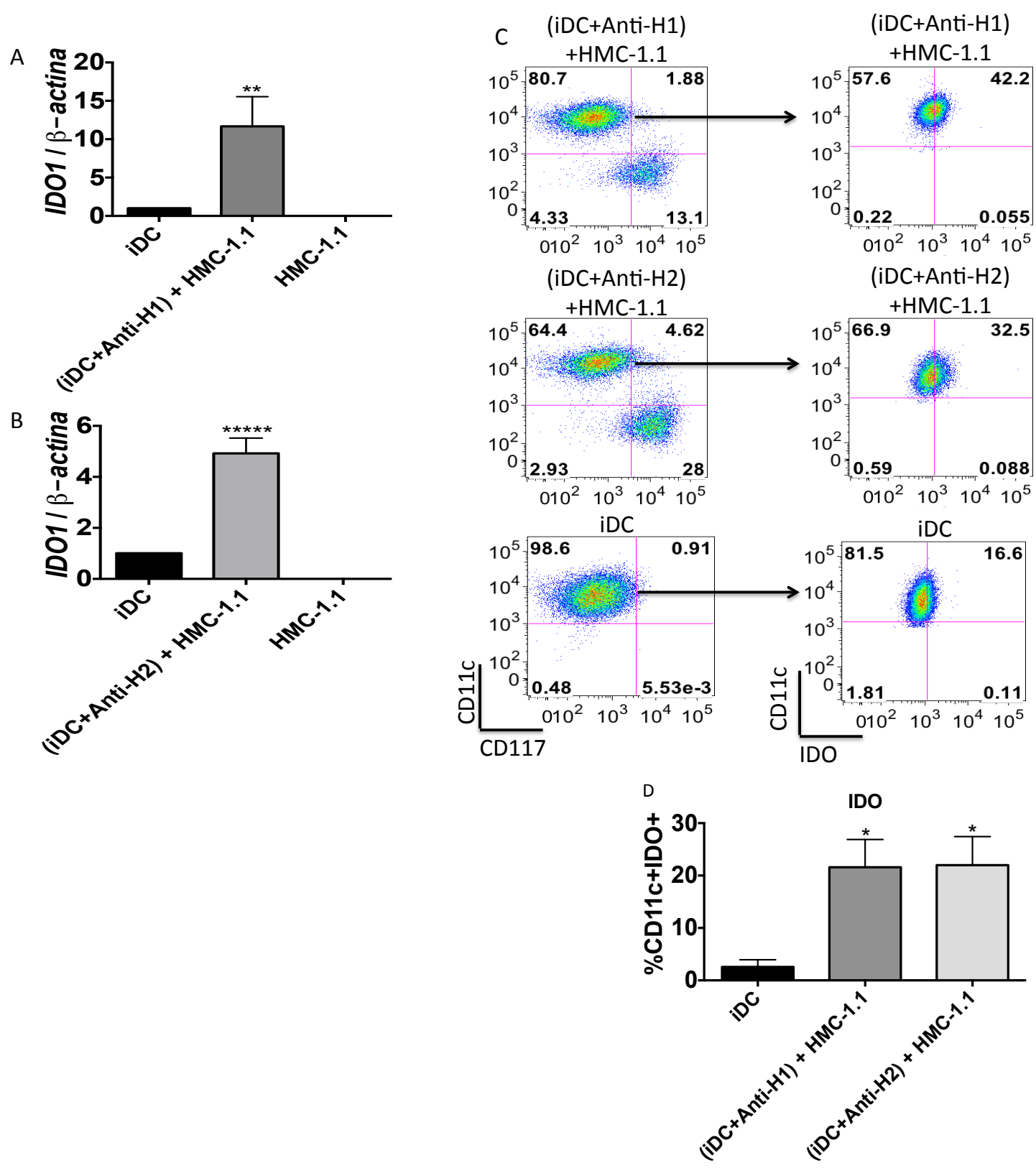

Figura 53. Avaliação da produção de IDO nas iDCs após co-cultivo com HMC-1.1 quando bloqueado receptor histaminérgico 1 e 2 nas iDCs. Com o intuito de averiguar a participação de histamina para a produção de IDO, células iDCs foram tratadas com $50 \mu \mathrm{M}$ de cloridrato de olopatadina (iDC+Anti-H1) ou cimetidina (iDC+Anti-H2) por 1 hora. Então, foram co-cultivadas com células HMC-1.1, respeitada a proporção de 5 iDCs: 1 HMC-1.1, tal co-cultura foi mantida por 16 horas. Em (A), demonstramos a amplificação do gene IDO1 nas células $\mathrm{CD} 11 \mathrm{c}^{+}$após o tratamento com Anti-H1, também quando tratadas com Anti-H2 (B). iDC, $\mathrm{n}=6$; $(\mathrm{iDC}+$ Anti-H1) $+\mathrm{HMC}-1.1, \mathrm{n}=3$; (iDC + Anti-H2) $+\mathrm{HMC}-1.1, \mathrm{n}=3$. A análise da produção de IDO foi feita por citometria de fluxo, como estratégia de análise, primeiramente, selecionamos os eventos únicos (FSC-A versus FSC-H), após, foram excluídas as células mortas (exclusão das células Live and dead ${ }^{+}$) e, assim, apenas nas células vivas analisamos a frequência de $\mathrm{CD} 11 \mathrm{c}+(\mathrm{DCs})$. Em (C), podemos observar a presença de IDO pelas células $\mathrm{CD} 11 \mathrm{c}^{+}$tratadas com o anti-histamínico. (D) Representação gráfica dos resultados obtidos iDC, $\mathrm{n}=4$; $(\mathrm{iDC}+$ Anti-H1) $+\mathrm{HMC}-1.1, \mathrm{n}=5 ;(\mathrm{iDC}+$ Anti-H2) $+\mathrm{HMC}-1.1, \mathrm{n}=5$. Para análise estatística, foi utilizado ANOVA, seguido pelo pós-teste de Tukey, $\mathrm{p}<0,05(*), \mathrm{p}<0,01(* *)$ e $\mathrm{p}<0,00001(* * * *)$. 
4.19 Avaliação da produção de TGF- $\beta$ de mastócitos após co-cultura com células dendríticas.

Em outro momento do estudo, avaliamos se a interação de PD-1 com seus ligantes, PD-L1 e PD-L2, poderia induzir a produção de citocinas anti-inflamatórias pelos MCs, colaborando, assim, para a manutenção do estado imunossupressor observado em tumores, assim como na manutenção das DCs em um estado imaturo ou mesmo tolerogênico. Assim, embora não tenhamos observado diferenças quanto à produção de IL-10 pelos MCs (dados não apresentados), corroborando com os achados anteriores, nota-se que as células HMC-1.1 tratadas com anti-PD-1 produziram menores quantidades de TGF- $\beta$ comparadas com HMC1.1 não bloqueadas e cultivadas com iDCs (Figura 54); indicando que a interação PD-1 e seus ligantes, provavelmente, seja bilateral, e capaz de induzir tanto as DCs quanto os MCs para um viés de tolerância.

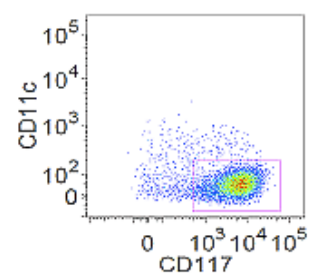

HMC $1.1+$ iDC

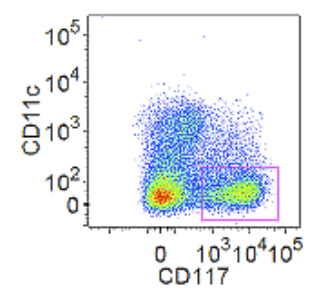

(aPD1-HMC-1.1)

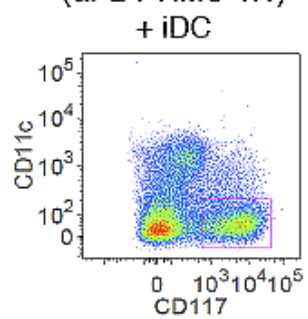

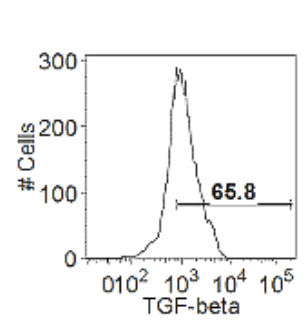
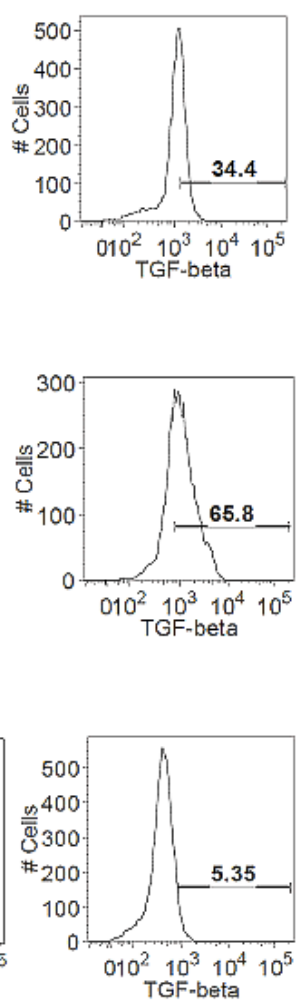

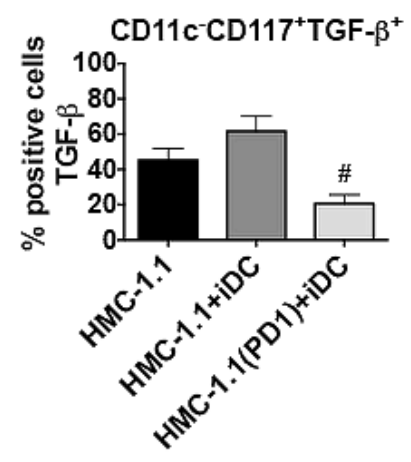

Figura 54. Tratamento de HMC-1.1 com anti-PD-1 resulta na menor produção de TGF- $\beta$. Com o intuito de averiguar o efeito do bloqueio de PD-1 na função de mastócitos, células HMC-1.1 foram utilizadas como modelo, assim, estas foram tratadas (HMC-1.1(PD1)+iDC) ou não com anti-PD-1 e, então, co-cultivadas com iDC (HMC-1.1+iDC) por 16 horas e tratadas com Brefeldina-A por 6 horas. Assim, a frequência de células $\mathrm{CD} 117^{+}$TGF- $\beta^{+}$foram avaliadas por citometria de fluxo. HMC-1.1, $\mathrm{n}=5$; HMC-1.1+iDC, $\mathrm{n}=5$; HMC1.1(PD1)+iDC,n=3. Para análise estatística, foi utilizado o teste de ANOVA seguido por Tukey, sendo $(\#)=\mathrm{p}<0,05$ e diferente de iDC+HMC-1.1.

Ainda, esse achado poderia nos indicar que a produção de IDO pelas células CD11 ${ }^{+}$ seria resultado do aumento de TGF- $\beta$ presente no ambiente, no entanto, com o objetivo de 
avaliar a participação da produção de TGF- $\beta$, antes do co-cultivo com células HMC-1.1, as DCs foram tratadas com anti-CD105 (receptor de TGF- $\beta$ ); Assim, notamos que o bloqueio do receptor deste fator de crescimento não alterou a capacidade de produção da IDO pelas

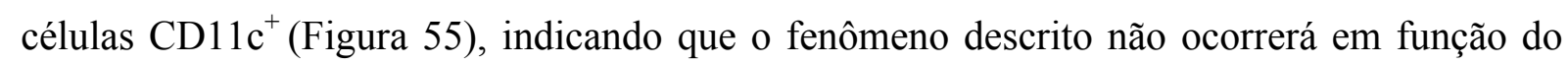
aumento de TGF- $\beta$.
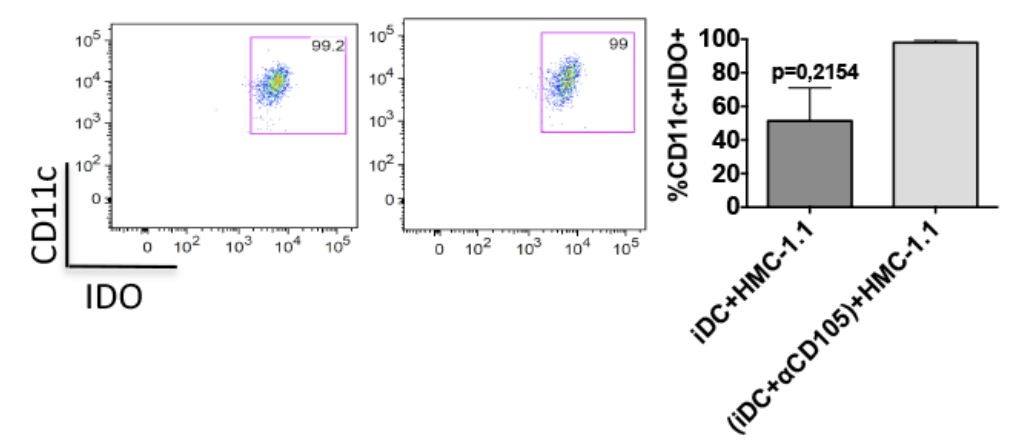

Figura 55. Bloqueio do receptor de TGF- $\beta$ expresso pelas DCs, não altera a produção de IDO. Com o intuito de averiguar o efeito a possível importância de TGF- $\beta$ para a produção de IDO, para tal, iDCs foram tratadas com anti-CD105 (TGF- $\beta$-R) e co-cultivadas com células HMC-1.1. iDC, $\mathrm{n}=3$; (iDC+ $\alpha \mathrm{CD} 105)+\mathrm{HMC}-$ $1.1, \mathrm{n}=3$. Para a análise, foi utilizado teste T-Student.

4.20 Tratamento prévio das células HMC-1.1 com anti-PD-1 impede a geração de DCs tolerogênicas.

Nesta etapa do estudo, averiguamos se o tratamento de HMC-1.1 com anti-PD-1 poderia reverter o perfil tolerogênico das DCs. Assim, após 16 horas co-cultura, avaliamos a capacidade de produção de TNF- $\alpha$ das células CD11 ${ }^{+}$. Observamos, assim, que, quando HMC-1.1 foram previamente tratadas com anti-PD-1 e co-cultivadas com iDCs, estas DCs exibiram um aumento na capacidade de produção de TNF- $\alpha$, fenômeno este não observado na co-cultura com células HMC-1.1 não bloqueadas (PD-1) (Figura 56). 


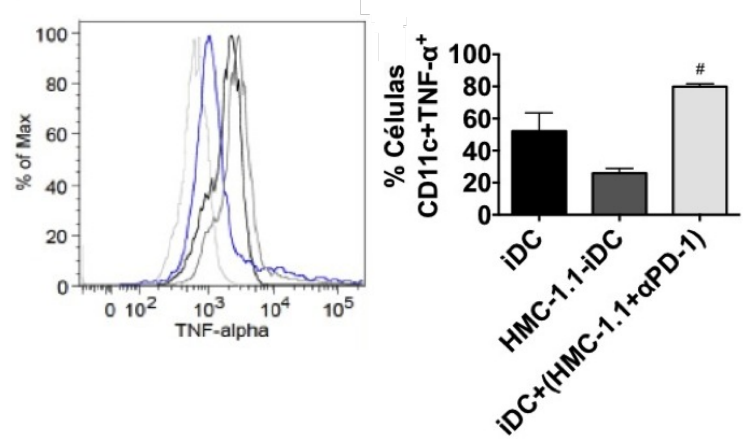

Figura 56. Avaliação da produção de TNF-a em iDCs. Com o intuito de averiguar o efeito do bloqueio de PD-1 na função das DCs, células HMC-1.1 foram tratadas com anti-PD-1 (iDC + ( $\alpha$ PD-1+HMC-1.1) ou não (iDC-HMC-1.1), e, então, co-cultivadas por 16 horas e tratadas com Brefeldina-A por 15 horas. Assim, a frequência de células CD11 $\mathrm{c}^{+} \mathrm{TNF}-\alpha^{+}$foi avaliada por citometria de fluxo. iDC, $\mathrm{n}=5$; HMC-1.1-iDC, $\mathrm{n}=3$; iDC + ( $\alpha$ PD-1+HMC-1.1), $n=2$. Para análise estatística, foi utilizado o teste de ANOVA seguido por Tukey, sendo $(\#)=p<0,05$ e diferente de iDC-HMC-1.1.

Como observamos o aumento da produção de TNF- $\alpha$ nas células $\mathrm{CD}_{11} \mathrm{c}^{+}$cocultivadas com HMC-1.1 previamente tratados com anti-PD-1, nos perguntamos se a interação de iDCs com HMC-1.1 (previamente tratados com anti-PD-1) poderia resultar na diminuição da fosforilação de STAT-3, uma vez que animais que não expressam este fator de transcrição, dentre outras características, produzem grandes quantidades de citocinas inflamatórias (Melillo et al., 2010).

Conforme esperado, nossos resultados indicaram que a frequência de células CD11 $\mathrm{c}^{+}$ também positivas para STAT-3 fosforilado (pSTAT-3) era maior após co-cultivo com HMC1.1, mas este aumento não foi observado quando as HMC-1.1 foram previamente tratadas com anti-PD-1 (Figura 57). 

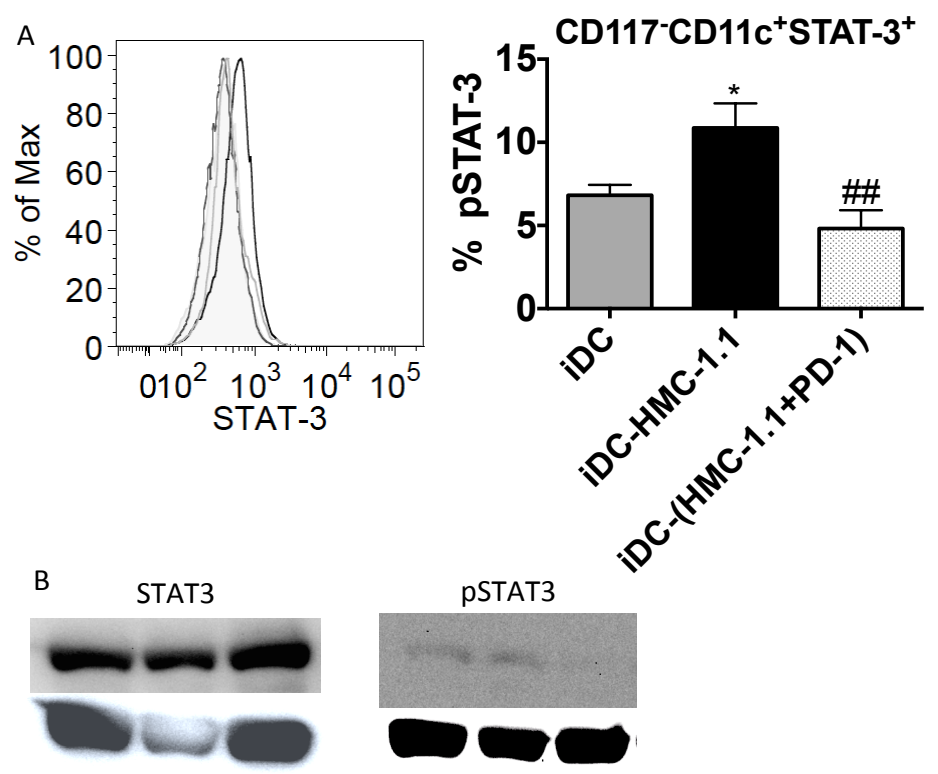

Figura 57. Análise da expressão de STAT-3 nas iDCs co-cultivadas com HMC-1.1. (A) Demonstramos a presença de STAT-3 fosforilado (pSTAT-3) por citometria, para tal, iDCs foram co-cultivadas com HMC-1.1 tratados ou não com anti-PD-1, após $24 \mathrm{~h}$, as células foram permeabilizadas com $90 \%$ de metanol gelado e marcadas com anti-CD117, anti-CD11c e anti-pSTAT-3. À direita, apresentamos a representação gráfica dos resultados obtidos. iDC, $\mathrm{n}=5$; iDC-HMC-1.1, $\mathrm{n}=5$; iDC-(HMC-1.1+PD-1), $\mathrm{n}=5$. Para análise estatística, utilizamos ANOVA seguido por Tukey, em que $\left(^{*}\right)=p<0,05$ e diferente de iDC e $(\# \#)=p<0,01$ e diferente de iDC-HMC-1.1. Em (B), demonstramos uma fotografia referente à presença de STAT-3 total e pSTAT-3 presente nas células $\mathrm{CD} 11 \mathrm{c}^{+}$provenientes dos diferentes grupos experimentais $(\mathrm{n}=1)$.

\subsection{Células tumorais.}

Em outro momento, analisamos se as células da linhagem de CCR humano, HCT-116 poderiam sofrer alguma alteração após o co-cultivo com mastócito. Para tal, HCT-116 foram coradas com CFSE e co-cultivadas com HMC-1.1 ou HMC-1.2 por 24 horas. Após, as células não aderentes foram removidas, a cultura foi lavada com PBS e, por fim, foi adicionado meio de cultura IMDM-10, transcorridas adicionais 24 horas, as células aderentes foram removidas e a diluição do corante (CFSE) foi analisada por citometria de fluxo. Observamos que, quando HCT-116 foram co-cultivadas com HMCS, resultou em maior proliferação de HCT-116, sendo 22,8\% para HMC-1.1 e 37,8 para HMC-1.2, além disso, notamos menor MFI do corante nos grupos citados (Figura 58A e B).

Ainda, dentre as células que eram $\mathrm{CFSE}^{+}$, notamos a expressão de CD117 (c-kit),

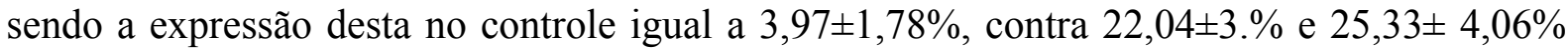
após co-cultivo com HMCs (Figura 58C e D). 

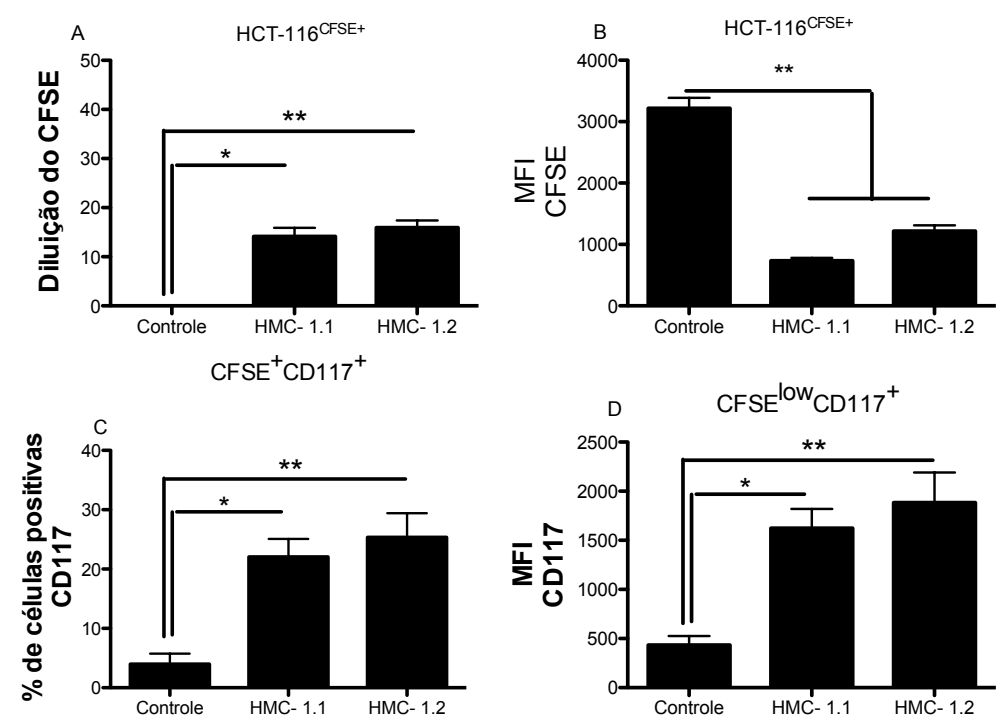

Figura 58. Avaliação da proliferação de HCT-116 após co-cultivo com as linhagens de mastocitoma (HMC-1.1 ou HMC-1.2). Células HCT-116 foram coradas com 5,5 $\mathrm{mM}$ de CFSE e incubadas em estufa a $37^{\circ} \mathrm{C}$ por $4 \mathrm{~h}$, com o intuito de promover a aderência das células. Após este período, as células foram confrontadas com células HMC-1.1 ou HMC-1.2, sendo a proporção respeitada de 10:1, respectivamente. Após 24h, as células não aderentes foram removidas da cultura e as células aderentes remanescentes foram lavadas com PBS $1 \mathrm{x}$ e adicionados $15 \mathrm{~mL}$ de IMDM-10, e mantidas em estufa por $48 \mathrm{~h}$. Depois, as células foram removidas da garrafa e a diluição do CFSE analisada por citometria de fluxo. Em (A), exibimos gráfico representativo da diluição do corante nas células HCT-116 tratadas, ou não, com as linhagens de mastocitoma, (B) Representação gráfica do MFI das células HCT-116 (B), demonstrando que HCT-116 co-cultivadas com mastocitoma parecem ter sua capacidade proliferativa aumentada quando comparada ao controle. (C) Gráfico representativo da expressão da molécula CD117/c-Kit nas células CFSE ${ }^{+}$.

Em outro momento, com o intuito de analisar a importância do contato e aumento da expressão de CD117 nas células tumorais, utilizamos a técnica de transwells, nesta, observamos que somente a linhagem HMC-1.2 foi capaz de induzir a expressão de CD117 por HCT-116 (Figura 59).

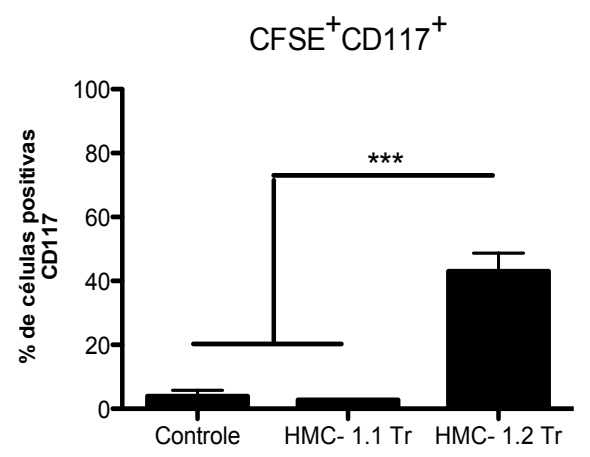

Figura 59. Avaliação da expressão de CD117 na linhagem de CCR (HCT-116), após co-cultura em transwell com mastocitoma. Células HCT-116 foram plaqueadas em placas transwells, após 4 horas, tempo 
necessário para a adesão celular, foram adicionadas células HMC-1.1 ou HMC-1.2 no compartimento superior. Após 48 horas, analisamos a expressão de CD117 nas células HCT-116. Assim, pudemos avaliar a possível capacidade de liberação de vesículas.

Ainda são resultados especulativos e necessitam da análise da expressão de mRNA de c-Kit nas células HCT-116, bem como, análise da troglocitose. 
5 DISCUSSÃO 


\section{DISCUSSÃO}

Devido a sua distribuição, MCs parecem possuir diversas funções tanto em processos fisiológicos quanto patológicos. Por exemplo, devido a sua presença próxima a vasos sanguíneos, linfáticos, células epiteliais e musculares, os mediadores por ele secretados podem influenciar no fluxo, na permeabilidade, na secreção de outros mediadores e na contração muscular em diferentes tecidos. Além disso, MCs parecem estar relacionados em todas as fases de remodelação tecidual após injuria, inflamação aguda e proliferação celular. Sendo que, considerando a fase aguda da inflamação, os MCs parecem influenciar o influxo de células inflamatórias para o tecido afetado, evidenciado pelo menor infiltrado de neutrófilo em tecido inflamado quando os animais eram deficientes em MC (Moon et al., 2010).

Sendo assim, principalmente por este viés inflamatório, estudos recentes indicam uma relação entre o infiltrado de MCs com doenças intestinais inflamatórias (IBD) e a progressão destas para o desenvolvimento de câncer colorretal em humanos e modelos animais, assim como foi descrito em humanos, que a presença de microvesículas e MCs no nicho tumoral resultou em pior prognóstico para este tipo de câncer (Cheon et al., 2011; Gounaris et al., 2007; Gulubova, Vlaykova, 2009; Gulubova et al., 2012; Khazaie et al., 2011; Tunc et al., 2005).

Além disso, recentemente, foi demonstrado que existe um grande infiltrado de células do sistema imune em câncer colorretal (Väyrynen et al., 2013), dentre elas, DCs e MCs (Khan et al., 2013; Khazaie et al., 2011; Suzuki et al., 2002). Isso possibilita, então, a existência de nossa hipótese de que ambas as células podem interagir neste tecido.

Vale notar que, infelizmente, a pesquisa com MCs humanos, até o presente momento, progride lentamente devido, principalmente, a dificuldades para isolá-los de tecido (in vivo) e diferenciá-los in vitro, além do baixo rendimento deste procedimento. Ainda assim, conforme mostrado neste trabalho, nosso grupo foi capaz de diferenciá-los a partir de células CD34 ${ }^{+}$, sendo que observamos expressão das moléculas CD13, c-Kit (SCF-R) e FCERI $\alpha$, estas classicamente relacionadas com o padrão de comprometimento de diferenciação em MCs (Saito et al., 2006; P Welker, Grabbe, Zuberbier, Guhl, Henz, 2000; Pia Welker, Grabbe, Zuberbier, Grützkau, Henz, 2001). Possibilitando, assim, o estudo das consequências da interação entre $\mathrm{MCs}$ e $\mathrm{DCs}$, seja em um contexto com contato celular ou restrito à troca de mediadores solúveis. Interessantemente, dados obtidos em nosso estudo demonstram que DCs 
imaturas (iDCs) quando co-cultivas com MCs em ambos os contextos apresentam diferenças significativas quanto a sua constituição fenotípica, que, possivelmente, refletiu em alterações funcionais. Basicamente, iDCs, quando co-cultivadas com MCs em um sistema monolayer (permitiu o contato entre as células), demonstraram um padrão de expressão mais tolerogênico, evidenciado pela notória diminuição da intensidade de expressão de HLA-DR (molécula pertencente à família do MHC de classe II), CD80 (molécula de co-estímulo positivo) e CD209 (associado à ativação de linfócito). Além disso, observamos uma tendência à diminuição de CD1a (maturação celular), CD83 (maturação celular) e CD40 (molécula de co-estímulo positivo), associada a um aumento na expressão de CD279/ PD-L1 (molécula de co-estímulo negativo). Ao analisarmos o imunofenótipo de iDCs, após co-cultivo de MCTs (MCs previamente expostas a células da linhagem tumoral HCT-116), observa-se que a expressão de PD-L1 se mantém similar ao controle (iDC), no entanto, demonstraram maior frequência de células $\mathrm{CD} 11 \mathrm{c}^{+} \mathrm{PD}-\mathrm{L1}^{+}$; associado à diminuição significativa da expressão de HLA-DR, CD80 e CD209, e à tendência de menor expressão de CD83.

Nesta linha, o infiltrado de DCs com fenótipo CD83 ${ }^{\text {low }}$ e/ou HLA-DR ${ }^{\text {low }}$ foi associado à menor sobrevida de pacientes com câncer colorretal (Gulubova et al., 2012). Logo, considerando nossos resultados quanto ao imunofenótipo de iDCs co-cultivadas com MCT, notamos uma similaridade entre o imunofenótipo observado e o de pior prognóstico. Com isso, nos perguntamos se este fenômeno poderia, também, ocorrer in situ, o que relacionaria a presença de MCs com pior prognóstico.

Outro dado interessante foi o aumento da frequência da molécula CCR7 em iDCs cocultivadas com MCT (citado anteriormente), pois dados presentes na literatura demonstram que a hipertrofia de linfonodos após infecção é dependente do infiltrado de MCs no local da injúria, sendo proposta a produção de TNF- $\alpha$ como fator-chave responsável por este fenômeno (McLachlan et al., 2003; Suto et al., 2006). Nessa linha, Bryce et al. (Bryce et al., 2004) demonstraram que, na pele, a ativação de MCs, mesmo independente da sensibilização por IgE, é essencial para a migração de células de Langerhans. Assim, baseados em nossos resultados, sugerimos que a migração de DCs possa, também, ocorrer via aumento de CCR7 como resposta ao contato com MCs, principalmente, em um contexto tumoral.

Ainda, considerando o aumento da expressão de CCR7, associado ao fenótipo das iDCs após co-cultivo com MCTs, nos questionamos se a exposição das DCs aos MCs poderia induzir a geração de linfócitos T não responsivos ou mesmo reguladores in vivo. Pois, devido 
ao aumento da expressão de CCR7, as DCs poderiam migrar para a zona de linfócitos T, nos órgãos linfoides secundários, no entanto, não seriam capazes de apresentar os antígenos, no caso tumorais, de maneira propícia aos linfócitos T, uma vez que, quando expostas aos MCTs, as DCs exibiram a diminuição das moléculas de co-estímulo (Cools, Ponsaerts, Van Tendeloo, Berneman, 2007; Guermonprez et al., 2002).

Sabe-se que a modulação da resposta imune frente ao balanço da expressão de moléculas de co-estímulo e/ou co-inibitória é de suma importância para a resposta contra tumores, uma vez que estudos recentes indicam que a interação de PD-L1 com linfócito é um fator importante para a indução da tolerância, sendo sua expressão observada em monócitos em regiões peritumorais, e mesmo por células tumorais (Deng et al., 2014; Dong, Chen, 2006; Kuang et al., 2009; Lipson, Vincent, et al., 2013; Thompson et al., 2004). Como prova da importância da interação de PD-L1 com seu ligante, foi proposto como tratamento de alguns tipos de câncer o bloqueio do programador de morte-1 (PD-1), ligante de PD-L1, com anticorpos monoclonais (Callahan, Wolchok, 2013; Dotti, 2009; Harvey, 2014; Lipson, Sharfman, et al., 2013; Taube et al., 2014; Zitvogel, Kroemer, 2012).

Assim, vale enfatizar o aumento da expressão de PD-L1 nos grupos de iDC-MC e o aumento da frequência de células CD11 $\mathrm{c}^{+} \mathrm{PD}-\mathrm{L}^{+}$em iDC-MCT. Pois o aumento desta molécula de estímulo co-inibitório corrobora a nossa hipótese de que o contato de DCs com MCs poderia repercutir em maior indução de tolerância. Uma vez que, embora não completamente elucidado qual o mecanismo responsável pela indução de Tregs, esta pode ser, em partes, resultante da interação de PD-L1 com PD-1, expresso, principalmente, em linfócitos T ativados, uma vez que esta ligação resulta na inibição dos eventos TCR proximais (Chemnitz, Parry, Nichols, June, Riley, 2004); podendo, assim, culminar em apoptose de linfócitos T ativados ou na indução para um perfil regulador destes (Francisco, Sage, Sharpe, 2010). Tal indução, para o perfil de linfócitos Tregs, via PD-L1/PD-1, se torna evidente em transplantes renais, em que células epiteliais do túbulo renal, quando expressavam PD-L1 em sua membrana; resultou no aumento da expressão de FoxP3 nos linfócitos T infiltrantes, bem como menor, rejeição ao órgão transplantado (Keir et al., 2006; Tanaka et al., 2007).

A relação direta entre MCs e tolerância foi evidenciada por Lu et al. em modelos murinos de transplante de pele. No trabalho, os autores observaram uma associação direta entre o infiltrado de MCs e a não rejeição do enxerto; dentre outros fatores, a não rejeição do transplante foi associada a um eixo de MCs e Treg ( $\mathrm{Lu}$ et al., 2006). No entanto, em nosso 
trabalho, não notamos a expressão de moléculas de co-estímulo ou mesmo moléculas coinibitórias (dados não mostrados) por MCs, indicando que a indução de células Treg, possivelmente, não seja uma resposta ao contato de MCs com linfócitos, assim, indicando que possa existir uma célula que interceda a existência deste eixo.

Com o intuito de avaliar se as DCs possuíam o papel "mediador" para a geração de linfócitos Treg, fizeram-se necessários ensaios que demonstrassem a capacidade linfoestimuladora das iDCs. Assim, primeiramente, notamos que tanto iDC-MC quanto iDCMCT não foram capazes de sustentar a proliferação de linfócitos T alogênicos. Paralelamente, não observamos diferença quanto à proporção de linfócitos CD4 e CD8, mas notamos que linfócitos T CD4 expressavam aumento da frequência da molécula CD25 se co-cultivados com MCs, sendo mais notória no grupo iDC-MCT. Isso sugere que estes linfócitos eram capazes de consumir maior quantidade de IL-2, mas tal consumo não refletiu na maior proliferação. Sakagushi et al., em um estudo pioneiro da área, propuseram como uma das características de Tregs o alto consumo desta citocina via CD25, e a não produção desta (Sakaguchi et al., 2005).

Portanto, a baixa proliferação associada ao aumento da expressão de CD25 observada em nosso estudo poderia ser o reflexo de maior indução de linfócitos $\mathrm{T}$ regulatórios pelas iDC-MC e iDC-MCT (L. Wang et al., 2008). Tal hipótese torna-se mais coerente ao analisarmos a expressão de FoxP3; uma vez que linfócitos $\mathrm{CD} 4{ }^{+} \mathrm{CD} 25^{+}$quando co-cultivados com iDC-MC ou iDC-MCT expressavam mais FoxP3 do que o grupo-controle (iDC). Ainda, ao considerarmos o grupo de linfócitos co-cultivados com iDC-MCT, notamos a baixa expressão de CD127, sugerindo que o aumento de FoxP3 não estava associado à maior ativação de linfócitos T (W. Liu et al., 2006).

Assim, sabe-se que o fator de transcrição FoxP3 pode ser expresso de maneira transiente, sendo que, nestas condições, esta expressão não reflete um perfil supressor propriamente dito (J. Wang, Ioan-Facsinay, van der Voort, Huizinga, Toes, 2007). Nestas condições, os linfócitos $\mathrm{T} \mathrm{FoxP}^{+}$não são produtores de citocinas anti-inflamatórias. Em nosso estudo, no entanto, notamos que os linfócitos $\mathrm{T}$ expostos tanto às iDC-MC quanto às iDC-MCT foram capazes de produzir altos níveis de IL-10, indicando que estes linfócitos T $\mathrm{CD} 4{ }^{+} \mathrm{CD} 25^{+}$poderiam, de fato, suprimir a resposta imune. Nesta linha, sabe-se da existência de duas população de linfócitos Treg induzidos perifericamente, Th3 e Tr1; sendo estas diferenciadas pelas citocinas produzidas. Assim, devido à alta produção de IL-10, sugerimos 
que o co-cultivo das iDC-MC ou iDC-MCT induz, preferencialmente, o perfil de células $\operatorname{Tr} 1$. Estas células foram descritas por Groux et al., (Groux et al., 1997), em um modelo murino, em que células T naïve provenientes de animais geneticamente modificado (OVA-TCR), após estímulo constante de OVA e IL-10, passaram a produzir citocinas diferentes dos perfis estabelecidos como Th1 ou Th2. Os autores notaram que os linfócitos produziam grandes concentração de IL-10, pouco IL-5 e IFN- $\gamma$ e médio TGF- $\beta$, estas células foram, então, denominadas como $\operatorname{Tr} 1$. Recentemente, foi comprovado que linfócitos $\mathrm{T}$ humanos também são capazes de se diferenciar em $\operatorname{Tr} 1$ (Bacchetta et al., 2002; Kemper et al., 2003). Os linfócitos Trl parecem exercer um papel fundamental para a tolerância periférica, principalmente, porque são células capazes de suprimir a ativação de linfócitos T naïve e de memória, sendo este papel supressor observado tanto in vitro quanto in vivo (Roncarolo et al., 2001).

Logo, com o intuito de avaliar se os linfócitos T oriundos da co-cultura com iDC-MC ou iDC-MCT exibiam esta função supressora característica de linfócitos $\operatorname{Tr} 1$, avaliamos a capacidade dos linfócitos $\mathrm{CD} 4^{+} \mathrm{CD} 25^{+}$provenientes dos diferentes grupos de co-cultivo, quanto à supressão da proliferação de linfócitos T naïve alogênico ativados por PHA; neste ensaio, notamos que os linfócitos co-cultivados com iDC-MC ou iDC-MCT, conforme esperado, foram capazes de suprimir a proliferação de linfócitos $\mathrm{T}$ nä̈ve estimulados, indicando que, possivelmente, os linfócitos $\mathrm{T}$, de fato, se comprometiam com o perfil regulador/supressor. Isso nos incitou a refletir se tal indução poderia ocorrer também de maneira sistêmica, uma vez que diversos autores relataram o aumento de linfócitos Tregs no sangue periférico e no microambiente de câncer gastrointestinais, ainda, estas células demonstram um papel essencial para a evasão tumoral frente ao sistema imune, resultando, assim, na progressão da doença (Gutkin, Shurin, 2014; Ramos et al., 2013).

Embora, recentemente, o infiltrado de FoxP3 em CCR tenha sido associado ao melhor prognóstico de pacientes (Väyrynen et al., 2013), vale advertir que não foi verificado se as células que expressavam este fator de fato exibiam funções imunossupressoras, impossibilitando, assim, a conclusão de que o infiltrado $\mathrm{FoxP}^{+}$era de células $\mathrm{T}$ regulatórias e não apenas linfócitos T ativados.

Por outro lado, ao analisarmos a porcentagem de citocinas presentes no sobrenadante do co-cultivo de linfócitos com iDC-MC ou iDC-MCT, observamos o aumento significativo de IL-6, uma citocina considerada pró-inflamatória. Assim, embora paradoxal, nos 
questionamos se o aumento de IL-6 observado não poderia ser proveniente da interação de células Tregs (induzidas) com MCs. Uma vez que Bryce e Ganeshan (2012) relataram que a interação direta de MCs com linfócitos Treg resulta no aumento da produção de IL-6 pelas Tregs. Ainda, os autores demonstraram que, nestas condições, a citocina não foi capaz de reverter o perfil regulador para Th17 graças à presença do TGF- $\beta$. Tais resultados estão em concordância com os nossos, pois observamos que os grupos que induziram maior expressão de Treg também demonstraram a presença elevada de TGF- $\beta$, garantindo, assim, a manutenção do perfil regulador, mesmo na presença de IL-6.

Ademais, Blatner et al. demonstraram que o estímulo de IL-6 em células Treg de doadores saudáveis modificou o padrão de produção de IL-10 para IL-17; no entanto, as células não perderam sua capacidade supressora, assim, foram denominadas Tregs alternativas $(\Delta$ Treg), no mesmo trabalho, os pesquisadores mostraram que as células Tregs presentes no sangue periférico de pacientes com CCR demonstravam o perfil semelhante aos linfócitos $\Delta$ Treg. Ainda, os autores demonstraram que MCs presentes no microambiente tumoral possuíam um papel fundamental para a geração de células $\Delta$ Treg (Blatner et al., 2010). De fato, nosso resultados, in vitro, demonstraram que a interação de linfócitos com iDC-MC ou iDC-MCT parece induzir a geração de linfócitos Tr1. Mas, de modo especulativo, nossos dados apontam que o desbalanço de Treg para $\Delta$ Treg possa ocorrer conforme a progressão da doença e o aumento da produção de IL-6 pelos linfócitos Treg induzidos pelas DCs expostas aos MCs, assim, sugerindo a necessidade das DCs para a geração de $\Delta$ Treg.

Em outro momento, considerando a ação das citocinas nas células tumorais, sabe-se que a IL-6 e TNF- $\alpha$ são fatores essenciais para a progresso de pólipos intestinais no desenvolvimento de CCR, bem como, a progressão desta doença. Curiosamente, notamos que, no sobrenadante da co-cultura de linfócitos T alogênicos e iDC-MC ou iDC-MCT, além do aumento da produção de IL-6 descrito, houve o aumento da presença de TNF- $\alpha$; indicando que, indiretamente, a interação de linfócitos T com iDCs expostas aos MCs poderia refletir na progressão da doença.

Outrossim, vale ressaltar a tendência de aumento de IFN- $\gamma$ no sobrenadante das culturas de linfócito T com iDC-MC ou iDC-MCT. Pois, embora a presença desta citocina tenha um viés de ativação do sistema imune inato como ativação de macrófagos, NK e DCs (Vosskuhl, Greten, Manns, Korangy, Wedemeyer, 2010), o aumento de IFN- $\gamma$ pode, também, 
induzir o aumento da expressão de PD-L1 na membrana de DCs (Merlino, Zaidi, 2011). O mecanismo responsável ainda não está completamente esclarecido, mas indica um possível mecanismo de feedback negativo - evidenciado em modelo in vivo de EAE, em que animais deficientes na produção de IFN- $\gamma$ exibem maior sinais de autoimunidade (Wang et al., 2006).

Sendo assim, nos perguntamos, se os fenômenos encontrados poderiam ocorrer devido à produção de mediadores solúveis produzidos por $\mathrm{MCs}$, com o intuito de responder a esta pergunta, as células foram cultivadas em um sistema com restrição ao contato, assim, consideramos apenas o efeito dos mediadores solúveis produzidos pelos MCs sobre as DCs.

Os mediadores produzidos por MCs foram descritos tanto como capazes de inibir a maturação de DCs, como, por exemplo a histamina e metabolitos do ácido araquidônico (Harizi et al., 2002; Martin et al., 2014), quanto capazes de estimular as DCs, tanto aumentando as funções fagocíticas e endocíticas quanto promovendo maior capacidade de ativação linfocitária (Katoh et al., 2005; Mazzoni et al., 2001; Simon et al., 2011; Vanbervliet et al., 2011;Wang, 2014). Ainda, Amaral et al. (2007) demonstraram que a capacidade endocítica observada nas DCs era dependente da ativação via receptor de histamina 2 (H2-R), enquanto após tratamento com antagonista H1-R e H3/4R não foi observado o mesmo fenômeno, indicando que os mediadores produzidos por MCs não podem ser analisados frente ao paradigma: "um mediador, uma resposta" e, sim, necessária análise minuciosa do contexto de receptores e modelos.

Nosso dados apontaram para a linha de ativação de DCs provido pelos mediadores solúveis, uma vez que o co-cultivo tanto de MC quanto de MCT em um sistema transwell (restrito aos mediadores) resultou na maior frequência de CD86 e menor expressão de CD279/PDL1 na membrana de iDCs. O fenômeno de maturação se fez mais evidente ao observamos os dados de MFI, pois observamos maior expressão de HLA-DR, CD209, CD83, CD80, CD86 e CD40, mesmo em relação ao grupo iDC controle. Curiosamente, o aumento de CD86 foi descrito como diretamente dependente do estímulo de histamina (Caron et al., 2001).

Embora os mecanismos pelos quais MCs poderiam modular iDC para a indução da tolerância ainda não foram completamente elucidados; observamos que linfócitos $\mathrm{T}$ cocultivado com iDC-MCs ou iDC-MCT induziram a geração de linfócitos com perfil Tr1, linfócitos produtores de IL-10. No entanto, os grupos experimentais do cultivo em transwells 
não notamos o aumento significativo da expressão de FoxP3 em linfócitos $\mathrm{CD} 4{ }^{+} \mathrm{CD} 25^{+}$, nem a capacidade supressora frente à proliferação de linfócitos T naïve (estimulados com PHA); indicando, assim, que os mediadores produzidos pelos MCs, por si só, não foram suficientes para a indução da tolerância no sistema estudado, mas sim, possivelmente, a combinação destes com o contato celular.

Ainda, considerando as interações celulares, sabe-se que as Treg são capazes de inibir a desgranulação de MCs, principalmente pela interação de OX40 (presente em Treg) com seu ligante expresso por MCs (OX40-L), pois esta ligação resulta no aumento do cAMP intracelular, o que, por consequência, bloqueia o influxo de $\mathrm{Ca}^{+}$necessário para a desgranulação de MC (Gri et al., 2008). Ainda, vale ressaltar que, embora não seja conhecido o mecanismo de ação, notamos que a interação de MCs com iDCs também não resultou na desgranulação de MCs. Assim, baseado em nossos dados e os descritos na literatura, podemos sugerir que a não desgranulação de MCs, resultando na preferência pelo contato celular de MCs com iDC presentes no sítio tumoral, poderia ser um dos motivos pelo estado imaturo de DCs observado no microambiente tumoral (Baleeiro et al., 2008).

Então, considerando dependência do contato para a geração de tDCs, a molécula PD1, expressa em linhagens de mastocitoma humana (LAD) (Kataoka et al., 2013), tornou-se a molécula candidata responsável pela geração de tDCs e/ou manutenção das DCs em um estado imaturo no microambiente tumoral. A expressão de PD-1 por MCs foi, também, observada, em nosso trabalho, em que demonstramos que tanto MCs diferenciados in vitro quanto da linhagem HMC-1.1 expressam PD-1 em sua membrana, e esta expressão não foi cessada após co-cultivo com iDCs (dados não apresentados).

Além disso, no modelo estudado, notamos que a produção de IL-10 pelas DCs não foi determinante para a geração de tDCs, uma vez que não observamos o aumento desta citocina no sobrenadante do co-cultivo de DCs com MCs. Logo, tornou-se interessante a avaliação da produção da enzima indoleamina 2,3-deoxigenase (IDO) pelas células CD11 ${ }^{+}$. Uma vez que o mecanismo de ação da IDO é altamente conservado filogeneticamente e tem seu escopo de ação amplo; a IDO pode ser importante tanto para a resposta contra patógenos extracelulares, pois esta enzima cataboliza aminoácidos essenciais para a sobrevivência do micro-organismo; quanto associada aos mecanismos de imunossupressão, em que diferentes autores sugeriram que esta enzima possui uma potente capacidade supressora da ativação de linfócitos (Holmgaard et al., 2013; Sarkar et al., 2007), principalmente por catabolizar o triptofano, o 
que culmina na inibição da proliferação de linfócitos T efetor (Frumento et al., 2002; Mellor, 2005).

Sendo assim, a IDO, geralmente, se encontra em baixas quantidades em tecidos em homeostase, no entanto, sua produção é, rapidamente, elevada após estímulo por citocinas relacionadas à inflamação. Nesta linha, o aumento da IDO foi descrito como importante para a tolerância materno-fetal, na melhora de doenças autoimune e asma, e para a evasão tumoral frente ao sistema imune (Brandacher et al., 2006; Holmgaard et al., 2013; Zamanakou et al., 2007). Em relação à presença de IDO em tecidos tumorais, Nakamura et al. observaram o aumento desta enzima em tecidos tumorais de colo uterino, sendo que, no trabalho, os autores demonstraram que a produção de IDO era diretamente proporcional ao infiltrado de linfócitos $\mathrm{T} \mathrm{FoxP3}^{+}$(Nakamura et al., 2007), mostrando a relação da IDO com um viés regulador ou supressor.

Logo, a fim de avaliar a relação da interação de DCs com MCs em função da produção de IDO, analisamos, primeiramente, a expressão do gene IDO1, que codifica a IDO de interesse, notamos que, após o co-cultivo com MCs, as iDCs exibiram aumento da expressão do gene, bem como, da produção da enzima, mas esta produção foi dependente da interação de PD-1 expresso pelos MCs; uma vez que esta produção foi cessada quando MCs foram previamente tratados com anti-PD-1. Tal resultado, embora especulativo, pode prover uma possível explicação para os resultados positivos do tratamento por anti-PD-1, mesmo em tumores considerados pouco imunogênicos e refratários para a imunoterapia (Lipson, Sharfman, et al., 2013). Ainda, embora não haja uma diferença significativa entre o bloqueio de PD-L1 e PD-L2, notamos que o bloqueio do segundo ligante parece ser mais potente do que o primeiro. De fato, o estudo da interação de PD-1 expresso por MCs e seus ligantes não foi explorado na literatura, mas sabe-se que o PD-1 expresso em linfócitos $\mathrm{T}$ tem uma afinidade de 2 a 6 vezes maior com PD-L2 do que PD-L1 (Youngnak et al., 2003).

Corroborando com a dependência da interação de PD-1 para a geração de tDCs, iDCs cultivadas com MCs previamente tratados com anti-PD-1, tornam-se produtoras de TNF- $\alpha$, citocina relacionada à maturação/ativação das DCs. Esta capacidade é reduzida tanto em iDCs quanto em iDC-MC. Ainda, observamos que o co-cultivo de iDCs com células HMC-1.1 resultou no aumento de p-STAT-3 nas iDCs, resultado este revertido quando as células HMC1.1 foram tratadas com anti-PD-1. Esta alteração de p-STAT-3 também nos indica a dependência da interação de PD-1 com seus ligantes para a indução ou manutenção das DCs 
em um estado pouco imunogênico. Pois, sabe-se que animais geneticamente modificados para diminuição da expressão de SHP-2 e proteínas quinases ativadas por mitógenos (MAPK) ou ambos (animais gp130 ${ }^{\mathrm{F} 759 / \mathrm{F} 759}$ ), proteínas que, de modo geral, são parte upstream da via de ativação de STAT-3; demonstram esplenomegalia e linfadenopatia precoce (Park et al., 2004). Ainda, em um modelo de nocaute condicionado, em que animais LoxP-Stat-3 foram cruzados com animais transgênicos $\mathrm{CD} 11 \mathrm{c}-\mathrm{Cre}(\mathrm{CKO})$, mostrou-se que animais $\mathrm{CKO}$ possuem 1,5 a 2 vezes mais TNF- $\alpha$ circulante, caquexia e aumento de IFN- $\gamma$, ainda embora não significativo, os autores relataram maior produção de IL-12 e IL-6. Isso indica que a ativação de STAT-3 está associada ao fenótipo de repouso/imaturo das DCs (Melillo et al., 2010).

Por fim, além do papel dos MCs na geração de DCs tolerogênicas, consequentemente, a polarização de linfócitos T para um viés supressor, analisamos, também, o efeito de MCs quanto à produção de citocinas das DCs, surpreendentemente, embora os mediadores solúveis produzidos por MCs não foram capazes de induzir as DCs para um viés tolerogênico, bem como não resultou na indução de Tregs; notamos que iDCs cultivadas com o sobrenadante presente na cultura de MCs apresentaram aumento significativo da produção de IL-10 e uma tendência clara do aumento da secreção IL-6. Ambas as citocinas são relacionadas com a ativação de STAT-3, fator este descrito como constitutivamente ativado nas células de CCR (Lesina et al., 2011; Park et al., 2004). Embora, nossos dados não sejam conclusivos, é atrativo especular a relação entre mediadores de MCs e seus efeitos sobre a função de DC, pois, como citado, ambas as células estão presentes no infiltrado deste tipo de câncer, e, embora relatos, na literatura, indiquem que mediadores lipídicos produzidos por MCs possuem influência sob a progressão tumoral (Khazaie et al., 2011; Sheng et al., 1997). A ativação de STAT-3 de células tumorais (CCR) como resultado da resposta de DCs frente aos mediadores de MCs seria, até o momento, inédita.

De fato, a importância de IL-6 no microambiente tumoral de CCR foi relatada por diversos autores, sendo que Rokavec et al. (Rokavec et al., 2014) observaram um circuito de feedback estabelecido por IL-6/STAT-3, em que a ativação da via resultou na maior expressão de IL-6R. Nesta linha foi observado que o tratamento com embelin, uma droga que inibe a ação da IL-6, culminou na diminuição da colite, bem como, a tumorígenes por ela associada (Dai et al., 2014).

Quanto à IL-10, Braun et al. (Braun, Fribourg, Sealfon, 2013) publicaram que, mesmo 
sendo uma citocina anti-inflamatória, esta é capaz de ativar a via da STAT-3, sendo esta ativação prolongada da via, enquanto a ativação de STAT-3 via IL-6 resultou na ativação aguda. Assim, mesmo contraditório, sugere-se que IL-10 e IL-6 atuam juntas para o aumento da ativação da STAT-3 em células tumorais, paralelamente, promove a evasão tumoral do sistema imune e aumento da inflamação tumoral, respectivamente.

Ainda de maneira especulativa, sabe-se que alguns tumores são capazes de atrair precursores de mastócitos (MCP) da circulação para o nicho tumoral (Huang et al., 2008). Nosso grupo também observou maior migração das linhagens HMC-1.1 e HMC-1.2 em direção de células de linhagens tumorais, sendo elas, HCT-116, H460 e H292 (carcinomas pulmonar humanos), mas não quando o estímulo de migração era I-10 ou linhagem MCR5 (fibroblastos não tumorais) (dados não mostrados). Huang et al. descreveram esta migração como consequência de sinais promovidos por SCF provido pelas células tumorais, no caso, tumor hepático. Além disso, demonstraram que células tumorais eram capazes de se apropriar do CD117/c-Kit expresso por MCs, assim, resultando no crescimento de maneira autócrina/parácrina via este receptor (SCF produzido pelas células tumorais e c-Kit/SCF-R apropriado). Curiosamente, notamos que, após o co-cultivo dos MCs com a linhagem células da linhagem HCT-116, estas mostraram maior taxa de proliferação e entre as células que proliferaram o aparecimento da expressão de CD117 em sua membrana, enquanto, nas condições controles, células HCT-116 não expressam tal marcador.

Portanto, nossos dados suportam a hipótese inicial deste trabalho sobre a capacidade “imunomoduladora” dos MCs quanto à função das DCs. Acreditamos, assim, que os resultados apresentados neste trabalho podem ser relevantes ao que contempla o estudo do microambiente tumoral e de como este pode interferir/modular a resposta antitumoral in vivo. 
6. CONCLUSÃO 


\section{CONCLUSÃO}

$\checkmark$ DCs co-cultivadas com MCs são induzidas para um perfil tolerogênico, não dependente, exclusivamente, de mediadores solúveis.

$\checkmark$ DCs co-cultivadas com MCs em monolayer induzem baixa proliferação de linfócitos T alogênicos;

$\checkmark$ Os MCs não desgranulam quando cultivadas com DCs.

$\checkmark$ O cultivo em transwell, ou seja, restrito aos mediadores solúveis, resulta no imunofenotipo de maior ativação das DCs.

$\checkmark$ O co-cultivo de linfócitos tanto com iDC-MC quanto iDC-MCT resulta no aumento da frequência de células $\mathrm{T}$ FoxP $3^{+}$, produtoras de IL-10 e TGF- $\beta$, e capazes de suprimir a proliferação de linfócitos T nä̈ve.

$\checkmark$ A indução de FoxP3, bem como o perfil tolerogênico das DCs é mais estável no grupo iDC-MCT.

$\checkmark$ MCs diferenciados in vitro e a linhagem HMC-1.1 expressam PD-1 em sua membrana

$\checkmark$ A ligação PD-1 dos MCs com PD-Ls, expressos pelas DCs, parece resultar na amplificação do gene IDO1, bem como a síntese da enzima IDO.

$\checkmark$ O bloqueio de PD-1 expresso em MCs parece induzir o sistema imune para um viés imunogênico de maneira bilateral. Evidenciado pela diminuição da produção de TGF$\beta$ pelos MCs, aumento da produção de TNF- $\alpha$ das DCs e diminuição de pSTAT-3 nas DCs.

$\checkmark$ O co-cultivo de mastócitos com HCT-116 resulta no aumento da proliferação de células HCT-116. 
REFERÊNCIAS 


\section{REFERÊNCIAS*}

As Neves FJ, Mattos IE, Koifman RJ. Colon and rectal cancer mortality in Brazilian capitals. Arquivo de Gastroenterologia. 2005;42(1):63-70.

Amaral, MM, Davio C, Ceballos A, Salamone G, Cañones, C, Geffner, J. Vermeulen, M.Histamine improves antigen uptake and cross-presentation by dendritic cells. Journal of Immunology. 2007;179:3425-33.

Aoki M, Pawankar R, Niimi Y, Kawana, S. Mast cells in basal cell carcinoma express VEGF, IL-8 and RANTES. International Archives of Allergy and Immunology. 2003;130(3):216-23.

Bacchetta R, Sartirana C, Levings MK, Bordignon C, Narula, Roncarolo, MG. Growth and expansion of human $\mathrm{T}$ regulatory type 1 cells are independent from TCR activation but require exogenous cytokines. European Journal of Immunology. 2002;32:2237-45.

Baker RR. Spontaneous regression of bronchogenic carcinoma. National Cancer Institute monograph. 1976;44:31-33.

Baleeiro RB, Anselmo LB, Soares, FA, Pinto CAL, Ramos O, Gross, JL, Barbuto, JAM. High frequency of immature dendritic cells and altered in situ production of interleukin-4 and tumor necrosis factor- $\alpha$ in lung cancer. Cancer Immunology, Immunotherapy. 2008;57:133545 .

Banchereau J, Briere F, Caux C, Davoust J, Lebecque S, Liu Y, Palucka K. Immunobiology of Dendritic Cells. Annual Reviews in Immunology. 2000;18:767-811.

Banchereau J, Schuler-thurner B, Palucka AK, Schuler G. Dendritic Cells as Vectors for Therapy. Current Opinion in Immunology. 2001;25:1-7.

Banchereau J, Steinman RM. Dendritic cells and the control of immunity. Nature. 1998;392(6673):245-52.

Beaven MA. Our perception of the mast cell from Paul Ehrlich to now. European Journal of Immunology. 2009;39:11-25

Benencia F, Sprague L, McGinty J, Pate M, Muccioli, M.. Dendritic cells the tumor microenvironment and the challenges for an effective antitumor vaccination. Journal of Biomedicine \& Biotechnology. 2011;2012:425-76.

Blatner NR, Bonertz A, Beckhove P, Cheon EC, Krantz SB, Strouch M, Khazaie K. In colorectal cancer mast cells contribute to systemic regulatory T-cell dysfunction. Proceedings of the National Academy of Sciences of the United States of America. 2010;107(14):6430-5.

* De acordo com: International Committee of Medical Editors [Internet] requirements for http://www.nlm.nih.gov/bsd/uniform_requirements.htlm 
Bluestone J, Abbas AK. Natural versus adaptive regulatory $\mathrm{T}$ cells. Nature Reviews Immunology. 2003;3(3):253-7.

Brackmann S, Andersen SN, Aamodt G, Langmark F, Clausen OPF, Aadland E, Vatn MH. Relationship between clinical parameters and the colitis-colorectal cancer interval in a cohort of patients with colorectal cancer in inflammatory bowel disease. Scandinavian Journal of Gastroenterology. 2009;44:46-55.

Brandacher G, Perathoner A, Ladurner R, Schneeberger S, Obrist P, Winkler C, Amberger A. Prognostic value of indoleamine 2,3-dioxygenase expression in colorectal cancer: effect on tumor-infiltrating T cells. Clinical Cancer Research: An Official Journal of the American Association for Cancer Research. 2006;12(4):1144-51.

Braun D, Fribourg M, Sealfon SC. Cytokine response is determined by duration of receptor and signal transducers and activators of transcription 3 (STAT3) activation. The Journal of Biological Chemistry. 2013;288:2986-93.

Bryce PJ, Miller ML, Miyajima I, Tsai M, Galli SJ, Oettgen HC. Immune sensitization in the skin is enhanced by antigen-independent effects of IgE. Immunity. 2004;20:381-392.

Bugeon L, Dallman MJ. Costimulation of T Cells. American Journal of Respiratory and critical care. 2000;162:164-168.

Butterfield JH, Weiler D, Dewald G, Gleich GJ. Establishment of an immature mast cell line from a patient with mast cell leukemia. Leukemia Research. 1988;12(4):345-355.

Callahan MK, Wolchok JD. At the bedside: CTLA-4- and PD-1-blocking antibodies in cancer immunotherapy. Journal of Leukocyte Biology. 2013;94:41-53.

Caron G, Delneste Y, Roelandts E, Duez C, Herbault N, Magistrelli G, Jeannin P. Histamine induces CD86 expression and chemokine production by human immature dendritic cells. Journal of Immunology.2001;166:6000-06.

Caux, BC, Massacrier C, Vanbervliet B, Dubois B, Kooten C, Durand I, Banchereau J. Activation of human Dendritic Cells through CD40 Cross-linking,. Journal of Experimental Medicine. 1994;180:1263-1272.

Caux C, Dezutter-Dambuyant C, Schmitt D, Banchereau J. GM-CSF and TNF-alpha cooperate in the generation of dendritic Langerhans cells. Nature. 1992;360:258-61.

Caux C, Massacrier C, Vanbervliet B, Dubois B, Durand I, Cella M, Banchereau J. CD34+ hematopoietic progenitors from human cord blood differentiate along two independent dendritic cell pathways in response to granulocyte-macrophage colony-stimulating factor plus tumor necrosis factor alpha: II. Functional analysis. Blood. 1997;90:1458-70.

Celia BM, Scheidegger D, Palmer-lehmann K, Lane P, Lanzavecchia A, Alber G. Ligation of CD40 on Dendritic Cells Triggers Production of High Levels of Interleukin-12 and Enhances T Cell Stimulatory Capacity: T-T Help via APC activation. Journal of Experimental Medicine. 1996;184:747-52. 
Chan CY, St John AL, Abraham SN. Mast cell interleukin-10 drives localized tolerance in chronic bladder infection. Immunity. 2013;38(2):349-59.

Chemnitz JM, Parry RV, Nichols KE, June CH, Riley JL. SHP-1 and SHP-2 associate with immunoreceptor tyrosine-based switch motif of programmed death 1 upon primary human $\mathrm{T}$ cell stimulation, but only receptor ligation prevents T cell activation. Journal of Immunology. 2004;173:945-54.

Cheon EC, Khazaie K, Khan MW, Strouch MJ, Krantz SB, Phillips J, Bentrem DJ. Mast cell 5-lipoxygenase activity promotes intestinal polyposis in APC $\Delta 468$ mice. Cancer Research. 2011;71:1627-36.

Clatworthy MR, Aronin CEP, Mathews RJ, Morgan NY, Smith KGC, Germain RN. Immune complexes stimulate CCR7-dependent dendritic cell migration to lymph node. Nature Medicine. 2014;1-8.

Collin M, McGovern N, Haniffa M. Human dendritic cell subsets. Immunology. 2013;140(1) :22-30.

Colonna M, Trinchieri G, Liu YJ. Plasmacytoid dendritic cells in immunity. Nature Immunology. 2004;5:1219-1226.

Cools N, Ponsaerts P, Van Tendeloo VFI, Berneman ZN. Balancing between immunity and tolerance: an interplay between dendritic cells, regulatory $\mathrm{T}$ cells, and effector $\mathrm{T}$ cells. Journal of Leukocyte Biology. 2007;82(6):1365-74.

Coussens LM, Werb Z. Inflammation and cancer. Nature. 2002; 420:860-67.

Crivellato E, Nico B, Ribatti D. Mast cells and tumour angiogenesis: new insight from experimental carcinogenesis. Cancer Letters. 2008;269(1):1-6.

Dai Y, Jiao H, Teng G, Wang W, Zhang R, Wang Y, Qiao L. Embelin reduces colitisassociated tumorigenesis through limiting IL-6/STAT3 signaling. Molecular Cancer Therapeutics, 2014.

Deng L, Liang H, Burnette B, Beckett M, Darga T, Weichselbaum RR, Fu Y. Irradiation and anti - PD-L1 treatment synergistically promote antitumor immunity in mice. 2014;124(2): 687-95.

Di Pace RF, Massa S, Ribeiro OG, Cabrera WHK, De Franco M, Starobinas, Ibañez OCM. Inverse genetic predisposition to colon versus lung carcinogenesis in mouse lines selected based on acute inflammatory responsiveness. Carcinogenesis. 2006;27(8):1517-25.

Dong H, Chen X. Immunoregulatory role of B7-H1 in chronicity of inflammatory responses. Cellular \& Molecular Immunology. 2006;3:179-187.

Dotti G. Blocking PD-1 in cancer immunotherapy. Blood. 2009;114:1457-58. 
Dudziak D, Kamphorst AO, Heidkamp GF, Buchholz VR, Trumpfheller C, Yamazaki S, Nussenzweig MC. Differential antigen processing by dendritic cell subsets in vivo. Science. 2007;315:107-11.

Dyduch G, Kaczmarczyk K, Okoń K. Mast cells and cancer: enemies or allies? Polish Journal of Pathology: Official Journal of the Polish Society of Pathologists. 2012;63(1):1-7.

Engels EA, Biggar RJ, Hall HI, Cross H, Crutchfield A, Finch JL, Goedert JJ. Cancer risk in people infected with human immunodeficiency virus in the United States. International Journal of Cancer. Journal International Du Cancer. 2008;123:187-94.

Förster R, Davalos-Misslitz AC, Rot A. CCR7 and its ligands: balancing immunity and tolerance. Nature Reviews Immunology. 2008;8(5):362-71.

Francisco LM, Sage PT, Sharpe AH. The PD-1 pathway in tolerance and autoimmunity. Immunological Reviews. 2010; 238:219-242.

Fricke I, Gabrilovich DI Dendritic cells and tumor microenvironment: a dangerous liaison. Immunol Invest. 2006;35:459-483.

Frumento G, Rotondo R, Tonetti M, Damonte G, Benatti U, Ferrara GB. Tryptophan-derived catabolites are responsible for inhibition of $\mathrm{T}$ and natural killer cell proliferation induced by indoleamine 2,3-dioxygenase. The Journal of Experimental Medicine. 2002;196:459-468.

Ganeshan K, Bryce PJ. Regulatory T cells enhance mast cell production of IL-6 via surfacebound TGF- $\beta$. Journal of Immunology. 2012;188:594-603.

Gilfillan AM, Tkaczyk C. Integrated signalling pathways for mast-cell activation. Nature Reviews Immunology. 2006;218-230.

Gooch JL, Lee aV, Yee D. Interleukin 4 inhibits growth and induces apoptosis in human breast cancer cells. Cancer Research. 1998;58:4199-4205.

Gounaris E, Erdman SE, Restaino C, Gurish MF, Friend DS, Gounari F, Khazaie K. Mast cells are an essential hematopoietic component for polyp development. Proceedings of the National Academy of Sciences of the United States of America. 2007;104(50):19977-82.

Goutagny N, Estornes Y, Hasan U, Lebecque S, Caux C. Targeting pattern recognition receptors in cancer immunotherapy. Targeted Oncology. 2012; 7(1):29-54.

Gri G, Piconese S, Frossi B, Manfroi V, Merluzzi S, Tripodo C, Pucillo CE. CD4+CD25+ regulatory $\mathrm{T}$ cells suppress mast cell degranulation and allergic responses through OX40OX40L interaction. Immunity. 2008; 29(5):771-81.

Grimbaldeston M, Finlay-Jones JJ, Hart PH. Mast cells in photodamaged skin: what is their role in skin cancer? Photochemical \& Photobiological Sciences: Official Journal of the European Photochemistry Association and the European Society for Photobiology. 2006;5(2):177-83. 
Groux H, O’Garra A, Bigler M, Rouleau M, Antonenko S, de Vries JE, Roncarolo MG. A CD4+ T-cell subset inhibits antigen-specific T-cell responses and prevents colitis. Nature. 1997;389:737-742.

Guermonprez P, Amigorena, S. Pathways for antigen cross presentation. Springer Seminars in Immunopathology. 2005;26(3):257-71.

Guermonprez P, Helft J, Claser C, Deroubaix S, Karanje H, Gazumyan A, Nussenzweig MC. Inflammatory Flt31 is essential to mobilize dendritic cells and for $\mathrm{T}$ cell responses during Plasmodium infection. Nature Medicine. 2013;19(6):730-8.

Guermonprez P, Valladeau J, Zitvogel L, Théry C, Amigorena S. Antigen presentation and T cell stimulation by dendritic cells. Annual Review of Immunology. 2002;20:621-67.

Guhl S, Babina M, Neou A, Zuberbier T, Artuc M. Mast cell lines HMC-1 and LAD2 in comparison with mature human skin mast cells--drastically reduced levels of tryptase and chymase in mast cell lines. Experimental Dermatology. 2010;19(9):845-7.

Gulubova M, Vlaykova T. Prognostic significance of mast cell number and microvascular density for the survival of patients with primary colorectal cancer. Journal of Gastroenterology and Hepatology. 2009;24:1265-75.

Gulubova MV, Ananiev JR, Vlaykova TI, Yovchev Y, Tsoneva V, Manolova IM. Role of dendritic cells in progression and clinical outcome of colon cancer. International Journal of Colorectal Disease. 2012;27(2):159-69.

Gutkin DW, Shurin MR. Clinical evaluation of systemic and local immune responses in cancer: time for integration. Cancer Immunology, Immunotherapy. 2014;63(1):45-57.

Hanahan D, Weinberg R.Hallmarks of cancer: the next generation. Cell. 2011;144(5):646-74.

Harizi H, Juzan M, Pitard V, Moreau JF, Gualde N. Cyclooxygenase-2-issued prostaglandin $\mathrm{e}(2)$ enhances the production of endogenous IL-10, which down-regulates dendritic cell functions. Journal of Immunology. 2002;168(5):2255-63.

Harpaz N, Talbot IC. Colorectal cancer in idiopathic inflammatory bowel disease. Seminars in Diagnostic Pathology. 1996;13:339-357.

Harvey RD. Immunologic and Clinical Effects of Targeting PD-1 in Lung Cancer. Clinical Pharmacology and Therapeutics. 2014;96(2).

Heijmans J, Büller NV, Muncan V, van den Brink GR. Role of mast cells in colorectal cancer development, the jury is still out. Biochimica et Biophysica Acta. 2012;1822(1):9-13.

Holmgaard RB, Zamarin D, Munn DH, Wolchok JD, Allison JP. Indoleamine 2,3dioxygenase is a critical resistance mechanism in antitumor $\mathrm{T}$ cell immunotherapy targeting CTLA-4. The Journal of Experimental Medicine. 2013;210(7):1389-402. 
Huang B, Lei Z, Zhang GM, Li D, Song C, Li B, Feng ZH. SCF-mediated mast cell infiltration and activation exacerbate the inflammation and immunosuppression in tumor microenvironment. Blood. 2008;112(4):1269-79.

Jawdat DM, Rowden G, Marshall JS. Mast Cell Have a Pivotal Role in TNF-Independent Lymph Node Hypertrophy and the Mobilization of Langerhans Cells in Response to Bacterial Peptidoglycan. The Journal of Immunology. 2012;177:1755-62.

Jensen BM, Frandsen, PM, Raaby EM, Oluf Schiøtz P, Skov PS, Poulsen LK. Molecular and stimulus-response profiles illustrate heterogeneity between peripheral and cord blood-derived human mast cells. Journal of Leukocyte Biology. 2014;95:1-9.

Jonuleit H, Schmitt E. The Regulatory T Cell Family: Distinct Subsets and their Interrelations. The Journal of Immunology. 2003;171(12):6323-27.

Kataoka TR, Fujimoto M, Moriyoshi K, Koyanagi I, Ueshima C, Kono F, Haga H. PD-1 regulates the growth of human mastocytosis cells. Allergol Int. 2013;62:99-104.

Katoh N, Soga F, Nara T, Masuda K, Kishimoto S. Histamine induces the generation of monocyte-derived dendritic cells that express CD14 but not CD1a. Journal of Investigative Dermatology. 2005;125:753-760.

Keir ME, Liang SC, Guleria I, Latchman YE, Qipo A, Albacker LA, Sharpe AH. Tissue expression of PD-L1 mediates peripheral $\mathrm{T}$ cell tolerance. The Journal of Experimental Medicine. 2006;203:883-895.

Kemper C, Chan AC, Green JM, Brett KA, Murphy KM, Atkinson JP. Activation of human CD4+ cells with CD3 and CD46 induces a T-regulatory cell 1 phenotype. Nature. 2003;421:388-92.

Kerkar SP, Restifo NP. Cellular constituents of immune escape within the tumor microenvironment. Cancer Research. 2012;72(13):3125-30.

Khan MW, Keshavarzian A, Gounaris E, Melson JE, Cheon EC, Blatner NR, Khazaie K. $\mathrm{PI} 3 \mathrm{~K} / \mathrm{AKT}$ signaling is essential for communication between tissue-infiltrating mast cells, macrophages, and epithelial cells in colitis-induced cancer. Clinical Cancer Research. 2013;19:2342-54.

Khazaie K, Blatner NR, Khan MW, Gounari F, Gounaris E, Dennis K, Bentrem DJ. The significant role of mast cells in cancer. Cancer and Metastasis Reviews. 2011;30:45-60.

Klein G, Klein E. Surveillance against tumors--is it mainly immunological?. Immunology Letters. 2005;100:29-33.

Krow-Lucal ER, Kim CC, Burt TD, McCune JM. Distinct functional programming of human fetal and adult monocytes. Blood. 2014;123(12):1897-904.

Kuang DM, Zhao Q, Peng C, Xu J, Zhang JP, Wu C, Zheng L. Activated monocytes in peritumoral stroma of hepatocellular carcinoma foster immune privilege and disease progression through PD-L1. The Journal of Experimental Medicine. 2009;206:1327-1337. 
Lesina M, Kurkowski MU, Ludes K, Rose-John S, Treiber M, Klöppel G, Algül H. Stat3/Socs3 activation by IL-6 transsignaling promotes progression of pancreatic intraepithelial neoplasia and development of pancreatic cancer. Cancer Cell. 2011;19(4):45669.

Lipson EJ, Sharfman WH, Drake CG, Wollner I, Taube JM, Anders R, Topalian SL. Durable cancer regression off-treatment and effective reinduction therapy with an anti-PD-1 antibody,. Clinical Cancer Research: An Official Journal of the American Association for Cancer Research. 2013;19(2):462-8.

Lipson EJ, Vincent JG, Loyo M, Kagohara LT, Luber BS, Wang H, Taube JM. PD-L1 expression in the Merkel cell carcinoma microenvironment: association with inflammation, Merkel cell polyomavirus and overall survival. Cancer Immunology Research. 2013;1(1):5463.

Lisa B, Coussens M, Werb Z. Inflammatory Cells and Cancer: Think Different !. Journal of Experimental Medicine. 2001;193(6):6-9.

Liu J, Zhang Y, Zhao J, Yang Z, Li D, Katirai F, Huang B. Mast cell: insight into remodeling a tumor microenvironment. Cancer Metastasis Reviews. 2011;30(2):177-84.

Liu K, Waskow C, Liu X, Yao K, Hoh J, Nussenzweig M. Origin of dendritic cells in peripheral lymphoid organs of mice. Nature Immunology. 2007;8:578-583.

Liu W, Putnam AL, Xu-Yu Z, Szot GL, Lee MR, Zhu S, Bluestone JA. CD127 expression inversely correlates with FoxP3 and suppressive function of human $\mathrm{CD} 4+\mathrm{T}$ reg cells. The Journal of Experimental Medicine. 2006;203:1701-11.

Lu LF, Lind EF, Gondek DC, Bennett K, Gleeson MW, Pino-Lagos K., Noelle, RJ. Mast cells are essential intermediaries in regulatory T-cell tolerance. Nature. 2006;442: 997-1002.

Lynch, HT, Smyrk TC, Watson P, Lanspa SJ, Lynch JF, Lynch PM, Boland CR. Genetics, natural history, tumor spectrum, and pathology of hereditary nonpolyposis colorectal cancer: an updated review. Gastroenterology. 1993;104:1535-1549.

Maltby S, Khazaie K, McNagny KM. Mast cells in tumor growth: angiogenesis, tissue remodelling and immune-modulation. Biochimica et Biophysica Acta . 2009;1796:19-26.

Martin RK, Saleem, SJ, Folgosa L, Zellner HB, Damle SR., Nguyen GKT, Conrad DH. Mast cell histamine promotes the immunoregulatory activity of myeloid-derived suppressor cells. Journal of Leukocyte Biology. 2014;96:1-9.

Mazzoni A, Young HA, Spitzer JH, Visintin A, Segal DM Histamine regulates cytokine production in maturing dendritic cells, resulting in altered $\mathrm{T}$ cell polarization.The Journal of Clinical Investigation. 2001;108(12):1865-73.

McLachlan JB, Hart JP, Pizzo SV, Shelburne CP, Staats HF, Gunn MD, Abraham SN. Mast cell-derived tumor necrosis factor induces hypertrophy of draining lymph nodes during infection. Nature Immunology. 2003; 4:1199-1205. 
Melillo J, Song L, Bhagat G, Blazquez AB, Plumlee CR, Lee C, Schindler C. Dendritic cell (DC)-specific targeting reveals Stat3 as a negative regulator of DC function. Journal of Immunology. 2010;184(5):2638-2645.

Mellman I, Nussenzweig M. Ralph M. Steinman (1943-2011). Science; 2011.

Mellor A. Indoleamine 2,3 dioxygenase and regulation of $\mathrm{T}$ cell immunity. Biochemical and Biophysical Research Communications. 2005;338:20-24

Miller CJ, Kassem HS, Pepper SD, Hey Y, Ward TH, Margison GP. Mycoplasma infection significantly alters microarray gene expression profiles. BioTechniques. 2003; 35(4):812-814.

Moon TC, St Laurent CD, Morris KE, Marcet C, Yoshimura T, Sekar Y, Befus D. Advances in mast cell biology: new understanding of heterogeneity and function. Mucosal Immunology. 2010;3(2):111-28.

Mosmann TR, Cherwinski H, Bond MW, Giedlin MA, Coffman RL. Two types of murine helper T cell clone. I. Definition according to profiles of lymphokine activities and secreted proteins. Journal of Immunology. 1986;136:2348-2357.

Murdoch C, Muthana M, Coffelt SB, Lewis CE. The role of myeloid cells in the promotion of tumour angiogenesis. Nature Reviews Cancer. 2008;8(8):618-31.

Nakae S, Suto H, Kakurai M, Sedgwick JD, Tsai M, Galli SJ. Mast cells enhance T cell activation: Importance of mast cell-derived TNF. Proceedings of the National Academy of Sciences of the United States of America. 2005;102(18):6467-72.

Nakamura T, Shima T, Saeki A, Hidaka T, Nakashima A, Takikawa O, Saito S Expression of indoleamine 2,3-dioxygenase and the recruitment of Foxp3-expressing regulatory $\mathrm{T}$ cells in the development and progression of uterine cervical cancer. Cancer Science. 2007;98:874881.

Nakayamada S, Takahashi H, Kanno Y, O'Shea JJ. Helper T cell diversity and plasticity, Current Opinion in Immunology. 2012.

Palucka K., Banchereau J. Human dendritic cell subsets in vaccination. Current Opinion in Immunology. 2013;1-7.

Papac RJ. Spontaneous regression of cancer: possible mechanisms. In Vivo. Athens Greece. 1996;12:571-8.

Park SJ, Nakagawa T, Kitamura H, Atsumi T, Kamon H, Sawa S, Hirano T. IL-6 Regulates In Vivo Dendritic Cell Differentiation through STAT3 Activation. The Journal of Immunology. 2004;173(6):3844-54.

Pearce FL. Calcium and mast cell activation. British Journal of Clinical Pharmacology. $1985 ; 2: 267 \mathrm{~S}-74 \mathrm{~S}$. 
Peptides T, Poole TJ, Zetter BR. Stimulation of Rat Peritoneal Mast Cell Migration by Stimulation of Rat Peritoneal Mast Cell Migration by Tumor-derived. Sarcoma. 1983;585761.

Prizment AE, Anderson KE, Visvanathan K, Folsom AR. Inverse association of eosinophil count with colorectal cancer incidence: atherosclerosis risk in communities study. Cancer Epidemiology, Biomarkers \& Prevention: A Publication of the American Association for Cancer Research, Cosponsored by the American Society of Preventive Oncology. 2011; 20(9):1861-4.

Probst HC, McCoy K, Okazaki T, Honjo T, van den Broek M. Resting dendritic cells induce peripheral CD8+ $\mathrm{T}$ cell tolerance through PD-1 and CTLA-4. Nature Immunology. 2005;6(3):280-286.

Quezada S, Peggs KS. Exploiting CTLA-4, PD-1 and PD-L1 to reactivate the host immune response against cancer. British Journal of Cancer. 2013;108(8):1560-5.

Rahir G, Moser M. Tumor microenvironment and lymphocyte infiltration. Cancer Immunology. 2012;61(6):751-9.

Rakoff-nahoum, S. Why Cancer and Inflammation? Yale Journal of Biology and Medicine. 2006;79:123-130.

Ramos RN, de Moraes CJ, Zelante B, Barbuto, JAM. What are the molecules involved in regulatory T-cells induction by dendritic cells in cancer? Clinical \& Developmental Immunology. 2013

Randolph GJ, Angeli V, Swartz M. Dendritic-cell trafficking to lymph nodes through lymphatic vessels. Nature Reviews. Immunology. 2005;5(8):617-28.

Reizis B, Colonna M, Trinchieri G, Barrat F, Gilliet M. Plasmacytoid dendritic cells: onetrick ponies or workhorses of the immune system? Nature Reviews. Immunology. 2011;11:558-65.

Rodriguez Faba O, Palou-Redorta J, Fernández-Gómez JM, Algaba F, Eiró N, Villavicencio H, Vizoso FJ. Matrix Metalloproteinases and Bladder Cancer: What is New? Urology. $2012 ; 581539$.

Rokavec M, Öner MG, Li H, Jackstadt R, Jiang L, Lodygin D, Hermeking H. IL6R/STAT3/miR-34a feedback loop promotes EMT-mediated colorectal cancer invasion and metastasis. The Journal of Clinical Investigation. 2014;124(4):1853-67.

Roncarolo MG, Bacchetta R, Bordignon C, Narula S, Levings MK. Type 1 T regulatory cells. Immunological Reviews. 2001;182: 68-79.

Rowley DA, Fitch FW. The road to the discovery of dendritic cells, a tribute to Ralph Steinman. Cellular Immunology. 2012

Saito H, Kato A, Matsumoto K, Okayama Y. Culture of human mast cells from peripheral blood progenitors. Nature Protocols. 2006;1:2178-83. 
Sallusto BF, Lanzavecchia A. Efficient Presentation of Soluble Antigen by Cultured Human Dendritic Cells Is Maintained by Granulocyte/Macrophage Colony-stimulating Factor Plus Interleukin 4 and Downregulated by Tumor Necrosis Factor alpha. Journal of Experimental Medicine. 1994;179:1109-18.

Samanta A, Li B, Song X, Bembas K, Zhang G, Katsumata M, Greene MI TGF-beta and IL-6 signals modulate chromatin binding and promoter occupancy by acetylated FOXP3. PNAS. 2008;105(37):14023-27.

Sarkar S, Wong R, Hackl SI, Moua O, Gill RG, Wiseman A, Hutton JC. Induction of indoleamine 2,3-dioxygenase by interferon-gamma in human islets. Diabetes. 2007; 56(1):72-9.

Satpathy AT, Wu X, Albring JC, Murphy KM. Re(de)fining the dendritic cell lineage. Nature Immunology. 2012;13(12):1145-54.

Savina A, Amigorena S. Phagocytosis and antigen presentation in dendritic cells. Immunological Reviews. 2007;219:143-56.

Segura E, Amigorena S. Inflammatory dendritic cells in mice and humans. Trends in Immunology. 2013;34(9):440-5.

Segura E, Durand M, Amigorena S. Similar antigen cross-presentation capacity and phagocytic functions in all freshly isolated human lymphoid organ-resident dendritic cells. The Journal of Experimental Medicine. 2013;210(5):1035-47.

Setoguchi R, Hori S, Takahashi T, Sakaguchi S. Homeostatic maintenance of natural Foxp3(+) CD25(+) $\mathrm{CD} 4(+)$ regulatory $\mathrm{T}$ cells by interleukin (IL)-2 and induction of autoimmune disease by IL-2 neutralization. The Journal of Experimental Medicine. 2005; 201(5):723-35.

Shea-Donohue T, Stiltz J, Zhao A, Notari L. Mast cells. Current Gastroenterology Reports. 2010;12(5):349-57.

Sheng H, Shao J, Kirkland SC, Isakson P, Coffey RJ, Morrow J, DuBois RN. Inhibition of human colon cancer cell growth by selective inhibition of cyclooxygenase-2. The Journal of Clinical Investigation. 1997;99:2254-59.

Shortman K, Naik SH. Steady-state and inflammatory dendritic-cell development. Nature Reviews. Immunology. 2007;7(1):19-30.

Simon T, László V, Falus A. Impact of histamine on dendritic cell functions. Cell Biology International. 2011;35(10):997-1000.

Simson L, Ellyard JI, Dent LA., Matthaei KI, Rothenberg ME, Foster PS, Parish CR. Regulation of carcinogenesis by IL-5 and CCL11: a potential role for eosinophils in tumor immune surveillance. Journal of Immunology. 2007;178:4222-29. 
Smith DC, Mcdermott DF, Powderly JD, Carvajal RD, Sosman JA, Atkins MB, Sznol M. Safety, Activity, and Immune Correlates of Anti-PD-1 Antibody in Cancer. New England Journal. 2012;366:2443-54.

Soucek L, Lawlor ER, Soto D, Shchors K, Swigart LB, Evan GI. Mast cells are required for angiogenesis and macroscopic expansion of Myc-induced pancreatic islet tumors. Nature Medicine. 2007;13(10):1211-8.

Steinman RM. Some interfaces of dendritic cell biology. APMIS. 2003;111:675-97.

Steinman RM. Dendritic cells: understanding immunogenicity. European Journal of Immunology. 2007;37Suppl1:S53-60.

Steinman RM, Banchereau J. Taking dendritic cells into medicine. Nature. 2007;449(7161): 419-26.

Steinman RM, Cohn ZA. Identification of a novel cell type in peripheral lymphoid organs of mice. I. Morphology, quantitation, tissue distribution. The Journal of Experimental Medicine. 1973;137:1142-62.

Stoitzner: The Langerhans cell controversy: are they immunostimulatory or immunoregulatory cells of the skin immune system? Immunology and Cell Biology. 2010; 88(4):348-50.

Sun Y, Nelson PS. Molecular pathways: involving microenvironment damage responses in cancer therapy resistance. Clinical Cancer Research: An Official Journal of the American Association for Cancer Research. 2012;18(15):4019-25.

Suto H, Nakae S, Kakurai M, Sedgwick JD, Tsai M, Galli SJ Mast cell-associated TNF promotes dendritic cell migration. Journal of Immunology. 2006;176(7):4102-12.

Suzuki A, Masuda A, Nagata H, Kameoka S, Kikawada Y, Yamakawa M. Mature dendritic cells make clusters with $\mathrm{T}$ cells in the invasive margin of colorectal carcinoma. Journal of Pathology. 2002;196:37-43.

Tanaka K, Albin MJ, Yuan X, Yamaura K, Habicht A, Murayama T, Najafian N. PDL1 is required for peripheral transplantation tolerance and protection from chronic allograft rejection. Journal of Immunology. 2007;179:5204-10.

Taniguchi K, Karin M. Seminars in Immunology IL-6 and related cytokines as the critical lynchpins between inflammation and cancer. Seminars in Immunology. 2014;26(1):54-74.

Taube JM, Klein A, Brahmer JR, Xu H, Pan X, Kim JH, Anders R. Association of PD-1, PD1 Ligands, and Other Features of the Tumor Immune Microenvironment with Response to Anti-PD-1 Therapy. Clinical Cancer Research: An Official Journal of the American Association for Cancer Research. 2014;20:5064-74.

Theoharides TC, Conti P. Mast cells: the Jekyll and Hyde of tumor growth. Trends in Immunology. 2004;25(5):235-41. 
Theoharides TC, Kempuraj D, Tagen M, Conti P, Kalogeromitros D. Differential release of mast cell mediators and the pathogenesis of inflammation. Immunological Reviews. 2007; 217:65-78.

Thompson RH, Gillett MD, Cheville JC, Lohse CM, Dong H, Webster WS, Kwon ED. Costimulatory B7-H1 in renal cell carcinoma patients: Indicator of tumor aggressiveness and potential therapeutic target. Proceedings of the National Academy of Sciences of the United States of America. 2004;101:17174-9.

Toebak MJ, Gibbs S, Bruynzeel DP, Scheper RJ, Rustemeyer T. Dendritic cells: Biology of the skin. Contact Dermatitis. 2009;60:2-20.

Topalian SL, Drake CG, Pardoll DM. Targeting the PD-1/B7-H1(PD-L1) pathway to activate anti-tumor immunity. Current Opinion in Immunology.2012;24(2):207-12.

Tran DQ TGF- beta: the sword, the wane, and the shield of FOXP 3 + regulatory T cells. Journal of Molecular Cell Biology Advances Access. 2011;0:1-9.

Triantafillidis JK, Nasioulas G, Kosmidis PA. Colorectal cancer and inflammatory bowel disease: Epidemiology, risk factors, mechanisms of carcinogenesis and prevention strategies. Anticancer Research. 2009;29:2727-37.

Tunc B, Filik L, Altintaş E, Turhan N, Ulker A, Dağli U. Mucosal mast cells in irritable bowel syndrome and inflammatory bowel disease. Acta Medica / Universitas Carolina, Facultas Medica Hradec Kralove. 2005;48:163-4.

Vanbervliet B, Akdis M, Vocanson M, Rozires A, Benetire J, Rouzaire P, Hennino A. Histamine receptor $\mathrm{H} 1$ signaling on dendritic cells plays a key role in the IFN- $\gamma / \mathrm{IL}-17$ balance in T cell-mediated skin inflammation. Journal of Allergy and Clinical Immunology. 2011; 127.

Väyrynen JP, Tuomisto A, Klintrup K, Mäkelä J, Karttunen TJ, Mäkinen, MJ. Detailed analysis of inflammatory cell infiltration in colorectal cancer. British Journal of Cancer. 2013;109:1839-47.

Verhasselt V, Buelens C, Willems F, De Groote D, Haeffner-Cavaillon N, Goldman M. Bacterial lipopolysaccharide stimulates the production of cytokines and the expression of costimulatory molecules by human peripheral blood dendritic cells: evidence for a soluble CD14-dependent pathway. Journal of Immunology.1997;158:2919-25.

Vicari AP, Caux C, Trinchieri G. Tumour escape from immune surveillance through dendritic cell inactivation. Seminars in Cancer Biology.2002;12(1):33-42.

Vosskuhl K, Greten TF, Manns MP, Korangy F, Wedemeyer J. Lipopolysaccharide-mediated mast cell activation induces IFN-gamma secretion by NK cells. Journal of Immunology. 2010;185:119-125.

Vyas H, Krishnaswamy G. Paul Ehrlich's “Mastzellen”- From Aniline Dyes to DNA Chip Arrays : A Historical Review of Developments in Mast Cell Research. Methods in Molecular Biology. 2005; 315:3-11. 
Wang J, Ioan-Facsinay A, van der Voort EIH, Huizinga TWJ, Toes REM. Transient expression of FOXP3 in human activated nonregulatory CD4+ T cells. European Journal of Immunology. 2007;37:129-138.

Wang L, Pino-Lagos K, de Vries VC, Guleria I, Sayegh MH, Noelle RJ. Programmed death 1 ligand signaling regulates the generation of adaptive Foxp3+CD4+ regulatory $\mathrm{T}$ cells. Proceedings of the National Academy of Sciences of the United States of America. 2008;105:9331-9336.

Wang YMMYC Inhibiting mast cell degranulation by HO-1 affects dendritic cell maturation in vitro. Inflammation Research.2014

Wang Z, Hong J, Sun W, Xu G, Li N, Chen X, Zhang JZ Role of IFN- $\gamma$ in induction of Foxp3 and conversion of $\mathrm{CD} 4+\mathrm{CD} 25-\mathrm{T}$ cells to CD4+ Tregs. Journal of Clinical Investigation.2006;116(9):2434-2441.

Weiner HL Induction and mechanism of action of transforming growth factor-beta-secreting Th3 regulatory cells. Immunological Reviews. 2001;182:207-214.

Welker P, Grabbe J, Zuberbier T, Grützkau A, Henz BM. FceRIa and GM-CSF receptor expression as well as histamine and tryptase levels in cultured human mast cells. Arch. Dermatology. Res. 2001;293:249-258.

Welker P, Grabbe J, Zuberbier T, Guhl S, Henz BM. Mast cell and myeloid marker expression during early in vitro mast cell differentiation from human peripheral blood mononuclear cells. The Journal of Investigative Dermatology.2000;114(1):44-50.

Wikberg ML, Oldenborg P, Palmqvist R. Good guys in colorectal cancer Macrophages. OncoImmunology. 2013;2:2-4.

Yang Z, Zhang B, Li D, Lv M, Huang C, Shen G, Huang, B. Mast cells mobilize myeloidderived suppressor cells and Treg cells in tumor microenvironment via IL-17 pathway in murine hepatocarcinoma model. PloS One. 2010;5(1): e8922.

Youngnak P, Kozono Y, Kozono H, Iwai H, Otsuki N, Jin H, Azuma M. Differential binding properties of B7-H1 and B7-DC to programmed death-1. Biochemical and Biophysical Research Communications. 2003;307(3):672-77.

Zaidi MR, Merlino G. The two faces of interferon-gamma in cancer. Clinical Cancer Research. 2011;17:6118-24.

Zamanakou M, Germenis AE, Karanikas ; Tumor immune escape mediated by indoleamine 2,3-dioxygenase. Immunology Letters.2007;111:69-75.

Zhai RR, Jiang AP, Wang HB, Ma L, Ren XX, Jiang JF, Wang JH. Histamine enhances HIV1-induced modulation of dendritic cells to skew naïve $\mathrm{T}$ cell differentiation toward regulatory T cells. Virology.2013; 442:163-172.

Zhou L, Chong MMW, Littman DR. Plasticity of CD4+ T cell lineage differentiation. Immunity. 2009; 30(5):646-55. 
Zitvogel L, Kroemer G. Targeting PD-1 / PD-L1 interactions for cancer immunotherapy. OncoImmunology. 2012; 1:1223-25. 
Refêrencias 134

\section{$\mathcal{A} \mathcal{N}$ EXOS}




\section{Anexo A: Autorização uso de câmaras de Leucorredução}

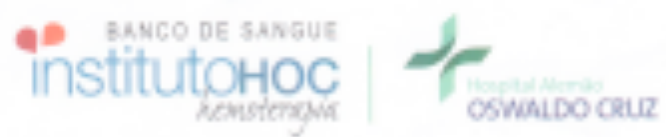

Sto Paula 18 de fevereiro de 2013

\section{AUTORIZACÅ̄O}

Em nome do Instituto HOC de Hemotecapia. autorizo a Sra. Ceclilia Pessos Rodriguesa thlizar as camaras LAS, pecas integranes dos kits descartáveis unlizados para a coleta de plaquetes por afterese leucorreduzidss, em pesquiaa denominada "Avalisça da interazalo entre chlas dendribcas e mastocilce sensbilizedce com celulas tumorais". As referidas camaras contem sangue residual cxm elevada quantidade de leucbcites e sêe removidas do kt imediatamente apds sua uflizaçba, cam o cansentimento escrito do doador de placuetas para a utlizaçso de seu conbeudo em pesquisas institucionais.

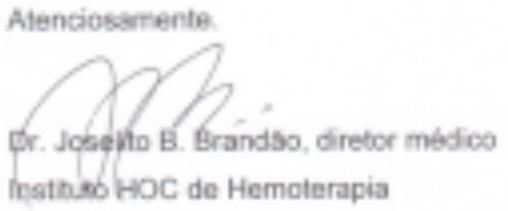

Hospital Alemato Oswalde Cna 
Anexo B. TERMO DE CONSENTIMENTO LIVRE E ESCLARECIDO

Universidade de Săo Paulo

Instituto de Ciênclas Blomédicas

TERMO DE CONSENTIMENTO LIVRE E ESCL_ARECIDO

ESTUDO: INTERAÇŌES ENTRE CÉLULAS DENDRITICAS, MASTÓCITOS E CÉLULAS TUMORAIS

Vace esté sendo convidado (a) a participar do projeto de pesquisa acima citado. 0 documento abaixo contím todes as infarmaçöes necessírias sobre a pesquitsa que estamas farenda. Sua colaboraçấo neste estudo serí de muita impartáncia para mós, mas se destistir a qualquer momento, isso ndo causará nenhum prejuizo a voce.

Bu, residente e domiciliado na

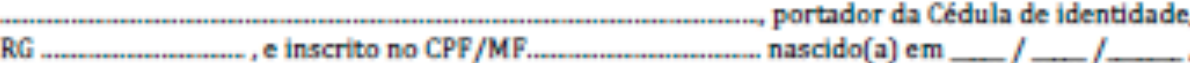
abaixo assinado(a), concordo de livre cespontânea vontade em participar como voluntírio(a) do estudo 'INTERAÇŐES ENTRE CÉLULAS DENDRITICAS, MASTÓCITOS E CÉLULAS TUMORAIS

$\therefore$ Declaro que obtive todas as informaçbes necessárias, bem como todos os eventuais esclarecimentos quanto às dúvidas por mim apresentadas.

Estou ciente que:

1) 0 estudo busca analisar a interaçâo de duas células chamadas células dendríticas e mastócitos, uma vez que estas algumas vezes estio presentes no ambiente tumoral (massa tumoral) produzindo fatores que podem garantir um situactio positiva ao 
crescimento tumoral, no entanto ainda nos restam muitas perguntas sobre essa interaçalo. Portanto, a resposta de algumas perguntas poderá ser usado para aprimorar estratégias de tratamento que procuram provocar respostas do sistema imunolbigico contra células de calncer ("vacinas contra o cincer") e auxilia o entendimento de como o cincer pode manipular nosso sistema de defesa (imunológico):

II) A doaçio da parte do sangue que geralmente é descartada nầo vai alterar, de modo algum, os procedimentos referentes à doação de plaquetas a que me dispus;

III) A participaçio neste projeto nilo tem objetivo de me submeter a um tratamento, bem como năo me acarretará qualquer despesa financeira com relaçlío aos procedimentos médico-clínico-terapéuticos efetuados no estudos

IV) Tenho a liberdade de desistir ou de interromper a colaboraçăo nestr estudo no momento em que desejar, sem necessidade de qualquer explicaçăo;

V) A desistência não causarí nenhum prejuizo à minha saúde ou bem estar fisico. Nĩo virá interferir no atendimento ou tratamento médico;

VI) 0 s resultados obtidos durante este ensaio seräo mantidos em sigilo, mas concordo que sejam divulgados em publicaçöes cientificas, desde que meus dados pessoais não sejam mencionados;

VII) Caso eu desejar, poderei pessoalmente tomar conhecimento dos resultados, ao final desta pesquisa.

( ) Desejo conhecer os resultados desta pesquisa.

( ) Não desejo conhecer os resultados desta pesquisa.

VIII) Concordo que o material possa ser utilizado em outros projetos desde que autorizado pela Comissilo de Etica deste Instituto e pelo responsável por esta pesquisa. Caso minha manifestaçâo seja positiva, poderei retirar essa autorizaçăo a qualquer momento sem qualquer prejuizo para mim.
( ) Sim
ou ( ) Näo

IX) Poderei contatar a Secretaria da Comissio de Etica em Pesquisa com Seres Humanos ICB/USP ?, no Pone 3091.7733 (e-mail: cep@icb.usp.br) ou o responsivel pelo projeto, José Alexandre M. Barbuto, no Fone (11) 3091.7375 (email: jbarbutoe icb.br) para recursos ou reclamaģốes em relaçăo ao presente estuda. Ou poderei contatar a Secretaria da Comissilo de ética em Pesquisa com Seres Humanos - HOC/ SP, no Fone (11)

3549.0423, sendo o coordenador responstivel Dr. José Mario Neves Jorge. 
X) O sujeito de pesquisa ou seu representante, quando for o caso, deverá rubricar todas as folhas do Termo de Consentimento Livre e Esclarecido - TCLE - apondo sua assinatura na última página do referido Terma.

XI) 0 pesquisador responsivel deveri da mesma forma, rubricar todas as folhas do Termo de Consentimento Livre e Esclarecido - TCL.E- apondo sua assinatura na última página do referido Terma

XII) Resoluçio 196/96 - Estou recebendo uma cópia deste Termo de Consentimento Livre e Esclarecido.
Sio Paula,
de
de 20 .

( ) Pacientr / ( ) Responsável

Testemunha 1:

Nome / RG / Telefone

Testemunha 2:

Nome / RG / Telefone

Responsaivel pelo Projeto:

Dr. JOSE ALEXANDRE MARZAGÃo BARBUTO

CRM: 41567 
Anexo C. Lista dos anticorpos, flurocromos e clones utilizados no estudo

\begin{tabular}{|c|c|c|}
\hline & Fluorocromo & Clone \\
\hline \multicolumn{3}{|c|}{ Extracelular } \\
\hline CD1a & FITC & HI149 \\
\hline CD3 & $\overline{A P C}$ & HIT3a \\
\hline CD4 & $\mathrm{PE}$ & RPA-T4 \\
\hline CD8 & PERCP & SK1 \\
\hline CD11c & $\mathrm{V450}$ & B-ly6 \\
\hline CD11c & $\mathrm{APC}$ & B-ly6 \\
\hline CD11c & $\mathrm{PE}$ & B-ly6 \\
\hline CD13 & $\mathrm{PE}$ & L138 \\
\hline CD14 & $\mathrm{APCCy} 7$ & MphiPg \\
\hline $\mathrm{CD} 25$ & FITC & $M-A 251$ \\
\hline $\mathrm{CD} 25$ & $\mathrm{PeCy} 7$ & M-A251 \\
\hline CD40 & $\mathrm{APCCy} 7$ & $\mathrm{SC}_{3}$ \\
\hline CDBD & $\mathrm{PE}$ & L307.4 \\
\hline CDB3 & APC & HB15e \\
\hline CDB6 & PECy 5 & 2331 (FUN-1) \\
\hline CD107a & PE & $\mathrm{H} 4 \mathrm{~A} 3$ \\
\hline CD117 & PECy 7 & $104 D 2$ \\
\hline CD117 & V450 & $104 \mathrm{D} 2$ \\
\hline CD127 & PERCPCy 5.5 & HIL-7RM21 \\
\hline CD197/CCR7 & $\mathrm{PeCy} 7$ & $3 \mathrm{D} 12$ \\
\hline CD209 & FITC & DCN46 \\
\hline CD273/PDL2 & $\mathrm{APC}$ & $\mathrm{MIH18}$ \\
\hline CD274/PDL1 & $\mathrm{PE}$ & $\mathrm{MIH1}$ \\
\hline CD279/PD-1 & $\overline{\mathrm{APC}}$ & $\mathrm{MIH}-4$ \\
\hline HLA-DR & V500 & $646-6$ \\
\hline FCeRla & FITC & AER-37 (CRA-1) \\
\hline \multicolumn{3}{|c|}{ Intracelular } \\
\hline FoxP3 & $\mathrm{PE}$ & 236AVE7 \\
\hline $\mathrm{IL}-12 \mathrm{p} 70$ & $\mathrm{PE}$ & $20 \mathrm{C} 2$ \\
\hline STAT-3 & \begin{tabular}{|l|} 
AlexaFluor 488 \\
\end{tabular} & 4Q/pSTAT-3 \\
\hline STAT-6 & APC? & \\
\hline TGF-beta & PERCPCy 5.5 & $04: 46$ \\
\hline TNF-alpha & FITC & Mab11 \\
\hline & & \\
\hline
\end{tabular}

